Universidade de São Paulo
Faculdade de Filosofia, Letras e Ciências Humanas

\title{
O discurso da memória Entre o sensível e o inteligível
}

Mariana Luz Pessoa de Barros

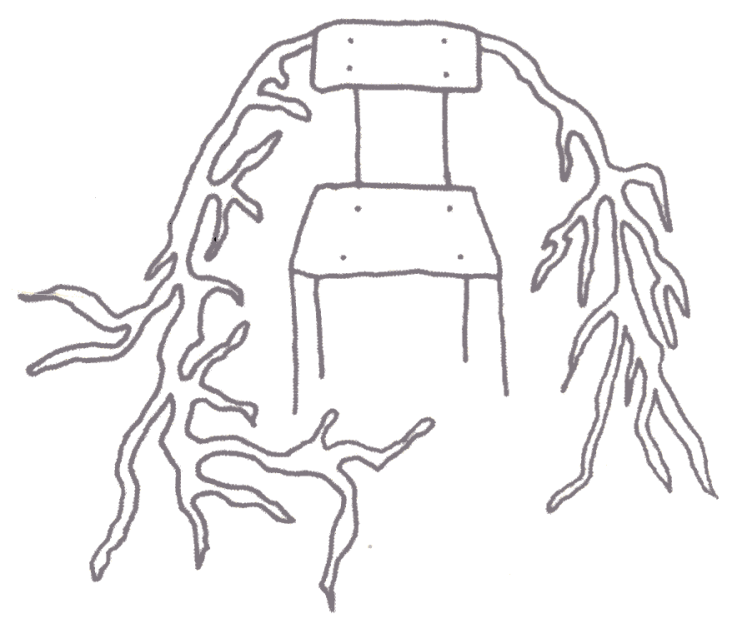

São Paulo

2011

Versão Corrigida 
Universidade de São Paulo

Faculdade de Filosofia, Letras e Ciências Humanas

Departamento de Linguística

\section{O DISCURSO DA MEMÓRIA}

\section{ENTRE O SENSÍVEL E O INTELIGÍVEL}

Mariana Luz Pessoa de Barros maluzpessoa@hotmail.com

Tese de Doutorado apresentada ao Programa de Pós-Graduação em Semiótica e Linguística Geral do Departamento de Linguística da Faculdade de Filosofia, Letras e Ciências Humanas da Universidade de São Paulo, para a obtenção do título de Doutor em Linguística.

Orientador: Profa. Dra Norma Discini de Campos

São Paulo

2011

Versão Corrigida

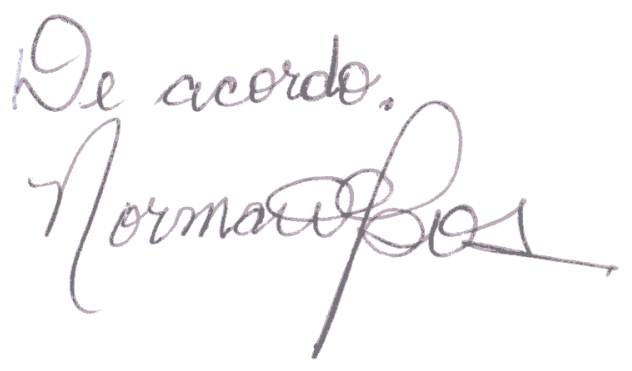

SBD-FFLCH-USP

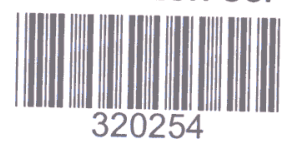




\author{
Universidade de São Paulo \\ Faculdade de Filosofia, Letras e Ciências Humanas \\ Departamento de Linguística
}

\title{
O DISCURSO DA MEMÓRIA \\ ENTRE O SENSÍVEL E O INTELIGÍVEL
}

Mariana Luz Pessoa de Barros

maluzpessoa@hotmail.com

Tese de Doutorado apresentada ao Programa de Pós-Graduação em Semiótica e Linguística Geral do Departamento de Linguística da Faculdade de Filosofia, Letras e Ciências Humanas da Universidade de São Paulo, para a obtenção do título de Doutor em Linguística.

Orientador: Prof ${ }^{a}$. Dr ${ }^{\mathrm{a}}$ Norma Discini de Campos

São Paulo

2011 
Para o Danilo, na Amazônia e sempre aqui. 


\section{AGRADECIMENTOS}

À professora Norma Discini de Campos, que me guiou com carinho, muito entusiasmo, sabedoria e rigor.

Ao professor José Luiz Fiorin, meu primeiro orientador, pelo apoio afetuoso, pelas inúmeras contribuições desde o mestrado e pela leitura cuidadosa, como sempre, do relatório de qualificação.

Ao professor Luiz Tatit, pelos cursos inspiradores e pelas excelentes sugestões no exame de qualificação.

Ao professor Denis Bertrand, que me acolheu tão bem em Paris e deu grandes contribuições ao trabalho.

Aos professores Ivã Carlos Lopes, Waldir Beividas, Antonio Vicente Pietroforte, Lucia Teixeira, Beth Harkot-de-la-Taille, Sémir Badir, Éric Landowski e Claude Zilberberg que em cursos, congressos, comunicações, conferências, reuniões contribuíram para o desenvolvimento desta pesquisa.

Aos professores do Departamento de Linguística e, em especial, aos professores Marcos Lopes, Esmeralda Negrão e Evani Viotti, grandes incentivadores.

Aos funcionários do Departamento de Linguística, Érica, Beh-Hur e Robson, por toda a assistência

Aos meus pais, Diana e Hyeróclio, pelo apoio incondicional de todas as horas, pelo afeto, pelas ajudas inúmeras, enfim, por tudo e ainda mais alguma coisa.

À minha irmã, Flávia, sempre interrompendo o meu trabalho com bolos e cafés. Ainda bem, a vida fica melhor assim!

À Lu, minha avó, pelo carinho de sempre.

Aos meus familiares, Murilo, Dario, Lucia, Regina, Gabi, Gui, Lícia, Henrique, Thyciara, pelos jantares "de quarta". Isso também ajuda!

À Lúcia, mãe do Danilo, que, além disso, ainda fez a tradução do resumo. 
Aos amigos queridos (Carô, Lucia, Fábio, Flávia, Manu, Lucimara, Paulo, Dri, Alê, Maíra, Camila, Martine, Pierre, Ramiro, Fred e tantos outros), pelo amparo, pela afeição.

Aos amigos semioticistas e também queridos, Carol Lemos, Kiko, Carol Tomasi, Ju Pondian, pela interlocução sensível e inteligível.

Ao pessoal do Grupo de Estudos Semióticos da USP e, em especial, ao Alexandre, à Bruna e à Dayane, pelos aprendizados partilhados.

Aos colegas do grupo Clássicos da Linguística, pelos debates calorosos que, certamente, estão refletidos neste trabalho.

Ao CNPq, pela bolsa concedida a esta pesquisa.

À CAPES, pela bolsa de doutorado-sanduíche. 


\section{REsUMO}

Com base na teoria semiótica greimasiana e em seus desdobramentos na gramática tensiva, são analisados diferentes gêneros autobiográficos produzidos no Brasil, como a autobiografia literária em prosa, os poemas de caráter autobiográfico e os memoriais acadêmicos. Um dos objetivos deste trabalho é examinar a construção desses gêneros em relação com as esferas da comunicação de que participam: a esfera literária e a esfera acadêmica. Além disso, são analisadas as formas de adesão do enunciatário aos discursos, uma vez que, em cada gênero e mesmo em cada texto, o enunciador, ao apresentar retrospectivamente a sua vida, regulamenta de forma singular a entrada de grandezas no campo de presença do enunciatário. A análise do corpus permite propor duas formas discursivas de memória como categoria analítica dos discursos autobiográficos: a memória do acontecido e a memória-acontecimento. Mais da ordem do inteligível, a primeira manipula o enunciatário por meio de estratégias que privilegiam a legibilidade do texto, enquanto a segunda promove uma experiência, predominantemente, sensível. Os diversos gêneros que compõem o corpus desta pesquisa tendem a favorecer uma combinação específica entre essas duas formas da memória. Isso possibilita que eles sejam organizados num gradiente, que tem num dos extremos os memoriais acadêmicos e, no outro, os poemas de caráter autobiográfico. As autobiografias literárias em prosa se encontram entre as duas pontas, ora tendendo para um, ora para outro extremo.

PALAVRAS-CHAVE: memória; semiótica; acontecimento; gênero; enunciação; discurso autobiográfico. 


\section{ABSTRACT}

Based on the French Semiotics theory and its segments in the tensive Grammar, this study analyses different sorts of autobiographical genres written in Brazil, such as the literary autobiographies in prose, autobiographical poems and academic autobiographies. One of the aims of this study is to examine the building up process of these genres and how they relate with the communication spheres they participate in: the literary sphere and the academic sphere. Moreover, as the enunciator uniquely regulates the introduction of objects in the enunciatee's presence field while recollecting past moments of his life, this study also analyses the different ways how the enunciatee adheres to the discourses in each genre and even in each text. The analysis of the corpus allows this study to propose two discursive types of memory as an analytical category: the memory of past event and the event memory. Being more intelligible, the former captures the enunciatee through strategies which highlight the legibility of the text, whereas the latter promotes an essentially sensitive experience. The different genres which compose the corpus of this research contribute to a particular combination between these two types of memory. Such combination leads to the organization of the autobiographical genres in a gradient which presents the academic autobiographies at one end and the autobiographical poems at the other. The literary autobiographies in prose lie between both ends, tending alternatively to one or another end.

KEYWORDS: memory; semiotics, event; genre; enunciation; autobiographical discourse. 


\section{SUMÁRIO}

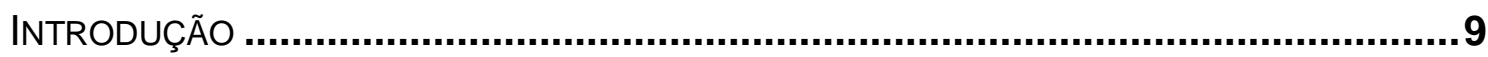

CAPÍTULO 1 - A AUTOBIOGRAFIA LITERÁRIA EM PROSA: A CRIAÇÃO DO PASSADO .......22

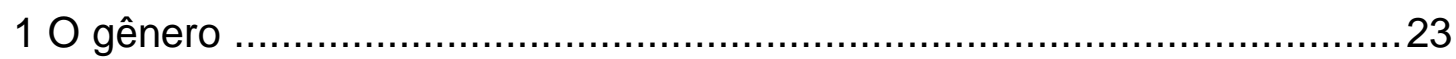

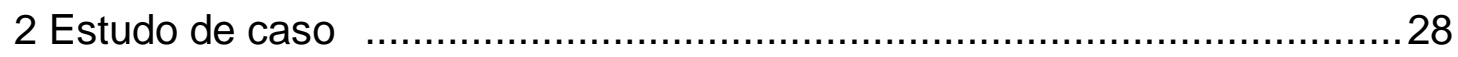

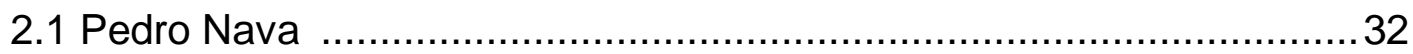

2. 1.1 As três identidades do discurso autobiográfico: uma comparação

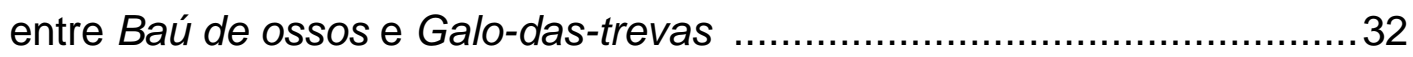

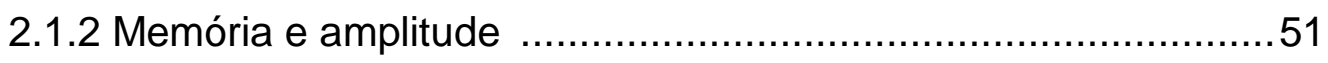

2.1.3 Sobre a saudade e o ressentimento ……………..................

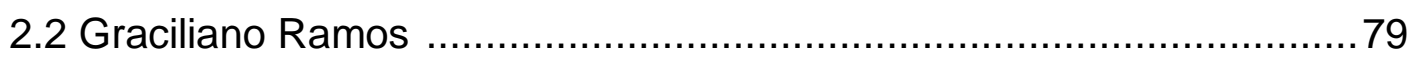

2.2.1 Infância: memória e fragmentação …………….......................79

3 Considerações finais: a prosa literária autobiográfica .............................86

CAPÍTULO 2 - PoESIA: MEMÓRIA E PRESENÇA EM MANUEL BANDEIRA ....................94

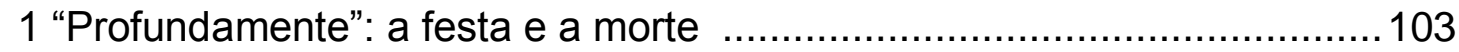

2 "Evocação do Recife": o fluxo das lembranças ......................................111

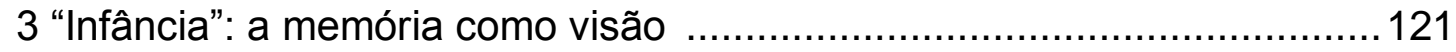

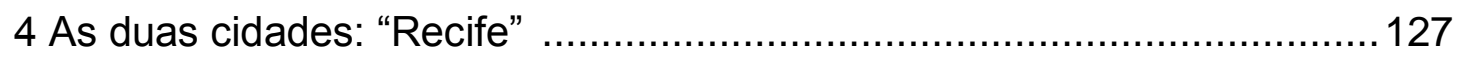

5 Considerações finais: os poemas autobiográficos ...............................137

CAPÍTULO 3 - O MEMORIAL ACADÊMICO: A IMAGEM DO PROFESSOR-PESQUISADOR 155

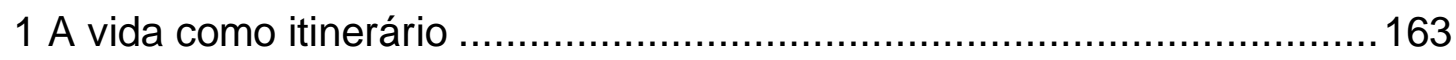

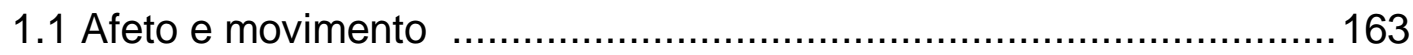

1.2 A ciência e a memória ……………........................................... 178

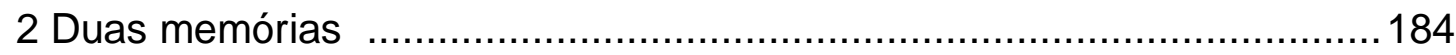

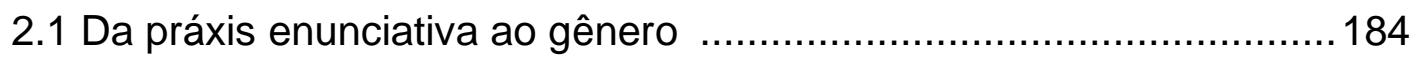

2.20 éthos do memorialista: "aprovado com distinção e louvor" ............202

3 Considerações finais: o memorial acadêmico ......................................232 
CAPÍTULO 4 - ENTRE MEMÓRIAS E GÊNEROS

1Os níveis do discurso autobiográfico 239

2 Identidade: uma questão de graus.............................................243

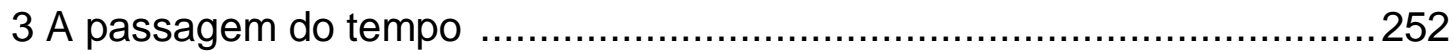

4 A memória-acontecimento e a memória do acontecido ..........................266

5 Considerações finais: a relação entre o enunciador e o enunciatário no discurso autobiográfico 288

CONCLUSÃO 290

BIBLIOGRAFIA 298 


\section{INTRODUÇÃO}

Inventei um menino levado da breca para me ser.

Ele tinha um gosto elevado para chão

De seu olhar vazava uma nobreza de árvore.

Tinha desapetite para obedecer a arrumação das coisas

Manoel de Barros

Memórias inventadas

As Memórias inventadas: a terceira infância (2008, I), de Manoel de Barros, apresentam como "os doadores de suas fontes": os "pássaros", por propiciarem o aprendizado dos "despreendimentos das coisas da terra"; os "andarilhos", por fazerem uso da ignorância, e a criança que "me escreve". O sujeito que se recorda de seu passado não quer colocar "data em sua existência", prefere antes "encher o tempo": "Nossa data maior era o quando [...] Tem hora que eu sou quando uma pedra" (BARROS, 2007, XV). A ressignificação da língua é festejada nessa obra, assim como todas as possibilidades dadas pela imaginação.

Que concepção de escritura autobiográfica podemos depreender de uma obra em que se afirma "Tudo o que não invento é falso"? Com certeza não é a mesma da que se revela em Memórias (1947), de Humberto Campos, livro cujo narrador diz preferir "confessar a ignorância a recorrer à fantasia" (p. 11), quando se propõe a discorrer sobre suas origens. Desde o "Prefácio", suas páginas estão repletas de certezas, de asserções:

Escrevo a história da minha vida não porque se trate de mim; mas porque constitui uma lição de coragem aos tímidos, de audácia aos pobres, de esperança aos desenganados, e, dessa maneira, um roteiro útil à mocidade que a manuseie. Os vícios que a afeiam, os erros que a singularizam e que proclamo com inteira tranquilidade de alma, os rochedos, em suma, em que bati, mesmo esses me foram proveitosos, e sê-lo-ão, talvez, aos que lerem. Conhecendo-os, saberão aqueles que vierem depois de mim, que devem evitá-los, fugindo aos perigos que enfrentei, e, conseguintemente, procurando na viagem, caminhos mais limpos e seguros (CAMPOS, 1947, p. 8-9). 
Se a obra de Manoel de Barros focaliza as miudezas - os "pardais", as "rãs", as "coisinhas seráficas", o "regador", as "brancas bostas" das garças -, a de Humberto Campos conta a história dos grandes feitos de um homem que, indo contra o destino que acreditava lhe caber, chega a ocupar "uma poltrona de Academia e uma cadeira de Parlamento" (1947, p. 8).

Em obras separadas por mais de meio século, a própria memória, com suas faculdades de esquecer e lembrar, parece não ser compreendida de forma semelhante. Em Manoel de Barros, a memória aparece associada à "invenção", à "imaginação", à "descoberta”, sendo marcada pela incoatividade ela é o começo de alguma coisa - , em Humberto Campos, ela é o ponto de chegada, o "baú" de onde são retirados os fatos importantes, como eles foram - e não como são -, e que devem sobreviver à morte do autor e fazer seu nome perdurar: "Que pretendo eu, em verdade, ao idear uma obra vasta, uma bibliografia numerosa? Pretendo, apenas, que meu nome me sobreviva, que se fale de mim quando eu já repousar no seio da terra" (1947, p. 7-8). Algumas vezes, o narrador até confessa que, apesar de sua sinceridade, é possível que a memória altere certos eventos lembrados, mas isso apenas atribui maior credibilidade ao restante do texto.

Podemos, a partir da concepção de memória veiculada em cada texto, perguntarmo-nos que verdade cada um deles constrói, pois a memória pode ser apresentada dominantemente como retrato fiel do passado ou como criação. Talvez decorra daí o interesse pelo exame das relações entre "ficção" e "realidade" que se pode notar nos diversos estudos da literatura autobiográfica.

Para Galle e Olmos, as incertezas que rondam o gênero autobiográfico parecem ser uma marca do século XX:

[...] no século $X X$, as certezas nas quais as autobiografias se fundavam, a saber, a concepção positiva de um "eu" consciente de si, a configuração da experiência de vida como uma unidade coesa e a confiança inabalável na língua como veículo de representação, começaram a desmoronar (2009, p. 10). 
Dessas observações iniciais, nasce um primeiro interesse deste trabalho de tratar não mais das relações entre "ficção" e "realidade", numa perspectiva referencial, mas do contrato de veridicção que se estabelece entre enunciador e enunciatário, tal como entendido pela semiótica.

A peculiaridade da semiótica greimasiana no tratamento dado ao discurso autobiográfico está na possibilidade de deslocar um pouco as questões brevemente esboçadas, passando da ordem do ser à da relação entre o ser e o parecer. Assim, é possível deixar de lado a busca por definir se as cenas autobiográficas criadas em cada enunciado são reais ou ficcionais e passar à tentativa de entender os efeitos de verdade propostos pelos discursos a seus leitores, e também como a arquitetura memorialística os atinge e os afeta.

Para a semiótica, a enunciação é sempre pressuposta. Tal concepção da enunciação exclui de seu âmbito de pertinência a pessoa de carne e osso e não caracteriza os discursos de acordo com o seu referente externo, mas a partir de um contrato fiduciário firmado pelos parceiros da comunicação, o enunciador e o enunciatário, que determina o estatuto veridictório do discurso. Esse posicionamento funda-se na compreensão da "[...] participação da língua na construção do mundo dos objetos, e da relatividade, correspondente à diversidade das sociedades humanas, do recorte do mundo das significações" (GREIMAS, 1970, p. 51; tradução nossa) ${ }^{1}$. Assim, a definição de um discurso como autobiográfico passa pelo exame dos efeitos de sentido ou simulacros criados na própria imanência discursiva.

Esses efeitos estão vinculados aos gêneros, que estabelecem formas relativamente estáveis para sua produção, dentro de uma cultura e de um período determinados. Assim, a semiótica entenderá os textos autobiográficos como um discurso que não designa a pessoa efetiva, mas produz um simulacro do escritor no interior da obra. Conforme afirma Bakhtin:

Mesmo se ele (autor) escrevesse uma autobiografia ou a mais verídica das confissões, como seu criador, ele igualmente permanecerá fora do mundo representado. Se eu narrar (escrever) um fato que acaba de

1 “[...] participation de la langue à la construction du monde des objets, et de la relativité, correspondant à la diversité des sociétés humaines, du découpage du monde des significations". 
acontecer comigo, já me encontro, como narrador (ou escritor), fora do tempo-espaço onde o evento se realizou. É tão impossível a identificação absoluta do meu "eu" com o "eu" de que falo, como suspender a si mesmo pelos cabelos (1998, p. 360).

Não se trata de negar a realidade, pois, conforme afirmam Beividas e Ravanello: "A linguagem ou o discurso não cria o mundo ex nihilo, mas uma vez em cena, o mundo está recriado à sua imagem e estrutura" (2006, p. 15). Além disso, não se trata de negar a história. Pelo contrário, a imanência constrói em si a transcendência social e histórica. Segundo Bertrand (2003a, p. 406), é justamente por considerar que as formas de ajuste entre as semióticas do mundo natural ${ }^{2}$ e as manifestações discursivas não são fixas, mas culturalmente marcadas pelo uso, que a teoria semiótica não classifica os textos de acordo com o seu "referente", opondo os que teriam "referentes imaginários" àqueles que teriam "um referente real".

Ao herdar a noção saussuriana de signo e ainda de valor, a semiótica descola a linguagem de qualquer "naturalização", libertando-a justamente para a história ${ }^{3}$. Como mostra Discini:

A noção de valor também ampara a ideia de sistemas de crenças sociais. As representações simbólicas obedecem a um sistema que as rege, logo não se pode supor que sejam dadas aleatoriamente. Elas se organizam segundo certa formação ou rede estrutural. A estrutura não é a-histórica, e pensar isso acaba por clarear a própria noção de formações discursivas, que subsidiam os temas e figuras do discurso. A assunção de valores ideológicos pela enunciação reverbera na axiologia estabelecida no nível fundamental, e, sendo a recíproca verdadeira, todos os patamares da construção do sentido esboçam certo lugar que o sujeito ocupa no mundo (2009, p. 598).

Por conseguinte, as relações entre enunciador e enunciatário são pensadas, na semiótica, a partir da noção de contrato e mais especificamente de contrato veridictório ou enunciativo. Para Greimas e Courtés (2008), a problemática da verdade pode ser interpretada como a inscrição e, assim, a

2 Greimas (1970) define o "mundo natural" como uma semiótica e propõe considerar as relações entre os sistemas linguísticos e os sistemas de significação do mundo natural, não como uma referência do simbólico ao natural, mas como uma rede de correlações de dois níveis de realidade significante para o homem.

${ }^{3}$ Para Saussure (1969), só existem diferenças na língua. A significação é dada pelo valor, ou seja, pelo conjunto de diferenças que faz um signo ser o que os outros não são. 
leitura das marcas que fazem um discurso-enunciado se apresentar como verdadeiro ou falso, mentiroso ou secreto. Entretanto, conforme evidenciam os autores, esses dispositivos não garantem a construção da verdade, que depende de mecanismos epistêmicos presentes nas duas extremidades da comunicação, nas instâncias do enunciador e do enunciatário: "um crerverdadeiro deve ser instalado nas duas extremidades do canal de comunicação, e é esse equilíbrio, mais ou menos estável, esse entendimento tácito entre dois cúmplices mais ou menos conscientes que nós denominamos contrato de veridicção"( p. 530).

Greimas inicia "Le contrat de véridiction" (1983, p. 103-113) dizendo que os modos de leitura de um texto estão condicionados às variações históricas dos contextos socioculturais. Para exemplificar tal afirmação, recupera as reflexões de $\mathrm{Y}$. Lotman sobre textos recebidos como religiosos na Idade Média e que passaram a ser lidos como literários alguns séculos depois. No entanto, o autor enfatiza que, embora um texto possua múltiplas isotopias de leitura, ele não aceita qualquer leitura:

Esta resistência do texto a certas variações ideológicas contextuais e não a outras explica-se apenas se é aceito que o texto mesmo possui marcas próprias de isotopias de leitura (e no caso que nos preocupa, suas marcas de veridicção), que limitam as possibilidades de variação (GREIMAS, 1983, p. 106; tradução nossa) ${ }^{4}$.

Para Greimas, uma tipologia estrutural das atitudes epistêmicas, ou ainda, das interpretações conotativas dos discursos deveria ser possível. Ele chega mesmo a sugerir alguns exemplos, como a exploração da materialidade do significante para assinalar a verdade do significado.

$\mathrm{Na}$ continuidade da proposição de Greimas, Fiorin, em "A crise da representação e o contrato de veridicção no romance" (2008), procura depreender, a partir, principalmente, da análise da produção brasileira, grandes procedimentos de representação da realidade no romance, compreendendo a

\footnotetext{
4 "Cette résistance du texte à certaines variations idéologiques contextuelles et non à d'autres ne s'explique que si l'on accepte que le texte lui-même possède ses propes marques d'isotopies de lecture (et dans le cas qui nous préoccupe, ses marques de véridiction) que en limitent les possibilités".
} 
noção de representação a partir da poiese, ou seja, ela é também construção, efeito de sentido. Distingue os seguintes contratos: objetivante, subjetivante, semiótico, metalinguístico.

No mesmo quadro teórico, Bertrand (2003a) também se dedica à noção de contrato veridictório, mas a partir de uma reflexão sobre a figuratividade. $O$ autor propõe quatro grandes vias de leitura do texto literário, cujo centro é a modalidade do crer: o crer assumido, o crer recusado, o crer crítico e o crer em crise.

Após criticar a concepção do "estruturalismo estático", que estabelece uma "correspondência" unívoca e mecânica entre as vias figurativas da linguagem e o mundo, Bertrand retoma e desenvolve ideias apresentadas por Greimas em Da imperfeição (2002). A figuratividade e o mundo seriam antes duas instabilidades que procuram, em vão, uma compatibilidade. A correspondência fica a cargo das convenções: "[...] a correspondência se faz pelo crivo cultural que the é aplicado, tornando possível, por meio de convenções coercitivas mas provisórias, consistentes mas precárias, a legibilidade figurativa" (p. 405). Para o semioticista é então a dimensão figurativa que rege os diferentes modos de participação e adesão na leitura:

Sob o figurativo está, portanto, o crer; existe, como se diz na semiótica, um "contrato de veridiç̧ão", uma relação fiduciária de confiança e de crença entre os parceiros da comunicação, que especifica as condições da correspondência, um crer partilhável e partilhado no interior das comunidades linguísticas e culturais, que determina a habilitação dos valores figurativos e enuncia seu modo de circulação e validade. É esse contrato que tematiza a figuratividade do discurso e engendra diferentes regimes de persuasão e de adesão: o verossímil e a ficção, o real e o fantástico, o representável e o absurdo (p. 405-406).

Nossa intenção não é a de retomar as propostas de Fiorin para o romance brasileiro ou de Bertrand para a literatura em geral, mas mostrar a produtividade da noção de contrato veridictório, ou contrato enunciativo, e, a partir de tal noção, examinar as relações entre enunciador e enunciatário no discurso da memória. Os elementos que participam da construção do sentido de cada texto ou em cada gênero serão examinados tendo em vista seu papel nessa interação. 
Discini, para romper com a dicotomia real/fictício, apoia-se também na veridicção. Para isso, recorre à noção de escopo, entendida como uma espécie de fiador da verdade, com função diferente no discurso da arte e no discurso da vida: "Entre as extremidades e com oscilação possível mais para uma e menos para outra, estão ancorados os gêneros discursivos. Aqueles de fronteira circulam em mais de uma esfera de comunicação" (2009, p. 610). No discurso da arte, a construção do referente se distanciaria do "contexto pragmático imediato"; o contrário ocorreria no discurso da vida. A autora ilustra suas afirmações com uma breve comparação entre a literatura e o jornal:

Para distinguir literatura de jornal temos em mente que há diferentes modos de fazer assentar o relato na veridicção. O mesmo se dá em relação aos gêneros. Naqueles relativos ao discurso jornalístico, como a reportagem, a veridicção não acolherá como próxima sua variável tipológica, a verossimilhança, mais móvel em relação ao escopo do "contexto pragmático". A literatura goza de um grau maior de autocentramento da palavra (p. 607).

As interações que se estabelecem entre o enunciador e o enunciatário variam conforme os diferentes gêneros discursivos. Se retomamos a primeira definição de "contrato" dada pelo Dicionário de semiótica, temos: uma estrutura intersubjetiva que se constitui como "[...] por um lado, uma abertura sobre o futuro e sobre as possibilidades da ação e, por outro, uma coerção que limita de certa forma a liberdade de cada um dos sujeitos" (GREIMAS; COURTÉS, 2008, p. 100). Podemos pensar o gênero, então, como algo que organiza o contrato firmado entre os parceiros da comunicação.

Para definir gênero, teremos como ponto de partida o conceito estabelecido por Bakhtin e herdado pela teoria semiótica: "No âmbito dos estudos do discurso, o gênero pode ser entendido como um acontecimento que orienta a presença sensível" (DISCINI, 2010, p. 11). Segundo Bakhtin, gêneros são tipos de enunciados relativamente estáveis:

O emprego da língua efetua-se em forma de enunciados (orais e escritos) concretos e únicos, proferidos pelos integrantes desse ou daquele campo da atividade humana. Esses enunciados refletem as

\footnotetext{
${ }^{5}$ As noções de discurso da arte e discurso da vida têm base na obra de Volochinov (1976).
} 
condições específicas e as finalidades de cada referido campo não só por seu conteúdo (temático) e pelo estilo da linguagem, ou seja, pela seleção dos recursos lexicais, fraseológicos e gramaticais da língua mas, acima de tudo, por sua construção composicional. Todos esses três elementos - o conteúdo temático, o estilo, a construção composicional - estão indissoluvelmente ligados no todo do enunciado e são igualmente determinados pela especificidade de um determinado campo da comunicação. Evidentemente, cada enunciado particular é individual, mas cada campo de utilização da língua elabora seus tipos relativamente estáveis de enunciados, os quais denominamos gêneros do discurso (2006, p. 261-262).

Para o pensador russo, os enunciados devem ser estudados em sua relação com o processo de interação, uma vez que a linguagem a as atividades humanas não podem ser dissociadas; daí a pertinência do exame da noção de esfera de circulação, ou seja, o domínio de atividades no qual circulam os gêneros. Esses domínios refletem nos gêneros suas condições específicas e suas finalidades, e, assim, interferem no modo como é estabelecida a interação entre enunciador e enunciatário. É possível pensar nisso ainda de outra forma: o exame dessa interação ajuda a descrever as relações entre esferas e gêneros, por meio da leitura das marcas recuperáveis nos discursos enunciados.

O gênero caracteriza-se, como aponta Bakhtin, por uma temática, um estilo e uma forma composicional. A temática "[...] não é o assunto de que trata o texto, mas é a esfera de sentido de que trata o gênero" (FIORIN, 2005a, p. 102). É por meio do estudo da semântica discursiva que podemos depreender a temática dos gêneros estudados. A forma composicional diz respeito à organização do texto e da linguagem, ou seja, ajuda a compreendê-la o exame da discursivização dos tempos, espaços e pessoas, e o da textualização, daí os tipos textuais ganharem relevância. Eles são, segundo Fiorin (2005a, p. 102103), construções textuais que apresentam determinadas características linguísticas, devendo ser observados a partir de relações de dominância e não de exclusividade (FIORIN, 2005a, p. 104). Os seis tipos mais comuns são: o narrativo, o descritivo, o injuntivo, o expositivo, o opinativo e o argumentativo. Esses três últimos reúnem-se geralmente num macrotipo, a dissertação.

O estilo do gênero, ou seja, sua entonação própria resulta do conjunto de marcas linguísticas e discursivas. É possível pensar em estilo do gênero e 
em estilo autoral, menos submetido às coercões genéricas. A literatura é mais propícia ao fortalecimento do estilo autoral, enquanto documentos oficiais, pertencentes a gêneros mais estereotipados, menos. Frisamos, no entanto, que mesmo o estilo autoral está, em parte, sujeito às coerções de gênero e que nem todos os gêneros são igualmente aptos para refletir a individualidade do estilo autoral.

O estudo do estilo leva-nos ao éthos, entendido como a imagem do enunciador, ou ainda, como corpo, voz e caráter, reconstituídos a partir de uma totalidade discursiva. Como afirma Maingueneau sobre o éthos: "Não se trata de uma representação estática e bem delimitada, mas, antes, de uma forma dinâmica, construída pelo destinatário através da própria fala do locutor" (2008, p. 14). Assim, o éthos será entendido, tal como vem sendo trabalhado pela semiótica de linha francesa, como um modo de ser e habitar o mundo depreendido enquanto imagem do enunciador e produzido pelas recorrências de um modo próprio de dizer, ou seja, por um fazer. Ele é determinado na relação de comunicação e, assim, só pode ser buscado pelo analista no próprio discurso. Nesse sentido, o estilo é o próprio éthos:

Pensamos no estilo como o modo próprio de dizer de uma enunciação, única, depreensível de uma totalidade enunciada. Essa perspectiva faz com que as relações de sentido convirjam recorrentemente para um centro que, longe de mostrar um sujeito empírico, cria o próprio sujeito (DISCINI, 2003, p. 17).

A depreensão do éthos constitui parte importante do exame da relação entre os parceiros da comunicação, o enunciador e o enunciatário, pois, ao projetar um simulacro, o enunciador leva em conta a imagem que acredita que o enunciatário possui dele (DISCINI, 2003, p. 29). Os gêneros mais flexíveis, como os literários, permitem recortar, com grande facilidade, diferentes éthe nas obras que os realizam, o que não ocorre com aqueles pouco flexíveis, como receitas e bulas de remédio, pois apresentam um éthos mais estereotipado. Um discurso de um determinado gênero que manifeste um éthos do enunciador não esperado pelo enunciatário pode comprometer a relação de crença existente entre eles ou, então, renová-la. Afinal, o gênero também funciona como um fator coercitivo. 
A bula, conforme mostra Discini (2009), é um gênero bastante rígido e que, assim, não permite muita variabilidade na construção do simulacro do enunciador; pressupõe um estilo tendente aos efeitos de objetividade, com "ares" de discurso científico e um corpo construído como asséptico e isento. Imaginemos agora uma bula de remédio que, ao contrário do previsto, possua um éthos passional, descomedido, ao qual falta a objetividade. A presença desse éthos, como fiador do discurso que é, em princípio, tornaria não confiável tudo o que é dito ali. Além disso, ela poderia criar uma sensação de desconforto, de estranhamento para o enunciatário, que pode ser indesejável, a não ser no caso de tratar-se de uma paródia do gênero. Não se deve esquecer que as coerções de gênero podem prestar-se a subversões.

Confirma-se, portanto, a pertinência do estudo do éthos para a compreensão das relações estabelecidas entre enunciador e enunciatário. Todorov afirma, em Os gêneros do discurso (1981, p. 52), que o gênero é um "modelo de escrita" para o enunciador e um "horizonte de espera" para o enunciatário.

Para cumprir o objetivo de examinar as relações entre contratos enunciativos e gêneros autobiográficos, selecionamos, para formar o corpus desta pesquisa, textos pertencentes a diversos gêneros que materializam o discurso da memória. $O$ corpus de análise aqui reunido remete ao discurso acadêmico, no gênero memorial, bem como ao discurso literário em prosa e em verso. Para os primeiros, temos como totalidade de partida 20 exemplares reunidos em duas áreas do conhecimento: Letras e Biociências. Além disso, a demanda se circunscreve aos textos produzidos na situação de um concurso: de efetivação docente, de livre-docência, de titularidade. A instituição que acolhe tais concursos é a Universidade de São Paulo, no período que vai de 1970 até a contemporaneidade. Memoriais de outras instituições são trazidos para comparação.

A segunda frente oferecida pelo corpus de análise, posta no discurso literário, prioriza, para a autobiografia literária em prosa (o romance), dois núcleos fundamentais representados pela obra de Pedro Nava e de Graciliano Ramos, autores paradigmáticos da "escritura da memória" no Brasil e que já foram trabalhados por nós em outras pesquisas. Para aquele, temos à mão os livros Baú de ossos (2000) e Galo das trevas (2003); para este, Infância (2003). 
Quanto à poesia, trazemos quatro poemas de caráter autobiográfico de Manuel Bandeira (1993): "Evocação do Recife" e "Profundamente", de Libertinagem; "Infância", de Belo Belo; "Recife", de Estrela da tarde. Tais poemas foram incorporados à pesquisa, principalmente, por permitirem uma comparação entre o modo de fazer autobiografia em poesia e em prosa. Além disso, somados à prosa literária, possibilitam uma análise mais abrangente do discurso autobiográfico literário e ainda a contraposição desta nova totalidade aos memoriais acadêmicos. Viabiliza-se, assim, o estudo das relações entre contratos enunciativos e gêneros autobiográficos, bem como o das relações entre gêneros e esferas de circulação, no caso, a literária e a acadêmica.

A extensão do corpus explica-se na medida em que se verifica a flexibilidade dos gêneros autobiográficos, especialmente, no século $X X$, conforme frisam Galle e Olmos:

A autobiografia, em evidente sintonia com o romance do período, respondeu a esse desafio com experimentos formais que transgrediam os códigos precedentes e dinamizavam os princípios de produção discursiva das formas autobiográficas, estabelecendo um jogo de submissão e transgressão às leis do gênero que, longe de provocar uma recessão desse modelo de discurso, estimulou a produtividade dos autores até os dias de hoje (2009, p. 10).

Em síntese, os objetivos desta tese são: examinar as diferentes organizações do discurso autobiográfico, das quais emergem diferentes modos de interação entre o enunciador e o enunciatário; investigar as relações entre a variação dessas formas de interação e os gêneros autobiográficos e, por fim, discutir as relações entre esses gêneros e as esferas de atividade pelas quais circulam.

Os fundamentos teóricos e a metodologia para a realização dos objetivos propostos, conforme já mencionamos, são os da semiótica de orientação greimasiana. Dentre as possibilidades oferecidas pela teoria, destacaremos os estudos semióticos da enunciação e os estudos semióticos da tensividade, especialmente as noções de acontecimento e exercício (ZILBERBERG, 2007b) e de campo de presença (FONTANILLE; ZILBERBERG, 2001). A noção de campo de presença, tal como desenvolvida por um ponto de vista tensivo, será um dos nortes epistemológicos que 
respaldarão o exame das formas de adesão do enunciatário aos discursos autobiográficos, uma vez que, em cada gênero e mesmo em cada texto, o enunciador, ao apresentar retrospectivamente a sua vida, regulamenta de forma singular a entrada das grandezas no campo de presença do enunciatário. Pretendemos, assim, investigar de que forma o enunciatário é afetado sensivelmente nos diferentes gêneros autobiográficos e ainda como esse fazer sensibilizador do enunciador interfere na relação fiduciária estabelecida entre os parceiros da comunicação. Conforme afirma Discini:

Acolhemos o ponto de vista tensivo da semiótica, já que buscamos meios de obtenção da presença sensível, para, quem sabe, viabilizar uma maior integração da noção de estilo, autoral e dos gêneros, aos próprios estudos semióticos (2010, p. 3).

Nossa pesquisa conta ainda com as contribuições da teoria literária e de autores de outras linhas de análise do discurso, retomadas na perspectiva semiótica, além de dialogar com a filosofia da linguagem de M. Bakhtin, para a abordagem da noção de gênero, e com as reflexões a respeito da memória oriundas de outras áreas, como a filosofia, a sociologia e a psicologia. As questões teóricas e metodológicas serão apresentadas e discutidas ao longo do trabalho.

A tese está organizada em quatro capítulos. O primeiro, dedicado ao estudo da prosa literária, comporta Baú de ossos e Galo-das-trevas, de Pedro Nava, e Infância, de Graciliano Ramos. Recuperando pesquisas anteriores desenvolvidas por nós, especialmente no mestrado, este capítulo traz uma breve discussão a respeito do romance autobiográfico, em que procuramos apresentar algumas de suas características. Em seguida, descrevemos os procedimentos empregados em cada um dos livros de Nava para a criação do triplo efeito de identidade entre enunciador, narrador e protagonista, que caracteriza o discurso autobiográfico. Nesse sentido, Galo-das-trevas é obra bastante peculiar, uma vez que, no final do primeiro capítulo, o narrador decide deixar de relatar sua própria história e passar a de seu alter ego, Egon. Examinamos também a construção do passado nas duas obras de Pedro Nava e as paixões que dominam o enunciador. O livro Infância é trazido ao capítulo principalmente a título de comparação, o que nos dá alguma tranquilidade para 
falar de características gerais da prosa autobiográfica literária, já que a obra de Nava e a de Graciliano são bastante diferentes.

O segundo capítulo, ainda dentro da esfera literária, dedica-se ao estudo dos quatro poemas selecionados de Bandeira: "Evocação do Recife"; "Profundamente"; "Infância"; "Recife". Enfatizamos nessa parte a noção de existência semiótica, pois o jogo de velar e desvelar o passado lembrado mostra-se determinante para a construção de sentido dos poemas. É preciso dizer que, ao fazer-se linguagem, a memória se configura como presença, e também como ausência, já que a escritura é a experiência presente de um tempo que não existe mais. Logo, presença e ausência parecem constituir os termos de uma categoria fundamental para o exame das relações entre memória e linguagem. Analisamos cada poema separadamente, para ao final apresentarmos alguns elementos comuns aos quatro textos e que parecem definir um modo singular de fazer autobiografia e de estabelecer a interação entre o enunciador e o enunciatário.

O memorial acadêmico constitui o foco do terceiro capítulo. Inicialmente, fazemos um estudo do simulacro do vivido elaborado no gênero e de seus efeitos sobre o enunciatário, buscando observar se é construído como "linha reta", sem bifurcações, ou como sucessão de surpresas e desvios. Em seguida, a partir da comparação entre os textos, depreendemos dois modelos diferentes de memorial, enfatizando especialmente as diferenças de estilo e de constituição do éthos, e, consequentemente, as mudanças no contrato enunciativo.

O quarto capítulo antecipa, de certo modo, algumas conclusões da tese. Retomando aquilo que foi apresentado nos capítulos anteriores, confrontamos os diferentes gêneros estudados, o que possibilita a organização desses gêneros num gradiente tensivo. Inclinado à generalização e à formalização teórica, o capítulo propõe categorias de análise da organização geral do discurso autobiográfico que propiciam, entre outras coisas, o exame das relações entre enunciador e enunciatário.

$\mathrm{Na}$ conclusão, são afinadas as sistematizações esboçadas; mais do que isso, a conclusão retoma considerações feitas sobre a natureza dos gêneros na vinculação destes com diferentes esferas da comunicação humana para que se interpele o estar-no-mundo do sujeito que se lança em autobiografias. 
CAPÍTULO 1

\section{A AUTOBIOGRAFIA LITERÁRIA EM PROSA:}

\section{A CRIAÇÃO DO PASSADO}

Querer dizer o indizível, pintar o invisível: provas de que a coisa, única, adveio, que outra coisa seja talvez possível. Nostalgias e esperas alimentam o imaginário cujas formas, murchas ou desabrochadas, substituem a vida: a imperfeição, desviante, cumpre assim, em parte, seu papel.

Algirdas Julien Greimas

Da imperfeição

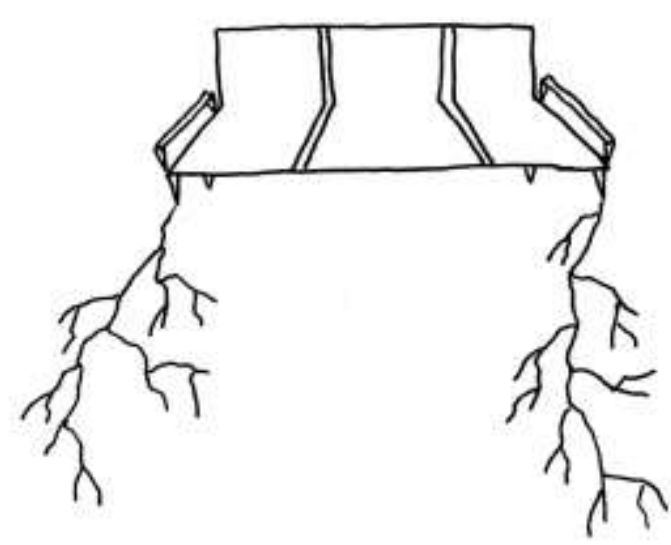




\section{GÊNERO}

Os diários, as cartas, os memoriais acadêmicos, os romances autobiográficos são gêneros que realizam o discurso autobiográfico, cuja marca central é, além da temática da "minha vida" - o "eu" é o centro do discurso -, a produção do efeito de identidade entre o enunciador (autor implícito) e o narrador; o narrador e o protagonista (ator central do narrado); o protagonista e o enunciador. O papel dessa tripla relação de identidade nos gêneros autobiográficos vem sendo debatido por diversos pesquisadores.

Lejeune apresenta a seguinte definição para a autobiografia: "Relato retrospectivo que uma pessoa real faz de sua própria existência, quando ela coloca ênfase sobre sua vida individual, em particular sobre a história de sua personalidade" (1996, p. 14; tradução nossa) ${ }^{6}$. O teórico a analisa a partir da noção de pacto autobiográfico, ou seja, uma espécie de contrato estabelecido entre o autor e o leitor, ou ainda um ato de linguagem, um performativo, uma promessa. Em oposição ao pacto romanesco, trata-se de um compromisso assumido pelo autor de contar sua vida num espírito de verdade, o que acarreta uma forma de leitura específica. Para Lejeune (1996; 2005), o pacto autobiográfico não diz respeito à correspondência ponto por ponto do texto à vida extralinguística. O autor afirma, porém, que seria legítimo verificar a existência de uma adequação em nível mais amplo, pois, para ele, aquele que escreve uma obra autobiográfica compromete-se definitivamente com a verdade. O teórico relativiza em parte essa visão quando lida com obras autobiográficas mais literárias. A concepção primordial de Lejeune é, todavia, a de que a autobiografia institui um pacto referencial de leitura, como o discurso histórico ou científico, posição que não será assumida neste trabalho, conforme mostraremos ao longo dos capítulos.

Ainda segundo Lejeune (1996; 2005), o pacto autobiográfico é fundamentado, essencialmente, na relação de identidade entre autor e narrador, narrador e personagem central, personagem central e autor. Trata-se do que Genette (1991, p. 83) entende por discurso homodiegético não ficcional:

\footnotetext{
6 "Récit rétrospectif en prose qu'une personne réelle fait de sa propre existence, lorsqu'elle met l'accent sur sa vie individuelle, en particulier sur l'histoire de sa personnalité".
} 


$$
A=\text { autor }, P=\text { personagem }, N=\text { narrador }
$$

$A=P, P=N, N=A \rightarrow$ autobiografia (discurso homodiegético não ficcional)

$A \neq P, P \neq N, N=A \rightarrow$ biografia (discurso heterodiegético não ficcional)

$A \neq P, P=N, N \neq A \rightarrow$ ficção homodiegética

$A=P, P \neq N, N \neq A \rightarrow$ autobiografia heterodiegética

$A \neq P, P \neq N, N \neq A \rightarrow$ ficção heterodiegética

Desses autores, herdamos essa noção de tripla identidade, mas como efeito que cria a ilusão de que a vida narrada pertence ao enunciador. No entanto, como afirma Parret: “'Minha vida' é uma narrativa, um discurso: que esta vida seja minha não é senão um efeito de discurso, um simulacro discursivo" (1988, p. 43; tradução nossa) ${ }^{7}$. O efeito de identidade entre narrador e protagonista é produzido, geralmente, pelo emprego do pronome eu, ou seja, por uma debreagem enunciativa do enunciado: "quando o narrador se identifica com uma das personagens, naquilo que concerne ao enunciado enunciado, ou seja, ao eu actante da narrativa" (FIORIN, 1996, p. 117). Já o efeito de identidade entre enunciador e protagonista pode realizar-se pela onomástica, que concretiza semanticamente num mesmo antropônimo o ator da enunciação e o ator do narrado. Lejeune (1996) chama a atenção para a coincidência do nome do autor, na capa do livro, e o da personagem.

O efeito de identidade entre narrador e enunciador resulta das identidades anteriores, podendo ser fortalecido pelo fato de o narrador apresentar-se, muitas vezes, como o autor da obra. É o que chamamos na semiótica de embreagem:

Ao contrário de debreagem, que é a expulsão, da instância da enunciação, de termos categóricos que servem de suporte ao enunciado, denomina-se embreagem o efeito de retorno à enunciação, produzido pela suspensão da oposição entre certos termos da categoria da pessoa e/ou do espaço e/ou do tempo, bem como pela denegação da instância da enunciação. Toda embreagem pressupõe, portanto, uma operação de debreagem que the é logicamente anterior (GREIMAS; COURTÈS, 2008, p. 159-160).

\footnotetext{
7 “'Ma vie' est un récit, un discours: que cette vie soit à moi n'est qu'un effet de discours, un simulacre discursif".
} 
Nesse caso, temos um tipo de embreagem que confunde os níveis do narrador e do enunciador, instância pressuposta, criando a aproximação entre eles (FIORIN, 1996, p. 122-123). O narrador, instalado no enunciado sempre como um não-eu em relação à enunciação, é apresentado como se fosse o enunciador $^{8}$. Isso aparece com frequência na abertura das obras, especialmente depois de Rousseau, que inicia suas Confissões (1933) com um pequeno texto assinado, no qual justifica, então, não apenas o que levou o narrador a contar sua história, mas os motivos que fizeram com que o enunciador a escrevesse e publicasse.

É o que encontramos também na obra de José de Alencar, Como e por que sou romancista, que data de 1873 e foi publicada postumamente em $1893^{9}$.

Meu amigo

$\mathrm{Na}$ conversa que tivemos, há dias, exprimiu V. o desejo de colher acerca da minha peregrinação literária alguns pormenores dessa parte íntima de nossa existência, que geralmente fica à sombra, no regaço da família ou na reserva da amizade.[...] Seria esse o livro dos meus livros. [...] Enquanto não vem ao lume do papel, que para o da imprensa ainda é cedo, essa obra futura, quero em sua intenção fazer o rascunho de um capítulo.

Será daquele, onde se referem as circunstâncias, a que atribuo a predileção de meu espírito pela forma literária do romance (1955, p. 57).

Outras estratégias discursivas podem contribuir para reforçar as identidades próprias ao gênero, como a explicitação no título ou subtítulo do fato de tratar-se de uma obra autobiográfica (memórias, história da minha vida, lembranças, etc.) (LEJEUNE, 1996). Isso cria no enunciatário a expectativa,

${ }^{8}$ É preciso lembrar que a debreagem, concernente à instauração de pessoas, tempos e espaços no enunciado, consiste num primeiro momento "[...] em disjungir do sujeito, do espaço e do tempo da enunciação e em projetar no enunciado um não-eu, um não-aqui e um nãoagora" (FIORIN, 1996, p. 43).

${ }^{9}$ Esse livro pode ser considerado um dos precursores da literatura memorialista no Brasil, pois, conforme mostra Fávero (1999, p. 31), traz inúmeros temas retomados mais tarde pelas obras autobiográficas produzidas em nosso país. Também Castelo (1999, p. 385) aponta José de Alencar como um dos autores que marcam o surgimento da literatura memorialista no Brasil, sendo os outros Joaquim Nabuco e Graça Aranha, que escreveram no final do século XIX. Seria preciso ainda pensar no papel dos cronistas dentro de uma história dos gêneros autobiográficos no Brasil. 
que pode ser confirmada ou não, de convergência das três instâncias mencionadas.

A identidade entre protagonista, narrador e enunciador é, então, característica dos discursos da memória e, assim, do romance autobiográfico. Outros elementos ajudam ainda a definir o gênero quanto à sua estrutura composicional. Destacaremos os principais. A história é narrada, predominantemente, de forma retrospectiva e cronológica, mesmo que antecipações e recuos se façam sempre presentes. O tempo dominante é, normalmente, o passado, recriado pelo sistema enuncivo pretérito, que instala um então no discurso, em oposição ao agora da enunciação (FIORIN, 1996, p. 154). É, porém, a partir do presente que o narrador relata e recorda o passado. Logo, as debreagens temporais enuncivas mesclam-se às enunciativas. Daí a afirmação de Molloy (1996, p. 11), de que os textos autobiográficos tentam realizar o impossível: narrar a história passada de uma primeira pessoa que, por definição, só existe no presente de sua enunciação.

A temática do romance autobiográfico é a vida pessoal e pública, assumida como "minha vida" pelo narrador e pelo enunciador. A "minha vida" surge como simulacro depreendido na recriação do passado por meio da narrativa das memórias, da qual decorre a construção do sujeito ou ainda de sua identidade. Quanto ao estilo, observa-se a enorme flexibilidade do gênero, afinal pertence à esfera literária. Isso possibilita o uso de diferentes normas linguísticas e favorece o fortalecimento dos estilos autorais.

Apresentamos a seguir o quadro que sugere a forma composicional, o estilo e a temática da autobiografia literária em prosa ${ }^{10}$. Nosso objetivo não é o de um fazer prescritivo, já que o quadro teve origem na observação e análise de recorrências. Nada impede que ele venha a se modificar.

\section{Estrutura composicional:}

- efeito de identidade entre enunciador, narrador e ator, criado por diferentes recursos;

- presença do sistema temporal enunciativo e do sistema temporal enuncivo pretérito;

\footnotetext{
${ }^{10}$ Esse quadro retoma pesquisas anteriores (BARROS, 2006).
} 
- predomínio do sistema enuncivo pretérito (essa dominância é maior em certas obras do que em outras);

- predomínio do sistema enuncivo espacial, embora o enunciativo também possa ser utilizado;

- narração da história em ordem cronológica, o que significa que a história vai do período mais distante ao mais recente (podem ser encontrados avanços e recuos no texto, tratados como embreagens de tempo, entretanto, a ordem cronológica, normalmente, predomina);

- predomínio do tipo textual narrativo ${ }^{11}$;

- texto figurativo (alto grau de densidade semântica na construção de pessoas, tempos e espaços);

- destaque para os papéis temáticos pessoais do narrador (enunciador).

Estilo:

- grande flexibilização do gênero no encontro com o estilo autoral, fortalecimento dos estilos autorais;

○ utilização de diferentes normas e registros linguísticos;

- configuração do éthos dependente, entre outros aspectos, da relação que o enunciador estabelece com seu passado;

- efeito de aproximação entre enunciador e enunciatário, criado pelo uso do sistema enunciativo de pessoa;

- efeito de aproximação entre sujeito da enunciação e enunciado, criado pelo uso do sistema enunciativo de pessoa;

- efeito de distanciamento e objetividade entre sujeito da enunciação e enunciado, criado pelo uso do sistema enuncivo de tempo e de espaço.

\section{Temática:}

- memória da vida pessoal e pública.

\footnotetext{
${ }^{11}$ Em obras mais recentes, a descrição, assim como tipos dissertativos vêm sendo largamente empregados.
} 


\section{ESTUDO DE CASO}

"Eu sou um pobre homem do Caminho Novo das Minas dos Matos Gerais" (2000, p. 5), assim começam as extensas Memórias de Pedro Nava, talvez a obra autobiográfica mais festejada da literatura brasileira. Aguiar ressalta o impacto que teve sua publicação:

Ao lançar suas Memórias, Nava logo se tornou um best-seller. A cada volume publicado, seu nome ia para a lista de mais vendidos. Certamente, seu modo de reconstruir o tempo, num estilo exuberante, refinado, divertido e por demais envolvente, foi decisivo para o sucesso da obra junto ao público e também à crítica (1998, p. 13-14).

Para o crítico, Nava vem preencher um lugar deixado vago na tradição do memorialismo brasileiro: "É como se o próprio gênero tivesse se reservado para ele, à espera do seu melhor praticante" (AGUIAR, 1998, p. 16). O autor, que já beirava os setenta anos e que pouco havia publicado na esfera literária - alguns poemas e crônicas -, lança ao longo de pouco mais de uma década seis volumes de memórias, Baú de ossos (2000), Balão cativo (2000), Chão de ferro (2001), Beira-mar (2003), Galo-das-trevas (2003) e O círio perfeito (2004), consagrando-se como escritor. O sétimo livro, Cera das almas (2006), publicado postumamente, teve sua redação interrompida pelo suicídio do autor em maio de $1984^{12}$.

Nossa análise terá como centro o primeiro - Baú de ossos (BO) - e o quinto volume - Galo-das-trevas (GT) - das Memórias, por acreditarmos que eles sintetizam algumas características importantes da obra de Nava e que possuem, ao mesmo tempo, peculiaridades que os tornam centrais para a compreensão de sua memorialística, conforme mostraremos. Primeiro abordaremos a questão das identidades e, em seguida, a organização discursiva da memória.

Baú de ossos está dividido em quatro partes: "Setentrião", "Caminho Novo", "Paraibuna" e "Rio Comprido". Em "Setentrião", o narrador, após

12 Informamos a data das primeiras edições: Baú de ossos (1972), Balão cativo (1973), Chão de ferro (1976), Beira-mar (1978), Galo-das-trevas (1981), O círio perfeito (1983), Cera das almas (2006). 
traçar algumas observações de cunho sociológico e geográfico a respeito de Juiz de Fora, cidade em que nasceu, passa a falar da família de seu pai. Começa por seus antepassados mais distantes até chegar aos avós. Já a segunda parte é dedicada à família de sua mãe. Inicia-se com uma breve análise bastante impiedosa da sociedade mineira, que já anuncia a maneira como os antepassados do lado de sua mãe - mineiros conservadores, escravocratas, monarquistas, antigos proprietários de terras e mineradores serão vistos, em oposição aos parentes de seu pai, no geral funcionários públicos vindos do Ceará e do Maranhão, gente mais liberal e benevolente.

"Paraibuna" descreve a vida do pai, José Pedro da Silva Nava, e de seus amigos e colegas de trabalho. Relata também a primeira infância de Pedro Nava em Juiz de Fora. "Rio Comprido", a última parte, conta a experiência da família no Rio, os passeios do menino com o tio Salles, o movimento dos vendedores na rua, as viagens para a casa da avó em Juiz de Fora, onde a mulata Rosa lhe contava histórias. É principalmente nessa parte que o narrador interrompe a história para discorrer a respeito da memória. O livro termina com a partida da mãe, Diva Mariana Jaguaribe, e das crianças para Juiz de Fora, como consequência da morte traumática do pai:

Não sei se sofri na hora. Mas sei que venho sofrendo destas horas, a vida inteira. Ali eu estava sendo mutilado e reduzido a um pedaço de mim mesmo, sem perceber, como o paciente anestesiado que não sente quando amputam sua mão. Depois a ferida cicatriza, mas a mão perdida é dor permanente e renovada, cada vez que a intenção de um gesto não se pode completar (BO, p. 376).

Balão cativo (BC), o segundo volume das Memórias, trata da vida do menino em Juiz de Fora, na casa da avó, Inhá Luísa, lugar para onde a mãe retorna com os filhos. Esse período sob os desmandos da avó é retomado com pesar:

Não importa muito a direção. O que sei é que aquela encosta do morro e a sombra que dele se derramava sobre a chácara da Inhá Luísa ficaram representando o lado noruega da minha infância. Nunca batido de sol (BC, p. 5). 
Após a morte de Inha Luísa, o avô, Joaquim José Nogueira Jaguaribe, resolve mudar-se com toda a família para Belo Horizonte. Alguns anos depois, já adolescente, o jovem Nava retorna ao Rio para estudar no Internato do Colégio Pedro II, ficando sob os cuidados dos tios Alice e Antonio Salles.

Chão de ferro (CF) dá continuidade à narrativa dos anos passados no internato, sem deixar de lado outros temas importantes na vida do adolescente. Os estudos na Faculdade de Medicina em Belo Horizonte são um dos focos de Beira-mar (BM), que intercala relatos de aulas aos das noites de boemia. $O$ livro trata ainda de sua participação na vida literária da cidade. Membro do grupo modernista mineiro, Nava teve, entre seus amigos, Carlos Drummond de Andrade, Aníbal Machado, João Alphonsus, Milton Campos e outros.

Galo-das-trevas encontra-se dividido em duas partes. A primeira, "Negro", cujo capítulo único se intitula "Jardim da Glória à Beira-Mar plantado", constitui um momento de exceção na obra de Nava. Vamos reencontrar o tempo e o espaço da narração, pois o narrador, um homem velho e amargurado, fala de seu presente a partir do apartamento no bairro da Glória (Rio de Janeiro). Relata os encontros com seus mortos numa noite de insônia, seus passeios pelo Rio, lugar impregnado de lembranças, mas que já não é mais o mesmo. No final dessa parte, ele anuncia que passará a narrar as memórias daquele que diz ser seu alter ego, José Egon Barros da Cunha. $\mathrm{Na}$ segunda parte, "O branco e o marrom", formada pelos capítulos "Santo Antônio do Desterro" e "Belorizonte Belo", Egon se torna então personagem central. Ele já havia aparecido nos volumes anteriores das Memórias, sendo apresentado como um primo de Pedro Nava, um sósia, e mesmo um alter ego. O primeiro capítulo dessa segunda parte narra a expedição para Caetés, a verdadeira estreia como médico do Dr. Egon, seu "batismo", como diz o narrador. Em seguida, o médico parte para Santo Antônio do Desterro, sua cidade natal, que corresponderia a Juiz de Fora, de onde é Pedro Nava. A cidade não o acolhe como esperava e o jovem decide retornar a Belo Horizonte um ano e meio depois de sua chegada. O segundo capítulo é dedicado ao período em Belo Horizonte, onde Egon encontra certa estabilidade. O livro termina com os tiros anunciando a Revolução de 30.

$O$ círio perfeito $(\mathrm{CP})$ continua a narrativa do período que Egon passa em Belo Horizonte, bruscamente interrompido pelo suicídio de sua noiva. O jovem 
médico decide então afastar-se e ir para o Oeste Paulista, onde consegue acumular um pequeno capital que lhe permite instalar-se mais uma vez no Rio de Janeiro.

A obra de Nava parece definir-se pelo excesso. Nela, é narrada não apenas a história pessoal do "autor", mas a de seus antepassados e também de amigos e conhecidos da família, a história de uma época, vista por um prisma pessoal. Além disso, seu estilo, dado ao ornamento, mescla registros e dialetos. Como mostra Arrigucci, não faltam:

[...] termos regionais e coloquialismos; palavras esquecidas, com o dom de ressuscitar o passado de que um dia foram parte; vocábulos cultos e preciosos, nomes exóticos que deixam sabor na boca; palavrões em quantidade; estrangeirismos, sobretudo galicismos abundantíssimos; tecnicismos da linguagem médica e científica em geral; neologismos; tesouros dos clássicos portugueses; uma verdadeira avalanche de nomes próprios, muitas vezes já esvaziados das pessoas e lugares que os habitaram, com a rara e surpreendente poesia de seu puro som; latinismos e todo o baú de virtualidades da língua, atualizadas, arejadas, encarnadas concretamente e postas a caminhar na frase aberta e inclusiva sob a luz do presente (1987, p. 72-73).

Outra obra autobiográfica da literatura brasileira será trazida para comparação com as Memórias de Nava: Infância (2003), de Graciliano Ramos. Lançado em 1945, trata-se de um livro autobiográfico que se constitui de forma radicalmente diferente do que encontramos nas Memórias, o que permitirá uma discussão mais ampla ao final a respeito do gênero autobiográfico na literatura.

Em Infância, um narrador, nada saudoso, conta seus primeiros anos de vida no interior do Nordeste (Pernambuco/Alagoas). Ele relembra a infância como um período de sofrimento e incompreensão, revendo, assim, o lugarcomum da infância idílica: "[...] os castigos imerecidos, as maldades sem motivo, de que são vítimas os fracos, estão na base da organização do mundo" (CANDIDO, 1992, p. 53). É na leitura que o menino encontra a possibilidade de evasão, assim como é pela escrita literária que o narrador busca ressignificar suas memórias.

Os 39 capítulos que compõem o livro são bastante curtos - possuem em torno de 5 páginas - e mantêm certa autonomia em relação ao todo. Cada um deles centra-se numa grande transformação ocorrida com a criança. Muitos 
desses capítulos já haviam sido publicados separadamente em jornais e revistas da época, quando o livro foi lançado. Eles parecem estar ligados uns aos outros apenas porque constituem as memórias de infância de um mesmo sujeito. A fragmentação, todavia, não esconde totalmente a progressão cronológica. A obra tem início com a primeira recordação, como é bastante comum em gêneros autobiográficos, e termina com a entrada na adolescência, marcada por dois amores: Laura e a literatura.

A obra memorialista de Graciliano compreende ainda Memórias do cárcere (2008). Publicado em 1953, o livro tem grande afinidade com Infância, principalmente pela atitude do narrador em relação ao passado, marcada pela desconfiança.

\subsection{Pedro Nava}

\subsubsection{As três identidades do discurso autobiográfico: uma comparação entre Baú de ossos e Galo-das-trevas}

Do primeiro (Baú de ossos) até o quarto volume (Beira-mar) da obra de Pedro Nava, reconhecemos, sem maiores dificuldades, o efeito de identidade entre o enunciador, o narrador e o ator do enunciado, o que é característico das obras autobiográficas, conforme já mostramos. A classificação genérica da obra - "memórias" -, que aparece na capa, já sugere para o leitor a identificação entre as instâncias mencionadas.

$\mathrm{O}$ efeito de identidade entre $\mathrm{o}$ ator do narrado e o enunciador é garantido, principalmente, pelo nome, Pedro Nava, reconhecido na capa como autor e, no interior da obra, como ator do narrado, a personagem. Em Baú de ossos, na primeira de suas duas dedicatórias, lemos ${ }^{13}$ :

\footnotetext{
${ }^{13} \mathrm{O}$ livro apresenta duas dedicatórias. Na primeira, o autor homenageia alguns amigos e, principalmente, os parentes falecidos e na segunda, seus amigos e sua esposa, Antonieta Penido, apresentada pelo apelido, Nieta.
} 
À memória de

PEDRO DA SILVA NAVA e ANA CÂNDIDA PAMPLONA NAVA FEIJÓ

meus avós

JOSÉ NAVA e DIVA JAGUARIBE NAVA, meus pais;

ALICE NAVA SALLES $e$

ANTÔNIO SALLES meus tios;

JOSÉ HIPÓLITO NAVA RIBEIRO meu sobrinho;

ALICE DE LUNA FREIRA minha prima;

GASTÃO CRULS, JOAQUIM NUNES COUTINHO CAVALCANTI $e$ RODRIGO DE MELO FRANCO DE ANDRADE, meus amigos.

PROFUNDAMENTE

Além de já introduzir o leitor no mundo dos mortos, que vai ocupar boa parte das Memórias, a dedicatória também reforça a identidade entre o enunciador, ao qual se atribui a responsabilidade de escrevê-la, e o ator do narrado. O nome dos familiares ("JOSÉ NAVA e DIVA JAGUARIBE NAVA"), acompanhado da relação de parentesco ("meus pais") com esse enunciador, permite que o enunciatário, ao longo da leitura, reconheça esses mesmos atores como parentes e amigos do Pedro Nava, Pedro ou Pedrinho, como é chamado $o$ ator do narrado.

Outros recursos vêm reforçar tal identificação, como o relato da produção de obras por parte do ator do narrado, que o enunciatário identifica como sendo da autoria de Pedro Nava, enunciador. É o caso de seu conhecido poema "O defunto", publicado mais tarde na Antologia de poetas bissextos brasileiros contemporâneos, organizada em 1946 por Manuel Bandeira: "Foi nesse sótão que mais tarde, a 23 de julho de 1938, dum jato, rejeitei de mim ' $O$ defunto"' (GT, p. 452). 
Além disso, a interdiscursividade também corrobora a produção da identificação, permitindo ao enunciatário, com seu conhecimento a respeito do autor, originado da leitura de biografias, reportagens e notícias, estabelecer certa correspondência entre a vida narrada nas Memórias e aquela que aparece nos outros discursos. Salientamos que a interdiscursividade apenas pode fortalecer um efeito localizável no interior da obra, a não ser que se queira ler qualquer texto como autobiográfico, sem levar em conta o que as marcas discursivas sugerem. É nesse sentido que afirmamos que a interdiscursividade vai tornar ainda mais eficaz o efeito de identidade entre enunciador e ator do narrado, mas ela não será neste trabalho tomada como critério único para o estabelecimento desse efeito.

A identificação entre o enunciador e o narrador, em Nava, realiza-se por meio da embreagem de pessoa, que confunde os níveis do enunciador e do narrador. Isso faz com que o enunciatário atribua a responsabilidade pelo que é dito tanto ao narrador quanto ao enunciador. Conforme já foi comentado, a presença de uma espécie de prólogo assinado é muitas vezes responsável pela produção de semelhante efeito. $\mathrm{Na}$ obra de Pedro Nava, não há esse "prólogo". Entretanto, em toda a primeira parte de Galo-das-trevas, além de explicar a aparição de Egon, o alter ego, o narrador justifica a escritura das Memórias. Nessa parte, que se destaca do todo da obra, encontramos o narrador falando, predominantemente, do aqui e do agora da narração. Para o espaço temos seu apartamento no bairro da Glória, no Rio de Janeiro: "Estou escrevendo no meu escritório, olhando lá fora o dia molhado, frio e gris que cobre o Aterro (GT, p. 5)". Para o tempo, temos como data inicial o dia 5 de junho de 1978: "É o que penso no dia em que completo setenta e cinco anos de vida e começo este meu quinto volume de memórias" (GT, p. 5). Segundo Aguiar, esse capítulo é de fundamental importância para o leitor da obra literária de Nava, pois constitui uma interrupção do fio narrativo que vinha se desenrolando, além de ser também uma parte de transição (entre narradores e entre protagonistas, conforme veremos adiante):

[...] em "Jardim da Glória" o tempo é puxado para o presente, para o ato de sua escritura, compreendendo, sem dúvida, a passagem de maior subjetividade das Memórias. O capítulo é uma espécie de ponto de chegada, a partir do qual o caminho se bifurca novamente, abrindo 
espaço para a continuação da narrativa, que já não será exatamente a mesma. No "Jardim da Glória" se dá o encontro do eu que narra com o escritor. É, portanto, o primeiro grande momento de confissão, explícita, por assim dizer, das Memórias (1998, p. 47).

Assim, essa parte pode ser lida como uma grande embreagem actancial, em que narrador e autor implícito surgem sobrepostos. Ao longo da obra, encontramos outras passagens do mesmo tipo que merecem atenção, como quando o narrador, comentando um dos filmes assistidos pelo ator do narrado Egon, detém-se no recurso cinematográfico do close-up e diz já ter tratado do tema em livros anteriores: "Já discuti a questão da descoberta do close-up em livro anterior" (GT, p. 200). Podemos mencionar ainda o final de Galo-dastrevas, quando é anunciada a publicação do próximo volume das Memórias. Nesses dois casos, o narrador se apresenta como o autor dos livros.

Rio de Janeiro, Glória, 5 de junho de 1978 - 19 de outubro de 1980.

\begin{tabular}{c} 
Gostou de MEMÓRIAS / $5 ?$ \\
Pois aguarde para breve MEMÓRIAS / 6 e a segunda \\
parte deste livro designada: \\
O CíRIO PERFEITO \\
Galo-das-Trevas / 2 \\
\hline
\end{tabular}

(GT, p. 441)

O efeito de identificação entre o narrador e o enunciador pode ser fortalecido pela debreagem enunciativa da enunciação: "quando os actantes da enunciação estão projetados no enunciado" (FIORIN, 1996, p. 117). Tal procedimento é reconhecido por meio da leitura das marcas de primeira pessoa (do singular ou do plural) ou de segunda, como se nota nas primeiras palavras de Baú de ossos, quando o narrador indica suas origens: "Eu sou um pobre homem do Caminho Novo das Minas dos Matos Gerais" (BO, p. 5). A explicitação do narratário é menos frequente. "Pensam que acabou?" (GT, p. 314), pergunta o narrador no meio de uma extensa descrição da rotina de Dona Diva Jaguaribe Nava (mãe de Pedro Nava).

As marcas enunciativas não garantem a identificação entre enunciador e narrador, mas reforçam-na. Afinal, mesmo um narrador que fala explicitamente em primeira pessoa pode ser construído de forma a diferenciar- 
se do enunciador. Há inúmeros exemplos em nossa literatura, sendo um dos mais célebres talvez o narrador de Dom Casmurro (2008), de Machado de Assis, obra em que o leitor reconhece Dom Casmurro como narrador e não Machado de Assis, embora tal narrador seja projetado por meio de uma debreagem enunciativa da enunciação.

$O$ efeito de identidade entre o narrador e o ator do narrado pode ser criado por diferentes recursos, mas em Pedro Nava prevalece a utilização da debreagem enunciativa do enunciado (ator do narrado é um eu) ${ }^{14}$. É o que se verifica no momento em que o narrador descreve os passeios feitos com tio Salles num tempo passado, quando ainda era um menino:

Ainda com tio Salles subi um dia as ladeiras da Rua do Morro, onde morava não sei mais que amigo seu. Enquanto ele parava, no alto, para olhar a vista escampa e larga que dali se descortina - Santa Teresa, o Corcovado e a Tijuca levantando a cara e o nariz pico - eu atentei num pano de muro branco todo cheio de inscrições e desenhos pornográficos. Esse gênero de criação plástica é sempre levado a efeito com a pressa inspirada aos autores pelo medo de um flagrante e a pressa obriga-os a sínteses essenciais, às vezes tão fabulosas que só podem ser comparadas a certos close-ups, relances e gags achados pela suscetibilidade de um cinegrafista de gênio. Tal era o esboço que vi - que guardei de memória, como coisa perturbadora, posto que então incompreensível (BO, p. 369).

Nesse fragmento, é possível identificar o eu do narrado, que aparece em "subi" ou "eu atentei" e o eu da narração, que reconhecemos em "não sei". Se os tempos diferenciam o narrador - instaurado no presente da narração do protagonista - instaurado no passado do narrado -, o pronome pessoal os identifica (STAROBINSKI, 1970, p. 261-262). É preciso dizer ainda que os diferentes procedimentos para a criação dos efeitos de identidade no discurso autobiográfico fortalecem uns aos outros.

A partir de Galo-das-trevas, essa questão das identidades torna-se ainda mais complexa. Conforme já mostramos, o livro está dividido em duas partes: "Negro" e "O branco e o marrom". Na primeira, em que o narrador trata de seu presente ao longo de uma interminável noite que se aprofunda no tempo da

\footnotetext{
${ }^{14} \mathrm{O}$ caso de Galo-das-trevas e de $\mathrm{O}$ círio perfeito, obras em que o narrador passa a relatar a vida de Egon, será considerado mais adiante.
} 
memória, reconhecemos a identificação entre enunciador, narrador e ator do narrado, de que tratamos.

\section{"Negro"}

- Enunciador: Pedro Nava

- Narrador 1: Pedro Nava (debreagem enunciativa da enunciação - eu)

- Protagonista: Pedro Nava (debreagem enunciativa do enunciado - eu)

É na página 100 de Galo-das-trevas, ainda nessa primeira parte, que o narrador fala sobre o dia em que, logo depois do café, recebeu um embrulho de seu primo Egon, já apresentado em volumes anteriores. Em Galo-das-trevas, o primo é descrito como "sósia, primo, amigo de infância, colégio, faculdade, vida, profissão afora" (GT, p. 79). Egon, ou Doutor José Egon Barros da Cunha, é mostrado como o primo inseparável de Pedro Nava: "mineiro de Santo Antônio do Desterro - outrora Vila Nova d'El-Rey de Santo Antônio do Desterro no Mato Grosso das Minas - nos dias dagora Santo Antônio do Desterro ou só Desterro" (GT, p. 79).

Segundo o relato, o embrulho trazia cinco pastas de cartolina e uma carta, em que Egon explicava que pretendia "desaparecer da vida social, na tolice como ela é entendida hoje" (GT, p. 101). Mudaria para um asilo, onde não desejava ser incomodado até a morte. Deixava para seu primo, Pedro Nava, manuscritos, fotos e documentos: suas memórias. É esse rico material que o narrador afirma constituir a base da história que tem início na segunda parte do livro.

Assim termina o trecho intitulado "Negro". Em "O branco e o marrom", começa, então, o relato que teria sido feito a partir dos manuscritos de Egon. Logo nas primeiras páginas, notamos uma mudança com relação ao narrador.

Para adiantar um pouco o caso, vamos contar que vários dias depois, voltando da zona tifenta, o Egon fora à casa da sua paciente (GT, p. 121: grifos nossos).

Mas... deixemos de conversa fiada e voltemos aos dois amigos (GT, p. 201: grifos nossos). 
Já descrevemos seu aspecto físico mas devemos voltar às qualidades morais que o completavam como a um ser absolutamente excepcional (GT, p. 297; grifos nossos).

O narrador que se utiliza sempre da primeira pessoa do singular (narrador 1) dá lugar, a partir da página 103 de Galo-das-trevas, a um segundo narrador (narrador 2), que se utiliza da primeira pessoa do plural. $O$ narrador 1 , responsável por passar a palavra a esse segundo narrador, não desaparece por completo em "O branco e o marrom". Salvo engano, ele aparece duas vezes no corpo do texto da parte 2 de Galo-das-trevas. Além disso, é o responsável pela organização do narrado e é a voz dele que reconhecemos nas notas:

\footnotetext{
* Nesse subcapítulo noto que foi citado várias vezes o grande Couto. Talvez seja a necessidade de lembrar um nome de nossa Medicina que não deve ser olvidado. Não posso nunca esquecer da pergunta que ouvi, há bem seus muitos anos, de interno meu - sextanista - que diante de minha insistência em citar aquele médico perguntou-me "Mas Doutor Nava, afinal quem era esse Miguel Couto em quem o senhor tanto fala?" isso se passou com um doutorando de 1949 apenas quinze anos depois da morte desse que, a seu tempo, era o maior médico brasileiro - a própria encarnação da Clínica Médica Brasileira... Preste-se ao menos atenção ao fato de existirem no Rio uma rua e um hospital com o nome ilustríssimo (Nota de Pedro Nava) (p. 377, nota).
}

Já discuti a questão da descoberta do close-up em livro anterior (GT, p. 200).

Assim como para o Falcão de Valadares quero repetir também alguma coisa sobre o Percival de Aquino (GT, p. 297).

A distinção que se estabelece na obra entre o narrador da primeira parte e aquele da segunda é então marcada no enunciado. Mas quem seria esse nós, ou seja, o narrador 2? Pedro Nava, José Egon, um narrador que não é personagem? Para o crítico literário Joaquim Aguiar, ele se constitui como um narrador de tipo romanesco, de terceira pessoa, que surge como resposta a uma busca por um distanciamento maior em relação à matéria relatada ${ }^{15}$ :

\footnotetext{
${ }^{15}$ A crítica literária, normalmente, considera narrador em terceira pessoa o narrador que não é personagem, mesmo que se utilize da primeira pessoa do plural. O nós aparece diversas vezes
} 
A partir de Galo-das-trevas não teremos mais o mesmo narrador que vinha conduzindo a história, mas um narrador de tipo romanesco. Ele deixa de ser protagonista, cedendo lugar à figura de Egon Barros da Cunha, que seria seu primo. [...] Resumindo o esquema geral do narrador das Memórias é o seguinte: até Galo-das-trevas é grande a proximidade entre a voz que narra e a matéria narrada. A partir desse volume, crescendo 0 grau de distância entre 0 narrador e 0 protagonista, aumenta o terreno da ficção, explicando-se, assim, as investidas romanescas de Nava no final da obra. O narrador transformase em personagem secundário que relata e testemunha as aventuras da vida do seu alter ego. É como se a escrita se libertasse do rumo autobiográfico que vinha seguindo, tomando ali o atalho da pura ficção (AGUIAR, 1998, p. 20).

Benveniste (1966) mostra que há apenas duas pessoas do discurso, o eu (aquele que fala) e o tu (com quem se fala), que formam uma categoria oposta à da não-pessoa, o ele (sobre o que se fala, o assunto). A marca de plural e de feminino correspondem à não-pessoa, já que as pessoas do discurso não se pluralizam. Retomando o que diz o linguista francês, Fiorin (1996, p. 60) evidencia que a primeira pessoa e, na maior parte dos casos, a segunda, quando em sua forma plural, são antes pessoas amplificadas que pluralizadas. Logo, o nós não indica a "multiplicação de objetos idênticos, mas a junção de um eu com um não-eu" (FIORIN, 1996, p. 60).

O nós pode representar a soma da primeira pessoa com a segunda $(e u+t u)$, ou da primeira pessoa com a não-pessoa (eu+ele) ou ainda da primeira com a segunda e a não-pessoa $(e u+t u+e l e)$. Nos três casos, não temos, então, uma somatória de "eus" ou uma multiplicidade de enunciadores. O nós pode ser ainda empregado no lugar do eu - estamos no domínio da embreagem -, é o que se chama plural majestático, de modéstia ou de autor. Conforme explica Fiorin (1996, p. 96), os efeitos resultantes dessa embreagem são diversos. O eu pode ser amplificado, como em discursos de autoridades, em que se tem o plural majestático. No plural de modéstia, o efeito é de enfraquecimento da subjetividade do eu. No caso do plural de autor, utilizado em obras como as científicas, o eu se apresenta como falando em nome de uma comunidade, o que lhe confere certa autoridade e distanciamento maior 
do que o que temos com o uso da primeira pessoa do singular. Perguntamonos, então, a qual desses usos do nós corresponde o que encontramos na segunda parte de Galo-das-trevas.

Numa primeira leitura, a expectativa que se cria, ao final de "Negro", é que a narração continue a ser feita por Pedro Nava ou que seja assumida por José Egon, como um interlocutor que se avoluma no interior do texto. No entanto, ao lermos com mais cuidado a passagem que encerra essa primeira parte, notamos que vamos deparar com mais opacidade:

Que eu lesse a papelada que ele mandava e onde deixara consignada a estória de sua passagem pela Medicina. E fizesse com ela o que entendesse. Se estivesse uma merda, fogo. Se servisse... Abri e fui tomando conhecimento do que continham as cinco pastas. Eram centenas de folhas manuscritas ora em forma de narrativa, ora de diário, cartas, telegramas, fotografias de família e fotografias obscenas, recortes de jornal, desenho de casas em que morara, notas de suas viagens pelo mundo, às vezes só uma palavra mágica num quadrado de papel, às vezes citações copiadas dos livros que lera, páginas arrancadas deles, recibos, prospectos, recortes de faits-divers, de convites para missa, participações de falecimento, casamento, nascimento, receitas de remédio e receitas de doces. Havia escritos em papel de carta, de telegrama, margens de jornal, avesso de volantes, papel de cópia, de carta, ofício, almaço. Havia de tudo. Pus em ordem cronológica, depois, nos entreperíodos datados, os fatos mostrados, apontados, flagrados ou comentados, relacionei com estes os documentos fotográficos e de lembranças que eram coevos e fascinado com o que me oferecia a vida do amigo, resolvi transformá-la na narração que se vai ler sob o título de $O$ branco e o marrom. E o que me assombra é que a existência do Egon era carbono, uma espécie de xerox da minha. De tal maneira que a continuação de minhas memórias se tornou inútil diante da publicação que vou promover das do primoamigo. Com a vantagem de serem mais bem escritas do que eu seria capaz de o fazer - meu parente sempre tendo mostrado especial vocação para as letras, desaproveitada devido a sua eterna desvalorização de si mesmo. Ele e a sua papelada me restituíram um passado tão congênere que sua busca do tempo perdido era a minha. Sua existência foi a minha e a minha continua a ser a de José Egon Barros da Cunha. Quando ele me faz saudades e quero suas novas fecho os olhos, penso - logo ELE existe (GT, p. 101-102: grifos nossos).

O narrador, identificado a Pedro Nava, aparece como aquele que organizaria a "papelada", supostamente recebida de seu primo, transformandoa em narração; logo ele poderia continuar em seu papel de narrador. 
Entretanto, ele afirma, ao mesmo tempo, que as memórias de Egon são mais bem escritas do que as suas, motivo que o leva a abrir mão de continuar o relato de sua própria vida para falar da do primo. Assim, não fica claro se ele assumirá ou não a narração da segunda parte da obra; pelo contrário, a passagem citada apenas alimenta a dúvida.

O leitor pode pensar que as relações entre o narrador e os atores do narrado, em "O branco e o marrom", serão esclarecedoras, pois aquele que for chamado por um eu (Egon ou Nava), no nível do narrado, poderá ser identificado ao narrador. Entretanto, tanto a Pedro Nava quanto a José Egon se faz referência por meio da terceira pessoa (a não-pessoa: ele). O primeiro a aparecer no texto é Egon, ator do narrado em torno do qual gira a narrativa a partir dessa passagem. Pedro Nava surge algumas páginas adiante:

O Doutor José Egon Barros da Cunha abriu as janelas e o dia sol entrou de roldão (GT, p. 107).

Seus amigos estavam lá dentro, o Ari sentado à escrivaninha e, meio reclinado na giratória de mola, dirigia-se ao Nava montado na única cadeira ali existente, braços cruzados sobre seu encosto. O primeiro era moço de seus trinta anos, dando a impressão de muito magro, porque seu rosto era fino e mais ainda o nariz que se alongava e que era caráter marcante de sua fisionomia. [...] O outro era o primo e amigo do Egon, formado com ele há menos de um mês (GT, p. 111).

Durante toda essa parte, o narrador não deixa de fazer menção às anotações deixadas por Egon, de forma a misturar ainda mais as vozes de Nava e do primo:

As notas deixadas pelo Egon referentes a esse período e postas em ordem por Pedro Nava mostram que ele assistiu ao seu espetáculo de lançamento, sempre no Avenida e sempre com os mesmos companheiros (GT, p. 399).

As notas mandadas por Egon a Pedro Nava e donde ele tirou essa narrativa, estão cheias de reflexões do primeiro sobre o assunto. [...] Os cheiros do macho ou da fêmea são viceversamente afrodisíacos. Nesse caso o dos pés deve ter o mesmo papel do dos genitais. Compreendase nessa afirmativa do Egon o cheiro normal, não corrompido pela idade, doença e pela prisão nas sapatrancas e nas botinas em que aparece - como as infecções que são favorecidas nas cavidades fechadas (GT, p. 368-369). 
Dando um salto para o futuro, suas notas escritas dos anos setenta deixavam consignadas suas longas conversas nesse desacontecido porvir com seu primo Pedro Nava - em que os dois faziam as contas das manhãs em que não tinham vivido - mas em que suas vidas tinham sido literalmente dadas aos outros [...] (GT, p. 258).

Saudosos amigos. Uns perdidos de vista, outros permanecendo afeição fiel da vida inteira, a maioria desaparecida no grande sono... Saudade. Mas alguns deles não são apenas de referência. Nas suas notas, apontamentos, diários - o Egon dedicou-lhes palavras demoradas (GT, p. 279).

Só o vestido merecia uma festa. Nunca o Egon tinha visto, jamais veria nos tempos futuros coisa mais linda. Nas notas tiradas por ele e de onde é tirada a narrativa dessa festa, contava que ao vestido aplicavase palavra que ele descobrira numa leitura francesa: froufroutantes (GT, p. 250).

Temos, assim, um narrador que usa a primeira pessoa do plural para se referir a si mesmo e que insere os atores do enunciado (Nava e Egon) na narrativa por meio da terceira pessoa. Logo, o leitor não tem como ter clareza a respeito de quem está narrando essa segunda parte do livro: se Pedro Nava, se José Egon. O nós pode ser compreendido como um eu+ele (Nava+Egon; ou Egon+Nava), o que parece bem provável devido ao que é dito no final da primeira parte de Galo-das-trevas, ou como um plural de autor - logo, uma embreagem - em que o nós é empregado no lugar do eu (Nava ou Egon) para criar algum distanciamento ou ainda o efeito de amplificação. O nós pode ainda abrigar o tu, o narratário, passando a ser formado por eu+ele+tu. Embora esse uso seja menos marcado, há algumas passagens que permitem dizer que o narrador se identifica também ao narratário. Isso ocorre quando ele comenta a própria narração: "Mas é tempo de voltarmos ao Clube do Desterro" (GT, p. 251).

Também não há indícios que permitam definir se os atores do enunciado são discursivizados por meio de uma debreagem enunciva ou de uma embreagem enunciva. Se o narrador é Pedro Nava, logo referir-se a si mesmo na terceira pessoa constitui uma embreagem enunciva do enunciado e referirse a Egon na terceira pessoa constitui uma debreagem enunciva do enunciado. O mesmo vale para Egon, caso ele seja o narrador. Quando Egon se refere a si 
mesmo na terceira pessoa, está utilizando o recurso da embreagem enunciva; quando se refere a seu primo, Pedro Nava, por meio da terceira pessoa, o recurso da debreagem enunciva.

O fato de os atores do narrado serem instituídos por meio de marcas enuncivas produz o efeito de objetividade e afastamento do narrador com relação à matéria narrada. $O$ enunciador também se distancia, já que a "cascata" de identificações parece parcialmente interrompida. Assim, temos para essa segunda parte:

\section{"O branco e o marrom"}

- Enunciador: Pedro Nava.

- Narrador 1: Pedro Nava (debreagem enunciativa da enunciação - eu). Ele aparece nas notas, na "capa" do capítulo e em sua organização.

- Narrador 2: Pedro Nava ou José Egon (debreagem enunciativa, o que é mais provável, ou embreagem enunciativa).

- Atores do narrado: Pedro Nava e José Egon (debreagem enunciva do enunciado e embreagem enunciva do enunciado, não necessariamente nessa ordem).

Com isso, em Galo-das-trevas e depois em $O$ círio perfeito, vemos subvertida uma das convenções principais do discurso autobiográfico: a identificação entre enunciador e narrador, narrador e protagonista, e protagonista e enunciador. A sintaxe discursiva, especialmente com relação à actorialização, faz com que o leitor não possa afirmar com certeza se essas identificações se realizam nesse discurso ou não. Se o narrador 2 é Egon, produz-se o efeito de identificação entre o narrador 2 e o protagonista Egon, mas fica desfeita a identificação entre esse narrador 2, o narrador 1 e o enunciador. Nesse caso, essas duas obras autobiográficas aproximar-se-iam do romance "ficcional", o que parecia ser o desejo de Pedro Nava, conforme bem observou Aguiar (1998), já que, se o narrador 2 é Egon, há um narrador que aparece explicitamente como uma criação ficcional e que se diferencia do enunciador. Se o narrador 2 é Pedro Nava, as identidades se mantêm, embora Pedro Nava na segunda parte do livro se torne personagem secundária, o que também gera um estranhamento em relação às coerções genéricas, pois a vida que ele narra é e não é a sua. A ambiguidade produzida na relação entre o 
narrador 2 e os atores do narrado leva, então, a reler o livro, problematizando a questão das identidades.

enunciador $=$ narrador 1

narrador $1=$ ou $\neq$ narrador 2

narrador $2=\mathrm{e} \neq$ atores do narrado

enunciador $=\mathrm{e} \neq$ atores do narrado

As crônicas publicadas como anexo no final da obra apenas fortalecem as dúvidas deixadas para o leitor. A primeira, "Residências no Rio", que trata de período posterior ao abordado em Galo-das-trevas, constrói as identidades de acordo com o que observamos na obra de Nava até a primeira parte desse quinto volume. Na segunda, "Peixe vivo", o narrador 2 toma a palavra mais uma vez para falar de quando Egon ouviu as letras para "Peixe vivo" criadas por Manuel Bandeira, Vinícius de Moraes, Pedro Nava e outros.

Quando deixei Oeste Paulista, vim para o Rio, onde cheguei a 10 de março de 1933 (GT, Anexo I, p. 445).

Foi quando minha Mãe mudou-se de Belo Horizonte para o Rio e alugamos o apartamento 302 da Rua Laranjeiras número 382 (GT, Anexo I, p. 452).

Quando o Egon foi ao Tijuco com Gudesteu de Sá Pires, com Fábio Andrada, Pedro Aleixo [...] (GT, Anexo II, p. 453).

A ambiguidade criada pela sintaxe discursiva é mantida na semântica. Se a presença de dois atores do narrado indica tratar-se de duas entidades distintas - Egon e Pedro Nava -, ao longo do livro, o leitor encontra inúmeras pistas que apontam para a identificação entre eles. O primeiro elemento que chama a atenção é o nome escolhido para o primo, como vemos em excerto retirado da primeira parte do livro, quando temos o narrador 1 :

Pela física ou pela química do mais apelativo, meu parente e amigo é chamado Doutor Egon ou só Egon - para os íntimos. Sempre fomos inseparáveis e sabíamos tudo um do outro. Essa intimidade, esse conhecer das qualidades e defeitos recíprocos muitas vezes nos trazia 
entediados e doutras chegava a nos dar um nível de aborrecimento resvalando para a hostilidade. Mas não adiantava e terminávamos nos suportando, agüentando, espécie de gostando - na tolerância duma intimidade compulsória que só a morte pode destruir. Pois nossa convivência foi sendo cada vez mais lúcida - sobretudo agora, no tempo de nossa vida de velhos em que a introspecção permite a cada, julgamento mais profundo do outro. $E$ temos franquezas luminosas, julgamentos atilados e tão cruéis que fazemos papel de consciência nos momentos mais impecáveis de nossa convivência. Um capítulo sobre esta xifopagia intolerável, essencial, imprescindível - bem poderia trazer na portada as palavras de Chamberlayne que Edgar Allan Poe tomou como epígrafe do seu "William Wilson". Lembram?

Que dirá ela a respeito? Essa CONSCIÊNCIA hedionda, Espectro com que tropeço em todos os caminhos?

Mas nem sei se vale a pena penetrar nesses dédalos do sentimento. Basta que se saiba que o Egon e eu somos inseparáveis, mais que amigos, alteregos, mútuos (GT, p. 80).

"Egon" já contém a palavra "ego" dentro de si, sugerindo no nome próprio a ideia de alter ego, ou seja, de um outro, que é ao mesmo tempo um eu ou ainda de um outro centro de personalidade e, por que não, de um outro centro da percepção. Além disso, o narrador, por meio de expressões diferentes, não se cansa de ressaltar que o primo corresponde a um alter ego: classifica a relação deles como uma "xifopagia intolerável, essencial, imprescindível", mostra que um faz o papel de consciência do outro, afirma que são "inseparáveis, mais que amigos, alteregos, mútuos". Na página 102 de Galo-das-trevas, diz que "sua busca do tempo perdido era a minha. Sua existência foi a minha e a minha continua a ser a de José Egon Barros da Cunha" e ainda que a existência de Egon é "carbono", "xerox" da sua. Ao finalizar a primeira parte de Galo-das-trevas, brinca com a máxima de Descartes, "Penso, logo existo", mas substitui a primeira pela terceira pessoa, criando uma correspondência entre o eu (Pedro Nava) e o ele (José Egon): "Quando ele me faz saudades e quero suas novas - fecho os olhos, penso logo ELE existe" (p. 102).

Ao afirmar que sabiam tudo um do outro, que "a introspecção permite a cada, julgamento mais profundo do outro" (p. 80), mostrando que a introspecção, ou seja, o fechamento dentro de si aproxima-o ainda mais de 
Egon, o narrador retoma ideia apresentada em algumas páginas anteriores. A escritura de suas memórias e a penetração no mais fundo de sua alma correspondem ao mergulho dentro de "outro" homem: Egon. Ou seria de si mesmo?

Conversando comigo, nessa espécie de falar sozinho é que no dia $1^{\circ}$ de fevereiro de 1968 comecei a redigir minhas lembranças. Por elas reduzi ao mínimo minha convivência até com amigos, até com os que mais quero, para não fragmentar e destruir meu tempo, o tempo de que preciso para mim. E essa fase foi a da punção como num poço, a penetração a fundo de outro homem como eu, outro misantropo e eterno esnobado, vivendo vida de exílio dentro do nosso próprio país. Refiro-me ao que tem sido meu companheiro cada vez mais chegado, meu sósia, primo, amigo de infância, colégio, faculdade, vida, profissão afora (GT, p. 79).

Inclusive a Egon é atribuída a responsabilidade pela continuidade das Memórias, não só porque os manuscritos pertencem a ele, mas porque, antes disso, ele já influenciara Pedro Nava a retomar o trabalho. Segundo o narrador, Egon sugere-Ihe que utilize a pena como arma contra aqueles que the fizeram mal, ao invés de partir para alguma outra forma de violência: "Use suas armas. Você não está? escrevendo suas memórias. Pois pregue estas pústulas lá, no pelourinho que você lhes armar" (GT, p. 98).

Além disso, na segunda parte do livro, as semelhanças entre Pedro Nava e Egon são colocadas em evidência, pelo narrador 2, diversas vezes. Enquanto Egon é enviado para trabalhar como médico em Santo Antonio do Desterro, que seria sua terra natal, Pedro Nava vai para Juiz de Fora, lugar em que nasceu. O "pseudônimo" escolhido para Juiz de Fora, "Desterro", já anuncia as desventuras do rapaz em sua cidade de origem. Ele não encontra nela o acolhimento desejado. A sociedade é descrita como fechada e muito conservadora. Aqueles que querem prosperar devem curvar-se ante os poderosos e, principalmente, beijar o anel do bispo. O jovem passa antão a ser um desterrado em sua terra. O narrador não deixa de enfatizar o espelhamento entre as vidas dos primos, mostrando que o Desterro poderia muito bem ser Juiz de Fora: 
De repente lembrou o primo amigo que estava em Juiz de Fora, Pedro Nava. Recebera carta dele que falava da cidade, dividindo-a em duas: a da direita de quem descia a rua Halfeld - bem-pensante, ultramontana, dos homens do poder e do dinheiro - e a da esquerda - contrincante, irreligiosa - dos intelectuais e da gente de nada que vive de pada e água. Pensando bem ele bem que podia aplicar essa idéia ao Desterro que era cortada em duas partes pela Rua Schimmelfeld (GT, p. 286).

Procedimento semelhante identificamos quando Egon decide chamar sua prima Diva, mãe de Nava, de mãe-prima, confundindo os papéis. Se Dona Diva pode ser sua mãe, Egon poderia também ser seu filho, ou seja, o Nava:

- Prima Diva, acho que dagora em diante vou começar a tratar você do jeito dos filhos da prima Zoleta. Vou chamar também de Mãe. Só que para ficar diferente deles vou conservar o prima. Mãe-prima fica ótimo (GT, p. 325).

Outra passagem que merece ser comentada diz respeito à autoria do poema "O defunto", atribuída a Egon nesse momento, mas a Pedro Nava em outros, como no segundo Anexo de Galo-das-trevas: "Foi nesse sótão que mais tarde, a 23 de julho de 1938, dum jato, rejeitei de mim 'O defunto'” (GT, p. 452).

Exatamente nove anos depois, completar-se-ia a gravidez de "O Defunto" e o primo Egon escreveria na noite lancinante da Urca o poema que o habitara desde a infância (GT, p. 370).

Além disso, trata-se de um poema que ganhou certo reconhecimento, foi publicado na antologia organizada por Manuel Bandeira. Logo, o leitor identifica esse poema como de Pedro Nava. Não há dúvidas, o enunciador, por meio de uma série de artimanhas discursivas, pretende que o enunciatário reconheça a identidade aproximativa, na semântica discursiva, entre os atores Nava e Egon.

Todos esses recursos para criar a equivalência entre os primos fortalecem a construção do ator José Egon como um alter ego, um ser reveladamente de papel. Enfatizamos o advérbio "reveladamente", pois não queremos fazer a oposição entre Pedro Nava e José Egon (atores do narrado) corresponder a uma oposição do tipo real vs. ficcional. É pertinente, no entanto, mostrar que a própria obra faz com que o enunciatário reconheça o Egon como 
uma criação discursiva, enquanto para Pedro Nava isso nem sempre ocorre. $\mathrm{O}$ narrador afirma, referindo-se a seu duplo: "Quando ele me faz saudades e quero suas novas - fecho os olhos, penso - logo ELE existe" (GT, p. 101-102). Mostra-se assim como aquele que poderia ter inventado o primo-amigo.

A partir de Galo-das-trevas, é intensificado o uso de pseudônimos, algo que já aparece em outros volumes, mas neste até as cidades são batizadas de novo. Apesar disso, o leitor das Memórias facilmente reconhece os nomes como sendo pseudônimos, não se trata de enganá-lo. Isso porque o pseudônimo, na obra de Nava, geralmente é construído como algo que não é nem parece o nome "real". É possível para o leitor identificar os atores já mencionados nos outros volumes, por meio de sua caracterização, da relação de parentesco e mesmo de alguma semelhança fonética dos nomes: os tios Felisberta e Colatino, por exemplo, são Berta e Palleta. Além disso, geralmente os pseudônimos são criados a partir de nomes pouco usuais e que condensam o julgamento do enunciador a respeito do ator nomeado, principalmente quando a avaliação não é favorável ${ }^{16}$. Os colegas de profissão são os alvos principais da pena afiada do "escritor". É o caso do "Dr. Eutanásio Boamorte" e do "Dr. Sacanagildo Goiaba". Nem sempre o leitor será capaz de saber a quem se referem aqueles nomes, mas ele poderá rir um riso mordaz junto com o enunciador que faz assim a crítica desejada. Isso apenas reforça o aparecimento de Egon como máscara sob a qual se esconde Pedro Nava. Poderíamos, então, pensar que na semântica discursiva José Egon Barros da Cunha desempenha papéis tão afins com Pedro Nava que é criado o simulacro da simbiose identitária entre eles.

No entanto, essas observações não são suficientes para compreender os efeitos de sentido produzidos pela existência discursiva de Egon. José Egon é Pedro Nava, mas também não é Pedro Nava. Para construir o ator Egon, são utilizados recursos que criam o efeito de que ele possui uma existência até certo ponto autônoma: Egon existe dentro da obra. Ele tem genealogia própria, cidade natal e até mesmo características que o distinguem de Nava:

\footnotetext{
16 “Por medida de precaução, os elogiáveis são tratados por seus nomes e os desprezíveis por pseudônimos, todos esquisitos, já contendo em si o traço caricaturesco com que aparecerão: Rosalvo Tranquilino, Cloacário Barata, Josino Rasposo, Alegrino Chuerba, Preposto Concórdia, Variolandopiteco Tucunduva, etc." (AGUIAR, 1998, p. 149).
} 
Falei dele no Chão de Ferro e no Beira-Mar. É que no Pedro II e Faculdade de Medicina de Belo Horizonte era conhecido como Zegão e que depois de formado passou a ser Doutor José Egon Barros da Cunha, mineiro de Santo Antônio do Desterro - outrora Vila Nova D’EI Rey de Santo Antônio do Desterro no Mato Grosso da Minas - nos dias dagora Santo Antônio do Desterro ou só Desterro (GT, p. 79).

Sempre gostei de ver a aptidão dos dois para a Medicina. A vocação servida em cada um por qualidades diferentes. Em você, Nava, pela criatividade e inventividade, em você, Egon, pela capacidade de análise e de crítica (Elogios tecidos por um antigo professor: GT, p. 112).

Quem conquista coração é senhor do corpo. Amado. E viva ele na sua beleza. Era a teoria do Zegão. E quem era? esse Zegão. Nem mais nem menos que meu arquiparente e amigo como os que mais. Arquiparente, por quê? Ele era neto do Desembargador Egon de Barros Palácio e de dona Doralice Barroso Pamplona, ambos primo-irmãos de minha avó paterna. Esse juiz, ao tempo da magistratura móvel, servira na Relação de Ouro Preto onde sua filha Raimundinha de Barros Palácio conhecera o estudante de Farmácia João Elisário Pinto Coelho da Cunha que era primo-irmão de minha avó materna. Foram os pais de José Egon Barros da Cunha, aliás Zé Egon, aliás Zegon (em casa) e aliás Zegão no Externato do Colégio Pedro II. Nós éramos assim primos três vezes e cada um possuía três sangues do outro. Por um capricho genético tínhamos saído cara dum focinho do outro. Era de confundir. [...] Com uma diferença. Ao contrário de mim o Zegão era atirado, audacioso e chegado a elas. Não tinha a minha timidez (CF, p. 227).

Logo, a semântica discursiva constrói a identificação de José Egon e Pedro Nava no modo da ambiguidade, confirmando o que encontramos por meio da análise da sintaxe do discurso. É preciso dizer ainda que essa ambiguidade é constitutiva dessa obra e fundamental para a produção de seu sentido, daí o interesse em explicar por meio de quais mecanismos ela se produz no interior do discurso. Afirmar que Egon é Nava, sem qualquer problematização, seria desconsiderar a própria obra que trabalha com a incompletude, a incerteza, questionando a concepção de discurso autobiográfico como reprodução do real. A obra autobiográfica é, assim, apresentada como criação. Daí talvez se possa extrair alguma verdade dessas páginas. Ao modo do clichê, José Egon "afirma" que "A vida é um romance sem enredo (De um manuscrito de José Egon Barros da Cunha)" (GT, p. 103), aproximando literatura e vida. A existência de Egon pode, então, ser entendida como uma forma de discutir o estatuto do próprio discurso autobiográfico, dado 
no gênero literário romance, algo que o narrador já vinha fazendo ao longo da obra.

\begin{abstract}
Afastando-se para a terceira pessoa, o escritor buscava evidenciar o perfil ficcional de suas Memórias. Ocorre, entretanto, que a providência tomada não faz subir o nível estético dos livros. Ao contrário, como tem observado a crítica, a qualidade da obra tende a cair nos últimos dois volumes (AGUIAR, 1998, p. 147).
\end{abstract}

Essas observações apontam para a possibilidade de compreender o uso da primeira pessoa do plural por parte do narrador e ainda o uso do sistema enuncivo para referir-se aos atores do narrado. Conforme o narrado parece aproximar-se do presente da narração, ocorrem algumas mudanças: a história passa a ser contada pelo narrador 2, apresentado por meio de marcas enunciativas de pessoa (nós); Pedro Nava, ator do narrado, perde seu lugar de protagonista e passa a ser discursivizado por meio do sistema enuncivo; Egon tona-se o protagonista, ainda que apresentado por meio de marcas enuncivas de pessoa. O efeito é não só de embaralhamento na semântica (em relação à construção dos atores) e na sintaxe (em relação à instalação de pessoas no enunciado), mas também de distanciamento dos fatos narrados em relação à enunciação. Além disso, embora muitas indicações permitam criar a identificação entre Egon, o novo protagonista das Memórias, e o enunciador, a discursivização da pessoa, feita de forma labiríntica, distancia um do outro.

Se podemos dizer que a escritura autobiográfica permite o surgimento de um eu, de um éthos, que se constitui ao longo do processo da escrita, Egon parece materializar no texto uma parte desse eu. Ele aparece em Chão de ferro e vai ganhando espaço até tornar-se o protagonista e suposto narrador das Memórias, como se o próprio Nava se tornasse esse outro, ao qual se identifica e do qual se diferencia ao mesmo tempo.

Maingueneau (2005) estabelece uma diferenciação gradual entre 0 éthos dito e o éthos mostrado. O primeiro é construído a partir daquilo que o enunciador "fala" de si mesmo, de referências diretas e explícitas; o segundo, que na verdade estaria mais próximo do que vem sendo tratado como éthos na semiótica (DISCINI, 2003), é reconstituído a partir de um modo de dizer, de recorrências textuais e discursivas. Podemos depreender o alter ego como uma 
concretização, feita por meio do ator do enunciado, do éthos dito: a parte que o enunciador quer mostrar de si mesmo, mas sem ter que se preocupar com as imposições sociais de modéstia que geralmente incidem sobre aqueles que falam de si. As estratégias empregadas para a criação do alter ego, essa espécie de éthos dito, contribuem ainda para a projeção do éthos mostrado.

\subsubsection{Memória e amplitude}

O passado é o tempo forte dos romances autobiográficos de maneira geral, isso significa que é o tempo dominante nas obras que realizam tal gênero e, em grande parte, constitui-se também como uma época melhor, o que justifica a rememoração. Em Nava, especialmente a infância vivida em Rio Comprido é recordada como um período de maior completude:

Manuel Bandeira que era amigo do rei, ia-se embora pra Pasárgada. Ai! De mim, sem rei amigo nem amigo rei, que quando caio no fundo da fossa, quando entro no deserto e sou despedaçado pelas bestas da desolação, quando fico triste, triste (“...Mas triste de não ter jeito...”), só quero reencontrar o menino que já fui (BO, p. 293).

As figuras do "deserto" e do corpo "despedaçado" dão concretude à falta de unidade e de sentido experimentadas pelo narrador no presente. Se a infância e a adolescência constituem momentos de descobertas e de novas experiências cheias de significado, sendo aspectualizadas pela incoatividade; o momento em que se encontra o narrador é terminativo.

É a memória que pode restabelecer a continuidade com o passado. Vista de forma mais ampla que a faculdade de lembrar, a memória em Nava pode ser reconhecida em tudo aquilo que permite recuperar o tempo perdido. Sobre uma resposta de Heitor Modesto feita a um inquérito de Gilberto Freyre, quando este estava preparando Ordem e progresso, o narrador afirma:

Tive-a em mãos e é um pouco de lembrança, um pouco pelas referências de Gilberto Freire, que rememoro o que ali se dizia das casas comissárias, onde os donos exerciam autoridade de chefes, de 
proprietários, mas também uma espécie de influência paternal e abacial sobre a fraternidade monástica dos empregados (BO, p. 57).

Em sua primeira noite no "Desterro", chega às mãos de Egon o Álbum Municipal do Desterro, evidentemente um livro que traz a versão oficial da história do município e que deixa de lado as origens pouco confessáveis da tradicional família mineira. A obra é lida pelo jovem médico com desconfiança e sarcasmo (GT, p. 164-167). Assim, além das lembranças, vão fazer parte da memória monumental do narrador e do ator do narrado: cartas antigas, testamentos, certidões, fotografias, livros, artigos de jornais, mapas, histórias contadas por familiares e amigos, anotações, etc. São vozes incorporadas de maneira polêmica ou contratual que contribuem para apresentar o passado como uma totalidade, sem deixar quase ver suas lacunas, cavadas pelo esquecimento; algo bem diverso do que encontramos em Graciliano, como será mostrado. Mesmo os objetos e móveis guardados, como aqueles do apartamento da Glória, são parte integrante da memória do narrador, mesmo as construções, as ruas: "Aqui é a Avenida Brasil. Também não. Aqui era o porto onde encostava a lancha de Oswaldo Cruz vindo para a Fazenda de Manguinhos" (GT, p. 7). Em seus passeios pelo Rio de Janeiro, o narrador reconhece os lugares que marcaram tanto sua história pessoal (as casas frequentadas na infância, por exemplo), quanto a história da cidade ou do país, sem deixar de lado o Rio, espaço literário: "onde passou o vulto de Capitu" (GT, p. 7). O narrador evidencia que, para reconhecer na cidade a sedimentação das experiências passadas, é preciso um árduo trabalho:

Para saber essas coisas é preciso ler muito, prestar atenção às conversas, perder dias inteiros indo verificar um número de casa, ou conseguir a façanha de consultar uma coleção de jornais na Biblioteca Nacional (GT, p. 7).

Notamos, pois, que há uma intencionalidade guiando a reconstrução do passado. Assumindo o papel quase de um historiador, ele vai em busca de documentos que the permitam desvendar e entender essas outras camadas de tempo escondidas sob a tinta do presente, tornando-as linguagem. Para ele, essas outras fontes podem servir tanto para completar sua memória de alguma experiência vivida quanto para recriar um passado 
que não conheceu diretamente, como a infância dos avós e bisavós ou ainda o surgimento da cidade do "Desterro". Mesmo não tendo participado de forma direta desses momentos, eles o constituem. Essa intencionalidade não direciona apenas o trabalho do "pesquisador", pois também aparece quando o narrador busca rememorar voluntariamente experiências passadas:

Na recordação voluntária não podemos forçar a mecânica com que as lembranças nos são dosadas. Os fatos sumidos nos repentes, em vez de todos, em cadeia, voltam de um em um. Às vezes, um só. Esse se oferece para suprir e vicariar os que as defesas do psiquismo acham que não é hora de dar e ele é uma espécie de 'em vez de' acontecimento, imagem que tem de ser coagida pelo consciente, para soltar outros, outros e nos dar aparência do integral não achado, mas construído (tiririca de que é preciso forçar o minúsculo pé, para fazer sair da terra os metros de raízes ocultas que ligavam moitas emergentes e distantes). Às vezes não adianta violentar e querer lembrar (BO, p. 292).

Retomando Proust, autor citado inúmeras vezes ao longo da obra de Nava, o narrador fala de duas memórias, a voluntária e a involuntária. A memória voluntária funciona, na superfície do discurso, de modo apenas metonímico. O narrador explica seu método de trabalho comparando-se a Curvier, que de um dente reconstrói a besta, ou a um arqueólogo, que de uma curva refaz o vaso. Assim, o passado é reconstruído voluntariamente a partir de fragmentos que permaneceram dele no presente. Já a memória involuntária age inicialmente por uma operação metafórica. Ela estabelece relações de semelhança ${ }^{17}$. O sabor da rapadura feita pela avó de Nava, bem como outras sensações presentes, desperta a lembrança de sensações similares experimentadas no passado.

Para que esse outro tempo venha à tona, o sujeito recordador precisa, então, entrar em contato com algum elemento presente capaz de fazer

\footnotetext{
${ }^{17}$ Nossa análise fundamenta-se nas propostas de Fiorin (2008), que, com base no legado da Retórica Clássica e nas ideias de Jakobson (1963) e de Hjelmslev (1975), mostra que a metáfora e a metonímia, dois mecanismos de conotação, não concernem apenas à palavra isolada, mas podem ser compreendidas como procedimentos discursivos. De Jakobson, recupera a ideia de que a metáfora e a metonímia são regidas, respectivamente, pelas relações de similaridade e contiguidade, algo já proposto pela Retórica Clássica. De Hjelmslev, traz as noções de não pertinência da dimensão das unidades de manifestação na definição do signo e de semiótica conotativa.
} 
desencadear uma série de associações sensoriais. Entre os estímulos possíveis, aqueles que despertam o sentido da visão são os mais explorados em Nava, embora cheiros, sabores, texturas e sons também possam atrair os blocos de memória para a superfície do presente e, assim, do texto. A partir desse estímulo, as imagens do passado emergem no campo de presença do sujeito como um acontecimento, entendido aqui em sua acepção tensiva. Para dar conta desses conceitos, faremos uma breve digressão teórica.

A existência, em semiótica, é pensada a partir da categoria da presença, uma vez que essa teoria não está interessada em emitir juízos ontológicos sobre a natureza dos objetos em análise:

À teoria semiótica se coloca o problema da presença, isto é, da "realidade" dos objetos cognoscíveis, problema comum - é verdade - à epistemologia científica no conjunto. Nesse nível, ela pode contentar-se com uma definição operatória que não a compromete em nada, dizendo que a existência semiótica de uma grandeza qualquer é determinada pela relação transitiva que, tomando-a como objeto de saber, a liga ao sujeito cognitivo (GREIMAS; COURTÉS, 2008, p. 194-195).

Para Fontanille e Zilberberg, seria preciso dar um passo a mais em relação à noção de existência proposta no Dicionário de semiótica e "reconhecer, em tal relação cognitiva, a base perceptiva de toda a significação" (2001, p. 124). Os autores propõem, então, que a semiótica herde da fenomenologia e, mais especificamente, de Merleau-Ponty a noção "de campo de presença". Tal como vem sendo trabalhado numa perspectiva tensiva, o campo de presença pode ser compreendido, por um lado, como: "o domínio espácio-temporal em que se exerce a percepção, e, por outro, as entradas, as estadas, as saídas e os retornos que, ao mesmo tempo, a ele devem seu valor e Ihe dão corpo" (FONTANILLE; ZILBERBERG, 2001, p. 125). Toda grandeza que penetra no campo é avaliada a partir de sua extensão e ainda da intensidade da percepção de um sujeito. A dimensão da extensidade, que subsume as subdimensões da temporalidade e da espacialidade, ocupa-se dos "estados de coisas", correspondendo ao inteligível. A subdimensão da temporalidade possui como oposição básica abreviação vs. alongamento, enquanto a espacialidade organiza-se por meio da oposição concentração vs. expansão (ZILBERBERG, 2006b, p. 230 e 237). Já a dimensão da intensidade, 
que possui a tonicidade e o andamento como subdimensões, corresponde à medida do afeto que nos toca em nossa relação com o mundo, ou seja, aos "estados de alma", ao sensível. A tonicidade fornece a oposição básica tônico vs. átono e o andamento, a oposição rápido vs. lento (ZILBERBERG, 2006b, p. 236 e 239). A afetividade é assim trazida para o centro da teoria, como revela Zilberberg:

[...] longe de apenas admitir, como que a contragosto, a afetividade, circunscrevendo-a à modesta função de adjunto adverbial de modo, preferimos acolhê-la, sob a denominação de intensidade, como grandeza regente do par derivado da esquizia inaugural (2006a, p. 169).

É preciso dizer ainda que, para Zilberberg, a intensidade constitui-se como a dimensão regente e a extensidade, como a dimensão regida. Se a intensidade diz respeito à força com que somos afetados pelas grandezas que penetram nosso campo de presença, a extensidade diz respeito à extensão temporal, em primeiro lugar, e também espacial do campo controlado pela intensidade.

Nessa perspectiva, torna-se relevante recuperar a noção de acontecimento, tal como concebida por Zilberberg (2007b). Visto como o sincretismo entre o andamento e a tonicidade, que compõem o eixo da intensidade, o acontecimento é aquilo que surpreende o sujeito, que satura seu campo de presença, e que, num primeiro momento, é ininteligível. Pode apenas ser sentido. Corresponde a um aumento do andamento e da tonicidade, mas não a um aumento lento, processual, e, sim, brusco, como um salto. Há uma aceleração, percebida como a entrada súbita de uma dada grandeza no campo de presença, muito antes que se pudesse prever sua chegada. A tonicidade também é elevada ao seu grau máximo, uma vez que o sujeito é tomado em sua integralidade pelo acontecimento e sente seu impacto. O termo correlato do acontecimento, o exercício (ZILBERBERG, 2007b), configura-se como aquilo que se opõe a tudo isso. Como mostra o gráfico apresentado a seguir, ele corresponde à lentidão e ao mínimo impacto. 


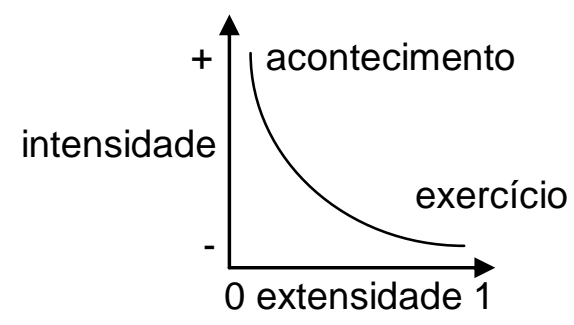

O sujeito que vive o acontecimento, experiência de ordem afetiva, não é um sujeito do agir, mas aquele que suporta, que sofre seus efeitos. Trata-se de um sujeito de estado e não de um sujeito operador. Com relação ao que Zilberberg (2007b) nomeia modo de eficiência, que é a maneira pela qual uma grandeza se instala num campo de presença, o acontecimento corresponde à modalidade do sobrevir, que significa dizer que a grandeza se instala no campo de presença sem nenhuma espera, e o exercício à do pervir (conseguir, chegar a), que se dá quando o processo é efetuado segundo o desejo do sujeito ${ }^{18}$. $O$ sobrevir e o pervir são regidos pelo andamento.

Com relação ao que o autor define como modo de junção, ou seja, a condição de coesão pela qual um dado é ou não afirmado, o acontecimento, que institui o inusitado, funcionaria de acordo com o modo da concessão (embora $a$, no entanto $b$ ), já que ele subverte a causalidade postulada pela implicação (se $a$, então $b$ ), que é a lógica do exercício.

O acontecimento realiza, então, a integração entre o sobrevir e a concessão, já o exercício une o pervir e a implicação. De posse desses conceitos, podemos, agora, retomar a análise. Na passagem citada a seguir, o narrador descreve-se observando - já adulto - a casa de sua infância:

Manuel Bandeira que era amigo do rei, ia-se embora pra Pasárgada. Ai! De mim, sem rei amigo nem amigo rei, que quando caio no fundo da fossa, quando entro no deserto e sou despedaçado pelas bestas da desolação, quando fico triste, triste (“...Mas triste de não ter jeito...”), só quero reencontrar o menino que já fui. Assim, quantas e quantas vezes viajei, primeiro no espaço, depois no tempo, em minha busca, na de minha rua, na de meu sobrado...Custei a recuperá-lo. Aviltado pelos anos e reformas sucessivas, recoberto de uma camada de cimento fosforecente e pó de mica, que tinha substituído o velho revestimento e

\footnotetext{
${ }^{18}$ O termo original "parvenir" vem sendo traduzido por "pervir" por Luiz Tatit, Waldir Beividas e Ivã Carlos Lopes.
} 
o ultramar da pintura da fachada - não havia meios da recordação provocada entregar-me a velha imagem. Foi preciso o milagre da memória involuntária. Eu tinha ido me refugiar na rua maternal, tinha parado no lado ímpar, defronte do 106, cuja fachada esbatia-se na noite escura. Olhando as janelas apagadas. Procurando, procurando. De repente uma acendeu e os vidros se iluminaram mostrando o desenho, trinta anos em mim adormecido. Acordou para me atingir em cheio, feito bala no peito, revelação - como aquele raio que alumbrou São Paulo e fê-lo desabar na Estrada de Damasco. Na superfície fosca, alternavamse quadrados brilhantes, cujos cantos se ligavam por riscos octógonos. Essa luz prestigiosa e mágica fez renascer a casa do fundo da memória, do tempo; das distâncias das associações, da lembrança. Como ela era! com suas janelas abertas ao vento, ao calor, às manhãs, aos luares. Foi aquele tumultuar, aquele entrechoque arbitrário de diversidades se conjuntando em coisa única: consubstanciaram-se as ferragens caprichosas da frente, os dois lances da escada de pedra, bicos de gás da sala de jantar, as quatro figuras de louça da varanda (Primavera, Verão, Outono, Inverno), um velho oratório, o baú cheio de ossos, o gradil prateado, o barulho da caixa d'água, o retrato da prima morta, o forro de couro macio das espreguiçadeiras, o piano preto e o cascalhar de suas notas e escalas ao meio-dia, os quartos, os ângulos do telhado, os rendados de madeira da guarnição do frontispício, silêncios, risos, tinidos de talher, frescuras de moringas de barro, vozes defuntas em conversas outrora, murmúrio noturno das ondas do rio Comprido, avencas e begônias, minha Mãe convalescendo, meu Pai chegando, minhas tias, as primas - tudo, tudo, todos, todos se reencarnando num presente repentino; outra vez palpável, visível, magmático, coeso, espesso e concentrado - tal a súbita franja feita por limalha de ferro atraída pela força dum ímã. À luz daquela janela, ao fanal daquela vidraça! Ponto crioscópico fazendo cristalizar a velha casa há tanto diluída e surgir sua fachada antiga e juvenil em lugar da que eu tinha diante de mim, máscara mortuária cheia de cicatrizes como as de um rosto que se tivesse desfigurado com a espadana de um pote de vitríolo. Eu olhava deslumbrado quando o automóvel parou e ouvi as gargalhadas de Maria do Carmo e José Nabuco perguntando que semvergonhice eu estava fazendo? naquele bairro, naquela rua, àquela hora. Ri também, consentindo. Como é que eu poderia explicar? que estava ali completando oito anos de idade e que meu Pai, indagora! ressurgia dos mortos para me dar nossa casa nova em folha... Nela eu entro, na velha casa, como ela entrava nos jamais. Esse portão... (BO, p. 289-290).

Vemos nesse trecho a ruptura instaurada pelo acontecimento, que é a própria memória involuntária atingindo em cheio o sujeito, como "um raio". Todo o seu campo de presença é tomado - "de repente" ou de forma "súbita" 
(expressões que mostram o andamento acelerado) - pela visão do sobrado da infância, a ponto de o sujeito não notar a chegada do automóvel com seus amigos. O narrador inclusive sente dificuldade de explicar o ocorrido, afinal é ele que é apreendido pelo passado, não é algo que controle. É como um "milagre", que o narrador aprecia "deslumbrado", o que revela o recrudescimento da tonicidade. A brevidade do tempo e o fechamento do espaço, correspondentes a uma extensidade quase nula, aparecem figurativizados em expressões como: "presente repentino", "palpável, visível, magmático, coeso, espesso e concentrado", "súbita franja feita por limalha de ferro atraída pela força dum ímã" e ainda em " ponto crioscópico", que cristaliza a casa antes "diluída", ou seja, perdida na extensidade do tempo e do espaço e, por isso, pouco tônica para o sujeito ${ }^{19}$.

A sequência de sintagmas, com rarefação do elo explícito da conjunção coordenativa, produz para o sujeito da enunciação o mesmo impacto e velocidade sentidos pelo ator do enunciado diante do sobrado da infância:

[...] consubstanciaram-se as ferragens caprichosas da frente, os dois lances da escada de pedra, bicos de gás da sala de jantar, as quatro figuras de louça da varanda (Primavera, Verão, Outono, Inverno), um velho oratório, o baú cheio de ossos, o gradil prateado, o barulho da caixa d'água, o retrato da prima morta, o forro de couro macio das espreguiçadeiras, o piano preto e o cascalhar de suas notas e escalas ao meio-dia, os quartos, os ângulos do telhado, os rendados de madeira da guarnição do frontispício, silêncios, risos, tinidos de talher, frescuras de moringas de barro, vozes defuntas em conversas outrora, murmúrio noturno das ondas do rio Comprido, avencas e begônias, minha Mãe convalescendo, meu Pai chegando, minhas tias, as primas [...] (BO, p. 290).

A significativa redução de emprego das conjunções conduz, então, a uma leitura célere. A estrutura que se repete, sem encaminhar-se para qualquer resolução, gera a sensação de acúmulo, mesmo tipo de acúmulo que observamos na duplicação dos pronomes indefinidos "tudo" e "todo", que

19 No Dicionário Houaiss (2009), a "crioscopia" é definida como: "técnica que permite medir o abaixamento do ponto de congelamento de líquidos causados por substâncias dissolvidas, que determina propriedades físicas como a massa molecular do soluto e a concentração e a pressão osmótica da solução". No Dicionário de usos do Português do Brasil (2002) lemos: "Crioscópico: Adj (Classificador de nome não-animado) [relativo a] congelamento produzido em líquidos por substâncias nele dissolvidas". O termo parece então reforçar a ideia de concentração. 
já se apresentam como num grau de força máxima. É como se tudo o que fosse lembrado tivesse que ocupar o mesmo ponto espaçotemporal, a mesma pequena fratura aberta no presente. A ênfase dada aos sentidos, especialmente à visão, coloca enunciador e enunciatário em meio àquele "entrechoque arbitrário de diversidades". O narrador fala do prateado do gradil, do barulho da caixa d'água, do pretume do piano e do som de suas notas, da maciez do couro das espreguiçadeiras, etc. Não é possível para o enunciatário formar uma imagem clara da casa, pois ela é dada a ver quase que apenas por aspectos sensoriais, de forma metonímica. A lembrança interpela os sentidos, os afetos, não fornecendo contornos nítidos; por enquanto, é pura intensidade. A aparição de figuras humanas é feita por verbos no gerúndio ("minha Mãe convalescendo, meu Pai chegando"), incialmente sua presença é indicada apenas pelos sons que produzem ("risos", "tinidos de talher", etc). O uso do gerúndio, somado à falta de localização temporal, produz para o sujeito da enunciação o efeito de que a cena ocorre fora do tempo.

A rememoração, nesses casos, pode ser aproximada dos momentos de estesia, analisados por Greimas em Da imperfeição (2002). Quando as lembranças irrompem no presente daquele que se lembra, é instaurada uma ruptura em relação à vida representada. Verifica-se no texto uma mudança no modo de constituir tanto as isotopias, quanto o espaço e o tempo. Um universo em que se verifica o enfraquecimento de cores, sons, cheiros e formas dá lugar a uma casa densa sensorialmente. O sujeito, arrebatado pela imagem do passado, experimenta, por um breve instante, uma sensação de suspensão do tempo e do espaço, devido à aceleração no eixo da intensidade e à compressão da extensidade. Nesses momentos, o sujeito é tomado pelo objeto numa relação dada pelos sentidos que subjetiva o objeto, tornando-o agente, e apassiva o sujeito, já que são as imagens do passado que se lançam sobre aquele que se recorda, completando-o: "Que significa isso, senão que a apreensão estética aparece como um querer recíproco de conjunção, como um encontro no meio do caminho, entre o sujeito e o objeto, no qual um tende rumo ao outro?" (GREIMAS, 2002, p. 34). O momento de plenitude, "perfeição entrevista", deixa saudades. 
Esses instantes em que uma brecha se abre no cotidiano do sujeito recordador, produzindo a visão extraordinária, são regidos pela lógica concessiva, própria do acontecimento. Em outras passagens, o reencontro dos valores do objeto (passado) resulta das competências modais do sujeito. Seja por meio da rememoração voluntária, seja por meio da pesquisa de documentos e livros de história, o narrador, no modo do pervir, faz outros tempos surgirem na linguagem. Subjaz a essa forma voluntária de fazer aparecer o passado a lógica implicativa do exercício, que diz respeito à previsibilidade. Entretanto, há inúmeras vezes, como confessa o narrador, em que ele não consegue realizar o que havia planejado. Chama a memória, mas o único a lhe responder é o esquecimento.

Para que o passado venha à tona e possa ser revivido, o narrador procura esquecer-se de seu presente, ele quer retomar o menino que foi. Marc Augé define, em Les formes de l'oubli (1998), três figuras do esquecimento, uma delas é o retorno, cuja ambição primeira é reencontrar um passado perdido por meio do esquecimento do presente - logo, também do passado imediato - para restabelecer uma continuidade com esse passado mais antigo. Ele apresenta, como ilustração do retorno, certos rituais de possessão da África e da América. O antropólogo mostra que, na América, como na África - por meio de formas rituais distintas -, aquele que foi possuído por um espírito, um ancestral ou um deus vive a presença de um outro em si mesmo, ou de um outro si mesmo. Para que isso ocorra, é preciso esquecer o presente e todos os lapsos de tempo que se confundem com ele. Parret, comentando o livro de Marc Augé, afirma: "É pelo esquecimento do presente que o retorno pode restabelecer a continuidade com o passado mais antigo" (2006, p. 99; tradução nossa) ${ }^{20}$. Acrescentamos que aquele que se esquece do presente, esquece-se momentaneamente - e talvez não por completo - de si mesmo no presente. Assim, se há um esquecimento do passado que encerra o sujeito que procura se lembrar e não consegue em seu presente, há, na reminiscência, o esquecimento do presente para que o passado se torne presença novamente para o sujeito

\footnotetext{
20 "Et c'est par l'oubli du présent que le retour est en état de rétablir une continuité avec le passe le plus ancien".
} 
recordador. Logo o esquecimento, combatido na obra de Nava por afastar o passado, constitui a outra face da memória involuntária.

A partir da categoria da presença, podemos trabalhar com a coexistência de duas grandezas - no caso, o presente e o passado - e de suas entradas e saídas no campo perceptivo do sujeito. O esquema ora apresentado permite visualizar os diferentes modos da existência semiótica, a partir da organização sintagmática da categoria presença/ausência (FONTANILLE; ZILBERBERG, 2001, p 134) com os termos propostos por Tatit $(2010 \text {, p. } 58)^{21}$ :

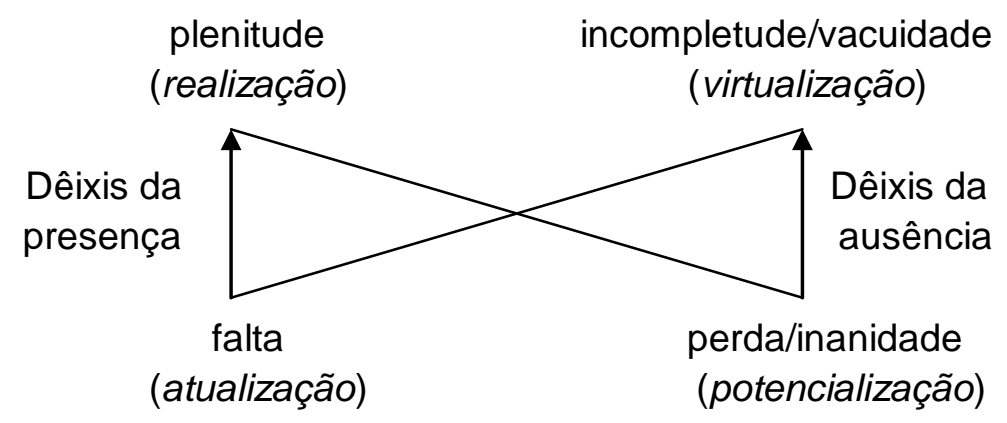

O percurso que leva da realização à potencialização e, por fim, à virtualização corresponde a uma perda de densidade existencial, que permite ao fato ser memorizado (potencialização), para em seguida talvez ser esquecido. No sentido contrário, da virtualização para a atualização e, por fim, para a realização, acontece um ganho de densidade existencial, ou seja, a coisa fica mais presente para o sujeito. É o que se passa durante a rememoração, embora não seja o fato em si que retorna, mas um simulacro no qual estão investidos valores atrelados ao passado. No caso de Nava, são valores eufóricos. O sobrevir das lembranças tem como contraparte um enfraquecimento brusco do presente para o sujeito recordador - o narrador ou o ator do narrado: o presente é potencializado. É nesse sentido que podemos falar de uma ausência da presença.

Ao mesmo tempo, as lembranças, ou seja, as imagens do que não existe mais adentram o campo de presença do sujeito, atualizando ou

${ }^{21}$ A primeira representação gráfica da categoria da presença é realizada em Semiótica das paixões (GREIMAS; FONTANILLE, 1993, p. 52), em que é proposto um quadrado semiótico para articular os modos de existência. Ele foi depois revisto em Tensão e significação (FONTANILLE; ZILBERBERG, 2001, p, 131). 
realizando valores do passado. Assim, podemos falar de uma presença da ausência. É isso que leva Hajji-Lahrimi (1999, p. 77), em seu estudo sobre Proust, a afirmar que a reminiscência estabelece uma relação de concessão entre a presença e a ausência. É como se a aceleração e a tonicidade com que o objeto aparece enfraquecessem momentaneamente as competências cognitivas do sujeito, torna-se mais difícil para ele saber que está no presente, tempo em que o passado é vivido como falta. "A apreciação [do objeto estético] é então de ordem tátil e não cognitiva" (2002, p. 36), diz Greimas. Mas a fusão entre homem e mundo dura pouco, trata-se de um encontro fugaz, delimitado pelo próprio cotidiano, logo o sujeito se dá conta novamente da perda do passado.

Nas Memórias, diversos recursos discursivos e linguísticos são empregados para produzir o efeito de sobreposição dos tempos. Em Baú de osso, observamos a recorrência das embreagens temporais que substituem os tempos enuncivos pelos enunciativos.

Para mim, roçar os dentes num pedaço de batida é como esfregar a lâmpada de Aladim - abrir os batentes do maravilhoso. Reintegro imediatamente a Rua Aristides Lobo, no Rio; a Direita, em Juiz de Fora; a Januária, em Belo Horizonte - onde chegavam do Norte os caixotes mandados por Dona Nanoca com seus presentes para os netos. Docemente mastigo, enquanto uma longa fila de sombras vem dos cemitérios para tomar o seu lugar ao sol das ruas e à sombra das salas amigas: passam lá fora o Coronel Germano e a Dona Adelina Corroti numa conversa de palavras sem som. Meu pai entra sorrindo e seus pés não fazem barulho na escada. Minha mãe chega em silêncio e tira duma jarra um molho de cravinas translúcidas para pôr no coque. A vida recomeça como a projeção (no vácuo!) de um filme de cinema mudo.

O céu, sem uma nuvem é lindo e desolado como um deserto. Pesa o sol a pino despejando luz tão branca e densa que se tem a impressão de vê-la descer em lenta pulverulência. O calor do meio-dia seria insuportável sem o vento que não pára. Ele entra pelas portas e janelas abertas - em corrente, em tromba, em golpes, em lufadas e rodamoinhos e numa de suas rajadas chega o moreno amado, vestido de claro, colarinho largo e o vasto chapéu Manilha que lhe empastou, na testa, a cabeleira revolta. É hora da sesta e do café depois da metade do seu trabalho (BO, p. 27).

Ao morder a batida feita por sua avó - espécie de rapadura que costumava comer quando menino -, o narrador vive uma "invasão" de figuras 
que povoavam um outrora. Utiliza o tempo presente ("passam", "entra", "fazem", "chega", "tira”, etc) no lugar do pretérito perfeito 2 e do pretérito imperfeito, criando o efeito de subjetividade e ainda de aproximação do passado em relação à enunciação (FIORIN, 1996, p. 207-208) ${ }^{22}$. A sequência de orações coordenadas, por um lado, ajuda a compor a lembrança como bloco único, formado por relações de contiguidade; por outro, caracteriza o texto descritivo e produz o efeito de que o narrador descreve o que vê, o que acontece diante de seus olhos, reforçando a presentificação. A metáfora do "filme de cinema mudo" corrobora nossas afirmações. Embora o início desse fragmento de memória possua uma organização narrativa (quanto ao tipo textual), já que dispõe os fatos numa sequência temporal, ele está sob o domínio da descrição, que constrói no texto a maneira como os eventos são percebidos. As ações desenvolvem-se, no geral, de forma concomitante. Especialmente no segundo parágrafo citado, a ênfase recai sobre as qualidades dos objetos. Bertrand, ao refletir sobre os diferentes tipos de texto a partir da questão do ponto de vista, afirma: "No discurso descritivo, o ponto de vista se refere diretamente à atividade perceptiva" (2003a, p. 114). Mostra assim a relação muito próxima que existe entre a atividade perceptiva e a descrição nos discursos.

Da segunda parte de Galo-das-trevas em diante, o narrador - narrador 2 - não se mostra mais como aquele que se lembra, mas como alguém que relata uma história vivida no passado, assim, as embreagens que trazem o narrado para a narração saem de cena. Os momentos de recordação ainda aparecem, mas em concomitância com tempos enuncivos, como quando Egon se recorda do baile de carnaval a que assistiu ainda menino, no Clube do Desterro:

Ele conservara uma impressão feérica como a de uma cascata de jóias - luzeiro em movimento - faíscas presas dentro duma bola de gaze que tivesse a consistência e o apanhado dum casulo de bicho-de-seda. Ele

\footnotetext{
${ }^{22}$ Em outras línguas românicas, como o francês, há um tempo específico para marcar a anterioridade com relação ao presente (passé composé) e outro, a concomitância com relação a um momento de referência pretérito (passé simple). Isso não ocorre em português, o que leva Fiorin (1996, p. 152) a chamar pretérito perfeito 2 o tempo verbal concomitante ao momento de referência passado, distinguindo-o do pretérito perfeito 1 , que corresponde à anterioridade no sistema enunciativo.
} 
via o espetáculo de fogo por dentro, quando se intrometia entre as pernas e caudas dos pares dançando. Via de fora quando se deitava sobre as cadeiras de mogno preto que circulavam o salão (GT, p. 176).

Para criar o efeito de sobreposição dos tempos, o narrador lança mão de outras estratégias, como a repetição do verbo "ver", algo que não é exclusivo do trecho citado. $O$ efeito é de que as cenas antigas, vividas num pretérito mais-que-perfeito, ocorrem novamente diante do ator do narrado, Egon. O narrador descreve o que o jovem médico enxerga, e aquilo que ele vê ganha consistência, textura, o que está em acordo com as palavras de Bertrand: "A visão, voltada para o exame detalhado das qualidades sensoriais, parece retornar à sua forma elementar e primitiva: o tato" (2003a, p. 137). Em Nava, recordar com certeza é ver, não apenas com os olhos, mas com todo o corpo. O sujeito recordador toma parte na cena lembrada. O uso de verbos no pretérito imperfeito, que apresentam o evento em sua duração, como se apreciado de dentro, reitera tal efeito (FIORIN, 1996, p. 155).

É preciso dizer ainda que, embora a memória possa aparecer de forma repentina, causando surpresa, é possível alguma preparação. Notamos em certas passagens que o sujeito busca em seus passeios pelas diversas cidades onde morou o contato com elementos que fizeram parte de seu passado e que podem despertar suas lembranças latentes. Cada vez que Egon refaz o caminho que levava de sua casa ao Centro de Saúde, em Belo Horizonte, na zona da Mantiqueira, e coloca os pés nas calçadas pavimentadas de ladrilho ocorre uma "ressurreição":

Até hoje quando o Egon põe seus velhos passos nestes ladrilhos vai chamando mentalmente os antigos moradores das casas quase todas mortas e de que algumas milagrosamente estão de pé balizando e dando distâncias exatas e lugares certos para o das recordações - que de chofre se erguem, como em filme de terremoto rodado às avessas. $E$ o médico só passa hoje, ali, de alma antiga e com desejo de saudar pessoas e casas com o bom dia! de antanho (GT, p. 324).

Portanto, embora as explosões de memória ocorram inopinadamente e sem o controle do sujeito, observa-se que há uma preparação que é feita e que pode ser frustrada ou não. Nada garante que o toque dos ladrilhos trará de volta os mortos chamados por Egon, mas, como isso já ocorreu outras vezes, 
ele pode esperar que o fenômeno se repita. Vemos algo semelhante também em Baú de ossos, quando o ator do narrado, Pedro Nava, coloca-se à procura do sobrado da infância. O narrador afirma que, tomado pela tristeza, vai ao encontro da casa maternal ("Procurando, procurando."), quando de repente uma das janelas se acende. É o início do "milagre". Em todos esses casos, reconhecemos o que Greimas (2002) identifica como a "espera do inesperado".

O semioticista mostra que é do cotidiano banalizado e imperfeito, universo do parecer, que nasce aquilo que o ultrapassa: "A imperfeição aparece como um trampolim que nos projeta da insignificância em direção ao sentido" (GREIMAS, 2002, p. 91). Parret, retomando a reflexão de Greimas, afirma que "A fratura do cotidiano, a ruptura da isotopia da cotidianidade pelas irrupções do sublime, é isso que constituirá o cotidiano e o sublime como pólos de uma delimitação recíproca" (1988, p. 20; tradução nossa) ${ }^{23}$.

Ao tentar recriar as condições que possibilitaram a aparição do evento extraordinário, o sujeito, em Nava, procura ritualizar o cotidiano. Estabelece uma série de percursos, repetindo os passos dados no passado. $\mathrm{Na}$ análise de "As margens da alegria", conto de Guimarães Rosa, Tatit mostra que:

[...] aquilo que foi potencializado (presença transferida à memória), e na sequência virtualizado (presença latente), provoca o sentimento de falta (recomposição da presença) e a necessidade da renovação do encontro. Dentro desse sistema de presença, preserva-se o que podemos chamar de renovação das novidades, ou seja, renovam-se as chances de conhecimento mais apurado do "outro" e, ao mesmo tempo, cria-se um pequeno rito ("hábito", para alguns semioticistas) de reencontros, nos quais são aprofundados os valores que fazem do sujeito e do objeto uma só entidade (2010, p. 98-99).

O que o sujeito em Nava deseja encontrar são as "rimas", as correspondências entre as qualidades experimentadas no presente e aquelas do passado. É como se ele tentasse estabelecer uma relação com o mundo pautada por uma espécie de função poética da linguagem.

23 "La fracture du quotidien, la rupture de l'isotopie de la quotidienneté par l'irruptions du sublime, c'est ce qui constituera le quotidien et le sublime comme pôles d'une délimitation réciproque". 
Saussure observa que há dois tipos de relação entre os termos linguísticos, as relações sintagmáticas e as associativas, duas formas de atividades mentais: "A relação sintagmática existe in praesentia; repousa em dois ou mais termos igualmente presentes numa série efetiva. Ao contrário, a relação associativa une termos in absentia numa série mnemônica virtual" (1969, p. 143). Essas reflexões são depois retomadas por Jakobson, que, partindo dos dois modos básicos de arranjo utilizados no comportamento verbal, seleção e combinação, estabelece a função poética: "A função poética projeta o princípio de equivalência do eixo de seleção sobre o eixo de combinação" (1995, p. 130). Embora o linguista esteja pensando a princípio na linguagem verbal, ele estende as reflexões a respeito das operações de seleção e de combinação a outras semióticas (JAKOBSON, 1963). Barthes (1987) retoma essas ideias e analisa o vestuário, o cardápio, o mobiliário, a arquitetura, a partir de dois eixos: o sistema (eixo paradigmático) e o sintagma.

Nas Memórias, o sujeito recordador busca relações de semelhança na contiguidade do mundo, as "rimas". Eventualmente, ele as encontra, pois reconhece a similaridade entre as qualidades dos objetos presentes e aquelas dos objetos-simulacros que formam suas lembranças. Vive momentaneamente essa relação de semelhança entre duas grandezas in praesentia para ele, ainda que não segundo a mesma densidade de presença. $O$ momento da perfeição corresponde, então, a uma espécie de função poética experimentada no mundo imperfeito. As equivalências das qualidades do mundo homologamse às equivalências das sensações experimentadas pelo homem no presente e pelo menino no passado.

Tatit (2010), na análise já mencionada, explora a relação de pressuposição entre o cotidiano banal, englobante, e o mundo epifânico, englobado, buscando explicar as condições de emergência do acontecimento extraordinário ${ }^{24}$. Seu advento produz um desvio narrativo, fazendo com que o sujeito experimente um novo quadro de determinações. A partir da categoria da presença, o semioticista analisa o que ocorre com o destinador e o antissujeito. $\mathrm{O}$ antissujeito sai de cena, potencializado, para que seja possível a comunhão

24 "Trata-se, na verdade, de duas dimensões indissociáveis do mesmo acontecimento extraordinário: de um lado, ele nega os programas narrativos habituais do cotidiano e, então, define-se como 'fratura'; de outro, ele pressupõe os mesmos programas e define-se assim como 'escapatória'” (TATIT, 2010, p. 52). 
total com o objeto, enquanto um novo destinador é atualizado no discurso. $\mathrm{O}$ acontecimento extraordinário traz consigo novos valores, ou seja, valores que não faziam parte do cotidiano banal:

Ao não demonstrar qualquer hesitação no ato de reconhecimento do objeto, ou do valor do objeto, o sujeito deixa entrever que já possuía um destinador virtualizado, uma espécie de guardião dos valores utópicos, e que essa função ganha presença imediata assim que o sujeito toma consciência do evento inesperado (TATIT, 2010, p. 53-54).

O narrador de Nava busca esse entendimento posterior às rememorações, atribuindo seus rompantes ao mundo interior do próprio sujeito que se recorda:

É impossível colocar em série exata os fatos da minha infância porque há aqueles que já acontecem permanentes, que vêm para ficar e doer, que nunca mais são esquecidos, que são sempre trazidos tempo afora como se fossem dagora. É a carga. Há outros, miúdos fatos, incolores e quase sem som - que mal se deram, a memória os atira nos abismos do esquecimento. Mesmo próximos eles viram logo passado remoto. Surgem às vezes, na lembrança, como se fossem uma incongruência. Só aparentemente sem razão, porque não há associação de idéias que seja ilógica. O que assim parece, em verdade, liga-se e harmoniza-se no subconsciente pelas raízes subterrâneas - raízes lógicas! - de que emergem os pequenos caules isolados - aparentemente ilógicos ! só aparentemente! - às vezes chegados à memória, vindos do esquecimento que é outra função ativa dessa mesma memória. Sobem como pés de tiririca, emergem como Açores e Madeiras, ilhas perdidas na superfície oceânica, entretanto pertencentes a um sistema entrosado de montanhas subatlânticas. Assim a anarquia infantil do Tempo e do Espaço me impedem de contar Juiz de Fora em ordem certa, capítulo um, capítulo dois, capítulo três. São mil capítulos e inumeráveis entretanto capítulo único (BO, p. 222-223).

Retomamos, mais uma vez, o texto de Greimas acerca da estesia. Numa breve passagem, o semioticista já aponta para a interpretação que sucede aos momentos de rememoração, encontrando no próprio cotidiano seu deflagrador:

Cognitivamente inapreensível, esta fratura na vida é, depois, suscetível de todas as interpretações: crê-se reencontrar aí a insuspeitada espera que a precedeu, crê-se aí reconhecer a madeleine que remete às 
imemoráveis nascentes do ser; ela faz nascer a esperança de uma vida verdadeira, de uma fusão total do sujeito e do objeto. Ao mesmo tempo que o sabor de eternidade, ela deixa o ressaibo da imperfeição (GREIMAS, 2002, p. 70).

Em Nava, as figuras que concretizam o antissujeito são o tempo e a morte. A ação de ambos opõe-se à da memória. Em Baú de ossos, o narrador conta que, quando menino, não conseguia reconhecer sua tia velha e enrugada como a jovem do retrato: "Eu não suspeitara ainda da existência do Tempo e de sua atividade paciente, companheira da Doença paciente e da Morte paciente." (BO, p. 111). A memória faz reencarnar "tudo, tudo, todos, todos" num presente repentino (BO, p. 290), enquanto o "Tempo" e a "Morte": "reduzem tudo ao nada de tudo" (BO, p. 91). Eles criam a cisão entre o velho que recorda o passado e a criança, o adolescente ou o jovem que foi, entre o mundo dos vivos e o dos mortos, entre as cidades modernizadas e impessoais e as pretéritas, carregadas de sentido, enfim, eles criam a distância entre 0 sujeito e os valores desejados. Além disso, não se pode deixar de lado que o narrador das Memórias possui como um de seus papéis temáticos o de médico, combatente da morte e das doenças:

Assim, as Memórias não se compõem de um discurso puramente narrativo, mas também de um verdadeiro diálogo com o passado, com o que está morto e vivo, e no mais geral, com a própria idéia de morrer. Elas encenam o drama de um homem que vai arrastando consigo seus mortos e as muitas faces de si mesmo no decorrer do tempo, à medida que caminha para o palco presente, onde sua principal antagonista é de fato a Morte (ARRIGUCCI JR., 1987, p. 88).

Ao examinar seu corpo numa noite de insônia, reconhece as marcas da velhice, prenúncio da morte. Especialmente para o médico o corpo é texto onde se leem as impressões deixadas pelo tempo:

[...] aquele pedaço de corpo idoso era meu mesmo - meu pé velho. Triste, triste estendo as pernas, emparelho os dois pés, inspeciono-os agora, como médico. A pele desvivida, a turgência feia, a macilência de mau presságio, o desenho chinês das veiazinhas varicosas e eu baixo-os para não sofrer a tentação de ler em mim, como faço nos outros - os termos que me permitem o cálculo do seu restante (GT, p. 44). 
A perda das formas ("turgência feia", "macilência"), das cores ("pele desvivida"), da energia que esteve ali aproximam-no de uma não-vida. Com absoluta lucidez, ele analisa seu corpo, tratando-o como objeto destacado de si, observável à distância. Cada pequeno traço da velhice é examinado em uma lente de aumento da qual não escapa nenhum detalhe. $O$ enunciatário pode então construir para si uma imagem bastante nítida do corpo em exame, compartilhando o sentimento de emergência do fim. Algumas páginas adiante, o narrador descreve-se frente ao espelho do banheiro, mas ele não se vê na massa erodida. $O$ corpo decadente constitui um outro que o aparta de si, daquele que foi e que reconhece como seu verdadeiro eu.

Dolorosamente encaro o velho que tomou conta de mim e vejo que ele foi configurado à custa de uma espécie de desbarrancamento, avalanche, desmonte - queda dos traços e das partes moles deslizando sobre o esqueleto permanente (GT, p. 52).

Um bom número de páginas da primeira parte de Galo-das-trevas é dedicado ao relato dos percursos sentimentais de Nava no Rio de Janeiro, relato que vem sempre acompanhado pela avaliação disfórica do narrador: a cidade já não é mais a mesma. O curso das transformações do Rio, mesmo quando rumo a um "embelezamento", como afirma o narrador ironicamente, é visto como queda, decadência. Logo, o Rio contemporâneo ao narrador é, antes de mais nada, falta daquilo que foi no passado. Ele não encontra mais os lugares que fizeram parte de sua vida, não se reconhece mais nos espaços. Pode-se dizer que a cidade se mostra como extensão do corpo: ela também carrega traços que apontam para o aspecto terminativo, participando dum percurso decadente, além disso, tornou-se coisa estranha ao narrador, separando-se dele. A cisão entre sujeito e mundo é vivida no presente pelo narrador em seu grau máximo, pois ele está disjunto não apenas da cidade, mas até mesmo de seu próprio corpo.

Depois Itapiru leva à Rua da Estrela, Largo do Rio Comprido com as opções: Aristides Lobo da infância ou Bispo com Barão de Itapagipe e Delgado de Carvalho da adolescência - dois caminhos que 
proclamam a República na Rua Haddock Lobo. Todo esse Rio está morrendo... (GT, p. 8)

À medida que as obras do Metrô e a insensibilidade dos procônsules nossos governantes vão demolindo de preferência o que há de sentimental, histórico e humano no Rio de Janeiro, multiplico meus passeios nas ruas malferidas - como quem se despede (GT, p. 9).

O tempo e a morte, figurativizações do antissujeito na obra de Nava, no nível discursivo são construídos espacialmente no eixo vertical que vai de cima para baixo: causam "desbarrancamento, avalanche, desmonte - queda" ou ainda "Erosão", desmanche ("A pele frontal caiu sobre os olhos [...]"), demolições (GT, p. 53 e 9). Contra os responsáveis pelo desaparecimento de um mundo passado, insurge-se a memória. Funcionando num eixo espacial contrário, de baixo para cima, ela faz emergir das profundezas daquele que se recorda o que havia desaparecido.

O tempo e a morte inserem o sujeito numa temporalidade cronológica, linear, afastando-o do passado e ainda transformando aquilo que é presente em passado: funcionam no eixo temporal presente $\rightarrow$ passado e no eixo espacial alto $\rightarrow$ baixo. Já a memória - entendida como a genealogia, a memória voluntária ou involuntária, as fotografias, as cantigas que ficaram, os objetos pessoais, as casas que ainda restam - atua de maneira contrária, trazendo para o presente os valores almejados pelo sujeito e fazendo presente a ausência. Ela funciona no eixo temporal passado $\rightarrow$ presente e no eixo espacial baixo $\rightarrow$ alto. O efeito máximo de suspensão da passagem cronológica do tempo ocorre quando a rememoração vem tomar o presente como acontecimento.

Além disso, a memória permite saltos no tempo, pois aproxima momentos distantes, sobrepõe imagens de épocas afastadas. O esquecimento, figura que aparece inúmeras vezes na obra de Nava, pode dificultar a rememoração, como vemos no trecho em que o narrador mostra que o esquecimento torna os fatos do passado ("cometas") distantes, ou seja, ele provoca a saída das grandezas do campo de presença: "Outros, cometas, passam roçando e queimando; depois somem em trajetórias mergulhadas nas distâncias espaciais do esquecimento" (BO, p. 233). Entretanto, como a outra 
face da lembrança na constituição da memória, ele traz a supressão de intervalos, tornando possível fugir às coerções de uma temporalidade cronológica, linear e à organização sintagmática do espaço, já que faz o menino passar de um dia a outro e de um lugar a outro, sem levar em conta o que transcorreu entre eles:

Não é bem como eu disse antes, que anoitecia aqui, para acordar ali. A memória é que suprimia intervalos e permitia que eu passasse sem interrupção, da noite da Rua Direita aos terreiros ensolarados de secar café, em Santa Clara; da primavera da chácara do seu Carneiro ao verão do Rio Comprido e aos frios do Paraibuna (BO, p. 227).

Vemos, com isso, os papéis desempenhados na obra de Nava pelo tempo, pela morte, pelo esquecimento, pela lembrança e pela memória.

\subsubsection{Sobre a saudade e o ressentimento}

Dois efeitos patêmicos, duas posturas distintas em relação ao passado vão marcar o narrador das Memórias: a saudade e o ressentimento. Como mostra o antropólogo francês Marc Augé (1998, p. 19), o perdão, a indiferença ou a negligência estariam ligados ao esquecimento; já o remorso, a obsessão e o rancor, à lembrança. São todas "doenças" da memória, às quais vêm somarse a saudade e o ressentimento. No caso de Nava, observa-se a tendência às paixões mais relacionadas à lembrança, e não tanto ao esquecimento.

Embora o passado constitua-se como uma época melhor nas Memórias, isso não quer dizer que não sejam rememorados momentos difíceis e dolorosos, como o período em que, após a morte do marido, Dona Diva vai viver com sua mãe, a avó de Pedro Nava. A experiência na casa de Inhá Luísa, retratada como uma figura cruel, conservadora e que governa com mão de ferro o seu sobrado, é relatada em Balão cativo. Em Galo-das-trevas, o narrador também mostra a dificuldade enfrentada por Egon ao voltar à sua cidade natal, "Desterro". Mal recebido pelos parentes e sem conseguir grande inserção profissional e até mesmo social, o jovem médico retorna para Belo Horizonte.

No entanto, esses momentos mais sofridos não impedem o narrador de reconhecer no passado os valores desejáveis, enquanto o presente é marcado 
pela falta desses mesmos valores. Como mostra Aguiar (1998, p. 151-152), as Memórias trazem a imagem de um homem que viveu nas três primeiras décadas do século XX, um homem da Primeira República, que viu na casa de sua avó a manutenção ilegal do trabalho escravo, garantida pelos privilégios de classe.

Ao tratar das saudades do narrador nas Memórias, o crítico chama a atenção para o fato de que, ao longo dos seis volumes, é possível notar como os privilégios de classe sempre abriram portas para o narrador. Este faz críticas aos desmandos dos poderosos, mas não se reconhece como parte do sistema de troca de favores. Ele separa de maneira bastante maniqueísta a família de seu pai e a de sua mãe, elogiando muito o lado paterno formado por profissionais liberais e, principalmente, funcionários públicos intelectualizados. Ataca a parte materna, à qual pertence a tataravó que se interessava pela genealogia por orgulho e que tem entre seus antepassados grandes proprietários de terras de Minas. Chama esses parentes de "feudais". Aguiar (1998), no entanto, mostra que uma boa parte do comportamento desse lado da família é atribuído pelo narrador à natureza dos Pinto Coelho da Cunha, e não a aspectos sociais que dizem respeito à própria formação da sociedade brasileira.

Mesma postura pode ser identificada com relação às críticas dirigidas àqueles que não o ajudaram, ou seja, que não o "apadrinharam" como ele acreditava merecer:

Os favores, por exemplo, que motorizam inúmeras relações na obra nunca são problema, desde que os pedidos sejam atendidos. Quando isso não ocorre, a ira se volta contra quem não os atendeu, descartando-se a possibilidade de questionar um mecanismo que pressupunha, conforme o caso, que o pedinte desse com a cara na porta (AGUIAR, 1998, p. 155).

A saudade do narrador dirige-se, então, a um período em que sua família possuía maior prestígio e a escritura das Memórias relaciona-se ao que Arrigucci chama de "certa tendência à aceitação complacente dos traços de classe" e "gozo inconsciente de favores herdados da sociedade patriarcal" (1987, p. 91). Justifica-se assim o interesse pela genealogia, que ocupa boa parte da obra. Destaca-se com relação a isso, o livro Baú de ossos, que tem a 
vida dos antepassados do narrador como assunto de praticamente três dos quatro capítulos. Há vaidade no reconhecimento por parte do narrador de seu pertencimento a um grupo familiar. É revelador desse sentimento o uso do recurso da embreagem. O narrador emprega, às vezes, o presente no lugar do pretérito perfeito 2 , quando fornece a biografia de parentes, criando o efeito de que grandes acontecimentos históricos estão sendo narrados. O discurso torna-se grandiloquente.

Em 1900 meu pai cursa o quinto ano; está, a 30 de maio, no grupo que se acotovela na Casa da Saúde e é dos que ajudam a levar ChapotPrevost em triunfo depois da operação de Maria-Rosalina; freqüenta as aulas de José Benício de Abreu na $2^{\mathrm{a}}$ Cadeira de Clínica Médica; as de Henrique Ladislau de Sousa Lopes na Terapêutica; e quase morre às mãos de um galego à praia de Santa Luzia, nas portas da Santa Casa de Misericórdia (BO, p. 207).

O interesse pela genealogia também tem outros motivos, como o desejo de fazer o passado permanecer ${ }^{25}$. Além disso, ao recuperar a história, a fisionomia, os hábitos de seus antepassados, o narrador procura reconhecer-se num processo de autoconhecimento. É possível identificar aí uma concepção biológica da formação da identidade, que se adapta bem ao papel temático do médico, uma vez que as características que dizem respeito à psicologia e ao comportamento são tratadas de forma bastante semelhante aos aspectos físicos:

Esse riso, esse jeitão, esse cacoete, esse timbre de voz, esse olhar, esse choro, essa asma, essa urticária, esse artritismo, esse estupor, essa uremia - são nossos e eternos, são deles e eternos. (BO, p. 175-176).

É contra aqueles que o narrador identifica como inimigos que sua raiva é investida. As Memórias nesse sentido são ocasião para vingar-se. Em trecho já mencionado, Egon sugere que Nava use a escrita como arma contra os que Ihe fizeram mal (GT, p. 98). Especialmente na primeira parte

\footnotetext{
25 "[...] ele surge ali como o narrador das lembranças de família, velho guardião e transmissor do legado cultural do passado, formador da tradição em cadeia através do tempo, portador da experiência viva das gerações pretéritas" (ARRIGUCCI JR., 1987, p. 101).
} 
de Galo-das-trevas, o narrador apresenta o médico como um herói que não recebe a sanção merecida ${ }^{26}$ :

Duro é o estudo médico. Duríssima a vida do médico. Salvo uma ou outra exceção, os colegas são geralmente ferros de ponta e gume para nos trespassar e retalhar. O consolo e a compensação estarão? no exercício e no cliente. Ai! não, também. (GT, p. 93).

Notamos nesse trecho alguns fatores da configuração patêmica do ressentimento. Vamos abordar essa paixão, tendo como base principal o artigo de Fiorin (2007b) sobre o ressentimento na Universidade, além do estudo feito por Barros (1989-1990, p. 60-73) das paixões em geral e o de Greimas (1983) sobre a cólera especificamente, já que a diferença entre os dois estados passionais é principalmente aspectual. É preciso esclarecer que, para a semiótica, as configurações patêmicas constituem-se como fenômeno social e histórico:

[...] sobre um fundo geral de dispositivos modais mais ou menos complexos - 'atitudes' ou 'estados' -, cada sociedade traça os conteúdos de sua configuração patêmica particular que, interpretada como uma grade de leitura social conotativa, tem por tarefa, entre outras, facilitar a comunicação intersubjetiva e social (GREIMAS, 1983, p. 16; tradução nossa) ${ }^{27}$.

Greimas tem como ponto inicial as definições de dicionário do lexema "cólera", pois considera que o dicionário está inserido no seio de uma cultura determinada como qualquer outra obra e que já traz em suas definições uma primeira expansão da estrutura narrativa e discursiva da configuração patêmica. A primeira definição do Houaiss (2009) para "cólera" é "sentimento de violenta oposição contra o que molesta ou prejudica; ira". Apenas daí, depreende-se que um sujeito se sente prejudicado, acredita que recebeu alguma forma de ofensa, o que lhe causa um sentimento desconfortável, do qual decorre a "violenta oposição".

O exame das modalidades deve levar em conta as relações entre sujeito e objeto e entre sujeitos somente, constituindo parte necessária para a

\footnotetext{
${ }^{26}$ O narrador faz a distinção entre os "bons" médicos, os "brancos", e os que vê como "maus" médicos, os "marrons".

27 '[....] sur le fond général de dispositifs modaux plus ou moins complexes - 'attitudes' ou 'états' -, chaque société trace les contenus de sa configuration pathémique particulière qui, interprétée comme une grille de lecture sociale connotative, a pour tache, entre autres, de faciliter la communication intersubjective et sociale".
} 
compreensão das paixões, entendidas como "efeitos de sentido de qualificações modais que modificam o sujeito" (BARROS, 2002, p. 61) ${ }^{28}$. Assim, o estudo das paixões é feito a partir da análise da sintaxe modal, mas também de outras componentes, como indica Fiorin (2007a, p. 5-6): as paixões definem-se pelo tipo de objeto, pela ausência ou presença desse objeto, pela temporalidade, pela aspectualização e pela modulação tensiva. Elas são, por fim, moralizadas, ou seja, recebem uma avaliação social. O ressentido, por exemplo, é avaliado de forma negativa pela sociedade contemporânea.

Fiorin (2007b) mostra que o ressentimento nasce, narrativamente, de uma espera fiduciária frustrada. Um sujeito acredita que o outro deve fazer algo que ele quer, a partir de um simulacro criado desse outro. No caso de Nava, o ator do narrado esperava reconhecimento, prestígio e ainda certos benefícios. Na primeira vez em que vai à reunião da "Sociedade de Medicina e Cirurgia do Desterro", Egon decepciona-se, pois cria que o fato de ser filho do farmacêutico João Elisiário Pinto Coelho da Cunha Ihe garantiria aceitação imediata:

Egon tinha pedido ao Dimas para dizer o nome de seu pai quando o apresentasse. Todos aqueles médicos tinham sido seus amigos e ele esperava que o patronímico lhe fosse um abre-te-sésamo. Foi sua primeira decepção (GT, p. 212).

Isso não ocorrendo, o sujeito, além de sentir-se insatisfeito, por não entrar em conjunção com o objeto esperado, decepciona-se com o outro, no caso o conjunto de médicos que não lhe dão o reconhecimento "devido", e ainda consigo mesmo, por ter depositado suas crenças no sujeito errado: "[...] é preciso notar que ele [o ressentimento] na verdade não é uma paixão resultante da insatisfação, isto é, da carência do objeto, mas da decepção, ou seja, da falta fiduciária" (FIORIN, 2007b, p. 16). É o narrador que sofre das consequências das injúrias que acredita terem sido cometidas contra 0 protagonista no passado. A cada vez que relata os episódios que lhe

\footnotetext{
28 As modalidades, como entendidas na semiótica, resultam da conversão da categoria tímico-fórica fundamental e determinam, no nível narrativo, a relação entre sujeitos e objetos, entre sujeitos e suas ações e ainda entre dois sujeitos. As modalidades (querer, dever, poder, crer e saber) determinam o ser e o fazer (também modalidades). Há as modalidades virtualizantes (querer e dever), que instauram o sujeito, as atualizantes (poder e saber), que o qualificam para ação, e as realizantes (fazer) (BARROS, 2002, p. 53).
} 
trouxeram desgosto, pode ridicularizar aquele que o perturbou. Temos assim um estado passional iterativo.

O ressentido procura reparar no presente as faltas vividas. No entanto, ele é o "vingativo que recalca seu desejo de vingança" (FIORIN, 2007b, p. 16), sua cólera contida manifesta-se pelo humor amargo, pelas queixas e acusações. Greimas (1983), em seu estudo sobre a cólera, apresenta a vingança como uma ação que possibilitaria um reequilíbrio dos sofrimentos entre sujeitos antagonistas. Assim, o sujeito que acredita ter sofrido uma ofensa, ao fazer o antissujeito sofrer, experimenta o sentimento de prazer, obtendo a satisfação. Entretanto, o ressentido só consegue alcançar, como mostra Fiorin (2007b, p. 16), "uma vingança simbólica", colocando-se sempre num lugar de superioridade moral. É o que encontramos em Nava, especialmente quando as Memórias avançam:

O exame de consciência absolve-me completamente. Para fazer andar a Arte, ainda que só a linha que cada um tem de procurar, em direção do progresso que significa vida, garantia e bem-estar do semelhante, fiz o possível. [...] E vinte oito anos, cada semana uma noite de minha casa aberta para estudo e redação dos trabalhos em que permitia a co-assinatura daqueles que tinham a obrigação de fornecer-me os dados para essas monografias (o que os chefes agradecem com notas de rodapé). Eu redigia à máquina horas e horas e como palerma deixava ao lado do meu aparecerem os nomes dos que vinham cochilar vendo-me labutar para eles. Minto um olho era esperto e sempre faiscava. O daquele onde eu pensava ver luz simulando afeto filial mas onde só cintilava a cobiça do herdeiro sôfrego que usaria moralmente seu pó de sucessão e que depois de bajulador nauseante e felão, foi moralmente assassino e parricida (GT, p. 91).

Apesar do amargor com que o narrador ressentido reveste o seu presente, o sentimento que parece dominar as Memórias é a saudade: "Regido pelo testemunho pessoal, o gênero memorialístico não poderia existir se não fosse animado pelo sentimento, maior ou menor, para bem ou para mal, de nostalgia do passado vivido" (AGUIAR, 1998, p. 153). As interjeições seguidas de exclamação e as reticências recuperam na textualização o suspiro dado pelos saudosistas: "Ah! nesse tempo a madrugada da Glória era amena, sem assaltos..." (GT, p. 13). A grande 
recorrência do pretérito imperfeito, assim como das embreagens que presentificam o passado expressam o desejo de retorno.

A saudade tem origem, como mostra Greimas (1986) a respeito da nostalgia, numa comparação feita entre o passado e o presente. O narrador, ao relembrar as épocas pretéritas, mostra-se como alguém que crê que nesse outro tempo vivia um estado de conjunção com o objeto valor, enquanto no presente se encontra em disjunção. Comparando os dois períodos, ele constata a perda, a inadequação entre dois programas narrativos, um captado em seu hic et nunc e o outro convocado como simulacro narrativo, portador de uma euforia primeira. O sentimento de falta é instaurado, modalizando o sujeito com um querer. Embora não possamos tratar nostalgia como sinônimo de saudade, esse ponto as duas paixões possuem em comum. Uma das especificidades da saudade com relação a outras paixões da falta é que, quando o sujeito é tomado por tal estado passional, seu querer volta-se para valores inseridos em objetos com os quais acredita que já esteve conjunto, mas que perdeu.

Lidar com a sensação da falta parece ser o destino das Memórias; elas historiam ausências; afinal, são uma crônica de saudades. A cada passo devem enfrentar o poder da morte: o fosso aberto pelo tempo e pelo esquecimento, contraparte da própria memória (ARRIGUCCI JR., 1987, p. 87).

Na saudade, há o sentimento de melancolia, que tem como um de seus sentidos "estado afetivo caracterizado por profunda tristeza e desencanto geral" (HOUAISS, 2009), causado por essa incompletude ou falta: "Do ponto de vista semiótico,a reminiscência define um modo potencial que nasce do estado de falta nostálgica, a nostalgia sendo uma espera retrospectiva" (HAJJI-LAHRIMI, 1999, p. 76; tradução nossa) ${ }^{29}$. Narrar as memórias acaba sendo uma tentativa de reparar essa falta no presente, pois possibilita recriar o passado perdido, recuperando os valores almejados ${ }^{30}$.

29 "Du point de vue sémiotique, la réminiscence définit un mode potentiel qui prend source dans
l'état de manque nostalgique, la nostalgie étant un attente rétrospective".
30 Conforme mostra Savietto a respeito da citação incorporada por Nava dos versos de
François Villon (“Mais où sont les neiges d'antan?"): "Cumpre ratificar, conforme vimos
demonstrando até agora, que não é apenas a consciência da morte que mobiliza a pergunta
'ubi sunt' na obra de Pedro Nava; a saudade também o faz pois, ao indagar pelas coisas de 
No entanto, embora a reminiscência possa refazer a conjunção com os valores investidos no passado, reforça a certeza da irreversibilidade do tempo e da morte. Afinal, a imagem que vem à tona é uma presença da ausência:

Somos conduzidos pela preferência do espírito que é fuga, distração, descanso lúdico... Ave solta... Sua alteração, como que sua doença: o martelamento obsessivo que sucede no remorso, na saudade dos mortos, na dor-de-corno - em que tudo é pretexto de volta à imagem iterativa, dolorosa e adesiva, que nos tem - ai! Na gosma do seu círculo concêntrico. Pássaro no visgo... (BO, p. 292).

A cada vez que a lembrança ocorre e satisfaz apenas por um instante o desejo do sujeito, é confirmada a impossibilidade de manutenção da conjunção. Se os momentos de rememoração se apresentam nessa obra como experiências estésicas, em que o sujeito vive a fusão com o objeto, ou seja, o próprio passado lembrado, a saída do objeto do campo de presença deixa então o sentimento de falta que alimenta o desejo de uma nova conjunção. Mesmo experiências do passado que não possuíam tanta importância no momento da rememoração ganham novos sentidos, pois trazem a possibilidade de interromper o fluxo do tempo e de viver o sentimento de completude, de eternidade. O narrador diz que a evocação pode transformar algo banal numa vivência poética. Também apresenta a memória como experiência de eternidade:

A memória dos que envelhecem (e que transmitem aos filhos, aos sobrinhos, aos netos, a lembrança dos pequenos fatos que tecem a vida de cada indivíduo e do grupo com que ele estabelece contatos, correlações, aproximações, antagonismos, afeições, repulsas e ódios) é o elemento básico na construção da tradição familiar. Esse folclore jorra e vai vivendo do contato do moço com o velho - porque só este sabe que existiu em determinada ocasião o indivíduo cujo conhecimento pessoal não valia de nada, mas cuja evocação é uma verdadeira oportunidade poética $(\mathrm{BO}$, p. 9).

outrora, o narrador acaba por reacendê-las em sua memória o que não deixa de ser um meio de realizar a intenção maior de sua escrita: a de preservar sob todas as formas as imagens caras dos momentos passados" (2002, p. 173). 
Cada um guarda a paisagem de um ano, de um mês, uma semana, um dia, uma hora! - pedaço de espaço em que se comprimiu o Tempo - de que a memória vai construir sua eternidade (BO, p.193).

A saudade do passado confunde-se nessa obra à saudade da própria lembrança, já que em certas passagens não é possível distinguir se a rememoração é euforizada por recuperar valores do passado ou se é a memória que atribui valor ao passado. É o que fica sugerido quando o narrador fala do indivíduo "cujo conhecimento pessoal não valia de nada, mas cuja evocação é uma verdadeira oportunidade poética". Assim, ao longo dos seis volumes e, por que não, da vida, uma sequência de imagens transparentes vai sobrepondo-se ao passado. Nessa iteratividade da memória, ocorre o adensamento da intensidade da relação estabelecida entre sujeito e objeto, um adensamento dessa imagem e também da falta que ela carrega. A saudade funciona na obra num crescendo.

\subsection{Graciliano Ramos}

\subsubsection{Infância: memória e fragmentação}

Se em muitas obras autobiográficas a lembrança é desejada, por estabelecer certa continuidade entre o presente e o passado, em Infância (IN) ela é acusada de trazer de volta sensações dolorosas, já que o passado é construído como objeto que carrega valores disfóricos (opressão, tristeza, solidão, tédio, etc.).

A memória é veículo de sensações antigas que ganham materialidade ao tornarem-se imagem e, assim, lembrança. São sensações quase sempre negativas, tanto para a criança que se recorda de momentos anteriores - no passado narrado - quanto para o narrador adulto que se recorda da infância no presente da narração. No menino elas provocam com frequência o medo ou ainda o pavor, sua forma mais intensa:

Mas, arengando com Joaquim, na areia do beco, ou admirando o rostinho de anjo de Teresa, assaltava-me às vezes um desassossego, 
aterrorizava-me a lembrança do exercício penoso. Vozes impacientes subiam, transformavam-se em gritos, furavam-me os ouvidos; as minhas mãos suadas se encolhiam, experimentando nas palmas o rigor das pancadas; uma corda me apertava a garganta, suprimia a fala; e as duas consoantes inimigas dançavam: d, t. Esforçava-me por esquecêlas revolvendo a terra, construindo montes, abrindo rios e açudes (IN, p. 115-116).

Quando busca alguma fuga por meio da fantasia própria das brincadeiras, a memória traz de volta sensações deixadas em estado de latência, ou seja, potencializadas, que invadem seus ouvidos, sufocam sua garganta. $O$ excesso relacionado à audição e a falta relacionada à fala (ele escuta demais e não pode falar) apontam igualmente para a impossibilidade de comunicação e ainda para a impossibilidade de ajustamento da criança ao mundo: não há adequação. O mundo é sempre avaliado como insuficiente (no caso do sentimento de tédio, gerado pelas atividades repetitivas) ou como excessivo (caso ilustrado aqui). É o que se verifica ainda quando a criança amedrontada vive a sensação de encolhimento à medida que o tamanho do pai aumenta.

A impossibilidade de agir (não-poder-fazer), ou a paralisia, é figurativizada pelo fechamento dentro de si ("mãos suadas se encolhiam"), pela ausência de comunicação verbal ("suprimia a fala"). O suor, os tremores no corpo (que aparecem em outras passagens) são alguns dos traços somáticos que marcam o sentimento de medo, revelando, por meio das reações corporais, os estados de alma do menino. Essa é a única forma de comunicação que lhe é permitida. O corpo se torna uma prisão, figura repetida no texto, na qual o menino se fecha, sem qualquer possibilidade de troca com o mundo exterior. As imagens sobrevêm ao presente da criança, como um acontecimento, retirando-lhe a possibilidade de compreender ou mesmo de tomar a palavra.

Se no menino a lembrança provocava principalmente o medo, no caso do narrador adulto, ela desperta outra paixão: o rancor - cólera durativa e contida, causada pela sensação de injustiça vinda das muitas quebras de contrato vividas pelo menino na relação com seus familiares, especialmente 
com o pai ${ }^{31}$. É preciso dizer que a figura do pai, um pequeno proprietário de terras que faliu, recobre o papel do grande destinador nessa obra. Ele estabelece o valor dos valores, as regras, a ordem, e tudo por meio da violência. A revolta do narrador dirige-se, então, a todo um sistema de valores existente no Brasil.

Esse aspecto parece diferenciar o ressentimento em Nava do rancor em Graciliano. O ressentido desenvolve o desejo de vingança, ainda que recalcado. Seu amargor é direcionado para o antissujeito, e não para o destinador. Ele não recusa o sistema de valores de seu ofensor. É isso que vemos na obra de Pedro Nava, uma vez que o narrador, identificado ao enunciador, não se revolta contra a lógica da troca de favores, mas quer prejudicar aqueles que não o ajudaram. Em Infância, percebe-se no narrador, identificado ao enunciador, a revolta, ou seja, a recusa do destinador (o pai ou a sociedade da qual ele fazia parte) e a busca de uma nova axiologia. A intensidade do sentimento que domina o sujeito também diferencia os dois efeitos patêmicos. O ressentido experimenta uma raiva menos intensa; enquanto o rancoroso vive algumas "explosões" de ódio.

O rancor é deflagrado por uma sensação vivida no presente que, por uma relação de similitude, faz emergir antigas sensações sempre desagradáveis e, assim, o passado doloroso.

Onde estava o cinturão? Hoje não posso ouvir uma pessoa falar alto. $O$ coração bate-me forte, desanima, como se fosse parar, a voz emperra, a vista escurece, uma cólera doida agita coisas adormecidas cá dentro. A horrível sensação de que me furam os tímpanos com pontas de ferro. Onde estava o cinturão? A pergunta repisada ficou-me na lembrança: parece que foi pregada a martelo (IN, p. 35).

A lembrança instaura a continuidade do passado no presente, enquanto o esquecimento produz a fratura. Quando o menino descobre que Fernando, o homem que considerava tão mau, preocupava-se com as crianças, passa a duvidar das afirmações lidas em uma antiga enciclopédia que apontava Nero como o pior dos seres. O esquecimento é então nessa obra aquilo que rompe,

${ }^{31}$ No capítulo "Um cinturão" (IN, p. 33-37), é possível notar com clareza a diferença entre o discurso passional - nesse caso, identificamos um narrador tomado pelo rancor - e o discurso sobre uma paixão (GREIMAS, 1983, p. 246), ou seja, que trata da paixão no nível do enunciado - estamos falando do medo sentido pelo menino. 
que instaura a descontinuidade. É eufórico, já que permite, com sua ação corrosiva, o distanciamento do narrador em relação ao passado.

Esqueci as torpezas cochichadas, condenei o dicionário vermelho que tinha bandeiras e retratos. Talvez Nero, o pior dos seres, envergasse os pregos que poderiam furar os pés das crianças (IN, p. 227).

O esquecimento também evidencia a falta de controle do sujeito recordador sobre sua memória. Por mais que ele se esforce, algumas lembranças permanecem ocultas. É o caso do sentido de uma das palavras que compunha uma história ouvida quando criança.

Esqueci o resto e não consigo lembrar por que razão tributo serviu para designar fogo (IN, p. 19).

Muitas vezes o narrador explicita sua ignorância sobre certos fatos e, principalmente, sobre a passagem de um lugar para o outro, criando uma descontinuidade espaçotemporal, característica da maneira lacunar como a memória é recriada.

Ignoro como chegamos à fazenda: as minhas recordações datam da hora em que entramos na sala (IN, p. 40).

Outras estações fugiram-me da memória (IN, p. 176).

Meu pai e minha mãe conservavam-se grandes, temerosos, incógnitos. Revejo pedaços deles, rugas, olhos raivosos, bocas irritadas e sem lábios, mãos grossas e calosas, finas e leves, transparentes. Ouço pancadas, tiros, pragas, tilintar de esporas, batecum de sapatões no tijolo gasto. Retalhos e sons dispersavam-se (IN, p. 14).

A primeira coisa que guardei na memória foi um vaso de louça vidrada, cheio de pitombas, escondido atrás de uma porta. Ignoro onde o vi, quando o vi, e se uma parte do caso remoto não desaguasse noutro posterior, julgá-lo-ia sonho. Talvez nem me recorde bem do vaso: é possível que a imagem, brilhante e esguia, permaneça por eu ter comunicado a pessoas que a confirmaram (IN, p. 9).

O fragmento é assim a forma encontrada para mostrar o modo de funcionamento da memória, sempre incompleta nessa obra. Apenas os 
momentos passados mais marcantes são trazidos ao texto, o que permite supor que a memória funcione em Infância por operações de triagem, selecionando do vivido as experiências mais intensas. A fragmentação já se deixa ver na maneira de organizar os capítulos, quase sempre curtos e concentrados em um acontecimento extremo, mostrando pedaços do passado. Mesmo a identidade da criança, no passado narrado, constitui-se por um processo de purificação e de diferenciação da família, logo, por operações de triagem.

É, no entanto, no relato dos momentos de maior violência e, assim, maior pavor da criança que o esquecimento parece agir com maior eficácia sobre a memória do narrador. A impossibilidade por parte do menino de tomar a palavra encontra equivalência na fragmentação do texto. $O$ narrador revela ter dificuldade para contar o que ocorreu e também para recordar certos acontecimentos vividos. É o caso do episódio em que relata a surra que tomou do pai porque este não conseguia encontrar o seu cinto. A sequência de orações justapostas e sem ligação, as frases nominais e os substantivos isolados nas frases são alguns dos elementos que revelam o esfacelamento da linguagem. As figuras apontam para as sensações corporais que dominam 0 menino. Além disso, a pergunta repetida pelo pai (“Onde estava o cinturão?”) e algumas reflexões do narrador interrompem a todo momento a continuidade narrativa da cena. Esses elementos contribuem para fragmentar ainda mais 0 texto, criando intervalos e descontinuidades textuais. Numa primeira leitura, o leitor sente certa dificuldade de entender exatamente o que se passa. Podemos, então, homologar, numa espécie de semissimbolismo, a fragmentação textual à fragmentação da memória.

Aperto na garganta, a casa a girar, o meu corpo a cair lento, voando, abelhas - e, nesse zunzum, a pergunta medonha. Náusea, sono. Onde estava o cinturão? Dormir muito, atrás dos caixões, livre do martírio (IN, p. 36).

A mão cabeluda prendeu-me, arrastou-me para o meio da sala, a folha de couro fustigou-me as costas. Uivos, alarido inútil, estertor (IN, p. 36). 
Assim, o texto de Infância se torna cada vez mais cheio de incompletudes, indicando que a experiência terrível não pode ser totalmente revivida pelo narrador na linguagem, mas apenas imaginada.

Não consigo reproduzir toda a cena. Juntando vagas lembranças dela a fatos que se deram depois, imagino os berros de meu pai, a zanga terrível, a minha tremura infeliz. Provavelmente fui sacudido (IN, p. 35).

Desse antigo verão que alterou a vida restam ligeiros traços apenas. $\mathrm{E}$ nem deles posso afirmar que efetivamente me recorde. O hábito me leva a criar um ambiente, imaginar fatos a que atribuo realidade. [...] $\mathrm{O}$ meu verão é incompleto. (IN, p. 27-28).

$\mathrm{Na}$ obra de Graciliano, encontramos com grande frequência 0 acontecimento negativo associado à recordação, algo menos comum nas Memórias de Nava. Em Nava, o narrador experimenta a sensação de prazer quando as lembranças o "capturam" de forma acelerada e repentina, mesmo que precise depois compreender o que ocorreu ${ }^{32}$. Já em Graciliano o narrador, ao ser "invadido" pelas recordações dos momentos de medo e sofrimento, é tomado pelo sentimento de raiva e pela sensação de dor: "sensação de que me furam os tímpanos com pontas de ferro" (IN, p. 35). Geralmente essas experiências são relatas por meio da fragmentação textual, conforme mostramos, como se o acontecimento indesejável não pudesse ser contado.

Entretanto, a negação da possibilidade de narrar revelada, no texto, pelas incompletudes e quebras na narrativa é justamente o que faz aparecer o passado terrível. Talvez um texto muito explicativo, em que todas as lacunas estivessem preenchidas, perdesse parte de sua intensidade. Ao esconder, 0 discurso mostra ou ainda esconde e mostra. Aquilo que estava esquecido força sua aparição no discurso e deixa-se perceber na fragmentação. Se o menino e

\footnotetext{
${ }^{32}$ Como explica Tatit: "[...] o acontecimento (bem-vindo ou indesejável) traz consigo um valor de precipitação que retira o sujeito de seu próprio fluxo constante de vida e o faz, a contragosto, saltar etapas. A perda de segmentos temporais subjetivos, cujo encadeamento garante a consciência do ser no mundo, produz nesse sujeito lacunas de identidade que precisam ser preenchidas. Não é por outra razão que o indivíduo surpreendido por algo se põe imediatamente a reconstruir a duração omitida na esperança de reassumir o controle do seu tempo interior, vale dizer, de sua própria identidade. 'Arrumar-se' para avaliar um acontecimento corresponde a desacelerar o que se apresentou de modo excessivamente veloz e transformar o sobrevir em devir' (2010, p. 81-82).
} 
o narrador tiveram a fala cortada, não é o caso do enunciador, que, de certa forma, "toma a palavra". A fragmentação é a lembrança que ficou do passado, de uma totalidade perdida, que se tornou primeiro memória, ou seja, foi potencializada, para por fim ser esquecida (virtualizada). Entretanto, é possível entrever essa totalidade como aquilo que falta ao fragmento. Logo, o fragmento a reconstrói, mas como falta.

A fragmentação também aponta para a construção pelo enunciador de uma nova totalidade (a obra literária). Os vazios desvelam a possibilidade do preenchimento e, assim, da escritura literária, enquanto completude a se fazer. Podemos pensar Infância como texto fragmentário que produz o efeito de presença atualizada e não realizada, como se no meio do caminho entre o que foi e o que será.

Nesse livro, não estão em evidência procedimentos que fortaleçam o efeito de realidade. Isso é confirmado, entre outros recursos, pelo fato de o nome "Ramos" aparecer uma única vez na obra e "Graciliano" nenhuma, diferentemente do que ocorre com "Pedro", "Pedrinho" ou "Nava" nos longos volumes das Memórias. Os tempos, espaços e atores são apresentados com menor precisão que em Nava: "Mergulhei numa comprida manhã de inverno. $\mathrm{O}$ açude apojado, a roça verde, amarela e vermelha, os caminhos estreitos mudados em riachos, ficaram-me na alma. Depois veio a seca” (IN, p. 22). Poucas alusões são feitas a sobrenomes, a nomes de cidades, ruas ou bairros e a datas ou acontecimentos históricos. Apenas aparece aquilo que fazia sentido para o garoto. Também não são muito mencionadas as fontes das histórias ou a existência de documentos que as comprovem. O narrador deseja mostrar o passado a partir do ponto de vista do menino que foi, sem extrapolar demais suas experiências. Incorpora das histórias contadas por outras pessoas apenas aquilo que já não pode mais separar de suas próprias lembranças:

Talvez nem me recorde bem do vaso: é possível que a imagem, brilhante e esguia, permaneça por eu ter comunicado a pessoas que a confirmaram. Assim, não conservo a lembrança de uma alfaia esquisita, mas a reprodução dela, corroborada por indivíduos que the fixaram o conteúdo e a forma (IN, p. 9). 
Todos esses recursos até poderiam produzir a ilusão do real, já que o relato abarca, essencialmente, aquilo que o narrador viveu quando era criança, contudo o passado é apresentado como parte da memória narrada.

Datam desse tempo as minhas mais antigas recordações do ambiente onde me desenvolvi como um pequeno animal. Até então algumas pessoas, ou fragmentos de pessoas, tinham-se manifestado, mas para bem dizer viviam fora do espaço. Começaram pouco a pouco a localizar-se, o que me transtornou. Apareceram lugares imprecisos, e entre eles não havia continuidade. Pontos nebulosos, ilhas esboçandose no universo vazio (IN, p. 12).

A preocupação maior não parece ser, então, a de criar o efeito de que aquele mundo apoia-se num referente externo, mas o de ser fiel ao modo de funcionamento da memória do narrador, cheia de lacunas e artifícios e, ainda, aos sentimentos e paixões vividos por um menino que cresceu em fazendas e vilarejos do sertão nordestino.

\section{CONSIDERAÇÕES FINAIS: A PROSA LITERÁRIA AUTOBIOGRÁFICA}

Em Nava, a reconstrução do passado na linguagem é feita de forma bastante icônica. As cidades, as ruas, as casas e edifícios, além de serem localizados quase sempre com grande precisão, em geral também passam pelo "pincel" do narrador, que recria para o leitor do todo ao detalhe. Praticamente todos os atores que fazem parte das Memórias possuem nome, sobrenome, profissão, endereço e, muitas vezes, até mesmo genealogia. Para muitos deles, o narrador cria um retrato minucioso. Ele também fornece todo tipo de informação sobre o biografado, inserindo-o em seu grupo de amigos, suas relações de trabalho, sua rotina:

O doutorando José Nava inaugura o século nesse estado. Tenho em mão o seu cartão de matrícula, assinado por Francisco de Castro. Meu Pai é o número 6 do 6 o ano. Além da farmácia, da Policlínica e da Santa Casa, ele arranja mais trabalho. É da diretoria do Grêmio dos Internos dos Hospitais do Rio de Janeiro e interno da Casa de Saúde Dr. Eiras, onde conquista a amizade de seu Diretor, o psiquiatra Carlos Eiras, inspirador e orientador de sua tese. Ali reside 
um ano e lá está de pé o chamado chalé, onde ele habitou, e vias, as árvores que o viram vivo. Seus mestres nesse ano seriam Rocha Faria, na Cadeira de Higiene; Nuno de Andrade, na $1^{\text {a }}$ de Clínica Médica; Feijó Júnior, na Obstetrícia; e Miguel Couto, que praticamente substituía, na Enfermaria e na Cadeira, o Castro tomado pela direção da Faculdade (BO, p. 208).

Quanto à localização temporal, encontramos nas Memórias uma enorme quantidade de datas precisas relacionadas à história, tanto do pequeno grupo familiar, como da cidade ou do país. Os fatos históricos, muitas vezes, servem de referência para os que interessam apenas ao clã familiar, como no trecho em que o narrador fala do avô materno: "Após a Abolição, a 18 de julho de 1888, ele recebeu o título de Visconde de Jaguaribe, com Grandeza" (BO, p.162).

Assim, são abundantes os topônimos e cronônimos, elementos que possuem a função de ancoragem. Sua presença visa, portanto, a "construir o simulacro de um referente externo e a produzir o efeito de sentido 'realidade'" (GREIMAS; COURTÉS, 2008, p. 30). Somam-se a esses índices espaçotemporais, os antropônimos, que, ao denominarem os atores por nomes próprios, singularizando-os, participam da figurativização e também contribuem para o efeito de realidade.

Tal efeito é fortalecido ainda pela identidade produzida entre enunciador, narrador e protagonista, o que dá sustentação à afirmação do narrador de que relata aquilo de que se lembra. $E$, sobre isso, ninguém pode saber mais do que ele. $O$ fato de o narrador ser a pessoa que vivenciou o que narra funciona como uma espécie de argumento de autoridade. Ele dá o seu testemunho. Para aquilo que não poderia ter vivenciado, como a juventude dos avós, fornece dados que, pelo grau de detalhamento, dão a impressão de exatitude. Além disso, referências a documentos são feitas para "comprovar" o que se conta: o narrador recorre a certidões, fotografias, livros de história, anotações dos parentes, etc. Do arquivo do tio Antônio Salles, o narrador extrai as "quadrinhas" sarcásticas a respeito do professor Nuno de Andrade. Os versos são incorporados a Baú de ossos, antecedidos pela nota: "Do arquivo de Antônio Salles, hoje em minhas mãos, tiro mais as seguintes quadrinhas" (BO, p. 214). O efeito resultante de todos esses procedimentos é 
que o passado aparece como objeto cuja existência independe daquele que o narra.

Entretanto, inúmeras outras artimanhas discursivas parecem relativizar o efeito de realidade. O narrador, muitas vezes, apresenta um saber maior do que o esperado de um narrador de autobiografia. Ele narra, com muitos detalhes, algumas experiências que não testemunhou. Em alguns momentos, chega até mesmo a descrever os estados passionais e os pensamentos de antepassados distantes, como um narrador onisciente. Vemos isso no trecho em que ele fala da terrível Dona Irifila, esposa de um dos irmãos de seu avô, "presença aberrante" (BO, p. 21) na família de sua avó paterna, que só contava com mulheres boas, laboriosas e submissas. Dona Irifila um dia prega uma peça no marido, servindo fezes ao Visconde de Ouro Preto: "Dona Irifila sorriu-se toda quando foi avisada e aninhou-se no enredo da tocaia" (BO, p. 21). A reação do marido foi o choro franco; a do visitante, abrir os braços para receber "o compadre chorando convulsivamente, tremendo da cabeça aos pés, lívido da dor esquisita que lhe atravessava o peito, o estômago e banhado dum suor de agonia..." (BO, p. 23).

Também enfraquecem o efeito de realidade algumas afirmações do narrador. Ele diz que não precisa reinventar certo sobrado, por tê-lo conhecido, o que faz o leitor supor que as outras casas pelas quais seus antepassados passaram sejam criações do narrador. Sobre o trajeto feito por seu avô para o trabalho, o narrador confessa: "Não é difícil imaginar como ele faria esse caminho se juntarmos à verdade o verossímil que não é senão um esqueleto de verdade encarnado pela poesia" (BO, p. 58). Afirma ainda que é preciso recompor o passado a partir do que restou nos vivos, invertendo a cronologia dos fatos, pois faz do presente a fonte do passado, algo próprio à memória.

A subversão da cronologia também aparece quando 0 narrador reconhece que, muitas vezes, o esquecimento deturpa as lembranças, misturando umas às outras, evita alguns fatos dolorosos e ainda confude sua ordenação, produzindo saltos. No entanto, esse saltos são mais da ordem do "dito" e não tanto do "dizer", já que, nessa obra, revela-se o desejo de preencher todas as lacunas que poderiam ter sido deixadas pelo esquecimento. Apesar disso, os avanços e os recuos na história não deixam 
de aparecer. As presentificações do passado também permitem fugir da passagem linear do tempo. Elas revelam ainda o sujeito por trás do discurso, oferecendo-o para o leitor como aquilo que é: construção. Destacamos uma passagem em que o narrador viaja até os tempos de juventude do avô, como se tivesse tomado parte nos banhos de mar.

Somos agora três adolescentes vivendo os banhos salinos que ouvi narrar a Ennes de Souza. Fugas ladeira abaixo até o vindouro de canoas de pesca, a praia idílica e pobre, as gaivotas e as tapenas, nuvens de borboletas caindo nas ondas como flores que despencam, $o$ mar todo crespo, espumoso e aderindo exatamente a cada saliência ou dobra do corpo, amargo ao gosto, ardendo nos olhos do mergulhador. Os peitorais novos em folha empurram-no de encontro ao horizonte (BO, p. 14).

O trecho apela para os sentidos. O narrador, identificado ao enunciador, coloca-se no meio do mar e descreve as sensações experimentadas: ele pode tocar a água ("mar crespo e espumoso"), sentir o seu sabor amargo e uma ardência nos olhos. A rememoração, se podemos chamar assim, textualiza-se por meio de uma enumeração de frases nominais. A imagem aparece, por meio desse procedimento, como que congelada no tempo, ocorrendo no agora da enunciação.

Logo, a memória do narrador é formada também pela dos outros. Conforme ele narra o passado, apropria-se dele. Tudo o que é relatado parece ter uma ligação direta com esse narrador (até a primeira parte de Galo-dastrevas), não só de uma forma implicativa - o passado aparecendo como "causa" do que o narrador é -, mas também por apresentar o mundo pretérito, inclusive anterior a seu nascimento, como algo gerado de sua própria memória e do qual seu corpo pode participar.

O vínculo afetivo não tem origem apenas no fato de o narrador lembrarse de sua presença no passado, retomando a maneira como percebia o tempo e o espaço, mas também na própria rememoração. Conforme já mostramos, ele afirma que visita com regularidade a Biblioteca Nacional para construir o seu conhecimento a respeito do Rio de Janeiro. Ao flanar pelas ruas do Rio, projeta cenas da história da cidade e da literatura: 
Mas aqui é a Igrejinha, adiante dela a Praça de Santa Edwiges que dá na Avenida Brasil. Sempre não. Só vejo o mar praia de São Cristóvão e a ponte donde Rocca e Carleto saíram no Fé-em-Deus levando o menino Fuoco para lá de todas as águas...(GT, p. 7).

O narrador afirma que isso o ajuda a "corrigir os homens sem imaginação", que enxergam apenas o que está diante dos olhos. Rememoração ou imaginação? Isso parece ter pouca importância, pois, em ambos os casos, reconhecemos a presentificação de algo que está ausente ${ }^{33}$. Hajji-Lahrimi (1999, p. 41) afirma que a espera do não ainda se opõe à nostalgia do já ido; enquanto o primeiro resolve-se na lembrança, o segundo toma forma na imaginação ${ }^{34}$. Apesar da oposição, lembrança e imaginação repousam sobre uma base comum, pois constituem um simulacro e ainda uma presentificação (HAJJI-LAHRIMI, 1999, p. 43). Em ambos os casos, observa-se a emergência de um então e de um lá no aqui e agora; se a lembrança traz para o presente um passado, a imaginação antecipa um futuro possível. O passado aparece então como objeto cuja existência está em relação de dependência com a maneira que o sujeito o percebe.

Podemos afirmar que o universo descrito de forma minuciosa, pautado pela exaustividade, é vivido pelo enunciador de forma intensa, numa relação conversa entre extensidade de informações, dados, fatos, e intensidade da assunção desse passado monumental pelo sujeito. A verdade deixa de passar pelo efeito de referência apenas, para constituir-se também como poesia. É o que vemos quando o narrador fala de seus passeios pelo Rio de Janeiro para fazer "um guia do velho Rio diluído, dispersado e oculto pelo Rio moderno" (GT, p. 23). A grande quantidade de informação manipula o leitor pelo impacto:

O 214 é um belo sobrado restaurado, imponente nos seus três pisos. O 228 outro, com cinco janelas em cima, entrada central embaixo, duas

\footnotetext{
${ }^{33}$ Ricoeur (2003, p. 16) afirma que três traços participam do processo de rememoração: presença, ausência, anterioridade. A anterioridade diz respeito à representação do passado, à distância temporal, marcada por certos tempos verbais. A presença é aquela de uma imagem que ocorre como traço, vestígio ou signo da coisa ausente. A ausência pode ser de uma ficção, de uma fantasia, de uma alucinação ou de uma coisa real, trazendo à tona a problemática da fronteira entre a memória e a imaginação, a lembrança e a ficção.

${ }^{34}$ A relação entre a espera e a recordação já havia sido observada por Greimas: "Para passar do figurado ao próprio, nossas nostalgias, observadas mais de perto, não são senão recordações de esperas abortadas. A montante e a jusante, o essencial de nosso imaginário aí se resume" (2002, p. 86).
} 
janelas de cada lado. A porta tem superiormente abertura vedada por serralheria dum luxo e duma invenção que fazem dela uma das mais lindas do Rio. Os intervalos e vazios de seu rendado metálico ventilam o vestíbulo do prédio que honra a ladeira por sua autenticidade respeitada. O 279, antigo 124, mostra grande portão da chácara que sobe morro acima. Do 311 ao 325 estão as casas, parece que da idade da igreja, onde já esteve o consistório da irmandade e que serviam para abrigo dos romeiros. O catálogo telefônico, no endereço dessas construções, mostra que elas estão ora ocupadas por particulares. Chega-se ao ponto mais importante do nosso bairro, que é a praça onde se levanta a igreja da Imperial Irmandade de Nossa Senhora da Glória. Aqui os passos que seguimos são os dos nossos Imperadores e daquela gente cuja lembrança faz a poesia dos dois reinados (GT, p. 22).

Essa maneira de organizar o discurso permite depreender o éthos do enunciador, a imagem dada por uma forma singular de dizer. O corpo do ator da enunciação, Pedro Nava, é desmedido. Em tudo o que apresenta, o enunciador se reconhece. As palavras do narrador reforçam nossas observações, tanto pelo uso da enumeração quanto pelo que é dito a respeito da casa:

Ah! Longe de mim maldizer a minha casa. Estou impregnado de suas paredes do seu ar do mesmo modo que ela o está de minha pessoa, dos desgastes do meu corpo cujos fragmentos ficam pulverizados nos revestimentos, no chão, no teto - cabelos caídos, esfoliações de pele, excretas pelo cano, ar expirado, palavras vivas um instante, gemidos murmúrios resmungos (GT, p. 25).

A voz comporta diversas tonalidades. Reconhecemos o tom saudoso, 0 sarcástico, o amargo, entre outros. O caráter é moralizante. As Memórias apresentam uma visão de mundo bastante maniqueísta. As ações são, muitas vezes, avaliadas a partir dos benefícios ou malefícios trazidos ao narrador ou ao protagonista.

Nesse ponto, retomamos a breve análise de Infância para chamar a atenção para o fato de que a extensidade de informações não é uma característica da autobiografia literária em prosa, mas da obra de Nava e talvez de algumas outras. No livro de Graciliano, as arestas não são aparadas. Apesar de ambas as obras parecerem caminhar para a construção de um 
passado como fruto da memória, Graciliano se mostra menos preso aos efeitos de referência.

A partir da segunda metade de Galo-das-trevas ocorre uma mudança. Conforme mostramos, a identidade fundadora dos gêneros autobiográficos torna-se algo ambíguo e surge um alter ego, construído como ser de papel. Para criar Egon, o narrador lança mão de recurso bastante usual na ficção, o encontro dos manuscritos, algo que vemos em Dom Quixote ou em O nome da Rosa. Tudo isso poderia apontar para uma estetização maior do passado, no sentido de que ele poderia se desprender completamente dos procedimentos que apontam para a criação do efeito referencial. Entretanto, não é o que pudemos verificar. O narrador se distancia da narração, por meio de tempos, de espaços e, na segunda parte desse quinto volume, também de pessoas, discursivizados no narrado a partir do sistema enuncivo. Esse recurso cria o efeito de objetividade e distanciamento, afastando o enunciador da matéria narrada e também o enunciatário. É preciso dizer que a aparição de Egon leva às últimas consequências a diferença já dada pelo sistema temporal entre o eu do narrado e o eu da narração, aumentando a cisão vivida pelo narrado1/enunciador e o mundo; ele não pode mais reviver o passado pela lembrança.

Outras estratégias linguísticas e discursivas poderiam ser empregadas para reverter isso, mas não é o que se manifesta. Comparando os momentos em que o passado ressurge em Baú de ossos e Galo-das-trevas, vemos que há uma queda no impacto sentido pelo leitor. Reproduzimos a seguir um pequeno trecho de Galo-das-trevas:

E ele marchava na claridade que despencava em catadupas do sol de assombro, retomava a impressão desértica que lhe sugeriam os baldios e os muros mortos daquela ponta de rua. Tinha a impressão desértica que lhe sugeriam os baldios e os muros mortos daquela ponta de rua. Tinha a impressão de estar num areal, numa estepe, num pampa infindável onde o dia jamais teria fim com aquele sol estacado ao gesto mágico dum Josué. O céu era outro descampado imenso, imóvel da parada do astro e da falta dos ventos - duro e mineral - calota de turquesa inexorável (GT, p. 322). 
Em Baú de ossos, nesses momentos, a enumeração, as frases nominais, a falta de conjunções, entre outros recursos, fazem com que o que é acontecimento para aquele que se lembra apareça como acontecimento para o sujeito da enunciação. No geral, não é o que ocorre em Galo-das-trevas. Na passagem mencionada, vemos que Egon recebe o passado como algo intenso, que abre uma clareira no cotidiano. Ele sente-se inclusive angustiado antes de pisar as ruas percorridas na infância, prenunciando a possível revivescência. Já para o sujeito da enunciação muito é explicado, as frases aparecem completas, bem encadeadas, a leitura é mais lenta. Há, portanto, de um livro para o outro uma perda na intensidade com relação à enunciação, enquanto a extensidade se mantém dilatada. 
CAPÍTULO 2

PoESIA: MEMÓRIA E PRESENÇA EM MANUEL BANDEIRA

Tout discours de "ma vie" est un discours sur la Mort.

Herman Parret

Le sublime du quotidien

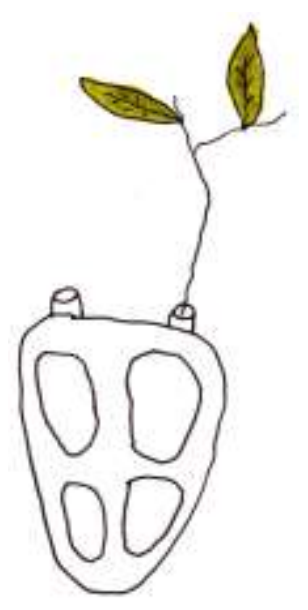


Em Bandeira, a tendência de olhar para a morte é tão grande quanto a de olhar para a própria vida. Não é por acaso que se dá a recorrência desses dois temas, em sua obra indissociáveis. $O$ autor produziu, além de diversos poemas e crônicas de caráter autobiográfico, também a obra em prosa Itinerário de Pasárgada (1984), em que vida e poesia se misturam na narrativa do passado.

Para este capítulo fizemos uma seleção de alguns poemas em que a memória e a autobiografia parecem constituir elementos centrais, uma vez que possuem como temática a recriação do passado por meio da escritura das memórias. Eles pertencem a fases diferentes do autor, o que para este trabalho representa um ganho, já que, além de observarmos características específicas de cada texto, também pretendemos depreender um modo próprio de fazer autobiografia na poesia, especialmente em Bandeira. Assim, escolhemos centrar nossa análise em "Evocação do Recife" e "Profundamente", que pertencem ao livro Libertinagem (publicado em 1930), "Infância", de Belo Belo (publicado em 1948, em Poesias completas), e "Recife", de Estrela da tarde (publicado em 1963).

Nesses quatro poemas encontramos algumas características próprias das obras autobiográficas, como será possível mostrar ao longo da análise, e em particular da autobiografia em Bandeira e na poesia. Apresentamos os poemas a seguir ${ }^{35}$ :

\section{PROFUNDAMENTE}

Quando ontem adormeci

Na noite de São João

Havia alegria e rumor

Estrondos de bombas luzes de Bengala

Vozes, cantigas e risos

Ao pé das fogueiras acesas.

No meio da noite despertei

Não ouvi mais vozes nem risos

Apenas balões

Passavam, errantes

35 Utilizamos para este trabalho a 25a edição do livro Estrela da vida inteira (1993), de Manuel Bandeira ("Profundamente", p. 139-140; "Evocação do Recife" p. 133-136; "Infância", p. 208209; "Recife", p. 249-250). 
Silenciosamente

Apenas de vez em quando

O ruído de um bonde

Cortava o silêncio

Como um túnel.

Onde estavam os que há pouco

Dançavam

Cantavam

E riam

Ao pé das fogueiras acesas?

- Estavam todos dormindo

Estavam todos deitados

Dormindo

Profundamente.

Quando eu tinha seis anos

Não pude ver o fim da festa de São João

Porque adormeci

Hoje não ouço mais as vozes daquele tempo

Minha avó

Meu avô

Totônio Rodrigues

Tomásia

Rosa

Onde estão todos eles?

- Estão todos dormindo

Estão todos deitados

Dormindo

Profundamente.

\section{EVOCAÇÃO DO RECIFE}

Recife

Não a Veneza americana

Não a Mauritsstad dos armadores das Índias Ocidentais

Não o Recife dos Mascates

Nem mesmo o Recife que aprendi a amar depois -

Recife das revoluções libertárias

Mas o Recife sem história nem literatura 
Recife sem mais nada

Recife da minha infância

A rua da União onde eu brincava de chicote-queimado e partia as vidraças da casa de

[dona Aninha Viegas

Totônio Rodrigues era muito velho e botava o pincenê na ponta do nariz

Depois do jantar as famílias tomavam a calçada com cadeiras, mexericos, namoros,

[risadas

A gente brincava no meio da rua

Os meninos gritavam:

Coelho sai!

Não sai!

A distância as vozes macias das meninas politonavam:

Roseira dá-me uma rosa

Craveiro dá-me um botão

(Dessas rosas muita rosa

Terá morrido em botão...)

De repente

nos longes da noite

um sino

Uma pessoa grande dizia:

Fogo em Santo Antônio!

Outra contrariava: São José!

Totônio Rodrigues achava sempre que era são José.

Os homens punham o chapéu saíam fumando

E eu tinha raiva de ser menino porque não podia ir ver o fogo

Rua da União...

Como eram lindos os nomes das ruas da minha infância

Rua do Sol

(Tenho medo que hoje se chame do dr. Fulano de Tal)

Atrás de casa ficava a Rua da Saudade...

...onde se ia fumar escondido

Do lado de lá era o cais da Rua da Aurora...

...onde se ia pescar escondido

Capiberibe

- Capibaribe

Lá longe o sertãozinho de Caxangá

Banheiros de palha

Um dia eu vi uma moça nuinha no banho

Fiquei parado o coração batendo 
Ela se riu

Foi o meu primeiro alumbramento

Cheia! As cheias! Barro boi morto árvores destroços redemoinho sumiu

E nos pregões da ponte do trem de ferro os caboclos destemidos em jangadas de

[bananeiras

Novenas

Cavalhadas

Eu me deitei no colo da menina e ela começou a passar a mão nos meus cabelos

Capiberibe

- Capibaribe

Rua da União onde todas as tardes passava a preta das bananas com o xale vistoso

[de pano da Costa

E o vendedor de roletes de cana

$\mathrm{O}$ de amendoim

que se chamava midubim e não era torrado era cozido

Me lembro de todos os pregões:

Ovos frescos e baratos

Dez ovos por uma pataca

Foi há muito tempo...

A vida não me chegava pelos jornais nem pelos livros

Vinha da boca do povo na língua errada do povo

Língua certa do povo

Porque ele é que fala gostoso o português do Brasil

Ao passo que nós

O que fazemos

É macaquear

A sintaxe lusíada

A vida com uma porção de coisas que eu não entendia bem

Terras que não sabia onde ficavam

Recife...

Rua da União...

A casa de meu avô...

Nunca pensei que ela acabasse!

Tudo lá parecia impregnado de eternidade

Recife...

Meu avô morto.

Recife morto, Recife bom, Recife brasileiro como a casa de meu avô

Rio, 1925 
INFÂNCIA

Corrida de ciclistas.

Só me recordo de um bambual debruçado no rio.

Três anos?

Foi em Petrópolis.

Procuro mais longe em minhas reminiscências.

Quem me dera me lembrar da teta negra de minh'ama-de-leite...

... Meus olhos não conseguem romper os ruços definitivos do tempo.

Ainda em Petrópolis... um pátio de hotel... brinquedos pelo chão...

Depois a casa de São Paulo.

Miguel Guimarães, alegre, míope e mefistofélico,

Tirando reloginhos de plaquê da concha de minha orelha.

O urubu pousado no muro do quintal.

Fabrico uma trombeta de papel.

Comando...

O urubu obedece.

Fujo, aterrado do meu primeiro gesto de magia.

Depois... a praia de Santos...

Corridas em círculos riscados na areia...

Outra vez Miguel Guimarães, juiz de chegada, com os seus presentinhos.

A ratazana enorme apanhada na ratoeira.

Outro bambual...

O que inspirou a meu irmão o seu único poema:

Eu ia por um caminho,

Encontrei um maracatu.

O qual vinha direitinho

Pelas flechas de um bambu.

As marés de equinócio.

O jardim submerso...

Meu tio Cláudio erguendo do chão uma ponta de mastro destroçado.

Poesia dos naufrágios!

Depois Petrópolis novamente.

Eu, junto do tanque, de linha amarrada no incisivo de leite, sem coragem de puxar.

Véspera de Natal... Os chinelinhos atrás da porta...

E a manhã seguinte, na cama, deslumbrado com os brinquedos trazidos pela fada.

E a chácara da Gávea?

E a casa da Rua Don'Ana? 
Boy, o primeiro cachorro.

Não haveria outro nome depois

(Em casa até as cadelas se chamavam Boy).

Medo de gatunos...

Para mim eram homens com cara de pau.

A volta a Pernambuco!

Descoberta dos casarões de telha-vã.

Meu avô materno - um santo...

Minha avó batalhadora.

A casa da Rua da União.

O pátio - núcleo de poesia.

O banheiro - núcleo de poesia.

O cambrone - núcleo de poesia (la fraicheur des latrines!).

A alcova de música - núcleo de mistério.

Tapetinhos de peles de animais.

Ninguém nunca ia lá... Silêncio... Obscuridade...

O piano de armário, teclas amarelecidas, cordas desafinadas.

Descoberta da rua!

Os vendedores a domicílio.

Ai mundo dos papagaios de papel, dos piões, da amarelinha!

Uma noite a menina me tirou da roda de coelho-sai, me levou, imperiosa e ofegante,

[para um desvão da casa de Dona Aninha Viegas,

[levantou a sainha e disse mete.

Depois meu avô... Descoberta da morte!

Com dez anos vim para o Rio.

Conhecia a vida em suas verdades essenciais.

Estava maduro para o sofrimento

E para a poesia.

\section{RECIFE}

Há que tempo não te vejo!

Não foi por querer, não pude.

Nesse ponto a vida me foi madrasta,

Recife.

Mas não houve dia em que não te sentisse dentro de mim:

Nos ossos, nos olhos, nos ouvidos, no sangue, na carne,

Recife. 
Não como és hoje,

Mas como eras na minha infância,

Quando as crianças brincavam no meio da rua

(Não havia ainda automóveis)

$\mathrm{E}$ os adultos conversavam de cadeira nas calçadas

(Continuavas província,

Recife).

Eras um Recife sem arranha-céus, sem comunistas,

Sem Arrais, e com arroz,

Muito arroz,

De água e sal,

Recife.

Um Recife ainda do tempo em que o meu avô materno

Alforriava espontaneamente

A moça preta Tomásia, sua escrava,

Que depois foi a nossa cozinheira

Até morrer,

Recife.

Ainda existirá a velha casa senhorial do Monteiro?

Meu sonho era acabar morando e morrendo

$\mathrm{Na}$ velha casa do Monteiro.

Já que não pode ser,

Quero, na hora da morte, estar lúcido

Para te mandar a ti o meu último pensamento,

Recife.

Ah Recife, Recife, non possidebis ossa mea!

Nem os ossos nem o busto.

Que me adianta um busto depois de eu morto?

Depois de morto não me interessará senão, se possível,

Um cantinho no céu,

"Se o não sonharam", como disse o meu querido João de Deus,

Recife.

Rio, 20.3.1963

Examinaremos os poemas com o objetivo de tratar comparativamente de questões que permitem refletir a respeito das relações entre o enunciador e o enunciatário na poesia autobiográfica. Num primeiro momento, será abordada a 
maneira como o passado lembrado é trazido à tona e construído nos poemas, enquanto se investiga a participação dos elementos autobiográficos na produção do sentido de cada um deles. Após esse momento analítico, será possível observar os poemas de forma comparativa, tecer algumas reflexões a respeito da escrita autobiográfica em Bandeira e talvez na própria poesia, e ainda tratar brevemente do éthos e do estilo.

Em "Evocação do Recife", na reconstrução do passado realizada pela memória, fala-se de Totônio Rodrigues, da rua da União, da casa de Dona Aninha Viegas, das brincadeiras das crianças no meio da rua, das conversas das famílias sentadas com cadeiras nas calçadas, da brincadeira de coelho-sai, do primeiro alumbramento, do avô morto, dos pregões dos vendedores de rua, do boi morto, etc. Muitas dessas figuras são recorrentes na obra de Bandeira e aparecem, assim, em outros poemas e também em Itinerário de Pasárgada ${ }^{36}$. Trata-se de uma circularidade do narrado que remete a uma circularidade da narração. A morte do avô encontramos de novo nos versos de "Infância" e de "Profundamente"; este fala ainda de Rosa, de Totônio Rodrigues, da avó, de Tomásia, da festa de São João. "Infância" retoma também a rua da União, os vendedores de rua, a avó, a brincadeira de coelho-sai, a casa de Dona Aninha Viegas. Em "Recife" deparamos novamente com as crianças que brincam no meio da rua, os adultos que conversam sentados em cadeiras na calçada, o avô materno.

Poderíamos continuar apontando os ecos de um poema no outro e mesmo mostrar sua expansão para outros textos, além desses quatro que nos propusemos a estudar. Afinal, muitas dessas figuras não se restringem a essa amostra. O "boi morto" é título do primeiro poema de Opus 10 (1993, p. 213), cuja primeira edição data de 1952. No mesmo livro, temos nos versos de "Cotovia" (p. 213-214) a rua da Aurora ("Voei ao Recife, no Cais/ Pousei da rua da Aurora"), que já conhecemos de "Evocação do Recife". A rua da União, as cheias, o Capibaribe, o cambrone aparecem, com outras figuras, nas crônicas de Andorinha, Andorinha, obra de 1966, que reúne textos publicados em revistas e jornais da época. Os "chinelinhos atrás da porta", colocados para esperar o Natal de "Infância", podem ser revistos em "Versos de Natal", de Lira

\footnotetext{
${ }^{36}$ Embora o capítulo trate da poesia de Bandeira, traremos à luz sua obra em prosa, quando a comparação entre os dois modos de fazer autobiografia se mostrar pertinente.
} 
dos Cinquent'anos (1993, p. 171), publicado pela primeira vez em 1940. É por meio dessa rede de relações e, principalmente, de repetições que a autobiografia vai sendo constituída. Sintagmas inteiros, de palavras isoladas a frases, são repetidos de um texto para o outro, num exercício de autocitação. Assim, a leitura do conjunto de poemas autobiográficos permite ao enunciatário criar para si uma imagem da infância do enunciador, espaço-tempo construído como referente interno, em que vivem o avô, Totônio, Rosa, em que é possível brincar na rua, sentar na calçada ${ }^{37}$. Esse conjunto pode ser lido, então, como um texto único, em que cada poema serve de referência a outro, sustentando a veridiç̧ão de modo peculiar.

Se olharmos para a obra maior do poeta, veremos que este poema ["Infância"] está reescrito em vários outros. A "mitologia pessoal" de Bandeira habita do primeiro ao último livro, fazendo reaparecerem personagens e acontecimentos em novos contextos. A construção desse álbum de retratos da história biográfico-poética do autor é feita ao longo de toda a obra; cada livro acrescenta peças novas à totalidade desse mosaico (ROSENBAUM, 1993, p. 68).

Nos quatro poemas escolhidos para análise, encontramos um narrador que, a partir de um tempo presente, busca recuperar a infância ${ }^{38}$. Em cada um deles isso é realizado de forma singular. Uma breve análise semiótica dos textos irá permitir observar os mecanismos que fazem com que essa época pretérita venha à tona sob simulacros diversos.

\section{1 "Profundamente": A festa e A MORTE}

O poema "Profundamente" constitui-se de duas partes, separadas tanto espacialmente, no plano da expressão (há um intervalo entre elas na página), como temporalmente, no plano do conteúdo (esse intervalo marca a passagem de um tempo para o outro). A primeira trata aparentemente de um passado

\footnotetext{
${ }^{37}$ Falamos da infância do enunciador, porque nos textos autobiográficos é produzido o efeito de identidade entre enunciador, narrador e protagonista, conforme mencionamos.

${ }^{38}$ Para a semiótica, o narrador e o narratário são actantes da enunciação enunciada delegados pelo enunciador e pelo enunciatário (GREIMAS; COURTÉS, 2008, p. 327). Tendo em vista essa definição, optamos por empregar tais noções na análise de poemas, o que não indica a falta de reconhecimento da especificidade da poesa.
} 
recente ("ontem"), e a segunda, de um passado mais remoto ("quando eu tinha seis anos") ${ }^{39}$.

No início do poema, é construída a cena da festa de São João ocorrida "ontem":

Quando ontem adormeci

Na noite de São João

Havia alegria e rumor

Estrondos de bombas luzes de Bengala

Vozes, cantigas e risos

Ao pé das fogueiras acesas.

Características sensoriais - em especial, sons e luminosidade - são evocadas: "estrondos", "rumor", "luzes", "vozes, cantigas e risos", "fogueiras acesas". A memória da festa constitui-se, então, de maneira fragmentária. O todo recordado no presente da narração vem à luz apenas por meio de alguns traços sensíveis. A festa é, então, claridade, em oposição à escuridão, e barulho, em oposição ao silêncio. Conforme esses elementos aparecem no poema, a presença da festa vai sendo restaurada. Trata-se de uma restauração principalmente das sensações causadas no sujeito, ou seja, da experiência sensível vivida por ele. O único verbo utilizado em meio à descrição é "havia", que está no imperfeito, o que cria o efeito de que o evento é vivido de dentro, em sua duração (FIORIN, 1996, p. 155).

Na passagem da primeira para a segunda estrofe, a festa é interrompida de forma inesperada, o que é reiterado por um verbo no pretérito perfeito, que possui o aspecto da pontualidade ("despertei”). O sono é o responsável pela ruptura, embora ela só seja notada pelo narrador no instante em que acorda.

No meio da noite despertei

Não ouvi mais vozes nem risos

Apenas balões

Passavam, errantes

Silenciosamente

Apenas de vez em quando

O ruído de um bonde

Cortava o silêncio

Como um túnel.

\footnotetext{
${ }^{39}$ A leitura que fazemos de "Profundamente" possui como ponto de partida a análise proposta por Arrigucci, em Humildade, paixão e morte (1990b).
} 
No nível narrativo, é desfeita a conjunção do sujeito com o objeto festa, o que é revelado por seu apagamento sensorial ("não ouvi mais vozes nem risos"). A festa dá lugar à cidade modernizada (ARRIGUCCI, 1990b, p. 215), figurativizada pela noite, pelo túnel (passagem para carros) e pelo ruído do bonde, único som a cortar o silêncio. Essa cidade não representa um novo universo denso sensorialmente, é apenas falta: "Apenas de vez em quando/ $O$ ruído de um bonde/ Cortava o silêncio/ Como um túnel". O túnel, elemento vazado, é comparado ao som produzido pelo bonde, o que somente reforça o vazio sensorial. O sujeito parece viver o estado da vacuidade ou de incompletude, definido por Tatit como:

[...] a menor densidade existencial que um sujeito pode experimentar. Tudo indica, de fato, que o enunciador se projeta no texto como alguém que sofreu um processo de esvaziamento modal e emocional e se encontra desolado e sem elã (entenda-se por isso a ausência de direcionalidade ou, simplesmente, de intenção) (2001, p. 139).

A saída da festa do campo de presença do sujeito realiza-se de forma abrupta, inesperada, e o sujeito, que se sentia pleno (realização), vivencia o sentimento de vazio (virtualização), causado pelo desaparecimento repentino da festa.

Em seguida, o narrador pergunta:

Onde estavam os que há pouco

Dançavam

Cantavam

E riam

Ao pé das fogueiras acesas?

A questão que encerra a primeira parte do poema funciona, como bem mostra Arrigucci (1990b, p. 212), como uma enumeração negativa, refazendo de maneira gradativa a saída da festa do campo de presença do sujeito. Os elementos mencionados são trazidos outra vez ao texto, mas como falta. Tal movimento de subtração não diz respeito apenas à figuratividade, mas também à "carga tensiva" do poema. Assim, a cada verso introduzido, não é apenas a 
festa que se dissolve, mas o próprio sujeito que, ao ver cada vez mais distante o objeto que o atrai, experimenta o sentimento de incompletude.

Nos termos de Zilberberg (2006a), trata-se de uma queda de intensidade. A festa, vivida como valência paroxística, vai deixando o campo perceptivo. Inicialmente, ocorre uma operação de "menos mais", uma atenuação - retira-se tonicidade. Isso dá lugar a um acréscimo de menos, a minimização: soma-se um "menos" àquilo que já está fraco se considerarmos o eixo da intensidade (operação de "mais menos"). A enumeração negativa corresponde, então, a uma gradação no nível tensivo da densidade de presença da festa, que vai sendo esvaziada. O ponto de interrogação, que dá direção ascendente à prosódia silenciosa do poema, corrobora o sentimento de falta que se instala. A estrofe é encerrada pela resposta:

- Estavam todos dormindo

Estavam todos deitados

Dormindo

Profundamente

$\mathrm{Na}$ primeira estrofe da segunda parte de "Profundamente", o narrador afirma que foi também por causa do sono que não pôde ver o final da festa:

Quando eu tinha seis anos

Não pude ver o fim da festa de São João

Porque adormeci

Em seguida, para falar sobre a distância dos entes queridos, utiliza o tempo presente e enunciativo, que é o tempo que possui como marco temporal a concomitância com o instante da enunciação: "Hoje não ouço mais as vozes daquele tempo". Com isso, aproxima-se aquilo que é narrado do sujeito da enunciação, formado pelo enunciador e pelo enunciatário, não para presentificar o passado, mas para tornar presente a sua ausência. Trata-se de uma afirmação da falta.

Hoje não ouço mais as vozes daquele tempo

Minha avó

Meu avô

Totônio Rodrigues 
Tomásia

Rosa

Onde estão todos eles?

A pergunta feita na primeira parte é retomada ("Onde estavam os que há pouco/ Dançavam/ Cantavam/ E riam/ Ao pé das fogueiras acesas?"), assim como a resposta (Estavam todos dormindo/ Estavam todos deitados/ Dormindo/ Profundamente):

Onde estão todos eles?

— Estão todos dormindo

Estão todos deitados

Dormindo

Profundamente.

Há, como vemos, uma diferença sutil, mas crucial entre a primeira vez em que a pergunta e a resposta aparecem no texto, na segunda estrofe, e essa que acabamos de mencionar: o tempo verbal. Primeiro é empregado o pretérito imperfeito ("Estavam") e, depois, o presente com aspecto durativo (“Estão"). Se os verbos coincidem quanto ao aspecto, durativo contínuo, que insere aqueles que dormem num sono congelado, não se pode afirmar o mesmo quanto ao sistema temporal de cada um. O imperfeito pertence ao sistema enuncivo, que possui um marco temporal não-concomitante ao instante da enunciação (FIORIN, 1996, p. 154), enquanto o presente concerne ao enunciativo. A primeira resposta, então, coerentemente à pergunta, afasta aqueles que dormem do presente do narrador e também do enunciador. Já a segunda os aproxima, trazendo o passado para o presente, ao menos da narração, e permitindo a conjunção temporal com a infância. Isso significa que, apesar da ausência física da festa e dos entes queridos, o vínculo temporal continua ${ }^{40}$. $\mathrm{A}$ memória feita narrativa é que permite a realização da festa outra vez no poema.

\footnotetext{
${ }^{40}$ Essa observação tem como base a análise proposta por Tatit (2001) para "Saudosa maloca", de Adoniran Barbosa: "Em razão da ausência física da maloca (e de tudo de bom que ela representava), o sujeito refaz sua relação com o objeto, estabelecendo a conjunção num plano nostálgico, no qual recupera subjetivamente aquilo que está fora do seu alcance material" ( $p$. 39).
} 
O sono é o responsável pelas rupturas vividas pelo sujeito, sua separação em relação à festa de São João e em relação ao próprio passado. Essa cisão encontra um correspondente no plano da expressão: o vazio - em termos de preenchimento de página - que existe entre as duas partes do poema, como dissemos.

Da primeira vez em que aparece no poema, a resposta dada à pergunta constitui um aumento gradativo da intensidade do sono e, numa relação inversa, uma compressão da extensidade: deitados $\rightarrow$ dormindo $\rightarrow$ profundamente. Trata-se do sono profundo, vivido como interrupção - algo que aparece de súbito, tomando o sujeito de surpresa.

Entretanto, a figura repetida do sono profundo (ela já é anunciada também no título "Profundamente" e no advérbio "silenciosamente"), que aparece na segunda resposta, aquela que encerra o poema, funciona como um mecanismo que se, por um lado, duplica a intensidade, por outro, prolonga a ausência daqueles que dormem, o que indica o aumento da extensidade. Eis a morte - vivida como falta amplificada. A repetição da gradação torna a morte, então, também extensa, indicando a permanência da ausência do passado no presente da narração ("Estão todos dormindo profundamente").

Assim, a figura do sono profundo recobre inicialmente duas cifras tensivas: o sono pontual (no nível tensivo: une alta intensidade e pequena extensidade), que o sujeito percebe como ruptura e impacto, e o sono durativo (no nível tensivo: une alta intensidade e grande extensidade), que se prolonga por todo o poema, assim como por todo o campo de presença do sujeito, que se abre para abarcar um tempo passado que dura no presente. Nem por isso esse sono profundo durativo - a morte - é menos impactante. Embora ocorra como ruptura e, assim, pontualidade na percepção sensível, a morte torna-se durativa nos eventos narrados; afinal as pessoas não irão despertar do sono profundo. Isso se comprova na sintaxe temporal, por meio da recorrência do pretérito imperfeito na primeira parte do poema.

A leitura da segunda parte faz com que a primeira ganhe novos sentidos. O advérbio "ontem", inicialmente entendido como marcador de tempo que indica o dia anterior a hoje, pode ser agora compreendido como a noite da festa de São João, quando o narrador era um menino de seis anos. Corrobora essa análise o paralelismo existente entre as duas partes: o adulto dormiu e 
não viu o final da festa assim como a criança. Logo, como observa Fiorin (2008, p. 29), "ontem" pode ser a realização de uma embreagem temporal, que consiste em utilizar um tempo no lugar de outro e que resulta na anulação da oposição existente entre eles. É interessante notar que Arrigucci também faz a leitura de "ontem" como sendo o que a semiótica entende por embreagem, mesmo sem utilizar esse conceito: "[...] tomando o mundo do passado como se fosse presente, o sujeito na verdade se reencontra consigo mesmo, com o menino que ele foi um dia [...]" (1990b, p. 227).

Assim, a utilização do advérbio "ontem" para tratar de um passado longínquo presentifica esse passado, aproximando-o da enunciação. É importante notar, no entanto, que o passado presentificado não ocupa todo 0 presente, substituindo-o por completo, mas convive com ele, preenche-o. Há um efeito de simultaneização dos tempos, já que a narrativa da memória torna possível sua coexistência. Os dois sentidos de "ontem" - dia anterior a hoje e a infância perdida - coabitam o poema, mas não com o mesmo grau de presença. Cria-se a ambiguidade própria às embreagens.

Como dissemos no início deste capítulo, os poemas "Profundamente", "Evocação do Recife", "Infância" e "Recife" podem ser considerados autobiográficos. Os elementos que nos permitem fazer essa afirmação, no entanto, não são muitos. Voltando para a primeira parte de "Profundamente", é interessante notar que não há, nela, marcas que indiquem que esse é um texto autobiográfico. O que mais se aproxima disso é o uso da primeira pessoa, que cria o efeito de identificação entre o protagonista e o narrador. Entretanto, nos textos autobiográficos, conforme mostra Lejeune (1996), existe ainda um segundo efeito de identidade, entre 0 ator e o enunciador pressuposto, realizado, por exemplo, pela coincidência do nome, entre outros recursos.

No caso de Itinerário de Pasárgada (1984), obra em prosa de Manuel Bandeira e de caráter autobiográfico, além da coincidência do nome entre o enunciador pressuposto e o protagonista, é realizada ainda uma embreagem de pessoa do tipo que confunde os níveis do narrador e do enunciador, criando a identificação entre ambos (FIORIN, 1996, p. 122-123). Essa embreagem é realizada por mecanismos diversos. Um deles é a sugestão de que é o narrador o responsável por escrever o texto, como se vê no trecho: "Confesso que já me vou sentindo bastante arrependido de ter começado estas 
memórias" (p. 29). Outro mecanismo que também gera tal efeito é a narrativa do processo de criação de certos poemas, afinal, quem os assina é Manuel Bandeira, o autor do livro, o nome na capa, que, por um efeito do discurso, torna-se idêntico ao narrador: "[...] eis o clima dentro do qual compus os versos O ritmo dissoluto [...]." (p. 72). Todos esses recursos não são empregados nem em "Profundamente" nem nos demais poemas estudados.

Com relação às marcas autobiográficas, a segunda metade de "Profundamente" é um pouco mais rica. Há a menção da infância e dos avós, que pode funcionar como elemento biográfico, além da de nomes de personagens que povoaram a infância do autor (entendido aqui como entidade implícita), como outras obras revelam. Aliás, tais nomes são a única marca que permite fazer a identificação entre 0 ator biografado e o enunciador, e isso graças à alusão intertextual. Se, por um lado, essa é uma marca frágil, por outro, esses nomes são muito recorrentes na obra de Manuel Bandeira e, assim, suficientes para traçar o vínculo e trazer à tona a infância. São mencionados no primeiro capítulo de Itinerário de Pasárgada. Além disso, fazem-se presentes em outros poemas. Temos, assim, contato com Totônio Rodrigues em "Evocação do Recife" e com Tomásia em "Recife", conforme foi comentado anteriormente. $\mathrm{O}$ avô aparece nos quatro poemas com os quais estamos trabalhando; mais do que o avô, a morte do avô está sempre presente. Essas são algumas das figuras que condensam o sentido de infância na obra de Bandeira.

Na segunda parte de "Profundamente", aparecem ainda uns poucos antropônimos, alguns sob a forma de apelidos. Não é fornecida muita informação a respeito das pessoas nomeadas: a ligação que possuem com o menino aparece somente em alguns casos ("Minha avó" ou "Meu avô") e elas não realizam nenhuma ação no texto. Essa falta de detalhamento faz com que a aparição desses nomes não contribua tanto para a criação do efeito de realidade, como de uma realidade externa à memória. Sua função é realmente a de trazer para o texto o universo da infância, de uma infância particular e única, apresentada de modo bastante subjetivo, familiar, como evidencia o uso de apelidos, do marco temporal "seis anos", em oposição a fatos históricos, por exemplo. Trata-se, assim, da infância da memória, e não exterior a ela. 
Essa forma de construir a figuratividade no poema ajuda a recriar o elo, ao menos temporal, com o passado, aproximando-o do narrador e do enunciador, o que é corroborado pelo uso do presente na segunda resposta ("Estão todos dormindo"), já discutido anteriormente. Se a morte, estado no qual se encontram os avós, Totônio Rodrigues, Tomásia e Rosa, é vivida como amplitude, a escritura das memórias permite resgatar o tempo da infância e todos os entes queridos. Entretanto, eles são evocados no poema, insistimos, somente por meio da afirmação da perda.

\section{2 “EvocAÇÃo do RECIFE”: O FLUXO dAS LEMBRANÇAS}

Como em "Profundamente", encontramos em "Evocação do Recife" as operações de aparecimento e desaparecimento do passado, cujo operador parece ser a própria memória do sujeito. Vivida no presente da narração, a memória se mantém, neste poema, como experiência predominantemente sensível. Em "Profundamente", dois tempos são colocados em tensão, o período contemporâneo ao narrador - "No meio da noite despertei" - e "Quando eu tinha seis anos". Em "Evocação do Recife", uma relação semelhante é estabelecida entre o Recife contemporâneo ao narrador e o Recife da infância.

O poema tem início com o nome da cidade "Recife", um topônimo, num verso, sozinho. O topônimo, como vimos, possui a função de ancoragem. A sua presença convoca um conhecimento comum a respeito de um lugar e constrói um simulacro de referente externo, criando certo tipo de efeito de realidade: o de que o lugar existe fora do discurso, no mundo. Nesse caso, o lugar evocado é a capital de Pernambuco. Entretanto, parece ser justamente essa função de ancoragem que o narrador deseja afastar.

Recife

Não a Veneza americana

Não a Mauritsstad dos armadores das Índias Ocidentais

Não o Recife dos Mascates

Nem mesmo o Recife que aprendi a amar depois -

Recife das revoluções libertárias

Mas o Recife sem história nem literatura 
Recife sem mais nada

Recife da minha infância

Por uma série de negativas, vai a cada verso despindo a palavra Recife desses sentidos referenciais ou trazidos por alusões intertextuais e mesmo do interdiscurso da história brasileira. Nega a "Veneza americana" dos versos de Gonçalves Dias ${ }^{41}$, ou a histórica: tomada pelos holandeses e governada por Maurício de Nassau, ou a da Guerra dos Mascates. Nega até mesmo a cidade que conheceu já mais velho. O narrador parece querer apagar a série de aprendizados adquiridos ao longo da vida, para retomar a visão que tinha quando criança de Recife, a visão das primeiras vezes. Quer de novo o que chama de "Recife sem história nem literatura", a cidade "sem mais nada", por isso a palavra sozinha lá no início dessa primeira estrofe, ou seja, esvaziada de todos esses atributos que resultam de um longo aprendizado. Ele busca a cidade da infância, marcada pela relação imediata com o mundo, ou seja, sem a projeção dos conhecimentos adquiridos que antecipam o contato com a cidade.

Para ressemantizar a relação com a cidade, o narrador deve esquecer o Recife que ocupa, no momento da narração, o seu campo perceptivo (ou enfraquecer sua presença). Mas por que o narrador não inicia o poema já tratando do Recife do passado, que é o que deseja recordar? Ao dizer que não vai abordar essa cidade referencial, o narrador acaba por trazê-la para o texto, mesmo que seja para negá-la em seguida. Usa assim a figura retórica da preterição: "A Preterição [...] consiste em fingir não querer dizer o que, contudo, é dito claramente, e frequentemente até mesmo com força" (FONTANIER, 1988 ; tradução nossa) ${ }^{42}$. Em seu Dicionário de termos literários, Massaud Moisés (1974) dá definição semelhante e acrescenta que o efeito final pode ser também de ironia: "Figura de linguagem mediante a qual o orador ou o poeta expressa francamente os termos da omissão que anuncia fazer no seu

\footnotetext{
${ }^{41}$ Gonçalves Dias, no poema "Dedicatória aos pernambucanos" (Poesias, 1926), tece elogios à cidade de Recife. Reproduzimos aqui a primeira das seis estrofes que formam essa "Dedicatória": "Salve terra formosa, ó Pernambuco,/ Veneza Americana, transportada,/ Boiando sobre as águas!/ Amigo genio te formou na Europa,/ Genio melhor te despertou sorrindo/ À sombra de coqueiros".

42 "La Prétérition [...] consiste à feindre de ne pas voulouir dire ce que néanmoins on dit très clairement, et souvent même avec force".
} 
discurso ou poema, seja para efeito de ironia, seja de realce [...]". Assim, o narrador, ao afirmar que não deseja contar sobre o Recife retratado pela literatura, pela história e pelos jornais, enfatiza a importância da cidade, sua fama, sua história, sua grandiosidade, afinal, é a "Veneza americana", é palco de revoluções libertárias. Parece que de alguma forma ele também está tomado por essa visão do Recife, o tempo passou e ele foi sendo "convencido" por ela. Há um embate entre o desejo de esquecê-la (querer) e as possibilidades de realizá-lo (poder), o que apenas torna mais intensa a sua renúncia, ao dizer que não é essa cidade repleta de glórias que deseja reencontrar.

O Recife que se apresenta para o narrador é introduzido, na primeira estrofe, por meio do apagamento das marcas enunciativas de pessoa. $O$ efeito é de objetividade e de distanciamento, uma vez que afasta o enunciado da enunciação. A aparição da cidade nomeada por meio da preterição parece pouco afetar o sujeito, que a descreve com expressões já, de certa forma, cristalizadas pelo uso. No nível tensivo, é estabelecida uma relação inversa entre a pequena intensidade e a grande extensidade, pois essa cidade constitui objeto conhecido por seus aspectos inteligíveis e por qualidades apresentadas como atemporais.

A entrada desse Recife no campo de presença do sujeito é feita de forma negativa, como vimos. Há um duplo movimento: primeiro, trazê-lo ao poema, em seguida, suprimi-lo aos poucos. Para diluir essa cidade, tirá-la do campo de presença, é preciso fazer uma operação de "mais menos", ou seja, acrescentar mais um "menos" àquilo que já é fraco, se considerarmos a intensidade com que ela afeta o sujeito que a percebe. É isso que é feito no poema por meio da recorrência da negação dos atributos da cidade: "Não a Veneza americana", "Não a Mauritsstad dos armadores das índias Ocidentais", etc. Reconhecemos aqui a "enumeração negativa", já observada por Arrigucci (1990b, p. 212) em "Profundamente".

O movimento de desnudar a cidade, afastando toda predicação vinda "de fora", corresponde não só a uma forma de comandar a saída da cidade 
contemporânea ${ }^{43}$ do campo de presença do sujeito, mas de possibilitar a chegada de um novo objeto: o Recife da infância ou ainda o "da minha infância". O pronome possessivo de $1^{\text {a }}$ pessoa é um dos elementos que cria o efeito de subjetividade e de aproximação, dominante ao longo da descrição da cidade do passado e que, além disso, contribui para o estabelecimento do elo entre o narrador e esse outro tempo. Tal efeito já começava a se imiscuir no poema a partir do 5 verso, quando o narrador diz eu ("aprendi").

É interessante que, para fazer a cidade do passado aparecer, é preciso distanciar a outra, como numa peça de teatro, quando a luz que incide sobre a cena representada na frente do palco começa a se apagar e uma outra faz aparecer, de forma gradual, um novo objeto, até então escondido na penumbra do fundo do palco. A preterição, realizada como enumeração negativa, é que controla esse jogo de luzes, permitindo enfraquecer a presença de uma das cidades, para dar espaço à outra ${ }^{44}$. Assim, enquanto a cidade contemporânea deixa o campo de presença do sujeito para tornar-se lembrança, potencializando-se, e por fim caindo no vazio virtual do esquecimento, a outra, a do passado, deixa o esquecimento para configurar-se, atualizada, primeiro como falta, dando direção ao desejo do sujeito, e em seguida, como presença plena, realizada, que o preenche.

No lugar do Recife contemporâneo e externo o narrador quer, então, colocar o da infância, do passado e da memória, sobretudo o das experiências cotidianas da criança. As ruas nas quais brincava quando garoto, aquelas que Ihe serviam de esconderijo ou as que eram palco de festas são trazidas para o texto. Não é a memória dos lugares que é narrada, mas a da própria presença do menino nesses lugares, de seu contato com cada um deles. As sensações e impressões são recuperadas. O narrador fala das vozes das meninas cantando, da raiva sentida por não poder ver o fogo, da visão da moça "nuinha", seguida de palpitação, etc.

\footnotetext{
43 Por cidade contemporânea, entendemos aquele Recife conhecido por seus valores inteligíveis pelo narrador adulto. É a cidade que, configurada inicialmente em seu campo de presença, é negada por meio da preterição para dar realce à outra.

44 A abordagem tensiva da enunciação permite lançar um novo olhar sobre a retórica. Conforme mostra Bertrand (2003b, p. 318), ela possibilita tratar o fenômeno das significações coexistentes e em competição em um mesmo enunciado.
} 
Diversas passagens confirmam a sobreposição de pontos de vista, o do narrador e o do menino. É o caso dos trechos em que o dêitico "lá" parece não apontar para nada muito definido a não ser que se entenda que o narrador faz parte da cena narrada e que mostra para o seu narratário o lugar a que se refere: "Do lado de lá era o cais da Rua da Aurora..." ou "Lá longe o sertãozinho de Caxangá". A disposição gráfica das palavras na página também pode ter efeito semelhante. Nos versos a seguir, o espaço em branco deixado na página recupera a distância do sino que tocava à noite em relação ao lugar onde estava a criança, fazendo com que narrador e narratário - e, por que não, enunciador e enunciatário - experimentem, de certa forma, essa mesma distância:

De repente

nos longes da noite

um sino

É como se o centro do campo de presença do sujeito, ocupado pelo narrador adulto, fosse pontualmente deslocado para o lugar de onde o menino percebe o mundo. $O$ adulto passa a identificar-se com a criança - um outro eu. Não só as sensações e impressões são vividas com afinidades pelo adulto e pelo menino, mas o centro dêitico, a partir de onde se constroem as referências espaçotemporais, passa a ser ocupado também por ambos. Não é apenas o Recife contemporâneo que perde densidade de presença, mas o próprio narrador adulto, conforme a presença do menino recrudesce.

A oposição entre a cidade externa, que não afeta sensivelmente o narrador, e a interna, a da memória, que leva ao engajamento de todo o seu afeto, vai sendo fortalecida ao longo do texto. O Recife da memória é aquele em que vivia o menino que não conhecia nem entendia tudo ("A vida com uma porção de coisas que eu não entendia bem/ Terras que não sabia onde ficavam"), e que experimentava o mundo sem mediação. A aparição dessa outra cidade no poema corresponde a uma relação conversa no nível tensivo, uma vez que a intensidade tônica (o sujeito é afetado sensivelmente) conjugase com a extensidade também elevada (o passado da memória apresenta-se como durativo e aberto). 
Os valores conferidos às duas cidades, a contemporânea e a do passado, ficam bastante claros quando o narrador afirma: "A vida não me chegava pelos jornais nem pelos livros/ Vinha da boca do povo na língua errada do povo/ Língua certa do povo" ou ainda quando opõe "Capibaribe", como falam os pernambucanos, e "Capiberibe" como ensinam os livros, as gramáticas, os professores ${ }^{45}$. Essa oposição minimiza a função da linguagem de criar o efeito de apontar para um referente externo, pois no poema o efeito de realidade se apoia na própria memória. Nota-se isso também no trecho em que o narrador afirma temer que as ruas da infância tenham recebido nomes novos em homenagem a personalidades e deixado de se chamar "Rua da União", "Rua do Sol", "Rua da Saudade" ou "Rua da Aurora". Os nomes das ruas da cidade da memória não são colocados no poema, preponderantemente, com o intuito de localização ou ainda para mostrar que existem no mundo. Também não é essa a função principal dos poucos antropônimos "Dona Aninha Viegas" ou "Totônio Rodrigues" que aparecem. Esses elementos trazem para o texto a infância do narrador e criam a identidade entre 0 ator biografado e o enunciador, própria dos discursos autobiográficos, conforme já mostramos.

Os versos responsáveis por trazer o Recife esquecido adquirem a extensão das lembranças e, assim, ocupam espaços variados; alguns, bastante longos, ultrapassam o limite da linha na página. Cada cena recordada surge como um bloco único e indivisível. As cenas vão se justapondo sem uma ordem aparente, criando o simulacro de que sua organização é ditada pelo próprio funcionamento da memória, e não por algum outro tipo de critério previamente estabelecido, e ainda conferindo à rememoração ritmos diferentes. As marcas de oralidade, como o uso de próclise, as repetições (a Rua da União

\footnotetext{
${ }^{45}$ Em Itinerário de Pasárgada (1984), o poeta explica a origem desses versos: "Na 'Evocação do Recife' as duas formas 'Capiberibe - Capibaribe' têm dois motivos. O primeiro foi um episódio que se passou comigo na classe de Geografia do Colégio Pedro II. [...] Certo dia, [0 professor José Veríssimo] perguntou à classe: 'Qual o maior rio de Pernambuco?' Não quis eu que ninguém se me antecipasse na resposta e gritei imediatamente do fundo da sala: 'Capibaribe!' Capibaribe com a, como sempre tinha ouvido dizer no Recife. Fiquei perplexo quando Veríssimo comentou, para grande divertimento da turma: 'Bem se vê que o senhor é um pernambucano! "(pronunciou 'pernambucano' abrindo bem o e) e corrigiu; 'Capiberibe'. Meti a viola no saco, mas na 'Evocação' me desforrei do professor". A outra intenção para a repetição era musical: "Capiberibe a primeira vez com $e$, a segunda com a, me dava a impressão de um acidente, como se a palavra fosse uma frase melódica dita na segunda vez com bemol na terceira nota" (p. 50-51).
} 
aparece diversas vezes), as correções ("Capiberibe/ - Capibaribe"), as pausas dadas pelas reticências, entre outros elementos, confirmam essa hipótese. É como se as lembranças fossem sendo narradas à medida que vão emergindo das profundezas do tempo, afinal: "Foi há muito tempo..."46. O sujeito parece não ter muito controle sobre essas irrupções.

Ele é tomado pela lembrança, numa espécie de fusão, daí a sobreposição entre o olhar do menino e o do narrador, de que já tratamos. Os contornos daquilo que é mostrado não são muito nítidos, não sabemos exatamente quem são as personagens lembradas, em que ano tudo aquilo ocorreu, onde fica cada rua. A percepção daquele que narra parece, então, regulamentada mais pela aceleração e pela concentração, assim, não é a totalidade do passado que se deixa ver, mas apenas alguns destroços que surgem de forma repentina no presente da narração.

As lembranças chegam ao poema "Evocação do Recife" de modo abrupto, configuram-se como sendo mais da ordem do acontecimento, que, numa acepção tensiva, é a combinação entre o andamento acelerado e a tonicidade impactante. Cada fragmento de lembrança representa uma fratura no presente do sujeito e, dessa forma, é inicialmente pontual. É necessário ressaltar, no entanto, que o tempo das lembranças se torna durativo quando levamos em conta sua permanência na memória.

Confirma a duratividade atribuída ao passado lembrado o uso recorrente do pretérito imperfeito, tempo verbal que possui os semas da duratividade, do inacabamento, da ausência de limite e da estaticidade e que produz o efeito, como dissemos, de que a ação é descrita de dentro de sua duração, e não observada após seu término (FIORIN, 1996, p. 155). O modo como a pontuação é empregada reforça essa aspectualização. Apenas dois pontos finais são utilizados em todo o poema, que apresenta uma enorme quantidade de reticências. A combinação da pontuação e do uso do imperfeito faz com que as experiências narradas pareçam não ter fim. Essa duratividade e esse inacabamento tanto podem ser da memória, que permite que o passado continue vivo, como também do modo como a criança vivenciava o tempo,

46 As marcas de oralidade também estão claramente associadas, nesse poema, à postura modernista de trazer para a literatura uma língua mais coloquial. Retomaremos essa questão mais adiante. 
conforme mostra a afirmação do narrador sobre a casa do avô: "Nunca pensei que ela acabasse!/ Tudo lá parecia impregnado de eternidade". O adulto que se lembra pode, então, ter a mesma experiência temporal que a criança. Evocar propicia que sinta o mesmo sentimento de eternidade e de plenitude. $O$ Recife é trazido como efeito de presença no poema, embora o tempo passado empregado para descrever a infância não permita esquecer que ele é também efeito de ausência.

Um momento de interrupção dessa duratividade, no narrado, aparece quando o narrador fala de seu primeiro "alumbramento", ao ver uma "moça nuinha no banho".

Um dia eu vi uma moça nuinha no banho

Fiquei parado o coração batendo

Ela se riu

Foi o meu primeiro alumbramento

Cheia! As cheias! Barro boi morto árvores destroços redemoinho sumiu

E nos pregões da ponte do trem de ferro os caboclos destemidos em jangadas de

[bananeiras

Novenas

Cavalhadas

Eu me deitei no colo da menina e ela começou a passar a mão nos meus cabelos

Esse trecho contribui para inserir a transformação do tempo no poema, por meio do uso do pretérito perfeito, uma vez que o aspecto perfectivo confere dinamicidade, pontualidade, acabamento e limite às ações que apresenta (FIORIN, 1996, p. 155). Assim, da duratividade da memória, passa-se à pontualidade por meio de uma série de recursos. Após esse momento vivido como algo intenso que paralisa a criança e a toma integralmente ("Fiquei parado o coração batendo"), é narrado o movimento das cheias, faz-se referência ao "boi morto", aos destroços que passam e, em seguida, é empregado novamente um verbo no pretérito perfeito, "sumiu". É retomada a descrição, agora, sem o uso de verbos ("E nos pregões da ponte do trem de ferro os caboclos destemidos em jangadas de bananeiras/ Novenas/ Cavalhadas"), sob o alto impacto das frases nominais. Em seguida, o pretérito perfeito aparece novamente ("Eu me deitei no colo da menina e ela começou a 
passar a mão nos meus cabelos"). Há, depois, uma volta ao imperfeito em "Rua da União onde todas as tardes passava a preta das bananas", mas o poema vai caminhando para um fim, assim como aquele tempo da infância.

Quando o narrador diz "Me lembro de todos os pregões", o fluxo das lembranças é interrompido. É nesse verso que o narrador se afirma como aquele que está evocando o passado a partir do presente. Até aqui, a diferenciação entre o narrador adulto e a criança não estava bem estabelecida, uma vez que o pronome pessoal eu cria identidade entre eles, assim como outros recursos já comentados. O uso de sistemas temporais distintos, o presente enunciativo e o pretérito enuncivo, instaura uma cisão entre esses "eus": "Foi há muito tempo...". Revela-se que a identidade entre o adulto e a criança só pode ser vivida sob a forma de uma tensão, ora o poema os aproxima, ora os distancia.

Me lembro de todos os pregões:

Ovos frescos e baratos

Dez ovos por uma pataca

Foi há muito tempo...

Por um momento, parece que a cidade evocada começa a retirar-se do campo de presença do sujeito, potencializando-se, voltando a seu estado de lembrança latente. Com o enfraquecimento da presença da cidade da infância, o narrador deixa de sentir-se pleno para tornar-se nostálgico: "nunca pensei que ela acabasse!". Essas palavras interrompem a sequência de versos prolongados pelas reticências "Recife.../ Rua da União.../ A casa de meu avô...". Até a maneira como esses versos são dispostos na página permite essa leitura: o segundo verso ("Rua da união...") começa embaixo das reticências do primeiro ("Recife..."), dando-Ihe continuidade; o mesmo ocorre com o terceiro ("A casa de meu avô...") que se inicia, embora na linha seguinte, na continuação das reticências do segundo. Já as palavras que falam do término daquele período (“Nunca pensei que ela acabasse!") são colocadas no início da página, interrompendo esse movimento.

Recife...

Rua da União...

A casa de meu avô... 
Nunca pensei que ela acabasse!

Efeito semelhante, de interrupção da duratividade, resulta da combinação do verso que traz o topônimo "Recife", seguido de reticências, com o verso seguinte que anuncia, sem preparação alguma, a morte do avô.

Recife...

Meu avô morto.

Recife morto, Recife bom, Recife brasileiro como a casa de meu avô

O acontecimento abrupto parece introduzir de vez o limite da duratividade da memória. O ponto colocado após "Meu avô morto" reforça o aspecto terminativo da morte. Ela é a figurativização do antissujeito, responsável pela perda da infância vivida pelo menino, assim como o final do poema figurativiza o distanciamento do narrador adulto em relação a esse menino e ainda ao Recife evocado. Talvez o poema mostre que o narrador não é mais e não pode voltar a ser essa criança ou, ao menos, que a identificação só é possível enquanto escreve suas memórias. Nota-se uma espécie de simultaneidade entre os tempos, um paralelismo é estabelecido entre a experiência vivida na infância pelo menino e a experiência vivida no poema pelo narrador adulto: o homem chega ao final do poema, assim como o menino, ao final da infância. Enunciador e enunciatário realizam o percurso com eles.

A passagem do tempo, que parecia suspensa pela ação da memória, configura-se como uma temporalidade estranha a ela, pois cronológica. Como dissemos, em "Evocação do Recife", cria-se o efeito de que as lembranças vão sendo narradas conforme emergem na superfície da memória, mas o final do poema estabelece certa cronologia, ainda que muito tênue. O imperfeito, somado a outros elementos, produz o efeito de que as imagens recordadas estão paralisadas no tempo, no sentido de que não têm começo ou fim, e não de que não possuem movimento, o que se choca com as mudanças introduzidas por elementos que significam no poema a mudança, a passagem do tempo, as interrupções. Configura-se, dessa forma, uma oposição - que não se resolve - entre uma temporalidade dinâmica, que produz o efeito de 
cronologia, e uma temporalidade estática, capaz de interromper o sequenciamento.

Os versos finais permitem ainda outra leitura, pois a sequência, "Recife..."/ "Rua da União..."/ "A casa do avô...", parece refazer o percurso tensivo realizado ao longo do poema, ao revelar a apropriação da cidade pelo narrador. O Recife da infância é o da casa do avô, absolutamente afetivo e também "eterno". Por meio da narrativa da memória, o Recife já foi ressignificado. O verso final, assimetricamente longo, se comparado a outros do mesmo poema, traz o nome da cidade com novos adjetivos, bem diferentes dos apresentados na primeira estrofe. São adjetivos que dizem respeito às experiências vividas nela. São pessoais e quase infantis, e revelam a renovação da relação que o narrador adulto possui com o Recife: "Recife morto, Recife bom, Recife brasileiro como a casa de meu avô".

O Recife bom é o que está morto, no passado, é também o da casa do avô, ou seja, aquele com o qual o narrador possui relações afetivas. É "brasileiro", porque seu. O termo "brasileiro" mostra ainda que o Recife da memória não está investido apenas de valores afetivos e familiares, mas também de certos valores desejados pelos modernistas, já que é lá que se encontram as marcas da cultura e da fala brasileiras.

É essa a cidade "do povo", afinal é nela que são vividas as experiências coletivas da festa e das brincadeiras. O último verso do poema, longo, sem ponto final e que repete três vezes a palavra "Recife", incorpora a morte dentro da duração da memória, transformando-a de pontual em durativa; de evento único, singular, em iterativo, já que ela é revivida a cada vez que as lembranças emergem no presente.

\section{3 "INFÂNCIA": A MEMÓRIA COMO VISÃO}

O poema "Infância" começa de modo abrupto: "Corrida de ciclistas". Logo vem a possibilidade de algum entendimento: "Só me recordo de um bambual debruçado no rio". Esse verso insere a primeira imagem em um passado lembrado pelo narrador, que fala a partir de um tempo presente, enunciativo ("me recordo"). O sintagma é apresentado como um fragmento da 
infância, que surge de repente. Invade o campo de presença do narrador sem qualquer preparação. O narrado sai de um estado pressuposto de virtualização, correspondente à ausência de determinada grandeza em seu campo perceptivo - o esquecimento -, e passa à realização, que tem como correlato a presença dessa mesma grandeza.

A partir daí, é construída uma sequência de imagens que parecem ser narradas à medida que vêm à memória do sujeito recordador, o que faz lembrar o poema "Evocação do Recife". A extensão dos versos também é variada, produzindo o efeito de possuírem a dimensão de cada reminiscência. Verifica-se, então, o desejo por parte do narrador de deixar-se tomar pela memória, que parece não organizar os eventos em sequência; muito pelo contrário, pode mostrá-los como simultâneos ou ligar experiências que aparentemente são muito distantes.

O que parece dificultar o contato direto do sujeito com as lembranças é o tempo, apresentado no poema como figura. Ele é o filtro que se interpõe entre o sujeito e as experiências vividas na infância. Podemos, então, entender o tempo, nesse poema, como a concretização do antissujeito.

Quem me dera me lembrar da teta negra de minh'ama-de-leite...

... Meus olhos não conseguem romper os ruços definitivos do tempo.

Apesar dos pontos comuns, "Infância" e "Evocação do Recife" são poemas que apresentam diferenças. Se "Evocação do Recife", pelo modo como as reminiscências aparecem para o narrador e ainda para o enunciador e o enunciatário, faz lembrar um filme em Super-8, que traz uma sequência de cenas do passado em um ritmo levemente entrecortado, "Infância", por seu ritmo ainda mais marcado por saltos e interrupções, pode ser comparado a um álbum de fotografias, uma vez que o efeito de congelamento das imagens é muito maior neste do que naquele poema. Esse efeito é criado principalmente pelo pequeno emprego de conectivos ligando a série de lembranças, pela organização paratática do texto (também presente em "Evocação do Recife") e pela abundância de frases sem verbos ou com verbos empregados em suas formas nominais, como em: "Corridas em círculos riscados na areia...", "Véspera de Natal... Os chinelinhos atrás da porta..." e "Eu, junto do tanque, de 
linha amarrada no incisivo de leite, sem coragem de puxar". A maneira fragmentada de reconstruir a infância confere ao poema um efeito de aceleração do conteúdo, uma vez que há um salto de uma lembrança para a outra e que, conforme já mencionamos, a entrada de cada bloco de memória no campo de presença do sujeito faz-se de forma repentina. Conforme afirma Rosenbaum, o poema solicita:

[...] uma leitura tão vertiginosa quanto a aparição das visões para o poeta. De fato, a impressão que se tem é a de que o eu lírico tem domínio apenas parcial de suas lembranças, tendo que se submeter ao material que a associação livre Ihe fornece (1993, p. 57).

"Poesia de naufrágios!", exclama o narrador, não sabemos se a respeito do tio ou de sua própria poesia, que traz pedaços da infância para a experiência presente.

Além da aceleração do conteúdo, o recurso de utilizar as formas nominais dos verbos também cria o efeito de que as imagens foram congeladas, não sofrem a ação do antissujeito (o tempo), podem ser vistas pelo narrador, assim como pelo sujeito da enunciação (enunciador e enunciatário), como no momento em que se realizavam pela primeira vez. Elas estão paralisadas. A celeridade do fluxo de lembranças se choca, portanto, com a desaceleração de cada imagem recordada.

Reforça a semelhança de "Infância" com a fotografia o fato de a visão ser o sentido que se sobressai no poema. É o que se lê no verso: "...Meus olhos não conseguem romper os ruços definitivos do tempo". Logo, como nos outros dois textos já comentados, neste também encontramos uma relação estreita entre a memória e os sentidos, com a peculiaridade de haver, em "Infância", um predomínio do sentido da visão. É como se o narrador estivesse enxergando aquelas cenas da infância novamente, junto com o menino que foi. Ele vê o que a criança via; ou a criança volta a ver pelos olhos do adulto: o pátio do hotel com os brinquedos no chão, tio Cláudio erguendo uma ponta de mastro destroçado, a ratazana enorme, a obscuridade da alcova de música, as teclas amarelecidas. Tal centralidade da visão explica por que o passado é retomado a partir da espacialidade. As imagens recriadas verbalmente parecem estar ligadas aos espaços e vêm à tona conforme o narrador se 
desloca, por meio da linguagem, pelos lugares por onde passou quando menino. É necessário enfatizar, no entanto, que os outros sentidos também são convocados, por exemplo, quando se vê tocando a "trombeta de papel" (audição), quando menciona os "tapetinhos de peles de animais" (tato), o "silêncio" da alcova de música (audição) ou "as cordas desafinadas" do piano (audição).

Essa experiência corporal propiciada pela memória vem carregada dos sentimentos da criança, como o medo da dor de arrancar o dente, o susto e o encanto diante de seu primeiro gesto de magia, o deslumbre com os brinquedos trazidos pela fada, o medo dos gatunos, o impacto do primeiro contato com a sexualidade. A infância é um período construído no poema como o encadeamento de fatos que surpreendem e encantam, um período de vivências arrebatadoras. Se os eventos são mostrados como impactantes para a criança, eles também se apresentam como afetando o narrador adulto, o que se nota na forma de organizar o texto, da qual já tratamos, que mostra as reminiscências surgindo de maneira abrupta, nas exclamações e na escolha de um léxico que conota afetividade dominante, por meio do emprego de diminutivos, dos pronomes possessivos e da interjeição "Ai" ("reloginho", "presentinhos", "chinelinho", "tapetinhos", "meu tio Cláudio", "meu avô materno", "minha avó", "Ai mundo de papagaios de papel, dos piões, da amarelinha!"). Os diminutivos possuem o papel ainda de recuperar o ponto de vista infantil sobre os acontecimentos e, somados aos possessivos, reforçam o elo entre 0 narrador e o passado.

O final do poema rompe a sequência de imagens para falar do amadurecimento:

Descoberta da rua!

Os vendedores a domicílio.

Ai mundo dos papagaios de papel, dos piões, da amarelinha!

Uma noite a menina me tirou da roda de coelho-sai, me levou, imperiosa e ofegante,

[para um desvão da casa de Dona Aninha Viegas, levantou a sainha e disse mete.

Depois meu avô... Descoberta da morte!

A saída da infância corresponde claramente a uma abertura do espaço, dada no nível figurativo. O menino deixa a casa e passa a frequentar a rua. É na rua que vive sua iniciação sexual, narrada com o emprego de quatro verbos 
no pretérito perfeito que possuem o aspecto da dinamicidade e do acabamento: "tirou", "levou", "levantou" e "disse". O acontecimento marcante, apresentado sem preparação, irrompe em um verso bastante logo, construído por orações coordenadas que devem ser lidas quase que de uma vez só. São todos recursos que alimentam a aceleração. Para a delegação de voz à menina, são enfraquecidos os limites oferecidos pelo discurso direto, no que diz respeito à falta de aspas, travessão, letra maiúscula, o que viabilizaria a pausa.

Como em "Evocação do Recife", a infância e o poema vão claramente caminhando para um fim, marcado pela morte do avô ("Depois meu avô... Descoberta da morte!"). Essa é a etapa derradeira do amadurecimento da criança. Como os outros acontecimentos vividos na infância, a morte é impactante, e talvez aqui o texto chegue à sua máxima intensidade e, assim, encontre o seu limite: "A experiência de finitude vem com a morte do avô; dada sua intensidade, apenas um verso curto, puramente nominal, sem qualquer ação que mova o leitor, fixa a imagem no impacto descrito" (ROSENBAUM, 1993, p. 69).

Com dez anos vim para o Rio.

Conhecia a vida em suas verdades essenciais.

Estava maduro para o sofrimento

E para a poesia!

Torna-se pertinente perguntar de que forma é construído no poema o amadurecimento. $\mathrm{O}$ narrador diz explicitamente que estava maduro aos dez anos para a poesia e para o sofrimento por já ter conhecido as verdades essenciais da vida, como a morte e a sexualidade. Além disso, o poema passa a ser mais temático e menos figurativo nessa última estrofe, caminhando para uma abstração maior. Elementos sensíveis são deixados de lado e no lugar são empregados termos como "verdades essenciais". As últimas linhas são bastante expositivas. Comportam períodos completos, com verbos conjugados e que possuem uma relação implicativa, diferente da que vinha sendo apresentada até então. Podemos ler nessas últimas palavras: conhecia a vida em suas verdades essenciais, estava, portanto, maduro para o sofrimento e para a poesia. Logo, o amadurecimento corresponde a uma desaceleração no nível tensivo em direção ao inteligível: a uma diminuição do envolvimento 
afetivo do sujeito, que agora já teve suas primeiras experiências, aquelas mais fortes e mais verdadeiras, segundo o narrador.

Ao final do poema, é possível perceber que o álbum de fotografias, que no início parecia seguir apenas a ordem da memória, foi sendo organizado sob o simulacro de uma forma cronológica. Essa ordenação pode ser notada, entre outros recursos, pelo emprego de advérbios e locuções adverbiais ("Ainda em Petrópolis", "Depois a casa em São Paulo", "Depois... a praia de Santos...", "Depois Petrópolis novamente", Véspera de Natal", "Manhã seguinte", "Uma noite", "Depois meu avô") e pela referência às idades (o poema se inicia com as memórias de quando tinha em torno de três anos, "Três anos?", e termina com as de quando possui dez, "Com dez anos vim para o Rio"). As mudanças de espaço topológico também contribuem para determinar a ordem em que os eventos são dispostos no texto: Petrópolis, pátio do hotel, casa de São Paulo, a praia de Santos, Petrópolis novamente, chácara da Gávea, casa da rua Don'Ana, volta a Pernambuco, a casa da Rua da União (cada lugar da casa: o pátio, o banheiro, o cambrone, a alcova), a rua, o Rio. É criada no poema uma equivalência entre o percurso espacial e o percurso temporal do ator do enunciado, já que a sintaxe do espaço contribui para organizar o tempo. Uma sequência dos fatos narrados é, então, sugerida, mesmo com pequeno emprego do pretérito perfeito.

O efeito de cronologia faz um contraponto à aceleração gerada pela ausência de conectivos, entre outros elementos, desacelerando o conteúdo por meio de uma programação previsível, que organiza a expectativa do enunciatário. Essa ordem que obedece a uma temporalidade estranha à da memória parece produzir uma tensão em relação ao modo como as imagens são construídas no poema, já que, como dissemos, em "Infância", cria-se o efeito de que as lembranças vão sendo narradas conforme surgem à memória.

Cria-se, assim, uma oposição entre a temporalidade dinâmica e a temporalidade estática, bastante frequente no romance autobiográfico e que aparece também em "Evocação do Recife", conforme já foi comentado. Embora dos quatro poemas selecionados, este seja o que possui a organização que mais se aproxima da autobiografia em prosa em relação à programação 
temporal, é nele que a tensão entre os dois tempos é mais exacerbada, já que tanto a paralisia é levada a seu extremo quanto a aceleração ${ }^{47}$.

O uso do espaço para determinar a passagem do tempo contribui também para que não seja indicado, com exatidão, o ano em que os fatos narrados ocorreram; apenas se sabe que foram vividos em um intervalo que vai dos três aos dez anos do narrador. Assim, o tempo é recriado mais como tempo autobiográfico, cujos marcadores são dados pela experiência pessoal, do que como tempo histórico. Mesmo os topônimos mantêm essa ligação com a biografia do sujeito. Não são incorporados pontos turísticos, grandes avenidas ou monumentos históricos, pois, insistimos, a ênfase do poema parece ser recriar a lembrança de um lugar ou de um tempo como experiência sensível.

\section{AS DUAS CIDADES: "RECIFE"}

Há que tempo não te vejo! Não foi por querer, não pude. Nesse ponto a vida me foi madrasta, Recife.

O poema começa com uma espécie de lamento por meio do qual o narrador mostra sua insatisfação por não ter podido "ver" a cidade de Recife: "Há quanto tempo não te vejo!". O "tu" a quem se dirige o narrador é a própria cidade, retomada a cada final de estrofe: "Recife.". Os tempos empregados nesses primeiros versos são enunciativos ("Há", "vejo", "foi", "pude", "foi"), o que aproxima a cena narrada da enunciação, produzindo o efeito de subjetividade. Contribui ainda para isso a debreagem enunciativa de pessoa, uma vez que o narrador é um eu que fala a um tu. $O$ efeito é de intimidade

\footnotetext{
47 Essa espécie de luta observada entre os dois tempos em "Infância" é um dos indícios que leva Rosenbaum a identificar no poema uma tensão entre o épico e o lírico: "De certa forma, 'Infância' se encontra na intersecção do impulso épico de fundar uma história e o modo lírico de concebê-la. Ao final, a força da recordação lírica desmonta a estrutura épica, desagregando, pela potência da emoção, os alicerces responsáveis pela objetividade narrativa. O relato acaba sendo totalmente envolvido pelo eu lírico, que se assume como absoluto construtor da história. Da sua história" (1993, p. 71).
} 
entre os parceiros da comunicação. Verifica-se que o Recife ganha o papel de actante da enunciação enunciada, tornando-se o narratário, o que cria a figura da prosopopéia. Como mostra Massaud Moisés (1974), uma das formas de "atribuir vida, ou qualidades humanas, a seres inanimados, irracionais, ausentes, mortos ou abstratos" é dirigir-se "aos seres inanimados como se fossem capazes de inteligência ou compreensão (por exemplo: ' $E$ tu, nobre Lisboa, que no mundo', Camões, Os Lusíadas, c. III, est. 57)".

O narrador se desculpa por sua ausência: "Não foi por querer, não pude,", colocando a cidade no papel do destinador-julgador. Ele parece estar modalizado por um não-poder-fazer e, ao mesmo tempo, por um querer-fazer. Tudo indica que não realizou a conjunção desejada e, assim, não cumpriu o contrato estabelecido de fazer-se presente para a cidade. Responsabiliza a "vida" que Ihe foi madrasta pela não realização da performance. É a "vida", então, que, com papel actancial definido, parece figurativizar o antissujeito. Ao desculpar-se, o narrador mostra que não é apenas ele que sente a falta da cidade, como nos outros textos já comentados, mas a cidade personificada também sofre com a ausência dele.

Como entender a ausência nesse poema? Seria uma ausência espacial causada pelo fato de o narrador não ter mais visitado Recife? A segunda estrofe aponta caminhos para possíveis respostas:

Mas não houve dia em que te não sentisse dentro de mim:

Nos ossos, nos olhos, nos ouvidos, no sangue, na carne, Recife.

Se o deslocamento espacial não pôde ocorrer, o narrador, identificado ao enunciador, está no Rio de Janeiro, como indica o topônimo que aparece ao final do poema "Rio, 20.3.1963", isso, no entanto, não impossibilita totalmente o encontro com a cidade. Lentamente, um objeto vai-se delineando no campo de presença do narrador, mas não como algo que pertence a um espaço fora do corpo, em direção ao qual ele pode mover-se, muito pelo contrário. A cidade vai aos poucos permitindo sentir sua presença. Assim, não é um objeto que pode ser delimitado, analisado, observado de longe, de maneira inteligível. Inicialmente é pura intensidade. Está no sujeito, em seus ossos, olhos, ouvidos, sangue e carne. É experiência corporal e sensorial, como fica sugerido nessa 
convocação dos sentidos e da materialidade do corpo. Ela é a substância que o constitui. Com isso, o narrador desmente a sua ausência, dada agora como pertencente à ordem do parecer, pois, na verdade, o elo que possui com a cidade nunca se rompeu. É o mesmo que ocorre nas cartas de amor em que se deseja manter a conjunção já existente entre o sujeito e seu objeto, conforme observa Carvalho:

[...] a criação do efeito de presença é uma estratégia da enunciação para fazer durar o elo. A disjunção, nesse caso, se dá mais propriamente no modo do parecer: no modo do ser, os actantes continuam em conjunção. Essa idéia pode ser assim traduzida: os amantes estão separados fisicamente, mas continuam juntos (2005, p. 128).

Mesmo assim, como veremos, o problema da falta não está inteiramente resolvido no poema. Na terceira estrofe, o objeto cidade começa a ser delimitado, caminhando para um equilíbrio entre intensidade e extensidade, possibilitado pela escritura das memórias:

Não como és hoje, Mas como eras na minha infância,

A cidade da infância é apresentada por meio dos tempos enuncivos: "eras", "brincavam", "havia", "conversavam", "continuavas", "eras", "alforriava", "foi". Ela pertence a outra temporalidade, a do narrado, e não está inserida na cena enunciativa como parceira da comunicação. Assim, o Recife que ocupa papel de narratário e de destinador-julgador, em um tempo concomitante ao "hoje", não poderia ser o mesmo que se configura como objeto buscado pelo sujeito, identificado ao narrador. Logo, como em "Evocação do Recife", encontramos nesses versos duas cidades, que não exercem os mesmos papéis actanciais. O ator Recife comporta mais de um actante, e esse sincretismo cria um jogo de ausências e presenças no poema: o narrador quer negar a presença da cidade contemporânea e fazê-la ausente, e deseja tornar presente a cidade da infância, apagando sua ausência.

A cidade à qual o narrador dirige seu querer vai sendo construída no poema em oposição à que lhe é contemporânea. É a própria escritura que 
confere densidade de presença a esse Recife primeiro, no qual "as crianças brincavam no meio rua" (e não apenas na rua), "não havia automóveis", "os adultos conversavam de cadeira nas calçadas", não havia "arranha-céus", nem "comunistas", nem "Arrais". A cidade continuava "província", possuía muito "arroz,/ De água e sal,", pertencia ao tempo em que o avô "alforriava espontaneamente". Assim, a cidade lembrada é aquela que não era só dele, mas de todos. Nela havia um convívio maior e uma espécie de mistura dos espaços públicos e privados, além de mais segurança, tranquilidade e tempo, para "papo" e diversão. Esse Recife antigo não era uma cidade grande, moderna, como fica expresso quando o narrador nega a existência dos "automóveis" e dos "arranha-céus", que figurativizam a modernidade própria das metrópoles por um processo metonímico.

A quarta estrofe continua a demarcar a cidade da infância, sempre em oposição à que é contemporânea ao narrador.

Eras um Recife sem arranha-céus, sem comunistas,

Sem Arrais, e com arroz,

Muito arroz,

De água e sal,

Recife.

A figura dos "arranha-céus", conforme já foi mencionado, recobre a isotopia temática da modernização, ao mostrar o processo de urbanização de Recife. A figura dos "comunistas" insere-se na mesma isotopia ao mesmo tempo em que permite uma releitura de "arranha-céus", pois à ausência de comunistas corresponde também a de capitalistas, metonimicamente trazidos ao poema. Assim, o passado é construído como um período em que não havia grupos políticos em confronto. Reforça tal ideia a negação da existência de "Arrais". O poema ancora-se em 1963, data que aparece logo após seu último verso. Nessa época, Pernambuco tinha como governador, Miguel Arraes, eleito em 1962 pelo Partido Social Trabalhista (PST), que contava com o apoio do Partido Comunista Brasileiro (PCB). Retomaremos essa questão mais adiante.

Nos últimos versos dessa estrofe - "Muito arroz,/ De água e sal,/ Recife" - podemos, a princípio, ler uma referência à produção agrícola do estado e 
mais especificamente à lavoura de subsistência ${ }^{48}$. Além disso, o arroz constitui a base da alimentação brasileira. Água e sal são ainda os elementos básicos na feitura do arroz e que se encontram no mar de Recife, e aí se abre a possibilidade de ler "De água e sal, Recife", como se a cidade é que fosse formada de água e sal. Todos esses sentidos apontam para uma valorização da simplicidade e daquilo que é próprio do estado de Pernambuco ou da cidade de Recife. O poema identifica "água e sal" como elementos mínimos e fundamentais da composição da cidade e que parecem não fazer mais parte do Recife contemporâneo, como se aquilo que há de mais essencial e autêntico tivesse sido deixado de lado.

A quinta estrofe continua a caracterização da cidade da memória:

Um Recife ainda do tempo em que meu avô materno

Alforriava espontaneamente

A moça preta Tomásia, sua escrava,

Que depois foi nossa cozinheira

Até morrer,

Recife.

Uma vez que é para essa cidade que aponta o desejo do narrador, notase que o modo de alforriar "espontaneamente" recebe uma valoração positiva. São eufóricas as ações tidas por desinteressadas, como a atitude do avô de libertar a escrava e a de Tomásia, que, mesmo depois de alforriada, permanece com a família. Contrapõem-se a isso os sentidos presentes em "Arrais", de guia, de líder, pois a grafia do nome com "i" e não com "e" permite compreendê-lo também como substantivo comum, conforme mostra o Dicionário Houaiss (2009): "Arrais: 1 MAR patrão ou mestre de barco de tráfego local ou portuário 2 MAR $P$ infrm. comandante de navio 3 p.ext. mestre ou patrão de qualquer tipo de embarcação (p.ex., de pesca) 4 fig. indivíduo que conduz ou guia". O poema constrói o presente como a época em que as ações e convicções são determinadas por partidos, por políticos ("Arrais" em seus dois sentidos), pela luta de classes, diferente do que para o narrador ocorria no passado, em que predominavam outros ideais. Ele cria o simulacro de um

${ }^{48}$ Singer mostra que, desde os tempos coloniais, "as atividades de mercado, constituídas geralmente por monocultura praticada em grande escala, são complementadas por atividades de subsistência, numerosas e diferenciadas, que constituem o sustentáculo daquelas [...]" (1968, p. 332). 
passado sem conflitos ou lutas de classe (a relação entre o avô e a preta Tomásia aparece como harmônica no poema), em que as escolhas eram baseadas no afeto verdadeiro e em que predominavam as relações contratuais e cordiais, bem vistas no poema.

Retomando essas estrofes que afirmam uma cidade "província" na mesma medida em que rejeitam a cidade modernizada, podemos ler o tempo presente como uma época de enfrentamentos políticos, de modernização, de urbanização e, até mesmo, de industrialização. Embora nem todas essas características apareçam de maneira explícita, fazem-se presentes em oposição ao Nordeste agrário e dos senhores de engenho, que vai sendo construído por figuras como a do arroz, da alforria espontânea e ainda da "velha casa senhorial do Monteiro", que surge na sexta estrofe. Para o narrador, o tempo passado é o período da vida "simples", sem as complexidades urbanas, da vida compartilhada, cheia de afeto e de experiências marcantes. Mas tudo isso desaparece e faz com que ele não reconheça mais a cidade da infância ou ainda que ele não se reconheça na que lhe é contemporânea. Não há conformidade possível.

O Recife primordial está investido com o valor da harmonia, e também com o da perenidade, já que a cidade da infância é mostrada como o lugar que não muda. É um objeto construído predominantemente com o pretérito imperfeito, que carrega o aspecto da duratividade, da estaticidade e do inacabamento. Na embreagem dada em "alforriava", o pretérito imperfeito é usado no lugar do perfeito, o que faz com que a ação se torne durativa, como se paralisada no tempo. A duração e a estaticidade, conferidas tanto pela debreagem quanto, de maneira mais intensa, pela embreagem, dizem respeito não só à cidade da infância em si, construída como esse lugar que não passa por transformações, mas também à permanência dessa cidade dentro do narrador. É interessante notar que o Recife que não mudava, encontra-se, no presente, totalmente transformado.

O narrador dá-se conta da impossibilidade de, no presente, retornar à cidade do passado. Diante de tal constatação, volta-se para o futuro. E no futuro encontra a morte: 
Ainda existirá a velha casa senhorial do Monteiro?

Meu sonho era acabar morando e morrendo

$\mathrm{Na}$ velha casa do Monteiro.

Já que não pode ser,

Quero, na hora da morte, estar lúcido

Para te mandar a ti o meu último pensamento,

Recife.

O narrador expressa o desejo de "acabar morando e morrendo" na velha casa $^{49}$. O emprego do gerúndio mostra que a morte resgataria o tempo durativo próprio do passado da memória, tal como construído no poema. Reitera o sema da duratividade o modo como essas duas ações, se é que podemos chamá-las assim, são apresentadas; é como se houvesse uma continuidade "natural" entre elas ou no mínimo uma espécie de equivalência; a morte não aparece, então, como ruptura. Uma vez que o desejo de ocupar a casa senhorial não pode ser realizado (“já que não pode ser”), pois essa casa faz parte da cidade que não existe mais, o narrador expressa a vontade de estar lúcido na hora da morte: "Para te mandar a ti meu último pensamento,/ Recife". Para a cidade da memória, interiorizada, o narrador só poderia enviar um "pensamento", algo que também permanece no espaço interno do sujeito. É a morte que representa no poema a possibilidade de retorno ao que já é conhecido e de encontro com a plenitude que ele acredita ter vivido na infância.

Podemos agora entender melhor a acusação feita nos primeiros versos à "vida madrasta", pois, percorrendo o restante do poema, notamos que não seria possível para o narrador retornar espacialmente à cidade da infância por ela ter sido transformada em outra. A responsável por essas transformações é a vida, que, no nível tensivo, corresponde à ruptura. Será apenas na morte que ele poderá voltar ao Recife da memória. A morte é, então, a duração, o retorno à visão das primeiras vezes, apresentado pelas figuras que se repetem na obra de Bandeira na temporalidade do narrado (as brincadeiras na rua, as conversas na calçada, o avô, etc.). É a morte que possibilitará a recuperação

\footnotetext{
${ }^{49}$ A casa do Monteiro é mencionada também em Itinerário de Pasárgada (1984): "Dos seis aos dez anos, nesses quatro anos de residência no Recife, com pequenos veraneios nos arredores - Monteiro, Sertãozinho de Caxangá, Boa Viagem, Usina do Cabo -, construiu-se a minha mitologia, e digo mitologia porque os seus tipos, um Totônio Rodrigues, uma D. Aninha Viegas, a preta Tomásia, velha cozinheira da casa de meu avô Costa Ribeiro, têm para mim a mesma consistência heróica das personagens dos poemas homéricos" (p. 21).
} 
definitiva das experiências únicas da infância, conferindo extensidade àquilo que é intenso.

Já a temporalidade da narração está repleta de figuras não recorrentes nos poemas de Bandeira e que explicitam o diálogo com outros textos. É o lugar do inteligível, do saber que nasce de experiências mediatizadas. Traz elementos que não pertencem a esse universo que vinha sendo construído e que, assim, alimentam outras formas de verdade. Encontra-se na quarta estrofe, por exemplo, o político Arraes, governador de Pernambuco na época em que foi escrito o poema, fala-se das lutas políticas ("sem arranha-céus, sem comunistas"), da produção agrícola do estado e de suas mudanças.

Entretanto, é preciso observar que esses elementos não vêm acompanhados de datas precisas, de endereços e mesmo de nomes completos, cargos, entre outros dados. Além disso, Arraes torna-se "Arrais" e ganha assim um sentido duplo, próprio da palavra poética, e ainda traz para o poema a sonoridade da fala, em oposição à correção ortográfica. O nome faz parte do mesmo verso de "arroz" e da mesma estrofe de "arranha-céu", construindo com essas outras palavras a figura sonora da aliteração. A função poética parece sobrepor-se, assim, à referencial. Reforça tal afirmação o fato de haver poucos topônimos no poema. Além do próprio nome da cidade, repetido a cada final de verso, há a "casa senhorial do Monteiro". Com relação aos antropônimos, o único evocado para a construção da cidade da infância é "Tomásia". Mas não se pode ignorar que, apesar da presença do nome, a força da ancoragem, da ordem do inteligível, mantém-se baixa. Tomásia era um nome comum na época, de muitas escravas e ex-escravas. Além disso, não há muitos atributos sensíveis que definem esse ator tanto nesse poema como nos outros. Assim, a figura "Tomásia" é tomada por seu papel temático, o de exescrava que vive na casa do patrão. Processo semelhante ocorre com outros atores, como o avô, que nunca é apresentado pelo nome.

A estrofe que fecha o poema inicia-se com uma interjeição ("Ah"), dirigida à cidade. Por meio dela, o narrador parece lamentar que seus ossos não sejam enterrados em Recife, fazendo uma citação da frase que teria sido dita por Cipião Africano e que foi retomada por inúmeros escritores, entre eles, 
Camões e Padre Antonio Vieira ${ }^{50}$. Esses autores a utilizam em sua forma integral: "Ingrata pátria, non possidebis ossa mea". Cipião Africano teria mandado gravar tal sentença na lápide de seu túmulo, pois, após ter vencido importantes batalhas para Roma, acabou morrendo em terras estranhas, sem ter sua glória reconhecida. Essa citação traz para o texto tanto o sentimento de desterro, quanto o da falta de reconhecimento. O modo como a cidade interpretou as ações do narrador é criticado, pois ela não soube avaliar a dedicação que ele the destinou. Há uma inversão da sanção. Todo o poema pode ser lido agora como a expressão da sanção cognitiva do narrador a essa cidade, que não interpretou corretamente que o elo entre ele e o Recife primeiro nunca fora rompido. Está aí uma das diferenças cruciais entre esse texto e os anteriores. Os outros três parecem centrados, no que diz respeito ao nível narrativo, na performance, ou seja, na construção do objeto passado (embora os valores investidos nesse passado se alterem), já "Recife" é um poema de predominância da sanção.

A recuperação das palavras em latim, o que em princípio poderia trazer alguma pompa ao texto, é realizada em tom levemente jocoso:

Ah Recife, Recife, non possidebis ossa mea!

Nem os ossos nem o busto.

Que me adianta um busto depois de eu morto?

Depois de morto não me interessará senão, se possível, Um cantinho no céu,

"Se o não sonharam", como disse o meu querido João de Deus, Recife.

Recife não receberá nem os ossos nem o busto do poeta. O narrador, além de se referir a uma possível sanção pragmática negativa que será endereçada à cidade (não receber os seus ossos), recupera nessa estrofe um elemento da biografia de Bandeira, que diz respeito a uma polêmica ocorrida em 1958 envolvendo o seu "busto" (seria na verdade uma cabeça). Com isso, faz uma alusão intertextual a artigos e reportagens publicados na época, e mesmo às crônicas do autor. Destacamos o texto "Caso da cabeça" (Andorinha, andorinha, 1986, p. 24-27) em que são dadas respostas às

${ }^{50}$ Camões retoma as palavras de Cipião em sua "Carta da Índia" (ANDRADE, 1977, p. 152153), depois de ter vivido a experiência da prisão em Portugal. Vieira menciona-as para justificar o fato de Santo Antonio ter tido que deixar a pátria (VIEIRA, 2003, p. 428). 
acusações de Mário Melo. Melo, jornalista pernambucano e um dos principais opositores à homenagem que seria feita à Bandeira, escreveu em artigo publicado no Jornal do Commercio, em 12 de março de 1958, que o "busto" era inconstitucional, pois homenageava uma personalidade em vida, o que se chocaria com o artigo 191 da Constituição do Estado de Pernambuco. Pelo instrumento legal, ficava proibido pôr nome de pessoa viva em localidade ou logradouro. Além disso, o jornalista acusou Manuel Bandeira de ter esquecido o Recife:

Que ele venha ver a terra de sua meninice, depois de tantos anos de esquecimento, é coisa louvável. Que venha, porém, para assistir à inauguração de seu busto na Rua da União, de acordo com o projeto Nilo Pereira, tenho minhas dúvidas (MELO, 1958).

Assim, "Recife", ao revelar que o narrador nunca se distanciou da cidade primeira, torna-se um "poema resposta" às acusações feitas na época.

O poema é encerrado com um verso do poeta português, João de Deus: "Se o não sonharam"1. Ao citar o poeta e ainda a frase atribuída a Cipião Africano, incorporada antes por diversos escritores, o narrador confere a si o lugar daquele que conhece a tradição e participa dela, é o escritor, o poeta que fala no texto. Além disso, a apropriação das palavras de João de Deus faz com que se identifique com aquele que é humilde e valoriza as coisas simples da vida. Por meio delas, expressa o seu desejo de, após a morte, encontrar um "cantinho no céu". O vocativo que fecha a estrofe derradeira pode ser lido também como uma espécie de aposto que explica qual seria esse cantinho: "Recife". A cidade narratária é, de certa forma, "invadida" por aquela que é objeto de busca do narrador.

Com essas observações, retomamos a questão inicial a respeito do sentido da ausência do narrador no Recife. De que adiantaria visitá-lo "hoje", se o narrador não encontraria lá a cidade que busca? Mesmo se um deslocamento espacial fosse realizado, ele não tornaria a ver o lugar querido e a ausência

\footnotetext{
${ }^{51}$ Reproduzimos a terceira estrofe do soneto em que o verso aparece. O soneto constitui o início do poema "A vida", de João de Deus (1990): "Alma gémea da minha, e ingénua e pura/ como os anjos do céu (se o não sonharam...)/ quis mostrar-me que o bem bem pouco dura!".
} 
sentida não seria menor. O narrador, então, cumpriu sua parte do contrato, pois guardou dentro de si a cidade da infância e, mais do que isso, resgatou-a inúmeras vezes em outros poemas, principalmente em "Evocação do Recife", que se inicia com o nome da cidade sozinho no verso, exatamente como o encontramos ao final de cada estrofe de "Recife", a não ser pela presença do ponto final neste último. O poema, ao fazer esse resgate e ainda o de inúmeras figuras que aparecem em textos anteriores de Bandeira, revela que a ausência do próprio sujeito autobiografado em relação ao Recife, reconstruído pela memória, é da ordem do parecer, conforme já foi comentado. Ele nunca teria deixado de fazer visitas à cidade, mas foram visitas literárias, as únicas possíveis de se fazer a um lugar desaparecido no tempo.

Já da cidade não se pode dizer o mesmo. Há um contrato implícito que vai se explicitando ao longo do poema por meio da condenação do narrador à cidade contemporânea. Nesse contrato, o narrador atua como destinadorjulgador e a cidade como sujeito julgado. A performance do sujeito é avaliada de forma negativa, pois não cumpriu o que se esperava dele, já que a cidade que o representa não está presente para o narrador, uma vez que se transformou em outra. No jogo bastante complexo de ausências e presenças, estabelecido no poema, parece ocorrer, então, uma inversão. Se num primeiro momento, é o narrador que se desculpa por estar ausente, ao final verificamos que a ausência é atribuída ao Recife.

\section{CONSIDERAÇÕES FINAIS: OS POEMAS AUTOBIOGRÁFICOS}

Nos quatro poemas analisados, o passado se apresenta como o período das experiências fundamentais, cujos efeitos são sentidos ainda no presente da narração pelo adulto que recorda. É, então, formado por um conjunto, relativamente desordenado, de eventos impactantes que tocam o sujeito da percepção, não apenas a criança, mas também o narrador. Um trecho de "Infância" exemplifica a perspectiva do adulto, que direciona seu interesse para o passado; e o outro, a perspectiva da criança, que acredita comandar o urubu com sua corneta. Os eventos são narrados na ordem que ela os vivencia. 
Só me recordo de um bambual debruçado no rio.

O urubu pousado no muro do quintal.

Fabrico uma trombeta de papel.

Comando...

O urubu obedece.

Fujo, aterrado do meu primeiro gesto de magia.

Há em muitas passagens, no entanto, a identificação entre o modo de ver o mundo da criança e o do adulto, ou seja, parece que o narrador consegue retomar o olhar infantil por alguns instantes, como se a criança viesse ocupar 0 centro do campo de presença do adulto.

Em "Evocação do Recife", conforme dissemos, o adulto que se lembra pode ter a mesma experiência temporal que a criança. Ao recordar, ele também revive momentaneamente os sentimentos de eternidade e de plenitude próprios da infância. Diversos recursos produzem essa concordância de pontos de vista, como a disposição gráfica das palavras na página. Nos versos a seguir, por exemplo, recupera-se a distância do sino que tocava à noite em relação ao lugar onde estava a criança:

De repente

nos longes da noite

um sino

Em "Profundamente", encontramos o narrador que assume a visão infantil por meio da equivalência que se estabelece entre os tempos. $\mathrm{O}$ adulto e a criança vivenciam "juntos" a interrupção da festa pelo sono profundo. Em "Infância", além do uso dos diminutivos que evocam o olhar da criança, o poema propicia ao narrador a vivência "simultânea" à do menino das diferentes fases da infância e de seu fim, como observamos ao longo da análise. Em "Recife", a cidade evocada é aquela que pode ser sentida, que é puro afeto, como era o Recife do passado para o menino. Logo, é possível notar que os valores relacionados à percepção infantil dos eventos são buscados pelo narrador, por meio da rememoração. Ele quer outra vez que a vida seja percebida como impacto e ao mesmo tempo duração, quer que a criança possa ser revivida. 
Com relação à rememoração da infância em Bandeira, ela se configura como sendo da ordem do acontecimento (ZILBERBERG, 2007b). O sujeito não tem tempo de prever a entrada de uma determinada grandeza em seu campo de presença. Sua chegada é percebida como súbita e inesperada, abalando-o integralmente. Ele é tomado pelo objeto, numa espécie de fusão, torna-se o sujeito do sentir e não do agir. Nessa fusão, confirma-se como dominante o crescendo da emoção.

No que diz respeito à extensidade, o acontecimento corresponde ao tempo breve, quase sem duração, e ao espaço concentrado, revelando uma relação inversa entre a extensidade e a intensidade. Entretanto, cada fragmento de lembrança que emerge, embora represente uma fratura no presente do sujeito e assim seja inicialmente intenso e pouco extenso, torna-se extenso na medida em que revela sua permanência na memória.

A memória vista como acontecimento justifica a sua fragmentação nos poemas. A percepção do sujeito é regulamentada pela aceleração e pela concentração, assim, não é a totalidade do passado que se deixa ver, mas apenas alguns destroços que surgem de forma repentina no presente da narração. Essa maneira de habitar o mundo é também responsável pelo esfacelamento das fronteiras entre o narrador adulto e o menino:

Se observada a tensão que regula a junção do sujeito com o objeto, poderemos encontrar um objeto nocivo e desejável simultaneamente, valorizado segundo uma percepção comandada por certo andamento mais célere, o que resultará na diluição cada vez maior dos contornos; menos célere, o que resultará na expansão do olhar para um mundo reinstaurado na inteligibilidade dominante. Neste último caso, teremos um mundo-objeto convertido para o estado de numeroso, pois preservado segundo a nitidez dos contornos (DISCINI, 2009, p. 8).

A condensação do tempo e do espaço, assim como a aceleração e a tonicidade elevadas ocorrem em graus diferentes nos textos estudados. Basta recordarmos a análise feita de "Infância", que traz os eventos por meio de gerúndios e particípios, dando o efeito de que estão congelados, fora do tempo e do espaço, num máximo de condensação desses elementos, o que já não encontramos em outros textos, como em "Recife" ou "Evocação do Recife", que apresentam predominantemente essa paralisação por meio do pretérito 
imperfeito. Assim, nos quatro textos, os eventos lembrados aproximam-se do lugar tensivo do acontecimento, mas em graus diversos. Mesmo no interior de cada poema, é importante observar que há uma oscilação da percepção do sujeito e que os fatos às vezes são recebidos como mais impactantes e outras como menos, conforme revelam os trechos de "Infância":

Ninguém nunca ia lá... Silêncio... Obscuridade...

Uma noite a menina me tirou da roda de coelho-sai, me levou, imperiosa e ofegante, [para um desvão da casa de Dona Aninha Viegas, levantou a sainha e disse mete.

No primeiro verso, o pretérito imperfeito atribui duratividade a essa ausência discursivizada de pessoas. É um trecho com inclinação descritiva, menos intenso do que o que encontramos na segunda citação. Nesta, o uso do pretérito perfeito, somado à sequência de ações realizadas apenas pela menina, sugere que o garoto está tomado pelo evento sem qualquer reação. Sua passividade é ressaltada frente à atitude da menina (ROSENBAUM, 1993, p. 28), o que revela um impacto maior.

A ruptura que a memória exerce no presente da narração também é marcada pela diferença de isotopias figurativas para retratar o presente e 0 passado. Como fomos mostrando em cada poema, a fase das vivências essenciais é construída de forma bastante sensorial, em oposição ao presente, mais inteligível. Em "Profundamente", as cores, as formas e os sons que formavam a festa de São João dão lugar ao vazio cortado apenas pelo "ruído de um bonde". A isotopia da festa de então é substituída pela da modernização. Em "Evocação do Recife", nega-se a cidade dotada de predicados recebidos ao longo da História, para que seja afirmado o Recife experimentado sem mediações, cheio das palavras vindas "da boca do povo", dos pregões dos vendedores, das risadas das famílias, o que mostra bem a riqueza sonora. É afastada a capital de Pernambuco, para que possa ser aproximada a capital da infância. Em "Infância", o universo bastante icônico do passado se contrapõe à última estrofe, que fala do amadurecimento e é, predominantemente, temática. Em "Recife", poema que dá maior espaço ao presente, a cidade contemporânea ao narrador é apresentada como a metrópole moderna e racionalizada em oposição ao Recife provinciano da 
infância, que pode ser sentido "Nos ossos, nos olhos, nos ouvidos, no sangue, na carne".

A memória em Bandeira é, portanto, experiência estésica (GREIMAS, 2002), assemelhando-se ao que vimos em Nava. Ela rompe o presente do narrador, operando uma mudança de isotopias; instaura inicialmente uma descontinuidade temporal e espacial; converte a relação de disjunção entre o sujeito e o objeto, no caso, o passado, em uma relação de conjunção e mesmo de fusão, e estabelece uma relação sensorial entre sujeito e objeto. Além disso, fomos mostrando ao longo da análise que a rememoração possui um percurso passional, que passa pela espera, pelo momento de plenitude e pela nostalgia da perfeição entrevista. Essas etapas podem ser homologadas ao percurso que vai da falta atualizante para a plenitude realizante e, por fim, para a perda potencializante (inanidade), ou seja, da dêixis da presença para a dêxis da ausência.

Algumas afirmações do narrador explicitam a visão do passado como tempo de poesia e assim de fruição. É o caso das estrofes citadas, a primeira de "Evocação do Recife" e a segunda de "Infância":

Rua da União...

Como eram lindos os nomes das ruas da minha infância

Rua do Sol

(Tenho medo que hoje se chame do dr. Fulano de Tal)

A casa da Rua da União.

O pátio - núcleo de poesia.

O banheiro - núcleo de poesia.

O cambrone - núcleo de poesia (la fraicheur des latrines!).

A alcova de música - núcleo de mistério.

Nota-se que, em Bandeira, essas experiências estésicas são propiciadas pela memória do cotidiano. Assim, a fratura que se abre no presente do narrador para transportá-lo a um universo mais cheio de sentido é realizada pela rememoração de vivências comuns. Ao apontarem algumas componentes da "voz lírica" dos poemas de Bandeira, afirmam Antonio Candido e Gilda de Mello e Souza no "Prefácio" escrito à obra do autor: 
Uma delas é, por exemplo, certo tipo de materialismo que o faz aderir à realidade terrena, limitada, dos seres e das coisas, sem precisar explicá-los para além da sua fronteira; mas denotando um tal fervor, que bane qualquer vulgaridade e chega, paradoxalmente, a criar uma espécie de transcendência, uma ressonância misteriosa que alarga 0 âmbito normal do poema (1993, p. 3).

O cotidiano é dado por um ir e vir da memória, responsável pelo aparecimento e o deparecimento do passado. Esse movimento, que promove as oscilações entre a dêixis da ausência e a da presença e que, assim, reconstrói a ação da memória, pode ser localizado em cada poema ou em seu conjunto, já que diversas figuras ou ainda configurações discursivas migram de uma obra para a outra em Bandeira. Assim, é possível repensar a totalidade dos poemas como um texto da memória elaborado ao longo da vida. Não é apenas a vida lembrada que se apresenta como matéria autobiográfica, mas a própria memória, encenada por essas repetições. A memória se constrói, em Bandeira, como um tecido que deixa ver seu avesso, o caminho por onde passa sua trama.

É necessário frisar que as configurações discursivas, conforme reaparecem, vão ganhando novos sentidos. Barros compara a composição do semema e a relação entre semema e lexema com a organização semântica do discurso para explicar as configurações e os percursos figurativos:

No semema, há um mínimo sêmico invariante, na figura nuclear, e variação contextual tanto de traços figurativos, quanto de classemas "abstratos", que fazem prever percursos semêmicos, contextualmente diferentes, para um mesmo lexema. Define-se configuração discursiva como uma espécie de "lexema do discurso", que subsume vários percursos figurativos e temáticos, além dos narrativos, e conta com algumas figuras invariantes (2002, p. 119-120).

A autora chama a atenção para o fato de que uma determinada configuração discursiva, como a do "dedo furado", que aparece no conto da Branca de Neve e no da Bela Adormecida, possui figuras que permanecem em ambos os textos e que permitem identificá-la, embora também possua variação temática, narrativa e figurativa. Mostra que os traços ligados à figura da perfuração (instrumento pontiagudo, sujeito perfurador humano, etc) são 
mantidos, mas que na Branca de Neve o espaço é aberto e é salientada a oposição cromática entre o vermelho e o branco, enquanto na Bela Adormecida o espaço é fechado e dá-se ênfase ao som da roca. Isso comprova as variações do percurso figurativo. É, porém, possível mencionar ainda as variações temáticas, já que na Branca de Neve tal configuração recobre os temas da criação (sacrifício materno de dar a vida/ produção do belo) e da informação (previsão de acontecimentos) enquanto, na Bela Adormecida, os da curiosidade e da traição. Há ainda as variações narrativas: na Branca de Neve, ocorre a doação de competência e de existência modal e semântica e, na Bela Adormecida, a privação do objeto valor "vida".

Partindo dessas observações, torna-se possível afirmar que, em Bandeira, encontramos "motivos" da memória, ou ainda "motivos" próprios, que passam de um poema para o outro. Eles recobrem às vezes percursos temáticos e narrativos diferentes, além de, em alguns casos, trazerem certas variações figurativas. É possível falar também das diferenças tensivas que os "motivos" ou configurações discursivas expõem. Não é nosso objetivo fazer um exame minucioso dessas variações, mas mostrar o procedimento e seu papel na poesia autobiográfica. Daremos, portanto, apenas alguns exemplos para justificar o que dissemos a respeito das mudanças de sentido que as configurações sofrem de um poema para o outro.

A "rua da União" é mencionada quatro vezes em "Evocação do Recife". Aparece primeiro como o lugar das brincadeiras. Em seguida, é ressaltada a beleza do nome da rua, em oposição aos nomes que foram dados depois em homenagem a pessoas importantes. Na terceira vez em que surge, a rua é palco para toda a movimentação e barulho que trazem os vendedores. Essa configuração discursiva apresenta-se, então, como espaço aberto, ruidoso. Recobre o percurso temático da singularização do passado da memória e o percurso narrativo da construção da infância lembrada, objeto que carrega os valores da plenitude, da ingenuidade e do compartilhamento. Em sua última aparição no poema, a rua da União confirma-se como configuração que singulariza o passado lembrado. Afinal não é um Recife qualquer que é evocado, mas o da rua da União, o da casa do avô. 
A rua da União onde eu brincava de chicote-queimado e partia as vidraças da casa de Rua da União...

[dona Aninha Viegas

Como eram lindos os nomes das ruas da minha infância

Rua da União onde todas as tardes passava a preta das bananas com o xale vistoso [de pano da Costa

Recife...

Rua da União...

A casa de meu avô...

A rua da União é reencontrada ainda em "Infância", para caracterizar a casa rememorada como lugar da poesia. Diferente do que se viu no outro poema, o espaço é fechado. A casa da rua da União recobre o percurso temático da construção da infância lembrada, que carrega os valores essenciais à vida, como deixa claro o final do poema em que se diz que a criança aos dez anos já se encontrava madura para a vida e também para a poesia.

A casa da Rua da União.

O pátio - núcleo de poesia.

O banheiro - núcleo de poesia.

O cambrone - núcleo de poesia (la fraicheur des latrines!).

A alcova de música - núcleo de mistério.

Tapetinhos de peles de animais.

Ninguém nunca ia lá... Silêncio... Obscuridade...

O piano de armário, teclas amarelecidas, cordas desafinadas.

Em "Evocação do Recife", fala-se das famílias que "tomavam a calçada com cadeiras, mexericos, namoros, risadas" e ainda da meninada que "brincava no meio da rua". Em "Recife" isso é retomado:

Não como és hoje,

Mas como eras na minha infância,

Quando as crianças brincavam no meio da rua

(Não havia ainda automóveis)

E os adultos conversavam de cadeira nas calçadas

(Continuavas província,

Recife).

Se, na primeira vez em que surgem, essas figuras recobrem a isotopia temática do cotidiano, mostrando os hábitos das pessoas na época descrita, 
na segunda vez elas vêm se opor àquelas que recobrem a isotopia temática da modernização. Em "Recife", mais do que mostrar os hábitos dos moradores, elas revelam que a cidade já não é mais a mesma.

A configuração discursiva da festa também atravessa de um poema para o outro, às vezes se mostra de maneira mais expandida, às vezes mais concentrada. Em "Evocação do Recife", a sequência de ações lembradas deixa ver com maior número de detalhes a festa de São João, uma representação metonímica da cultura popular brasileira, que, de acordo com o poema, estaria mais viva no passado. Em "Profundamente", a festa é apresentada apenas por alguns atributos sensíveis. Não há quase ações lembradas, mas principalmente aspectos sensoriais. A festa de São João figurativiza tanto a cultura popular brasileira, como também a vida.

Uma pessoa grande dizia:

Fogo em Santo Antônio!

Outra contrariava: São José!

Totônio Rodrigues achava sempre que era São José.

Os homens punham o chapéu saíam fumando

$E$ eu tinha raiva de ser menino porque não podia ir ver o fogo

("Evocação do Recife")

Quando ontem adormeci

Na noite de São João

Havia alegria e rumor

Estrondos de bombas luzes de Bengala

Vozes, cantigas e risos

Ao pé das fogueiras acesas.

Hoje não ouço mais as vozes daquele tempo

Minha avó

Meu avô

Totônio Rodrigues

Tomásia

Rosa

Onde estão todos eles?

("Profundamente")

Seria possível dar continuidade ao exame dessa rede de lembranças e lacunas que vai se tecendo ao longo da obra de Bandeira. O avô, por exemplo, morre outra vez para o menino e para o narrador a cada poema autobiográfico, mas não se pode deixar de notar que ele revive também. A escritura da 
memória pode ser vista, então, como uma prática, uma ação que se reitera e que faz-ser o passado no presente. Entendida dessa maneira, pode ser aproximada do rito. Para Rosenbaum (1993, p. 192), a vivência do tempo em Bandeira revela a intersecção entre duas perspectivas temporais distintas, a histórica, em que o tempo é visto como único e contínuo, e a ritualística, dada pelas repetições rítmicas que propiciam a reatualização de um passado intemporal na poesia.

De fato, observa-se em Bandeira um tempo apresentado como linear, que traz transformações, tornando a vida a cada dia menos cheia de sentido (temporalidade dinâmica). Esse tempo que passa pode ser notado por inúmeros recursos que criam nos poemas o aspecto da pontualidade e da dinamicidade, como o emprego de alguns pontos finais ou do pretérito perfeito, que se torna recorrente, por exemplo, quando os poemas "Infância" e "Evocação do Recife" começam a caminhar para o final. Ele também se deixa apreender na construção de isotopias temáticas e figurativas diferentes para apresentar o passado e o presente. Assim, num nível de concretude maior do sentido, é mostrada a transformação de uma época na outra. Já o tempo ritualístico (temporalidade estática) elabora-se por meio das repetições da expressão e do conteúdo, próprias da memória, e do ir e vir dos "motivos" que transitam entre os poemas, de que já tratamos. O convívio entre essas duas perspectivas temporais tem consequências para a veridicção dos poemas de Bandeira, uma vez que promovem experiências temporais também distintas, tanto para o enunciador quanto para o enunciatário.

A tensão entre as duas temporalidades parece expressar bem aquilo que é próprio à paixão da saudade. Se há uma característica que perpassa o enunciador em todos os poemas analisados é o fato de projetar um éthos saudoso, constituído pela incompletude própria ao autobiógrafo. Esse tempo que chamamos dinâmico recupera a trajetória da perda: ele é inexorável, irrepetível, possui uma direção única. Ao menos nos poemas analisados, observa-se que o sentido cronológico do tempo corresponde ao esquema tensivo da decadência: à medida que as experiências se repetem ao longo da vida, elas perdem intensidade. O presente é um vazio de sentidos, se comparado ao passado. Assim, conforme o tempo cronológico avança, o sentimento de falta amplia-se. Cabe ao poeta ressignificar o seu presente por 
meio da rememoração do passado. É, então, a temporalidade estática que exprime - até mesmo ritmicamente - o desejo de conjunção, de retorno, de manutenção. Para refazer o elo perdido são empregados ainda outros recursos, como, por exemplo, o léxico que evoca o olhar infantil (uso de diminutivos e de diversas expressões como "Totônio Rodrigues era muito velho", "Uma pessoa grande dizia" ou "brinquedos trazidos pela fada").

A saudade pressupõe uma perda e o sentimento de incompletude daquele que a experimenta, conforme mostramos. O sentimento gerado pela falta pode dar origem a um programa para sua liquidação, em que o sujeito que sofreu a perda torna-se o sujeito do fazer. Por meio da lembrança, ele pode refazer a conjunção temporal com valores investidos no passado. Entretanto, a lembrança também carrega a disjunção espacial e, assim, a certeza da irreversibilidade do tempo e da morte. Por isso, a saudade não se extingue. Ela coloca em tensão a presença da lembrança e a ausência do passado. Retomando as duas organizações temporais de que tratamos, vemos que a sua coexistência nos poemas indica, por um lado, a manutenção da lembrança, a possibilidade de repetir o passado de alguma forma e, por outro, sua falta irresolúvel. Podemos falar em Bandeira de uma saudade tônica, no sentido de que essa emoção expressa, na totalidade considerada de poemas, a relação conversa entre a intensidade e a extensidade. A amplitude parece definir essa paixão que perpassa os quatro poemas de que tratamos e que dura, mas que nem por isso perde sua força. O campo de presença se dilata, assim como a intensidade da perda, no que diz respeito à saudade vivenciada em Bandeira.

Conforme mostramos, é da vida cotidiana do passado que o narrador sente saudade. O cotidiano é recuperado não apenas por meio da figuratividade, mas também pela incorporação dos falares populares, informais e prosaicos. Todos esses elementos não são apresentados como aquilo que se dessemantizou pelo uso, pelo contrário, são assumidos pelo enunciador como o que pode renovar a poesia e, ainda, sua relação com o mundo, em oposição ao discurso do saber formal, próprio dos cientistas, dos historiadores, das classes não populares, dos adultos. Essa postura - observada especialmente em "Evocação do Recife" e "Infância" - dialoga em conformidade com uma boa parte dos discursos modernistas. 
A abertura à prosa retira esses quatro textos do centramento habitual da poesia para aproximá-los do discurso da vida. Em Entre a prosa e a poesia: Bakhtin e o formalismo russo (2003), Cristovão Tezza busca rastrear na obra de Bakhtin sua concepção de poesia, elaborada em oposição à da prosa, no discurso literário ${ }^{52}$. Tezza mostra que, para o pensador russo, prosa e poesia são duas manifestações estilísticas que se distinguem pela maneira como se relacionam com a dialogicidade interna. As palavras já carregam em si um peso axiológico, vindo de outros usos. O prosador, ao empregá-las, posicionase em relação a essa axiologia que elas carregam, criando uma duplicidade. Já o poeta tende a abafar essas outras vozes presentes na palavra, utilizando a linguagem de forma a distanciar-se do uso prosaico.

Didatização: na poesia, que espaço, que autonomia têm as vozes plurilíngües que ressoam no objeto, com relação à voz do poeta? Para Bakhtin, elas não têm presença autônoma - elas se convencionalizam, esvaziam-se, em nome do reinado da voz poética que se dirige ao objeto. Já na prosa romanesca, a dialogicidade interna terá uma presença absoluta, viva e autônoma (TEZZA, 2003, p. 266-267).

Segundo Tezza, na concepção de Bakhtin, o discurso poético se funda sobre uma visão hegemônica de mundo, uma vez que apaga as marcas deixadas na linguagem de sua passagem por outros contextos não poéticos. A linguagem literária poética tenderia, então, a criar uma nova linguagem, ao invés de explorar os dialetos sociais. O processo de centralização próprio desse tipo de linguagem faz com que o poeta não se separe da palavra que pronuncia e, assim, ela se apresenta como algo de que não se pode duvidar: "Ao se poetizar, mesmo fragmentariamente em meio à prosa, a palavra deixa momentaneamente de ser objeto de desconfiança (a essência da prosa artística)" (2003, p. 280).

O autor, no entanto, faz questão de enfatizar que a fronteira que Bakhtin estabelece entre a prosa e a poesia não é fixa, mas histórica, e que se mostra especialmente fluida nos períodos de mudanças das linguagens literárias

\footnotetext{
52 Utilizaremos algumas das concepções de Bakhtin a respeito da prosa e da poesia, na medida em que auxiliam na compreensão do contrato de veridicção da poesia autobiográfica de Bandeira e permitem certas generalizações, sem, no entanto, assumirmos inteiramente sua concepção daquilo que é estético ou literário.
} 
poéticas, como foi o caso do modernismo brasileiro, que efetuou uma "prosificação" da poesia, descentralizando a palavra poética:

A busca de um "falar brasileiro", por exemplo, foi também um "passar a palavra" a outras vozes sociais, dando-lhes um bom grau de autonomia, dando-Ihes uma forte "licença prosaica", abrindo aqui e ali a guarda do isolamento poético. Um isolamento poético que, entretanto, tende a se manter em última instância, à medida que as marcas "prosaicas" percam o seu poder descentralizador e se convencionalizem, mais dóceis, na intencionalidade centralizante da voz poética (TEZZA, 2003, p. 273).

Com isso, Tezza não quer mostrar que no modernismo não houve "prosificação", mas apenas que ela encontrou os seus limites, pois, se fosse realizada em sua totalidade, a poesia passaria a ser prosa. $O$ autor aponta Manuel Bandeira como um caso limítrofe. De fato, ao retomarmos os poemas autobiográficos analisados neste capítulo, encontramos inúmeros aspectos dessa "prosificação". Nesse sentido, "Evocação do Recife" parece ser o mais prosaico entre os quatro poemas. Ele, mais do que os outros, incorpora linguagens da vida cotidiana, o que significa, nos termos de Bakhtin, dar voz à voz alheia (não necessariamente por meio do discurso direto). O modo de falar típico de certos grupos sociais é localizável no poema. Há algumas expressões mais reificadas que permitem situar sua origem na linguagem cotidiana, como em "os caboclos destemidos" ou em "xale vistoso de pano da Costa", como vimos. Os bordões próprios das festas populares, das brincadeiras de rua e do comércio de rua são recuperados: "Fogo em Santo Antônio!", "Coelho sai!/ Não sai!", "Ovos frescos e baratos/ Dez ovos por uma pataca", "Roseira dá-me uma rosa/ Craveiro dá-me um botão". O modo de falar infantil, como já observamos, também se soma a esse coro (“Uma pessoa grande dizia”), e em alguns momentos é possível diferenciar essa voz do coro da voz do narrador.

Os versos longos, em disparidade métrica com outros, a entonação que imita a fala e certa organização narrativa reforçam o aspecto prosaico do poema. Alguns desses elementos podem ser localizados também em "Profundamente", "Infância" e "Recife", mas em menor escala. Sobre este último poema, é necessário destacar que ele traz ainda outra componente da prosa, que diz respeito às alusões intertextuais a textos literários, bem como às 
articulações interdiscursivas evidenciadas em relação aos artigos de jornal que tratavam do episódio do busto. $\mathrm{Na}$ alusão intertextual, citam-se sintagmas de outros textos. Na evidenciação interdiscursiva, dá-se resposta ao outro, exacerbando a polêmica. Desse modo, é dado espaço para eventos que se ancoram num aqui e agora. Além disso, cria-se de modo peculiar a ilusão de referente externo, dada principalmente pelo topônimo "Arrais", ilusão esta que, como já foi dito, aparece de maneira bastante diluída.

Entretanto, não se pode dizer que os poemas e mesmo "Evocação do Recife" ultrapassem a fronteira que separa prosa e poesia. Os recursos gráficos, como nos versos "De repente/ nos longes da noite/ um sino" ou em "Novenas/ Cavalhadas", a quebra de linha e a própria organização em versos são alguns dos elementos que retiram a linguagem de seu uso prosaico. Somam-se a eles os paralelismos (por exemplo em "Não Veneza americana/ Não a Mauritsstad dos armadores das Índias Ocidentais/ Não o Recife dos Mascates") e as repetições, como a do advérbio que é título do poema "Profundamente" e ecoa ao longo de seus versos, ou de "Capiberibe/ Capibaribe" ("Evocação do Recife"), ou ainda do nome "Recife" que encerra cada uma das estrofes do poema homônimo. Embora tragam para a poesia algo da oralidade, tais recursos também criam um efeito "ritualístico" próprio da palavra poética. Podemos ainda mencionar as aliterações (o / $/ \mathrm{r} / \mathrm{em}$ "Eras um Recife sem arranha-céus, sem comunistas,/ Sem Arrais, e com arroz,/ Muito arroz") e as assonâncias (o /o/ em "Barro boi morto árvores destroços redemoinho sumiu"), que chamam a atenção para o plano da expressão, criando efeitos estranhos à fala prosaica. $O$ uso da segunda pessoa do singular, nada popular, em "Recife" também afasta seus versos da linguagem do cotidiano. Logo, os poemas de Bandeira contêm elementos que produzem o isolamento próprio da poesia, tal como entende Bakhtin.

Para concluir, podemos depreender como um dos traços autorais de Bandeira uma percepção de mundo centrada na aceleração e na tonicidade maximizadas. Manuel Bandeira constrói, então, a veridicção em autobiografia com traços literários e não utilitários; com traços mais poéticos e menos prosaicos, embora os incorpore também; com traços autorais, como é próprio da esfera de circulação literária. Conforme mostra Discini, retomando Greimas (1983): 
É diferente o que acontece para a verdade a ser colhida de um poema. Aqui retornamos ao pensamento de Greimas (Idem, p.107 - 108), quando o autor se refere a uma "voz segunda, outra, que transcende a palavra cotidiana e assume o discurso da verdade". Ao referir-se a certas manifestações do poético, ele afirma: "A exploração da materialidade do significante para destacar a verdade do significado será um dos modos da conotação veridictória". Acrescentamos que, no âmbito literário, a conotação veridictória, dada segundo parâmetros da imprevisibilidade, firma um mundo interiormente inacabado (2009, p. 23).

É possível afirmar que os poemas de Bandeira, como objeto estético que são, apreendem o enunciatário, tal qual a memória apreende o narrador quando emerge no presente da narração. O enunciatário é, assim, convocado a partilhar um universo que não tem seu efeito de realidade construído, predominantemente, a partir de uma ilusão de referente externo. Afinal, esses não são textos que propõem seu contrato de veridicção a partir da necessidade de comprovovação da realidade, entendida como extradiscursiva; não é isso que interessa neles, mas a própria experiência estésica e estética que proporcionam ao enunciatário. Se compararmos o discurso literário com 0 jornalístico, percebemos as diferenças: "o discurso jornalístico confirma-se como negação do evento estético, inacabado e fraturado por excelência" (DISCINI, 2009, p. 20). Discini, entretanto, aponta para a importância de não se estabelecer uma oposição brusca entre o que seria o discurso da vida e o discurso da arte:

Vale romper a dicotomia fictício/real. Isso feito, podemos pensar numa escala linear em que, numa ponta, está a veridicção articulada ao grau máximo da força de incidência do escopo ou fiador pragmático; na outra, a veridicção articulada ao grau mínimo dessa força. Aqui se aloja a veridicção na sua variante tipológica, a verossimilhança (cf. Greimas, 2008, p. 488). Lá, o "discurso da vida"; cá, o "discurso da arte". Entre as extremidades e com oscilação possível mais para uma e menos para outra, estão ancorados os gêneros discursivos. Aqueles de fronteira circulam em mais de uma esfera de comunicação (2009, p. 22).

Tais observações ganham especial interesse quando trabalhamos com os gêneros autobiográficos, que dificilmente podem ser encaixados em um dos dois extremos. No caso da poesia autobiográfica, propomos como hipótese a tendência à construção peculiar de um referente interno para a produção do 
efeito de realidade. A memória do passado não é recriada na poesia como em diversas obras autobiográficas em prosa, em que o narrador apresenta detalhes minuciosos a respeito das pessoas, dos lugares e das datas que fizeram parte de seu passado. Também não há na poesia a preocupação em indicar a existência de documentos que comprovem o que está sendo dito. Todos esses recursos mencionados contribuem, geralmente, para a criação de uma verdade própria, que impregna o efeito de realidade. No entanto, a ausência deles não significa, como foi mostrado, que tal efeito não seja produzido, o que parece é que na poesia autobiográfica, em especial, ele é de outra ordem. A realidade que importa é, principalmente, a da memória, entendida, nos poemas em pauta, como experiência afetiva e sensorial, e não tanto inteligível.

$\mathrm{Na}$ poesia autobiográfica, a memória tende a aproximar-se do acontecimento. A vida do passado, os hábitos, as brincadeiras, as festas, o modo de falar são trazidos aos poemas de Bandeira, na medida em que afetam o sujeito no presente por já o terem marcado no passado. Assim, a adesão do enunciatário à poesia autobiográfica passa essencialmente pelo sensível. $\mathrm{O}$ enunciatário é convocado a compartilhar as experiências de um mundo organizado a partir da afetividade, o que talvez sirva de justificativa para o fato de o passado, abordado em Bandeira, ser aquele da infância ${ }^{53}$.

Dos quatro poemas, o que parece mais se diferenciar no que diz respeito a essa construção peculiar do referente interno é "Recife". Como mostram Greimas e Courtés:

Todo discurso (não apenas o literário, mas também o discurso jurídico ou científico, por exemplo) constrói seu próprio referente interno e se oferece assim um nível discursivo referencial que serve de suporte para outros níveis discursivos que desenvolve (2008, p. 415).

Em "Recife", o referente não é apenas o universo da infância mostrado por seus aspectos sensíveis, há também a presença de figuras que, por meio

\footnotetext{
${ }^{53}$ É importante enfatizar que a escolha pela dominância do sensível e as diferentes formas de figurativizá-lo exprimem também um lugar social. Não se trata, então, de opor social a sensível. Em Bandeira, fica confirmada, por exemplo, a construção de um modo de ser "popular", visto como mais espontâneo e que é euforizado.
} 
de diversas relações interdiscursivas e alusões intertextuais, recompõem no poema certa realidade histórica da época em que foi escrito. Essa realidade deve, entretanto, ser buscada em detalhes mínimos, como no antropônimo "Arrais" ou na menção do "busto" que não terá serventia depois da morte de Bandeira. $O$ referente parece alargar-se um pouco em relação aos outros textos, já que vai além do universo de vivências particulares do narrador para dar conta de fatos que seriam de conhecimento geral, criando um simulacro de referente externo, função inerente à ancoragem. É importante, no entanto, notar que, mesmo em "Recife", a construção do referente externo não é tão explícita, parece que o narrador deseja afastá-la, ao recusar a cidade do presente (tempo em que se ancora o episódio do busto e no qual Arraes é o governador), para acolher a cidade do passado.

É preciso ainda justificar a presença dos quatro poemas de Bandeira neste trabalho, mostrando o que possibilita compará-los às obras autobiográficas em prosa. Retomando algumas das características que consideramos centrais da autobiografia literária em prosa (apresentadas no primeiro capítulo), verificamos que muitas delas se mantêm presentes nos poemas em questão. Também nos poemas confirmamos como temática a recriação do passado por meio da narrativa das memórias e ainda o peso da relação que o enunciador estabelece com o passado para a configuração do éthos. Além disso, reconhecemos neles a criação do efeito de identidade entre protagonista, narrador e enunciador, ainda que ela seja mais frágil do que em muitas autobiografias em prosa e que resulte do emprego de outros recursos, especialmente no que diz respeito à produção da identificação entre o protagonista e o enunciador, dada na poesia de Bandeira sobretudo pelo que chamamos de "motivos" da memória. Como foi visto, apesar do alto grau de densidade semântica, a forma como são concretizados os tempos, os espaços e as pessoas não favorece a criação do efeito de realidade externa.

Como na prosa autobiográfica, temos em Bandeira, quanto ao tempo, a alternância entre o sistema enuncivo pretérito (para recriação do passado) com enorme ocorrência do imperfeito - e o sistema enunciativo (para apresentação do presente da narração), com predomínio do primeiro. É interessante notar que também nos quatro poemas é recorrente o uso de embreagens que presentificam o passado. Algo que parece peculiar à poesia, 
com relação à sintaxe do tempo, é o grande emprego de frases nominais. Isso se observa especialmente em "Evocação do Recife" e "Infância" e é menos recorrente na prosa autobiográfica analisada. O sistema enuncivo futuro pode ser encontrado na poesia, mas em poucos momentos como em "Recife": "Depois de morto não me interessará senão, se possível".

Com relação à organização cronológica do texto, ela pode ser verificada, ainda que não esteja tão explícita, também em "Evocação do Recife" e em "Infância", que são os dois poemas mais narrativos - quanto ao tipo textual predominante - entre os quatro analisados. De uma maneira geral, os quatro textos, se comparados à prosa, dão espaço a um número muito maior de rupturas dessa organização que produz o simulacro de cronologia e trabalham bastante com a criação de uma ordem ditada pela memória. Desse modo, algumas cenas aparecem justapostas sem que haja necessariamente uma relação de sucessão entre elas. Isso se verifica, com maior ênfase, em "Profundamente" e "Recife".

Traçaremos uma comparação mais aprofundada entre a poesia e a prosa autobiográfica no último capítulo da tese. Mas, a partir desta primeira aproximação, podemos afirmar que, embora "Profundamente", "Evocação do Recife", "Infância" e "Recife" possam ser considerados poemas de caráter autobiográfico, não podemos tratá-los da mesma maneira que uma obra autobiográfica em prosa. Afinal, a poesia possui a sua singularidade e um modo próprio de "ser autobiografia". 
CAPÍtULO 3

\section{MEMORIAL ACADÊMICO:}

\section{A IMAGEM DO}

\section{PROFESSOR-PESQUISADOR}

L'histoire de ma vie n'existe pas. Ça n'existe pas. Il n'y a jamais de centre. Pas de chemin, pas de ligne. Il y a de vastes endroits où l'on fait croire qu'il y avait quelqu'un, ce n'est pas vrai Il n'y a avait personne.

Marguerite Duras

L'amant
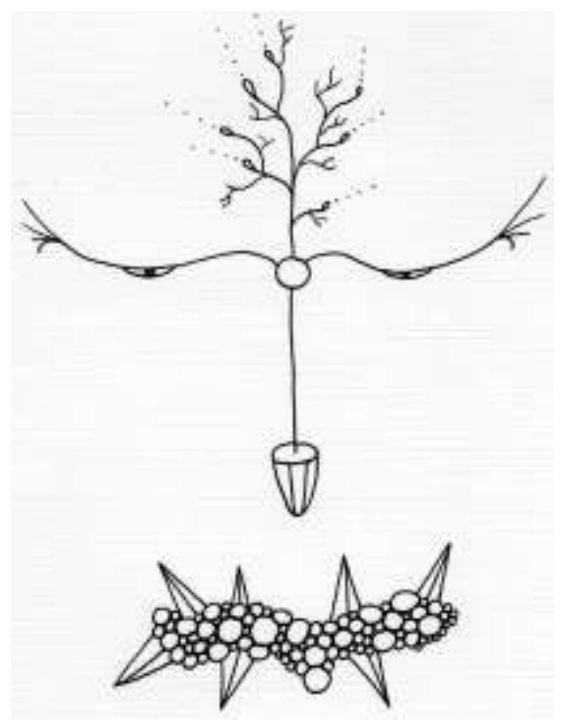
Para falar do memorial acadêmico, lancemos primeiro o olhar sobre 0 texto de Rodolfo llari, produzido por ocasião do concurso para o cargo de Professor Titular, em 1996, junto à Universidade de Campinas.

Com um prego enferrujado ou um graveto de castanheira, traçávamos um círculo no chão da praça, que já havia sido estrebaria do castelo e garagem de blindados dos dois exércitos de ocupação. Colocávamos no centro nossas figurinhas, representando animais, soldados em uniforme, futebolistas ou ciclistas famosos.

O jogo consistia em tirar as figurinhas do círculo, e cada um tinha a sua ferramenta própria: uma pedra chata, uma chapa de metal ou um caco de telha alisado interminavelmente nos dias de chuva.

Alguns meninos eram admiravelmente hábeis em acertar o monte de figurinhas, carregando-o inteiro para fora da risca no primeiro arremesso da malha: mas o vento que soprava dos "brik" era mais hábil que todos nós, e às vezes carregava as figurinhas para os quatro cantos do terreno baldio. ĺamos encontrá-las depois, sem saber a quem pertenciam, desbotadas e empastadas de terra.

Por alguma razão misteriosa, lembro-me daquela praça e daquele vento toda vez que penso na precariedade de minha memória. Minhas figurinhas estão perdidas por todos os cantos, e misturaram-se para sempre com as de tantos companheiros que vieram traçar círculos no mesmo terreno baldio: sofreram com o vento, o sol e a chuva e todo o cuidado em espanar a terra que as cobre não Ihes devolve o antigo colorido.

O fato é que lutei sempre com uma dificuldade enorme para lembrar o que quer que seja, e tenho convivido desde criança com a sensação de que tudo aquilo que sei precisa sempre ser retomado da capo. Para quem começa a escrever um "memorial", é uma sensação trágica, que não chega a ser compensada por outra - a de que apenas as emoções ficaram: se isso é verdade, contar é reviver: nada de res gestae, apenas o rem gerere dos ruminantes (p. 1-2).

O "drama do desmemoriado" começa quando o professor-pesquisador, por meio da escritura de sua vida, deve assumir um novo papel: o de narrador e, ainda, o de narrador de suas memórias. O memorial acadêmico possui como temática a recriação do percurso intelectual e profissional daquele que escreve, assemelhando-se a uma autobiografia intelectual.

Raramente publicado, é redigido numa situação de concurso, o que the impõe uma finalidade própria: fazer com que esse percurso seja aprovado pela banca de examinadores. A arguição a respeito do que se narra é um momento de avaliação importante do concurso de ingresso como professor em uma 
universidade e de outros concursos que fazem parte da vida acadêmica, como o de efetivação docente, o de livre-docência e o de titularidade. Há, então, um enunciador que, ao relatar sua vida, busca comprovar que foi adquirindo competências suficientes para ser sancionado de forma positiva pelo enunciatário. A princípio, esse gênero, pertencente à esfera das atividades científicas e acadêmicas, parece cumprir uma função bastante utilitária e nada estética.

Soma-se à narrativa da vida, uma enorme quantidade de documentos, numerados e organizados, que servem para "atestar" o que se diz: as publicações, os cargos assumidos, as orientações de mestrado e de doutorado, as participações em bancas ou em comissões, os cursos ministrados; tudo o que foi feito deve materializar-se nas pastas que acompanham o texto. Um curriculum vitae também costuma compor o enorme arquivo.

Muitos relatos são iniciados pelo nascimento, como é comum em obras de caráter autobiográfico. É o caso do memorial acadêmico do professor e crítico literário, João Luiz Lafetá, escrito em 1980 e publicado em 1999, num livro de homenagem:

Nasci no dia 12 de março de 1946, em Montes Claros, norte de Minas. $\mathrm{Na}$ minha infância era uma cidade sertaneja, entreposto comercial e centro de vasta região agropecuária. Poucas ruas calçadas com pé-demoleque, carro de boi, carroças, cavaleiros, alguns automóveis, muita poeira-vermelha e o calor de até hoje (1999, p. 13).

Com uma linguagem que se aproxima da literária, passa pelas escolas de Montes Claros; o científico e o clássico, realizados em Belo Horizonte; a Universidade de Brasília; o mestrado feito em São Paulo na USP; os anos de docência na Unicamp; o doutorado também realizado na USP; a docência na USP; até chegar aos projetos futuros. Assim, o texto abarca do momento mais distante, o do nascimento, até o presente - ponto de encontro impossível entre o passado do narrado e o presente da narração. A organização do memorial acadêmico é, então, de inclinação cronológica e, em sua superfície textual, predomina o tipo textual narrativo, conforme veremos.

Para Luiz Tatit, músico e semioticista, o começo de tudo é o radinho de pilha que, junto com o violão, despertou um gosto ligado às profissões 
escolhidas mais tarde. Mostrar o nascimento do interesse por uma determinada área do conhecimento é outra forma de compor começos, também frequente no gênero em questão:

Dois presentes de avô, um rádio de pilha aos 10 anos e um violão aos 12, lançaram-me no mundo da canção popular e livraram-me em parte do tédio e dos temores da infância. Até então imaginava que a vida dividia-se em escola, que mais tarde desembocaria numa profissão, e futebol, que bem logo, segundo os adultos, cederia lugar a coisas mais importantes. Nada mais.

O rádio foi para mim um contato direto com o sublime. Ouvia as canções e os cantores como se fossem personagens de uma história de fascínio em que todos disputavam o papel de sedutor-mor. As paradas de sucessos, com suas indefectíveis classificações, confirmavam-me plenamente essa impressão. Nutria uma admiração imensa pelos intérpretes que arrebatavam os primeiros postos e até hoje não sei se venciam porque cantavam minhas canções preferidas ou se eu que acabava preferindo as canções vitoriosas. De todo modo, estava ali, dentro do rádio, um mistério que por essa época me bastava conservar. O desejo de decifrar viria bem depois (TATIT, 2002, p. 1).

Não é apenas a maneira de iniciar o texto que varia, o memorial é gênero que possui também outras flexibilidades. Pode iluminar momentos diversos da vida do candidato, dando mais ênfase à formação, à pesquisa ou à docência. A infância pode ganhar seu lugar ou não. A vida privada pode ser mais revelada ou mantida nas entrelinhas. A história - da instituição, da ciência, do país - pode ser mais explicitada ou menos, fazendo com que o texto se aproxime algumas vezes do romance autobiográfico, outras dos relatos históricos, entre outros. Para diversos professores do período em análise, a ditadura aparece como momento incontornável:

Lembro-me nitidamente daquela manhã em que assisti, estarrecido como tantos, à verdadeira batalha que se travou na rua Maria Antônia e de que resultou, entre tantas perdas, a destruição do prédio de nossa Faculdade. Foi a segunda escola que vi queimar. Mas desta não posso me esquecer: aquela cara negra e absurda que vi, ao passar com João Marschner, noite adentro, na rua Maria Antônia (ARRIGUCCI JR., 1990, p. 12).

É a partir do presente que o narrador conta e observa sua trajetória passada. Assim, como no discurso autobiográfico em geral, encontramos 
geralmente nos memoriais um sujeito que relata a sua vida intelectual e acadêmica, cindindo-se em dois "eus": aquele que narra, o narrador, e aquele sobre quem se narra, a personagem ou, nos termos da semiótica, o ator do narrado. A relação de identificação entre sujeito que narra e sujeito do narrado, garantida geralmente pelo emprego do pronome pessoal da $1^{\underline{a}}$ pessoa do singular, é colocada em tensão pelo intervalo temporal que se estabelece entre eles: o ator do enunciado vive no tempo passado, do narrado - apresentado pelo sistema enuncivo pretérito -; o narrador, no tempo presente, da narração - apresentado pelo sistema enunciativo ${ }^{54}$. Essa distância permite ao narrador questionar-se a respeito de qual passado recriar:

O fazer um memorial pode ser comparado à montagem de um álbum de fotografias. Como as diversas fotos, cada documento relacionado é o registro de um momento. No entanto, se para os leitores a que um memorial se destina, os títulos e as atividades arroladas delineiam a trajetória intelectual e profissional de um docente e pesquisador, para o autor, eles representam experiências vividas que, graças à montagem do álbum, podem ser relembradas, revividas e analisadas.

Sendo assim, para seu autor, a tarefa de fazer o memorial envolve mais do que selecionar e ordenar documentos. Vejo a minha tarefa não só como a da pessoa que mostra seu álbum e, ao explicitar o contexto da foto, reconstrói a história do momento paralisado, imprimindo-lhe dinamicidade, mas também como a do historiador que busca a explicação das motivações e a explicação do desenrolar dos fatos relatados (NEGRÃO, 1994, p. 4).

Se podemos aproximar o memorial de uma autobiografia intelectual, não é apenas porque nele são relatados os fatos da vida acadêmica, mas porque, além disso, o memorialista geralmente discute teorias, propostas de ensino, metodologias de pesquisa, entre outros temas. O memorialista mostra o desenvolvimento de suas ideias, as mudanças em seu modo de entender as diferentes teorias ou a pesquisa, enfim, as transformações de seu ponto de vista a respeito de tudo aquilo que envolve o trabalho intelectual. A reflexão é, então, apreendida como percurso, pois vista em seu movimento ao longo do tempo. No memorial apresentado para o concurso de professor Titular de

${ }^{54}$ É preciso dizer que não é em todos os memoriais que o narrador se utiliza da primeira pessoa do singular para se referir a si mesmo no passado. Discutiremos essa questão mais adiante. 
Teoria Literária e Literatura Comparada no Departamento de Linguística e Línguas Orientais da FFLCH-USP, o professor Antonio Candido discute a atitude adotada frente aos estudos literários:

O esforço básico tem sido, desde que as posições teóricas e a prática adquiriram certa maturidade, reconhecer três momentos válidos na atividade crítica: enfoque do texto em sua autonomia relativa; consideração dos elementos de personalidade e sociedade; tentativa de estudar estes, não como enquadramento ou causa, mas como constituintes da estrutura $(1974$, p. 3).

A partir dessas primeiras observações bastante gerais a respeito dos memoriais, podemos traçar alguns pontos pertinentes para a análise de tal gênero. A totalidade escolhida para este trabalho são os memoriais acadêmicos produzidos na Faculdade de Letras (FFLCH-USP) e no Instituto de Biociências (IB-USP) desde o início dos anos 70 até os dias atuais. Com isso, pretendemos abarcar uma grande variedade de textos e ainda observar algumas mudanças no gênero. Selecionamos, para compor o corpus deste capítulo, textos representativos por trazerem características que, ao longo das leituras, passamos a perceber como recorrentes e, assim, próprias ao gênero.

Iniciaremos nosso estudo fazendo uma análise da maneira como os itinerários de vida se organizam nesses textos, o que permitirá examinar com maior cuidado a postura do narrador em relação ao próprio passado e, assim, a construção da memória. Na segunda parte do capítulo, apresentaremos uma caracterização geral do memorial acadêmico e uma análise comparativa de diferentes textos que foram colocados em circulação com o nome de "memorial acadêmico". Primeiro, observaremos a estrutura composicional e a temática do gênero; apenas alguns aspectos do estilo serão abordados. Em seguida, dedicar-nos-emos propriamente ao estudo do estilo e do éthos. Nas considerações finais do capítulo, o gênero memorial acadêmico será reinserido no seu campo de produção e de divulgação: o das atividades científicas e acadêmicas.

Embora o nosso corpus abarque textos produzidos somente a partir dos anos 70 , há indícios, no entanto, de que o memorial faz parte da vida acadêmica há mais tempo do que isso. O memorial de Dr. Paulo Enéas Galvão (1936) é o exemplar mais antigo encontrado por Câmara e Passeggi (2008), 
que procuraram investigar a gênese desse gênero nas instituições brasileiras. Ele foi apresentado para o concurso à vaga de professor catedrático de "Chimica Organica e Biologica" na Faculdade de Medicina Veterinária da Universidade de São Paulo.

Em 1911 fui matriculado no Externato Sto. Ignácio, dirigido pelos padres jesuítas. Nelle, durante 7 annos fiz meus cursos primário e secundário (curso elementar, preliminar e 5 annos gymnasiaes). [...]

No Collegio Sto. Ignácio encontrei sempre excellentes e dedicados professores, entre os quaes quero destacar especialmente o padre Leonel Franca, conhecido educador, notável por seu preparo, intelligencia e virtude; á elle devo os fundamentos de mathematica, physica, chimica e historia natural. [...]

Já no curso gymnasial, senti grande atracção pela chimica e historia natural, cujo estudo resolvi proseguir. [...]

Lembro-me, e isso é por elle [professor Miguel Ozório] recordado a meúde, ter sido acolhido como "avis rara" (GALVÃO, 1936, p. 4 apud CÂMARA; PASSEGGI, 2008, p. 105-106) ${ }^{55}$.

Prevalece no memorial a debreagem enunciativa de pessoa. O narrador, explicitado por meio do emprego da primeira pessoa do singular, faz o relato da vida de outro eu, o protagonista ou o ator do narrado. Segundo as autoras que detiveram o texto em mãos, Galvão não faz menção à família ou a outras questões que dizem respeito à vida privada, dedicando-se a apresentar a "vida científica" (CÂMARA; PASSEGGI, 2008, p. 108).

As pesquisadoras também tiveram acesso a um memorial de 1946, redigido pelo Dr. Sebastião Nicolau Piratininga, por ocasião do concurso à vaga de professor catedrático de Patologia e Clínica Médica na Faculdade de Medicina Veterinária da USP. Nesse texto, o eu dá lugar ao nós, avaliado por Câmara e Passeggi como o "início de um afastamento do sujeito de sua subjetividade dentro da academia, em prol da objetividade própria das pesquisas em ciências exatas, por influência do positivismo, cujo campo já era bastante sólido nesse período" (2008, p. 108). Citamos uma passagem:

A primeira aula que ouvimos na Faculdade de Medicina e que foi de Parasitologia, professada pelo Dr. Lauro Travassos, que aliás não conhecíamos, definiu nossa orientação scientífica. Desde esse dia e

\footnotetext{
${ }^{55}$ Manteremos a ortografia tal como aparece nos memoriais.
} 
durante 3 annos consecutivos, tivemos a felicidade de trabalhar sob sua orientação e de seu chefe de laboratorio hoje Professor Cesar Pinto, no antigo Laboratorio de Parasitologia onde permanecemos diariamente por muitas horas (PIRATININGA, 1946, p. 7 apud CÂMARA; PASSEGGI, 2008, p. 109).

Observamos em outro memorial, o do Dr. Ernesto Antonio Matera (1952), apresentado para o concurso à vaga de professor catedrático de Patologia e Clínicas Cirúrgica e Obstétrica na Faculdade de Medicina Veterinária da USP, a substituição do nós pelo ele: "Em 1932, matriculou-se na Escola de Medicina Veterinária de São Paulo, diplomando-se em dezembro de 1935" (MATERA, 1952, p. 1 apud CÂMARA; PASSEGGI, 2008, p. 111). Segundo Câmara e Passeggi (2008, p. 111), esse memorial apresenta parágrafos curtos com uma espécie de lista das atividades e dos títulos obtidos durante a carreira acadêmico-profissional.

A alteração na forma de discursivizar a pessoa, somada a outras características, como uma postura menos analítica do passado, contribui para um efeito de distanciamento do sujeito recordador em relação ao vivido. As autoras se perguntam se este seria o modelo de memorial adotado no período, mas a falta de outros exemplares impossibilita qualquer resposta. A hipótese que apontam é que essa forma de escritura acadêmica talvez indique "[...] a adoção de certo pragmatismo no seio da universidade" (2008, p. 112).

Apesar das diferenças, para Câmara e Passeggi, os três textos parecem seguir a legislação de 1935 que regulamenta a produção do memorial acadêmico junto à Faculdade de Medicina Veterinária da USP. Reproduzimos a seguir alguns artigos:

Art. 104. - O candidato instruirá seu requerimento com um memorial em que fornecerá:

a) indicação pormenorizada de sua educação secundaria, precisando as datas e logares em que estudou e, si possível, menção de notas, prêmios ou outras distincções; discriminação minuciosa de seu curso superior com indicação de tempo e logar em que foi feito, a relação das notas obtidas em exames e, quando houver, exemplares ou copias authenticadas de sua these de doutoramento;

b) relatório pormenorizado de sua actividade no magistério, cadeira ou cadeiras que leccionou, instituto ou institutos a que pertenceu, comissões desempenhadas nos institutos ou fóra delles e relação dos programmas que desenvolveu, devidamente authenticados; 
c) relatório de toda sua actividade scientifica, reportando ás memórias e trabalhos de qualquer fórma divulgados que versem exclusivamente sobre assumpto da cadeira em questão;

d) relação de trabalhos scientíficos e outros que haja divulgado, não directamente relacionados com a disciplina em questão;

e) relação minuciosa de todas as funções publicas ou particulares, de exclusivo interesse profissional, que tenha exercido;

f) relação minuciosa de todos os títulos scientificos ou honoríficos que haja conseguido.

Paragrapho único - Todas essas informações serão documentadas com certidões, originaes ou reproducções authenticadas (Decreto № 7.204, de 11 de junho de 1935 apud CÂMARA; PASSEGGI, 2008, p. 101).

A quase totalidade dos conteúdos e procedimentos exigidos, em 1935, na composição do memorial pode ser encontrada nos textos escritos a partir da década de 70 na Faculdade de Letras e no Instituto de Biociências da USP.

\section{A VIDA COMO ITINERÁRIO ${ }^{56}$}

\subsection{Afeto e movimento}

Tendo em vista a finalidade do gênero memorial acadêmico, é pertinente investigar de que forma a vida é nele construída, verificando se é apresentada como o encadeamento de fatos planejados pelo sujeito ou como uma sucessão de acontecimentos inesperados e imprevistos que o abalam. A primeira hipótese é a de que os memoriais, por visarem à construção de uma imagem positiva da competência institucional do sujeito, mostram-no como aquele que desde o início sabe o que quer, conseguindo realizar o que havia planejado. Assim, a vida apresentada estaria mais de acordo com a noção de exercício, que une uma baixa intensidade a uma alta extensidade, ou seja, uma vida com afetividade minimizada ${ }^{57}$.

A vida seria regida, então, pelo pervir e não pelo sobrevir, pois o pervir confirma a validade de nossas competências, enquanto o sobrevir revela seus limites (ZILBERBERG, 2007a, p. 29). Além disso, no meio acadêmico, a

\footnotetext{
${ }^{56}$ Nesta parte da tese, trataremos apenas da obras produzidas a partir dos anos 80 na Faculdade de Letras (FFLCH-USP) e dos anos 90 no Instituto de Biociências (IB-USP).

${ }^{57}$ Retomamos aqui a concepção de que a afetividade é tratada, pela gramática tensiva, como intensidade.
} 
interferência extrema do sensível ou ainda da afetividade nas escolhas de cunho científico parece não ser algo desejável. Assim, acreditamos inicialmente que o gênero memorial apresentaria como expectativa discursiva um narrador preocupado com a validação das competências institucionais e, portanto, orientado dominantemente pelo pervir.

De fato, muitos exemplos corroboram essa primeira hipótese. No memorial de Marli Quadros Leite, a narradora revela que as decisões do ator do enunciado, ao longo de sua vida, foram sempre pautadas pela preocupação com a educação, e sua carreira acadêmica aparece como um resultado inevitável de suas ações e anseios.

Poderia iniciar minha narrativa dizendo que a opção pela educação não foi uma tomada de posição madura e adulta. Pelo relato de meus pais, e pela lembrança que tenho de alguns fatos da infância, sei que desse período foi a preferência por não deixar sem as letras as pessoas mais simples que passaram por mim. [...] Profissionalmente, então, o curso de Magistério foi o primeiro partido em favor da educação, em 1975 (2006, p. 10).

Esses fatos implicaram a minha nomeação para dirigir a maior escola da cidade, o Instituto de Educação Euclides Dantas (105), em que estudavam três mil alunos, incluindo os alunos da Escola de Aplicação, da alfabetização à 4a série. Nessa escola, pude dar continuidade ao meu ideal de educação participativa [...] (2006, p. 11).

O trabalho de educação desse nível pode parecer, agora, desconectado do rumo que tomou minha carreira, mas essa é uma falsa impressão, pois a educação é, ainda hoje, presente em minha vida [...] (2006, p. 11).

Ser competente, em memorais como esse, é saber costurar uma vida sem grandes sobressaltos, o que se revela na manutenção de certas isotopias temáticas e figurativas. O tema da educação e figuras como "sala de aula", "escola" vão perpassar todo o texto de Quadros, mostrando que seu interesse pela questão nunca diminuiu. A mesma isotopia temática é nuclear no memorial de Ursi:

Eu admirava muito meus professores e queria ser um deles no futuro. Isso era fato! (2007, p. 2). 
Uma das atividades de que mais gostei foi o desenvolvimento de roteiros de aulas e materiais didáticos que eram aplicados com os colegas da turma e discutidos durante as aulas (2007, p. 5).

Minha vontade de atuar como professora aumentava cada vez mais... (2007, p. 17).

O exercício é dominante principalmente nos momentos em que os memorialistas narram a elaboração de suas pesquisas, teses e demais trabalhos. Nesses trechos, a intensidade é realmente fraca, como se nota quando Discini mostra que a filiação a certas linhas teóricas determinou os caminhos de sua pesquisa, quando Negrão afirma que a escolha do tema de sua tese teve como causa resultados encontrados em trabalhos anteriores, ou quando Ursi mostra o mestrado como uma consequência "natural" de seu percurso. Reconhecemos nesses exemplos a lógica implicativa, própria do exercício $^{58}$. As ações são guiadas por uma intencionalidade e os sucessos profissionais confirmam a competência do sujeito:

Para responder a essas questões falei sobre estilo na tese intitulada Estilo e semiótica. Herdeira de Saussure e Hjelmslev, busquei o estilo como efeito de sentido, depreensível da relação expressão/conteúdo, debastando o texto de sua manifestação para ir ao encontro dela; herdeira de Benveniste, busquei 0 estilo na relação enunciado/enunciação (DISCINI, 2002, p. 34).

A tese de livre-docência "O português brasileiro: uma língua voltada para o discurso" pode-se dizer que representa a conclusão de uma sequência de pesquisas sobre a hipótese de que as características dos sistemas de flexão de uma língua são responsáveis por sua estrutura sentencial e pela distribuição e interpretação das formas integrantes de seu sistema anafórico (NEGRÃO, 2004, p. 50).

O Mestrado na área de Botânica, com a orientação da Dra. Estela Meria Plastino, foi uma continuação natural do processo iniciado no estágio da graduação (URSI, 2007, p. 2).

A recorrência do exercício nos memoriais se deixa apreender, geralmente, já em suas primeiras linhas, pois são muitos os textos que se

${ }^{58}$ Conforme já foi dito, o exercício funciona segundo a lógica implicativa - se $a$, então $b-$, enquanto o acontecimento, que institui o inusitado, funciona de acordo com o modo concessivo - embora $a$, no entanto $b$-, já que ele subverte a causalidade postulada pela implicação (ZILBERBERG, 2007a). 
iniciam pelo surgimento da relação com determinada área do conhecimento. $\mathrm{O}$ narrador mostra como o ator do narrado já estava modalizado por um querer desde o início de sua vida. O querer pode aparecer como "interesse", "gosto" (Arrigucci Jr., Rodrigues, Pompêo) ou, de maneira mais intensa (Quadros), como "desejo", "curiosidade", "convocação", entre outros sentimentos. Exprimese, assim, a relação, no nível narrativo, entre um sujeito e um objeto, tornado saliente entre os outros objetos semióticos, cujo valor passa a ser desejável e necessário (quando o sujeito é modalizado também pelo dever). Modalizado pelo querer e/ou pelo dever, o sujeito se lança numa busca, que vai estabelecer a direção de seu percurso.

Os anos de ginásio e colégio foram decisivos pelo rumo que dera à minha vida futura. Comecei a me interessar muito pelo estudo de línguas, sobretudo português, latim, francês e inglês, motivado em parte pelos bons professores que tive nessas matérias e pelo hábito de leitura já firmado. [...] Nesse tempo, também tomei gosto pela música e pelo cinema; principalmente, acho que ao me tornar um leitor contumaz, botei junto na cabeça a idéia, provavelmente maluca, de ser escritor, de que me envergonhava um pouco e com a qual não sei lidar até hoje (ARRIGUCCI JR., 1990a, p. 2).

Desde pequeno tive interesse pela biologia. A partir dos 12 anos mantive coleções de Coleoptera, Lepidoptera e de outros insetos (RODRIGUES, 1996, p. 7).

Desde cedo também me interessei pela ciência. Misturava inúmeras amostras de águas coloridas com papel de seda para preparar poções as mais diversas (POMPÊO, 2007, p. 4).

Pelo relato de meus pais, e pela lembrança que tenho de alguns fatos da infância, sei que desse período foi a preferência por não deixar sem as letras as pessoas mais simples que passaram por mim. Ainda consigo sentir o prazer de ter feito algumas pessoas reconhecerem o alfabeto, assinar o próprio nome e ler algumas palavras. Essa era uma tendência forte em minha vida, uma convocação da qual não poderia passar ao largo (QUADROS, 2006, p. 10).

Entretanto, em inúmeros textos do gênero, especialmente das Letras, há passagens que fogem - ainda que pontualmente - a essa noção de exercício. É o caso do fracasso de Negrão em relação à carreira escolhida, da experiência de Arrigucci de ver destruído o antigo prédio da Faculdade na rua Maria Antonia ou ainda dos rumos inesperandos que sua vida tomou, do fim 
dos "planos casamenteiros" de Discini e do término da bolsa de Matioli, antes que pudesse finalizar a dissertação. Esses são alguns dos exemplos de momentos em que andamento e tonicidade parecem intensificar-se, em menor ou maior grau. Com isso, vê-se que, nos memoriais acadêmicos, aquilo que é recebido como impacto - por ser inesperado - também tem seu lugar.

Não conseguir minha primeira opção foi um grande fracasso para mim naquele momento. Hoje, no entanto, vejo meu ingresso na segunda opção como uma das causalidades que mudaram o meu percurso (NEGRÃO, 2004, p. 8).

Lembro-me nitidamente daquela manhã em que assisti, estarrecido como tantos, à verdadeira batalha que se travou na rua Maria Antônia e de que resultou, entre tantas perdas, a destruição do prédio de nossa Faculdade (ARRIGUCCI JR., 1990, p. 12).

Quando hoje penso nessa fase da minha vida, me dou conta de que alguma coisa de fundamental aconteceu comigo então e decidiu os rumos que eu devia tomar depois, empurrando-me para a direção da literatura. [...]

O fato é que me vi, um belo dia, padecendo o vestibular na rua Maria Antônia, numa cidade cinza e amedrontadora, que eu só conhecia de passagem (ARRIGUCCI JR., 1990, p. 3).

De repente se desestabilizaram os planos casamenteiros (...) (DISCINI, 2002, p. 9).

Início de mestrado e do curso na Farmácia e Bioquímica. Bolsa do CNPq. Minha sensação na época era algo fantástica, sentia-me nas nuvens. Sendo pago para realizar meu sonho, fazer pesquisa científica, mal podia acreditar! Obviamente tentar abraçar o mundo com as mãos teve seu preço: fim da bolsa e longe do fim da dissertação (MATIOLI, 2001, p. 4).

Nessas citações, algumas características próprias do acontecimento ficam bastante evidentes: o sujeito sofre os efeitos do que ocorreu, não sendo um sujeito do agir. Em Negrão, Discini e Matioli, é mostrado o fracasso de algo que ocorre independentemente de suas vontades. Em Arrigucci, primeiro aparece o verbo de sensação "assistir (a)"; em seguida as experiências passivas: algo acontece com ele, ele é empurrado, ele padece o vestibular. Sequências como "aí conteceu o que eu não podia esperar" e "de repente" mostram a entrada de uma grandeza no campo de presença do sujeito como 
acelerada e ainda uma contração momentânea da temporalidade. O impacto sentido, ou seja, o aumento da tonicidade, pode ser percebido em expressões como "fracasso", "estarrecido" e mesmo no prolongamento dos efeitos do choque ao longo da vida: "lembro-me nitidamente daquela manhã".

Evidentemente, entre esses exemplos, há poucos em que se apresenta plenamente o que Zilberberg (2007b) chama de acontecimento. Para isso, o impacto teria de ser percebido pelo sujeito como ainda mais brutal, elevando muito o que é da ordem dos afetos, do sensível, e praticamente anulando o que é da ordem do inteligível. Nos trechos citados, a intensidade é elevada, mas raramente sua força é tanta quanto a que encontramos nos discursos autobiográficos literários, como pudemos ver em Baú de ossos (2000, p. 289290), de Pedro Nava, em passagem já citada.

Apesar das diferenças com relação às autobiografias literárias, acontecimentos também estão presentes nos memoriais acadêmicos, ainda que dados segundo um grau menor de impacto. Não possuem no gênero acadêmico a mesma tonicidade e aceleração dos que encontramos na literatura, mas tampouco se pode dizer que não haja neles intensificação daquilo que é da ordem do sensível, como se pode notar nas expressões, já citadas: "grande fracasso", "alguma coisa de fundamental", "estarrecido".

A presença desses pequenos "acontecimentos" mostra que o sujeito conseguiu superar diversos obstáculos durante sua carreira. Se a concessão é a lógica do acontecimento (ZILBERBERG, 2007b), o sujeito que o supera é ele também "concessivo". Apesar das dificuldades, ele consegue atingir seus objetivos, o que apenas reforça suas qualidades diante dos examinadores. É um sujeito que, no nível discursivo, torna-se quase heróico, mesmo que grande parte dos seus feitos não seja contada de forma grandiloquente. As dificuldades enfrentadas, causadoras de rupturas, de descontinuidades, contribuem para atribuir maior valor ao percurso profissional e confirmam as competências do sujeito, o que justifica serem figurativizadas muitas vezes como "desafios":

Estas últimas nos traziam grandes desafios, visto que muitas eram pouco conhecidas, ou mesmo desconhecidas (ANGYALOSSY, 2006, p. 2). 
Essas pequenas rupturas - como a percepção da magnitude das florestas que vem abalar as certezas de Pardini - podem ser compreendidas, no nível narrativo, como a ação do antissujeito. O sujeito vê-se obrigado a fazer alterações em seu percurso, caso pretenda continuar sua busca. É o que vemos quando Pardini, depois da "pequena expedição", direciona o seu querer para os "estágios e oportunidades na Amazônia", na tentativa de adquirir conhecimento, por meio da compreensão da floresta majestosa. Existe, então, certa relação de proporção entre os riscos assumidos e o valor das conquistas.

As memórias que guardo desta pequena expedição são de alguma forma contraditórias: por um lado, me parecia ver concretizado um sonho há muito cultivado; por outro, descobri que as florestas eram muito mais majestosas do que eu tinha sido capaz de imaginar.

A partir dessa experiência, o fascínio pelas florestas tropicais me levou a buscar estágios e oportunidades na Amazônia (PARDINI, 2007, p. 1).

Os acontecimentos, figurativizados como "desafios", quase sempre encontram algum tipo de solução. Ursi relata o susto diante da constatação de que seus alunos não sabiam o básico necessário à sua disciplina. Em seguida, ocorre a passagem do sensível ao inteligível - ao menos em termos de dominância -, quando compreende o que ocorreu e muda seu percurso para conseguir "enfrentar" o acontecimento, já agora transformado em algo palatável.

Biologia I também foi um grande desafio. A matéria abordava macromoléculas e biologia molecular para alunos do primeiro semestre. No início da disciplina, fiz uma atividade lúdica sobre características da vida e qual não foi a minha surpresa ao perceber que cerca de $80 \%$ de meus alunos (uma classe com 72 matriculado) achavam que a água era um ser vivo. Eles não diferenciavam o elemento água dos organismos nele contidos. Fiquei paralisada por alguns instantes e decidi, naquele momento, que não seria mais uma professora como muitas que deveriam ter passado na vida daqueles alunos, que estavam focadas no que era ensinado e não no que era aprendido. Passamos um mês estudando detalhadamente as características dos seres vivos, aproveitei para abordar vários processos básicos. Apenas depois dessa longa introdução, iniciei o estudo das macromoléculas (URSI, 2007, p. 19-20). 
Os desvios, os percalços encontrados ao longo do caminho não impedem, então, o sujeito de continuar sua busca. Diversos narradores encerram seu relato assumindo o papel de destinador-julgador do sujeito do narrado, figurativizado pelo ator do enunciado, e sancionam esse sujeito a partir do exame de suas peripécias: "Esse é um momento em que fazemos uma análise das experiências vividas", afirma Angyalossy. É a hora de estabelecer a verdade: o herói é reconhecido e "premiado":

Esse é um momento em que fazemos uma análise das experiências vividas. Sinto-me realizada por ter percorrido esse caminho e aprendido muito. Chegar até aqui, só foi possível com a ajuda de muitos [...]. Como escrevi anteriormente, aprendemos juntos, pois o mundo das plantas é um aprendizado contínuo - não há barreiras, não há fim (ANGYALOSSY, 2006, p. 5).

Assim, em muitos memoriais, a sanção positiva é expressa pela confirmação de que o aprendizado ocorreu. O sentimento de realização decorre disso. "Aprender" figurativiza o processo de aquisição do saber, aparentemente o valor principal buscado na maior parte dos memoriais acadêmicos pelo sujeito do narrado:

A trajetória aqui narrada atesta um processo de amadurecimento em diversos âmbitos: no da busca de conhecimento que se transforma em produção de novos conhecimentos, no de burilar a capacidade de transmissão de conhecimento adquirido e produzido para a formação de novas mentes curiosas, no de afirmação das certezas e convicções frente aos destinos acadêmicos da instituição em cujo desenvolvimento estou engajada (NEGRÃO, 2004, p. 95).

A ênfase nesse gênero recai, então, sobre os programas de competência, em que se almeja o valor modal do saber - o conhecimento, a capacidade de ensinar, etc. - e, assim, a transformação da competência do sujeito. Entretanto, destacamos uma peculiaridade: no memorial, o programa de competência, geralmente, não vai ser resolvido num programa de performance. Não se trata de adquirir o valor modal para que se possa, por fim, entrar em conjunção com um valor descritivo. O valor saber, da maneira que se apresenta nos textos analisados, tem a característica de funcionar em cascata. Os novos conhecimentos que vão sendo incorporados apenas reiteram as 
incompletudes do sujeito, deslocando a falta e o querer para novos objetos, ainda inexplorados, na tentativa de conjunção com o valor. Quanto mais se sabe, mais a curiosidade se aguça, é o que nos ensinam esses textos. Eles constroem um valor que não se esgota num objeto único, mais do que isso, que não é fixo, não podendo, então, ser apreendido em sua totalidade: "acho que nunca vou terminar esse processo", constata a narradora referindo-se ao "aprender".

Volto à angústia, porque ela nunca me abandona, e me pergunto: "o que fiz esse tempo todo, afinal?". Eu descobri, depois de refletir longamente, instigada pelo princípio "conhece-te a ti mesmo", que aprendi a aprender. E comecei a aprender... acho que nunca vou terminar esse processo. O que fiz? Nesse tempo todo eu estudei, aliás, estudo para fazer, do melhor modo que puder, o que tenho de fazer nessa nossa carreira prazerosa, mas exigente. A sensação de falta, do que está por fazer, talvez jamais seja aplacada, mas quem sabe venham pela frente novas etapas e eu possa encontrar forças para corrigir um pouco as lacunas de meu caminho... (QUADROS, 2006, p. 84).

Se o saber parece ser o valor que busca o sujeito do narrado, podemos perguntar qual seria o objeto desejado pelo narrador. Afinal, o narrador também pode ser analisado em seu fazer, que se concretiza na narração da vida passada. O texto de Quadros fornece algumas pistas ("Eu descobri, depois de refletir logamente, instigada pelo princípio 'conhece-te a ti mesmo', que aprendi a aprender"), assim como o de Ursi:

Apresentei recentemente o trabalho "Iniciação científica em Botânica: um instrumento inovador de ensino-aprendizagem no Ensino Fundamental", no $58^{\circ}$ Congresso Nacional de Botânica. Curiosamente, nesse mesmo congresso, também apresentei um trabalho sobre os genes que codificam para a ficoeritrina em Gracilaria birdae.

A procura do "caminho certo", que tanto me afligia desde o final do Mestrado, parece não fazer mais sentido. Escrever este relato me auxiliou a perceber que existem vários caminhos a serem seguidos e que, mais cedo ou mais tarde, eles acabam se cruzando... (2007, p. 26).

O memorial parece permitir que o narrador, na elaboração de seu percurso como linguagem, alcance uma das formas do saber, o autoconhecimento. A figura do "caminho" aparece muitas vezes no final dos 
textos, pois o narrador tenta delinear um "caminho" ou ainda um "caminho certo", uma direção para sua vida, e esse traçado funciona como espelho, onde ele pode se reconhecer. Apesar do fundo comum, em cada memorial, a identidade e assim o "caminho" adquirem contornos específicos, podendo ser semantizados de formas diferentes. Durante todo o texto de Ursi, a narradora revela as dúvidas que teve no passado a respeito da via a ser tomada: a educação ou a pesquisa. Nas últimas páginas, conclui que os percursos estão entrelaçados e que os dois papéis constituem sua identidade: o de professora e o de pesquisadora - o que vem ao encontro do que se espera de um professor universitário. É a multiplicidade que caracteriza essa narradora e ainda a persistência de certos interesses. Já Dahlet condensa seus descaminhos na "estrangeiridade", resgatando assim certa coerência a partir da observação daquilo que se repetiu, do que foi comum às suas experiências, do que perdurou apesar de todas as mudanças que vieram transformar sua vida.

Para mim, qual seria o fio que costura minhas três identidades?

Minha estrangeiridade: a parte mais aflorada da minha (inter) subjetividade, e que permeia todos os campos nos quais evoluo por via das línguas (DAHLET, 2004, p. 71).

Fiorin, por meio de uma série de negativas, faz um balanço de sua vida como professor-pesquisador. Inicialmente, constitui sua identidade pelo que não é, o que se mostra coerente em relação à negativa final: a citação das palavras cheias de ironia de Dom Casmurro, de Machado de Assis. No meio do parágrafo apresenta algumas qualidades de forma afirmativa: "fui operoso" e "tive a desdita de receber o dom de reconhecer onde estava a marca da inteligência". Reconhece-se na figura do "mestre-escola" e ainda como aquele comprometido com o trabalho. Trata-se de um memorial bastante marcado pelo dever, embora o querer também modalize o sujeito do narrado.

Entre a Faculdade de Penápolis e a Universidade de São Paulo, entre o então e o agora, mediaram os sucessos relatados neste memorial.

Minha vida não tem os lances audazes dos heróis, os grandes sacrifícios dos santos, as inquietações lancinantes dos gênios, a sensibilidade exacerbada dos artistas, a argúcia dos sábios, os sucessos sociais dos que "receberam as batatas". Quase toda a minha vida se passou dentro de escolas. Analisando-a, verifico que sou um 
mestre-escola. "Verdade é que, ao lado dessas faltas, coube-me a boa fortuna" de não ter que exercer trabalho rotineiro, de não ter estudado apenas em escolinhas de bairro, de não ter ficado totalmente no olvido, de não ter sentido o menosprezo dos colegas, de não ser considerado um irresponsável, de nunca deixar de ser lembrado para uma série de encargos, de não ser visto como pessoa mesquinha, desleal, interesseira, de não ser olhado como mau profissional, de não deixar de publicar coisas que tiveram boa acolhida. Enfim, não fui Mozart, estive sempre mais para Salieri: não recebi a graça da genialidade, fui operoso, mas, em compensação, tive a desdita de receber o dom de reconhecer onde estava a marca da inteligência. "Somadas umas cousas e outras, qualquer pessoa imaginará que não houve míngua nem sobra, e conseguintemente que saí (deste balanço) quite com a vida. E imaginará mal, porque ao (chegar a este ponto da sinfonia), achei-me com um pequeno saldo, que é a derradeira negativa (deste movimento de negativas): Não tive filhos, não transmiti a nenhuma criatura o legado de nossa miséria" (FIORIN, 1994, p. 131).

Se a forma de concretizar a identidade (autoconhecimento) varia, constatamos que, no geral, ela se constitui por meio da recorrência. Em meio ao turbilhão de mudanças, de eventos que podem parecer disparatados, das experiências diversas que constituem uma vida, o narrador é capaz de delinear um sentido e ainda alguma invariância: a identidade está aí. Às vezes, ele chega a formular de maneira decisiva sua busca, como vimos em Quadros; outras, a busca aparece mais diluída no texto.

Os acontecimentos desempenham ainda outro papel nos memoriais. Ao acreditarmos que os memoriais apresentariam os eventos apenas como exercício, ignoramos o fato de que os discursos relativos a esse gênero, para que cumpram sua finalidade, devem ser peculiarmente verossímeis ${ }^{59}$. Isso significa que precisam construir o simulacro da vida do acadêmico de forma a convencer de que essa vida de fato existiu, de que não se trata de pura invenção. Talvez uma vida excessivamente coesa, em que todos os eventos já estivessem predeterminados, esbarrasse nesse tipo de problema.

Assim, no que diz respeito à tensividade, uma das formas de criar o efeito de verossimilhança e o de realidade - nos quais se baseia o contrato de

\footnotetext{
${ }^{59}$ Como mostram Greimas e Courtés (2008, p. 534), a noção de verossimilhança diz respeito a mecanismos estereotipados de uma dada cultura que servem para fazer parecer verdadeiro um discurso. Trata-se de um critério veridictório que serve apenas para avaliar discursos narrativos e figurativos e que é utilizado com maior frequência para o exame de obras literárias, mas nada impede o seu emprego no estudo dos memoriais, que buscam construir uma imagem "real" do mundo, por meio da figuratividade, e nos quais predomina o tipo textual narrativo.
} 
veridicção dos memoriais acadêmicos - é estabelecer essa espécie de pulsação, que consiste em pequenos aumentos e diminuições no eixo da intensidade, que por sua vez determinam, numa relação inversa, diminuições e aumentos no eixo da extensidade. Isso fica confirmado na afirmação de Negrão:

Ao empenhar-me nesta tarefa de construção de meu memorial, fui-me dando conta do estranho jogo entre as certezas que geraram certas escolhas e a casualidade que me levou a caminhos inimaginados em minha carreira acadêmica (2004, p. 5).

A vida vivida, matéria dos gêneros autobiográficos, não pode ser recriada discursivamente como desprovida de afetividade ou como se o grau de afetividade experimentado pelo sujeito em relação aos diferentes eventos não fosse variável, caso o enunciador queira torná-la uma vida possível. Assim, se essa intensidade nunca é muito elevada nos memoriais acadêmicos, conforme já foi dito, é importante ressaltar que ela varia e que essa variação tem seus reflexos na extensidade.

\section{O caso Sírio Possenti}

Algumas obras parecem fugir a essa característica do gênero - de ser tanto menos tônico como menos acelerado - e dão a impressão inicial de constituírem-se por meio de uma sequência de rupturas. É o caso do memorial de Possenti $(1994)^{60}$. O narrador conta que nasceu numa pequena cidade em Santa Catarina, habitada por descendentes de bergamascos, e que, de certa forma, só deu continuidade aos estudos por não ter jeito com a roça. Foi um mero acaso que fez com que não cumprisse o destino comum aos outros moradores da vila. Quando estava no mestrado, uma moça, após ouvir a história de sua origem, demonstrou não entender como o rapaz havia conseguido chegar até lá: "Só o acaso permite que alguém de fora entre nos lugares previamente destinados aos predestinados" (p. 14), comenta o próprio

\footnotetext{
${ }^{60}$ Embora tenhamos optado por trabalhar apenas com os memoriais da USP, abrimos uma exceção para o texto de Sírio Possenti, da Unicamp, que possui algumas características peculiares e pertinentes à discussão das variações do afeto no memorial.
} 
narrador. Ao decidir sair do seminário, fica espantado quando o bispo o apoia e ainda sugere que vá lecionar em Caçador. $O$ tal bispo diz coisas que o "pegaram pelo pé" e ele aceita "meio pressionado pelo discurso moral e pela surpresa de ver um bispo que não falava de projetos religiosos para sua diocese, mas de projetos educacionais para uma cidade e uma região" (p. 9). Assim, nesse memorial, o ator do narrado é carregado pela vida em direção à carreira acadêmica, sendo surpreendido sempre pelos rumos inesperados que ela vai tomando. A consciência a respeito do caminho trilhado ocorre a posteriori.

No nível tensivo, há então muitos momentos de aceleração e aumento de tonicidade, que têm seus efeitos no nível discursivo. Não existe a ideia de que o simples esforço leva à ascensão social, o que corresponderia a dizer que, se qualquer pessoa se empenhasse, mesmo desprovida dos meios econômicos para isso, conseguiria melhorar suas condições socioeconômicas. Pelo contrário, o memorial de Possenti, ao mostrar a ascensão como fortuita, deixa entrever a concepção de que condições sociais, que independem dos desejos e competências de cada indivíduo, são determinantes no que diz respeito a escolhas de profissão, situação econômica e social, grau de escolaridade, acesso a certo tipo de bens culturais, etc. Com isso, fica evidente que os valores ideológicos, embora só se deixem apreender de maneira mais completa no nível discursivo, conforme mostra Fiorin (1998), já estão impregnados na organização tensiva do texto.

Nos exemplos citados a seguir, o narrador demonstra que certos encontros e desencontros direcionaram seu percurso profissional. No primeiro, fala de quando conheceu um casal que o fez traçar novos caminhos. O casal, após receber uma proposta de trabalho, resolveu mudar-se para o Rio de Janeiro, e ele foi junto. No segundo, o narrador trata da mudança de área, ocorrida durante o período da ditadura militar e a consequente descoberta das divergências políticas existentes entre ele e aquele que seria o seu orientador.

Assim, mesmo a decisão a respeito da área de conhecimento na qual iria desenvolver toda a sua pesquisa a partir daí aparece como não tão planejada. 
Conhecer Jaeme e Helena foi tão fundamental para as minhas um pouco casuais decisões futuras quanto conhecer Dom Orlando e aceitar sua proposta (POSSENTI, 1994, p. 10).

Faria certamente tese nesta área se não surgisse uma forte incompatibilidade com quem seria o óbvio orientador (POSSENTI, 1994, p. 15).

Trata-se de uma vida que, no nível do narrado, realiza-se quase sem o controle do sujeito e que parece basear-se na lógica concessiva, própria do acontecimento, e não na implicativa. Afinal, embora tenha nascido em um "povoado", chegou a ser professor da Unicamp. Entretanto, Zilberberg afirma que o modo concessivo traz em si o seu limite, ou seja, a concessão "deve se limitar a si mesma, senão criaria, a sua revelia, uma regularidade que ela vem abalar" (2007b, p. 24). Uma vez que a concessão comece a se repetir, cria-se uma espécie de lei, e o que era inesperado torna-se já esperado, afinal é sempre assim. A repetição, nesse caso, enfraquece o impacto sensível e aumenta a previsibilidade, que é da ordem do inteligível. Assim, o ator do narrado vive diversos "pequenos acontecimentos" que o abalam, mas para o sujeito da enunciação (composto de enunciador e enunciatário), que vai percebendo essa lei, o acontecimento é esvaziado de sua carga intensiva, já que se torna previsível. $\mathrm{O}$ ator do narrado é construído, nesse memorial, como aquele que está sempre fora dos padrões, que sempre foge à regra, como mostram as palavras do próprio narrador:

Sempre que estou num lugar, estou fazendo o que se faria num outro. No ginásio e no colégio só li e estudei bobagens; quando devia fazer um curso de filosofia, li literatura; quando fui estudar documentação, lecionei lógica; quando fui ser professor de lógica, estudei filosofia, literatura e lingüística (POSSENTI, 1994, p. 14).

Torna-se, então, relevante para este estudo separar o que ocorre com relação à tensividade no nível do narrado e no da narração. Como vimos no memorial de Possenti, aquilo que é acontecimento para o ator do narrado, para o narrador e mesmo para sujeito da enunciação vai perdendo sua intensidade ao repetir-se, ganhando extensidade no discurso. Logo, o narrador percebe a sequência de rupturas na vida do ator do narrado como exercício. E esse memorial, que parecia romper as coerções do gênero, termina por adequar-se 
a elas, embora também revele traços da relativa estabilidade dos gêneros de que trata Bakhtin (2006).

Desse modo, nos memoriais estudados, comprova-se que a intensidade mantém-se sempre baixa, mas não estática, uma vez que o efeito de realidade fundamenta-se, no que diz respeito ao nível tensivo, numa pequena variação de tonicidade e de andamento, que tem suas respostas também no eixo regido, o da extensidade: a espacialidade e a temporalidade se contraem e dilatam. Afinal, o memorial acadêmico, por ser um gênero autobiográfico, apresenta um simulacro da vida e seria menos verossímil caso não a encenasse como sendo feita de certa oscilação entre o exercício e o acontecimento. A variação entre essas duas grandezas faz parte, provavelmente, de um grande número de discursos, do mesmo modo que a preponderância do exercício, uma vez que o acontecimento é da ordem do extraordinário. Mas nos memoriais podemos observar uma ocorrência singular desse movimento.

Seja no meio acadêmico e científico, seja na cotidianidade das atividades humanas não institucionalizadas, a vida não será geralmente compreendida como algo completamente coeso. É o que pudemos depreender da análise do modo como a figuratividade é construída nos textos analisados e também o que aparece de maneira explícita em reflexões como a apresentada a seguir:

Mesmo assim, será que esses percursos se caracterizam por uma linha reta? Não, definitivamente. A identidade não é feita de um bloco só, e sim de uma história ainda em processo. A não ser que se entenda identidade como se fosse um momento apreendido para extraí-lo do fluxo temporal no intuito de imobilizá-lo, de fixá-lo, à semelhança da foto. Ainda assim, a linha não se apresenta reta: ela se desenha também conforme os encontros, seja com leituras seja com pessoas seja com instituições, que acabam mostrando trilhas novas (DAHLET, 2004, p. 71).

Isso fica ainda mais evidente nas palavras atribuídas ao médico José Egon Barros da Cunha: "A vida é um romance sem enredo" (NAVA, 2003, p. 
103). O médico enaltece a vida como acontecimento e não como exercício. Se os eventos fossem percebidos apenas como exercício pelo sujeito, o futuro seria mostrado como totalmente programável, o que não parece aceitável no romance autobiográfico, nem mesmo no memorial acadêmico.

Assim, nos memoriais, o contrato veridictório estabelece que a afetividade deve pulsar de modo próprio ao longo do discurso. Podemos tomar como outro exemplo as palavras de Bergson, que também expressam essa concepção de que a afetividade é dinâmica. Quando reflete sobre a natureza da duração, o filósofo opõe-se à ideia de que a mudança reside na passagem de um estado ao outro, pois para ele mudamos sem cessar: "[...] um leve esforço de atenção revelar-me-ia que não há afeto, não há representação ou volição que não se modifique a todo instante; se um estado de alma cessasse de variar, sua duração deixaria de fluir" (2006b, p. 2).

No entanto, insistimos na ideia de que parece não haver lugar para picos de tonicidade e grandes acelerações nos memoriais, uma vez que isso poderia revelar um total descontrole do sujeito com relação à sua trajetória, comprometendo a própria finalidade do gênero, que é a de convencer o enunciatário a respeito das competências acadêmicas do enunciador.

\subsection{A CIÊNCIA E A MEMÓRIA}

Nos memoriais, o sujeito do narrado olha sua vida de maneira prospectiva, em direção ao futuro, ao que é inacabado, aberto. Isso faz com que a vida não possa ser compreendida por ele apenas como exercício, para que não pareça uma vida que cumpre um programa pré-instituído, conforme já foi comentado. As dúvidas a respeito do futuro e das escolhas a serem feitas confirmam que, embora o sujeito desenvolva projetos na tentativa de controlar todas as variáveis e não ser surpreendido, ele ainda pode deparar com o acontecimento, que é a própria impossibilidade de tudo prever e a medida de sua competência.

Diferente do ocorrido por ocasião do ingresso no Mestrado, tive dúvidas sobre a área de trabalho que gostaria de desenvolver na Tese de 
Doutorado. Meu dilema era: prosseguir na Botânica ou dedicar-me a algum trabalho na área do Ensino de Ciências ou Biologia. Qual o "caminho certo" a seguir? (URSI, 2007, p. 11).

Que tipo de professora eu seria? Será que existiria correspondência entre minhas idéias e minha prática docente? Será que eu aguentaria ficar longe da USP, dos meus amigos, das pesquisas, dos cursos, das algas? Será que eu conseguiria um emprego?

Finalmente, chegará o momento de procurar respostas para todas essas questões... (URSI, 2007, p. 17-18).

Entretanto, se o sujeito do vivido tem um olhar prospectivo, não é esse o caso do narrador. O narrador observa a própria vida de maneira retrospectiva, podendo assim lançar "previsões" no texto, que não são mais do que antecipações. Em Pompêo, por meio do futuro do pretérito - tempo próprio das antecipações por descrever ações posteriores a um momento de referência pretérito (FIORIN, 1996, p. 159-160) -, o narrador mostra a importância que o encontro com Viviane teve em sua vida. Nessa passagem, fica bem evidente que a valorização dos eventos passados está ligada a seus desdobramentos futuros, já conhecidos pelo narrador. O passado é observado, hierarquizado e valorizado a partir do tempo presente.

Foi também nesse período que conheci a Viviane, que viria a ser não só minha namorada, mas esposa, mãe do meu filho, minha parceira profissional e a luz que falta na nossa vida solitária (POMPÊO, 2007, p. $5)$.

É a observação retrospectiva que permite ainda ao narrador reintegrar ao menos em seu relato - boa parte do que foi vivido como acontecimento a uma ordem causal, regida pela lógica implicativa. Essa reintegração é necessária porque o acontecimento parece ser avaliado como excessivo nos memoriais. Para a jovem, não conseguir a sua primeira opção no vestibular não era esperado, mas, quando a narradora, instaurada no presente, examina o ocorrido, pode atribuir um novo sentido à derrota. Recupera-se então, em Negrão, a relação de necessidade entre a segunda escolha - ou seja, a derrota - e o futuro profissional. É como se a narradora dissesse: "hoje sou linguista graças a esse fracasso". Com isso, ocorre até mesmo uma inversão do valor do fracasso. Dahlet busca alguma explicação para as inconstâncias que 
configuram sua identidade. Inicialmente, não encontra nenhuma "lei", mas logo reconhece a ligação entre todos os caminhos que sua vida tomou, percebe um fundo comum para o que parecia fortuito: sua "estrangeiridade".

Não conseguir minha primeira opção foi um grande fracasso para mim naquele momento. Hoje, no entanto, vejo meu ingresso na segunda opção como uma das causalidades que mudaram o meu percurso (NEGRÃO, 2004, p. 8).

Mesmo assim, será que esses percursos se caracterizam por uma linha reta? Não, definitivamente. A identidade não é feita de um bloco só, e sim de uma história ainda em processo. A não ser que se entenda identidade como se fosse um momento apreendido para extraí-lo do fluxo temporal no intuito de imobilizá-lo, de fixá-lo, à semelhança da foto. Ainda assim, a linha não se apresenta reta: ela se desenha também conforme os encontros, seja com leituras, seja com pessoas, seja com instituições, que acabam mostrando trilhas novas. Para mim, qual seria o fio que costura minhas três identidades?

Minha estrangeiridade: a parte mais aflorada da minha (inter) subjetividade, e que permeia todos os campos nos quais evoluo por via das línguas (DAHLET, 2004, p. 71).

Assim, mesmo que num primeiro momento o percurso intelectual se apresente sem orientação alguma, o narrador logo mostra que a falta de coerência e de sentido em sua vida era apenas aparente, revelando a verdade do memorial acadêmico, que é uma vida cuidadosamente planejada. Quando o fato torna-se lembrança, o narrador pode explicá-lo de maneira distanciada, encontrando sua lógica profunda, velada, o que aumenta a inteligibilidade do passado.

A visão retrospectiva do acontecimento, que busca uma lei escondida sob a aparente desordem, mostra que o narrador é mesmo um acadêmico ou um cientista competente, uma vez que ele consegue encontrar as regularidades encobertas. Ele faz bem o seu trabalho. Landowski (2005, p. 81), refletindo sobre as possibilidades de dar conta de processos em grande escala com seu modelo de regimes de interação, define a prática científica (em oposição às práticas de tipo religioso, estético e filosófico) como justamente a que busca descobrir a lei de uma regularidade. Geninasca (1997, p. 212) afirma que a unidade do mundo, para o sábio, não é mais que um objeto do pensamento, que ele constitui para si por meio de um encadeamento de 
causas e efeitos. Ele acrescenta ainda que a racionalidade científica ou a maneira como o discurso científico garante a inteligibilidade do mundo procede pelo estabelecimento de cadeias causais, de caráter metonímico, colocadas fora do campo da percepção imediata.

Normalmente, a memória autobiográfica é aquela de uma presença, mais tônica ou menos, como vimos. Quando o narrador se recorda de seu passado, ele se recorda de sua própria presença naquele período. O narrador lembra-se das emoções e das sensações já experimentadas (os aromas, as texturas, os sabores, as formas), podendo até mesmo revivê-las, o que mostra que ele esteve lá, como testemunha de um mundo que não existe mais e, principalmente, como alguém que fez parte desse mundo. Nos memoriais, entretanto, são raras as passagens em que vemos essa aproximação do narrador e do ator do narrado ser realizada por recursos que ultrapassem a debreagem de pessoa. Além disso, essas raras passagens localizam-se, principalmente, no início dos memoriais, quando a infância é retratada, e desaparecem conforme o texto avança.

Em Discini, a descrição da escola é feita por meio de uma hiperfocalização em detalhes e, principalmente, nas qualidades dos objetos - 0 branco do avental, a sensação tátil do estojo -, recriando no texto não simplesmente como o mundo era, mas como a criança o percebia. Essa hiperfocalização produz inclusive um desequilíbrio entre os objetos da escola, que parecem enormes, e a menina por cujos olhos entramos em contato com eles. Em Angialossy, as embreagens de tempo ("vejo") e de espaço ("este"), que anulam a oposição entre o sistema enuncivo e o enunciativo, são responsáveis por trazer o tempo e o espaço da infância para o aqui e o agora da enunciação, inserindo o narrador e também o sujeito da enunciação na cena lembrada. O presente pontual em "vejo" faz com que o evento narrado seja mostrado como se surgisse naquele instante diante do sujeito que revive o seu passado. Principalmente os aromas são recuperados nesse texto.

Importa o tato do estojo de madeira ou de lata, em que se guardavam lápis, caneta e sonhos; o cheiro da borracha de apagar; o avental branco com inscrição em linha azul, Q.A., Quinzinho do Amaral, uniforme a ser conservado limpo (DISCINI, 2002, p. 8). 
Nasci em uma fazenda de café e desde cedo convivi com o cheiro dos grãos de café secando no terreiro - trago este aroma em minha mente até hoje; cresci em uma serraria, tendo contato próximo com o cheiro da serragem e a visão das toras de madeira - araucária e peroba-rosa; ao vir para a cidade grande, vejo meu pai todos os dias cuidando de suas orquídeas, que eram muitas - todas protegidas em ripados de madeira, com etiquetas indicando seu nome científico; no jardim de casa havia uma planta masculina de Cycas circinalis, que sempre após as chuvas exalava seu odor característico, que sempre me fascinou. Creio que essas situações me foram marcantes e nortearam minha decisão, desde cedo, que trabalharia de alguma forma com as plantas (ANGYALOSSY, 2006, p. 1).

No entanto, é preciso insistir na ideia de que não são frequentes as vezes em que a presença sensível desse outro eu, o do passado, é recuperada nos memoriais. No geral, busca-se apagá-la, para que o outrora possa ser analisado, estudado e examinado com o devido distanciamento. Além da dominância da lógica implicativa que subjaz à análise feita pelo narrador, outros elementos também contribuem para recortar o passado. São eles o emprego recorrente de topônimos, antropônimos e cronônimos, a presença fraca de um léxico que expressa emoção, a preferência por certas formas verbais, como o pretérito perfeito, que apresenta os eventos a partir de um ponto de vista externo, em oposição ao imperfeito, entre outros elementos.

Em meados de 1993, o SENAC me convidou para fazer uma palestra em Salvador, no lançamento do livro África: moda, cultura e tradição, que reunia textos de Fábio Ávila e Fábio Leite (e algumas citações de minha tese) (219), sobre fotos do vestuário africano feitas por Maureen Bisilliat em Abijan (PETTER, 2008, p. 24).

O mundo produzido nos memoriais aparece como preexistente ao ato de lembrar e ainda de narrar. As datas, os nomes completos, os endereços apontam para um conhecimento oriundo de um discurso social partilhado. $O$ narrador apoia, então, esse seu universo naquilo que já é dado. Isso justifica bem o porquê de a memória não ser vista, nesse gênero, em ato de fazer-ser o passado, como geralmente ocorre nos textos mais literários, especialmente nos poemas analisados de Bandeira. Logo, também não são frequentes as passagens que mostram um narrador de certa forma espantado pela lembrança do que lhe ocorreu, fazendo da memória um acontecimento. 
Assim, com relação à constituição da memória, encontramos apenas alguns trechos que revelam uma diminuição da extensidade e um pequeno aumento da intensidade, como quando o narrador em Arrigucci mostra sentir dificuldade em contar tudo o que experimentou no período passado na França. Confessa-se inicialmente "perplexo", ou seja, hesitante, paralisado pela massa de histórias que invade seu campo de presença, preenchendo-o:

Como contar, ainda que sumariamente, tudo o que pude ver, ouvir e pensar, em matéria de arte, ao longo do tempo em que estive fora? Confesso-me perplexo, sem saber por onde começar. No entanto, como é preciso, vou sugerir alguma coisa (ARRIGUCCI JR., 1990a, p. 20).

Outra passagem que mostra o narrador surpreendido pela memória é o início do memorial de Matioli, especialmente o momento em que salienta que as lembranças ocorrem a ele, na forma própria do sobrevir. O efeito, ao menos nesse pequeno trecho, é de que ele as narra conforme surgem em seu presente. São recordações que carregam uma carga afetiva forte, como indica o emprego de certos diminutivos ("tatus-bolinha", "bichinhos"), possessivos ("meu" e "minha"), verbos perceptivos ("via") e ainda de alguns adjetivos e advérbios que exprimem avaliação e emoção ("alegrias", "maravilhosas", "sofregamente", "solenemente"). O narrador mostra a criança a partir de como percebia o mundo ao seu redor e mostra o passado a partir do ponto de vista da criança, ao qual o seu vem fundir-se momentaneamente. A recorrência de expressões relacionadas à memória - que instaura o narrador como aquele que se lembra de seu passado ("A primeira lembrança", "Posso ainda lembrar cristalinamente") - também é fundamental para criar a identificação entre o narrador e o menino, pois, por meio dessas expressões, produz-se o efeito de que o narrador esteve presente naquele outro período e de que é dessa sua presença que fala:

A primeira lembrança que eu posso registrar com relação ao meu interesse pela área biológica data de 1961, aos quatro anos de idade, ao acompanhar o sofrimento de minha avó Kasemira (materna) que estava com câncer terminal. Prometi solenemente a ela que torna-me-ia um médico para poder curá-la. Desde então ocorre-me uma série de outras memórias relacionadas a esse interesse. Algumas mais marcantes são os experimentos realizados com tatus-bolinha e 
formigas, sendo alguns deles de natureza sádica como ocorre naturalmente em várias crianças, mas outros de natureza lúdicocientíficas, tais como a construção de labirintos (com jogos infantis de construção que meu pai, que sempre trabalhou com construção civil, gostava de me presentear) para os pobres bichinhos que teimavam em usar as paredes para seu desvencilhamento. Muitos laboratórios químicos infantis e juvenis, além de "kits" preparados pela extinta FUNBEC foram completamente sucumbidos através tanto do acompanhamento cuidadoso dos protocolos fornecidos como da execução de experimentos de natureza aleatória, com resultados muito menos interessantes do que as fantásticas explosões ou descobertas maravilhosas desejadas. Posso ainda lembrar cristalinamente a alegria ao ganhar um microscópio, aos dez anos, quando tudo que eu via pela frente era disposto sobre poucas lâminas que acompanhavam o instrumento e que eram sofregamente observadas (MATIOLI, 2001, p. 2).

\section{DUAS MEMÓRIAS}

\subsection{Da práxis enunciativa ao gênero}

De natureza socioletal, o gênero discursivo remonta às práticas pouco a pouco sedimentadas pelo hábito das comunidades linguísticas e culturais no curso da história. Pode ser entendido, então, como um produto do uso, que se estabelece entre o sistema (langue) e a fala (parole). Sua análise parece-nos fundamental para os estudos da enunciação, pois, conforme Bertrand, não se pode compreender a enunciação individual sem levar em conta as enunciações coletivas que a antecederam e que a tornam possível, uma vez que a sedimentação das estruturas significantes, resultantes da história, determina todo ato de linguagem:

A primazia da práxis enunciativa sobre o engajamento particular na fala em ato é um primeiro dado: a enunciação, a seu modo, convoca os produtos do uso que ela atualiza no discurso. Quando os revoga, ela pode transformá-lo, dando lugar a práticas inovadoras, que criam relações semânticas novas e significações inéditas. $E$ esses enunciados, por sua vez, se forem assumidos pela práxis coletiva, poderão cair no uso, nele se sedimentando e assim se tornando convocáveis, antes de se desgastarem e serem revogados. [...] Essa dialética da práxis (sedimentação/inovação) questiona pois, prioritariamente, a espessura cultural do sentido (2003a, p. 88). 
Os gêneros vivem, então, nesse ir e vir entre a sedimentação e a inovação. É o que podemos depreender também da conhecida definição de Bakhtin, para quem o gênero é um enunciado relativamente estável (2006, p. 265). Assim, o exame desse objeto requer um olhar atento tanto para estabilidades (as invariantes) quanto para instabilidades (as variantes).

O memorial acadêmico não foi sempre o mesmo. Na década de 70 na Faculdade de Letras (USP) e nas décadas de 70 e 80 no Instituto de Biociências (USP), apresentava-se, predominantemente, quase como um currículo expandido ou um relatório de atividades, mas, a partir dos anos 80 na Faculdade de Letras e dos anos 90 no Instituto de Biociências, encontramos, no geral, textos que abarcam também a vida privada, falam da infância e das relações familiares e de amizade. O memorial se abriu inclusive à incorporação de fotos e de outras recordações, como a imagem da dedicatória de um professor que preenche uma das páginas do memorial de Ursi:

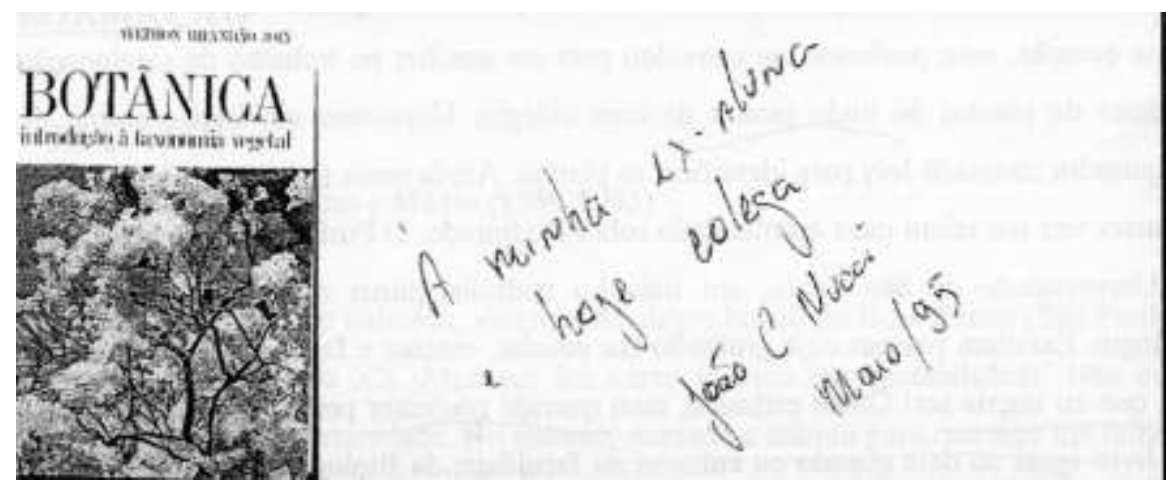

(2004, p. 4)

Vejamos o memorial do professor Antonio Candido, apresentado em 1974:

\section{- Constituição de equipe}

Contratado em dezembro de 1960 para inaugurar na Universidade de São Paulo o ensino de Teoria da Literatura, o candidato se preparou desde logo em formar uma equipe, que pudesse continuar e desenvolver as atividades da disciplina recém-criada.

O primeiro elemento recrutado, Roberto Schwarz, foi encaminhado com este intuito para os Estados Unidos no fim de 1961. Lá estudou sob a orientação de René Welleck no Departamento de Literatura Comparada 
(que engloba Teoria da Literatura) da Universidade de Yale, obtendo grau de mestre. De volta, foi nomeado Assistente no fim de 1963 ( $p$. 21).

Observa-se que, com relação à pessoa, é utilizada a embreagem enunciva da enunciação e do enunciado (o narrador é construído de maneira implícita e o ator do narrado é chamado de "candidato" ou por um "ele"), criando o efeito de objetividade, devido ao distanciamento produzido entre a instância da enunciação e o próprio enunciado. Logo, a identidade entre enunciador e narrador, assim como a identidade entre narrador e ator do narrado não se realizam pelo uso do pronome pessoal eu e de outras marcas da primeira pessoa, como é comum nas obras autobiográficas. São outros os recursos que produzem a identificação entre essas instâncias. A assinatura que normalmente encerra o memorial está entre eles:

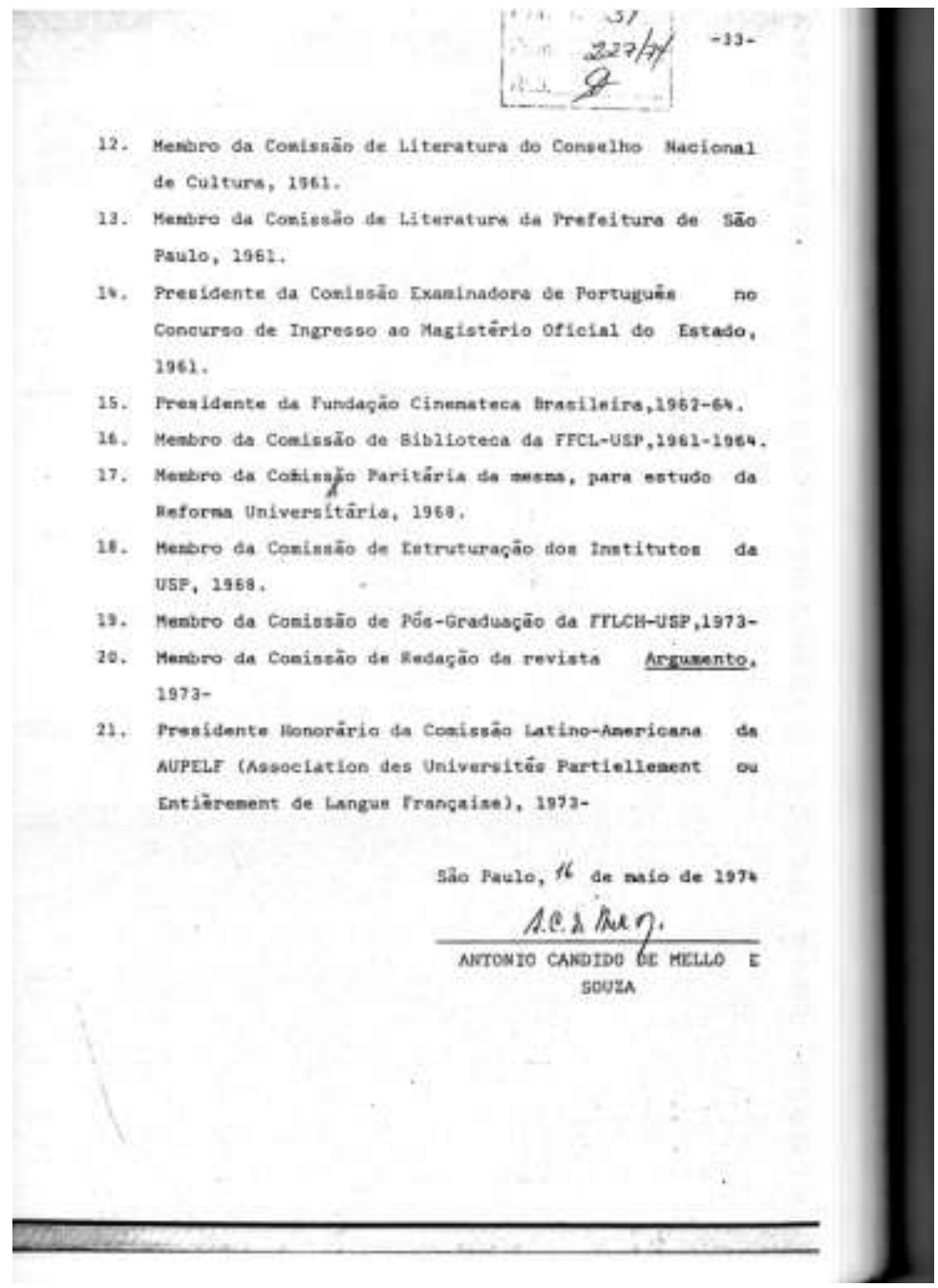

(CANDIDO, 1974, p. 33) 
A assinatura cria o efeito de explicitar no texto o enunciador, sempre implícito, pois quem "fala" é o narrador. É nesse sentido que podemos entendê-la como uma embreagem, que, conforme já mostramos, confunde os níveis do narrador e do enunciador, criando a identificação entre ambos.

A assinatura também "assegura" a sinceridade e, assim, a veracidade do que está sendo dito, pois compromete ainda mais o enunciador (e o narrador) com o relato, maximizando sua responsabilidade. Feita em letra cursiva, em oposição à letra de forma, e à caneta, em oposição ao texto datilografado, ela evoca o movimento da mão do enunciador, produzindo um efeito de presença corporal, como se, por meio dela, o enunciador declarasse que está ou esteve ali. Isso reforça o seu comprometimento. A assinatura cria ainda o efeito de realidade por sua alta força icônica. Ela é acompanhada da data, que, além de localizar temporalmente a escritura do texto, contribui também para aumentar sua veracidade, já que permite inserir a enunciação no tempo social e, assim, partilhado por enunciador e enunciatário. Além disso, o próprio título da obra - "Memorial acadêmico" ou "Memorial" - também garante a identificação entre as duas instâncias mencionadas. O leitor que depara com "Memorial acadêmico" tem como expectativa que narrador e enunciador sejam idênticos, mesmo que isso não se manifeste nas formas pronominais. Pelo mesmo motivo, o título cria ainda o efeito de identidade entre o protagonista e o narrador, reforçado pelo relato da produção por parte do protagonista das inúmeras obras assinadas pelo "enunciador". Assim, o trajeto do ator do enunciado passa a corresponder àquele do ator da enunciação.

Durante esse estágio, dedicou-se ao estudo de Sistemática de Drosophila, tendo sido co-autor da descrição de duas espécies novas dessa mosca: Drosophila neoelliptica species nova C. Pavan e L. E. de Magalhães - publicados nas páginas 16 e 19 de:

1. PAVAN, C., 1959

"Espécies Brasileiras de Drosophila II",Boletins da Faculdade de Filosofia, Ciências e Letras da Universidade de São Paulo CXI. Biologia Geral no. 8, 1959, 37 págs. (MAGALHÃES, 1978, p. 3).

Lejeune, comentando o emprego da $3^{\underline{a}}$ pessoa na autobiografia para se referir a si mesmo no passado, aponta alguns efeitos possíveis que convergem para certa transcendência da própria subjetividade: 
Esse procedimento pode ter sido empregado por razões muito diversas, e conduzir a efeitos diferentes. Falar de si na terceira pessoa pode implicar ou um imenso orgulho (é o caso dos Comentários de César, ou de tais textos do general de Gaulle) ou uma certa forma de humildade (é o caso de certas autobiografias religiosas antigas, em que o autobiógrafo chamava a si mesmo "o servidor de Deus"). Nos dois casos o narrador assume em relação à personagem que ele foi ou a distância do olhar da história, ou aquela do olhar de Deus, ou seja, da eternidade, e introduz na sua narrativa uma transcendência à qual, em última instância, ele se identifica (1996, p. 16; tradução nossa) ${ }^{61}$.

Se, no caso de diversas autobiografias religiosas - como as Confissões (2010), de Santo Agostinho -, esse mecanismo introduz uma transcendência, permitindo ao narrador colocar-se no mesmo ponto de observação em que está Deus, no caso dos memoriais, é ao ponto de vista da ciência e da comunidade acadêmica que vem identificar-se o narrador e assim também o enunciador. A ciência e a comunidade acadêmica nos memoriais ocupam, então, um lugar com certas afinidades àquele destinado a Deus nas autobiografias religiosas, estabelecendo, ao menos como efeito, esse ponto transcendente de observação da vida, o lugar do grande destinador. Assim, o narrador - logo também o enunciador - relata sua trajetória de vida a partir de um ponto de vista que parece exterior.

Dessa forma, cria-se a ilusão de que tal trajetória narra a si mesma: é como se não houvesse um sujeito discursivo por trás dos fatos. O efeito é de objetividade, mas não de qualquer objetividade. Temos uma objetividade afim com aquela conferida pelo discurso acadêmico. Esse efeito é reforçado pela espacialidade e temporalidade enuncivas, tanto do enunciado quanto da enunciação. Características semelhantes às depreendidas do texto de Luiz Edmundo de Magalhães encontramos nos memoriais produzidos até o início dos anos 80 na Faculdade de Letras (FFLCH-USP) e dos anos 90 no Instituto

\footnotetext{
61 "Ce procedé a pu être employé pour des raisons très diverses, et aboutir à des effets différents. Parler de soi à la troisième personne peut impliquer soit un immense orgueil (c'est le cas des Commentaires de César, ou de tels textes du général de Gaulle), soit une certaine forme d'humilité (c'est le cas de certaines autobiographies religieuses anciennes, où l'autobiographe se nommait lui-même "le serviteur de Dieu"). Dans les deux cas le narrateur assume vis-à-vis du personnage qu'il a été soit la distance du regard de l'histoire, soit celle du regard de Dieu, c'est-à-dire de l'éternité, et introduit dans son récit une transcendance à laquelle, en dernier ressort, il s'identifie".
} 
de Biociências da USP, como vemos no texto de Moreira, especialmente preciso quanto às datas:

1960 e 1961 - colaborou na organização e realização das I e II Reunião Nacional de Técnicos trabalhando em pesquisas de pesca, realizada em Santos, patrocinada pelo CNPq e apoiada pela Com. Est. de Pesca. 1962 - participou da III reunião Nacional de Ténicos trabalhando em pesquisas de pesca, realizada em Florianópolis, Santa Catarina (MOREIRA, 1971, p. 8).

Este esforço se esboça na tese de concurso (1945), que escolheu assunto teórico e procurou superar certo pragmatismo sociológico inicial, por meio de pontos de vista críticos de T. S. Eliot. Mais recentemente, o livro Literatura e sociedade (1965) apresenta formulações de maior esforço integrativo (CANDIDO, 1974, p. 3).

O sumário do memorial de Moreira apresenta as seguintes atividades: 1. Filiação, 2. Formação escolar, 3. Títulos universitários, 4. Cursos de Aperfeiçoamento e Extensão universitários, 5. Bolsas e Auxílios obtidos, 6. Atividades profissionais \& Atividades didáticas, 8. Orientação de teses, 9. Participação em bancas examinadoras, 10. Participação em cruzeiros oceanográficos, 11. Participação em Congressos e Reuniões científicas, 12. Trabalhos apresentados em Congressos e Trabalhos publicados - todas organizadas cronologicamente em forma de lista. No geral, encontramos nos memoriais uma progressão temporal que imita a passagem "natural" ou "real" do tempo. Conforme já foi comentado, são relatados dos eventos mais antigos aos mais contemporâneos ao ato de narrar. O tempo verbal de maior emprego é o pretérito perfeito, que, com aspectualidade pontual, exprime o dinamismo próprio aos textos de tipo narrativo. É o que verificamos em Magalhães e nos demais memoriais da época:

Iniciou o Curso Ginasial em 1939, no Ginásio Diocesano São Luiz Gonzaga, em Guaxupé, Estado de Minas Gerais, onde fez o 1‥ Ginasial. Em 1940 transferiu-se para o Ginásio Paulistano, em São Paulo, onde completou o Curso Ginasial em 1942 (1978, p. 7).

Logo, prevalece nos memoriais acadêmicos a narração, pois eles concretizam atores, tempos e espaços figurativamente e relatam 
transformações de estado, sendo marcados pela noção de progressão temporal (FIORIN, 2005a). É pertinente observar que nesses memoriais mais antigos nem sempre há espaço para refletir sobre o vivido; encontramos pouca interferência do tipo de texto opinativo ou expositivo. Magalhães (1978), por exemplo, afirma que, a partir de um dado momento, mudou sua linha de pesquisa, mas não ficamos sabendo as razões que o levaram a isso, se essa foi uma mudança benéfica, como se sentiu ao fazer tal opção. Reforça-se o efeito de que o protagonista é observado de fora pelo próprio narrador, mantido implícito como na última citação, e ainda pelo sujeito da enunciação. Além disso, essa notícia, que poderia ser apresentada como evento excepcional, já que representa uma mudança de percurso, é relatada como fato corriqueiro, que pouco abala o sujeito:

A partir de 1967, mudou sua linha de pesquisa passando a estudar Seleção em Mutantes de Drosophila melanogaster junto com um grupo de estudantes graduados, formando uma nova equipe de pesquisadores (MAGALHÃES, 1978, p. 14).

Encontramos algumas passagens em que se verifica a ausência de verbos. Isso, no entanto, não apaga a progressão temporal, própria da narração, pois a ordem em que os eventos são apresentados no texto indica sua ordem temporal. Além disso, cada fato apresentado é associado a um cronônimo, o que favorece a criação de uma sequência.

Entre 1943 e 1957, atividade dupla, como Assistente de Sociologia na Universidade e crítico literário fora dela. Crítico titular (como se dizia então) da revista Clima (1941-1943), da Folha da Manhã (1943-1945), do Diário de São Paulo (1945-1947). A partir de 1958, opção final pela Literatura, como professor universitário contratado pela recente Faculdade de Assis (CANDIDO, 1974, p. 2).

Contribui também para a organização temporal e ainda para a criação do efeito de realidade, a menção de fatos da história geral ou ao menos acadêmica. Assim, os fatos da vida profissional e intelectual em questão ganham, como referência, esses outros eventos que fazem parte de um conhecimento compartilhado pelo enunciador e pelo enunciatário, em primeiro 
lugar, mas também pela comunidade acadêmica, quando não o são por um grupo ainda maior:

Como resultado dessas pesquisas foram apresentados inicialmente dois trabalhos no XI Congresso Internacional de Genética, realizado na Holanda em setembro de 1963 [...] (MAGALHÃES, 1978, p. 11-12).

É preciso enfatizar que, nesses memoriais, os tempos enunciativos aparecem em raros momentos. Geralmente são utilizados para explicar o conteúdo das obras publicadas ou a visão que o narrador possui de sua área. Em Candido, por exemplo, encontramos o tempo presente num comentário acerca da postura assumida frente ao ensino da análise literária. O presente durativo e, sobretudo, o gnômico são os tempos que aparecem mais, por prestarem-se bem a definições.

Seria preciso mencionar ainda a atenção constante em relação à análise literária como atividade central do ensino. Ela se manifesta sobretudo nos cursos, em grande parte dos quais a Teoria é canalizada para o estudo dos textos [...] (CANDIDO, 1974, p. 5).

Os memoriais costumam começar por uma apresentação do candidato, um dos poucos momentos no qual prevalece o tipo textual descritivo: a figuratividade serve para caracterizar 0 ator do narrado, por meio de enunciados associados a um mesmo momento de referência temporal (não se cria o efeito de um tempo que passa). Esse "autorretrato" constitui uma das raras partes em que encontramos alguma informação a respeito da vida privada e familiar do candidato: se foi ou é casado, se teve filhos, quem são seus pais e ainda onde nasceu. Entretanto, não há nada que ultrapasse as informações que encontramos em documentos civis. O tema dos memoriais do período estudado é mesmo a vida intelectual e científica.

LUIZ EDMUNDO DE MAGALHÃES, filho de Lafayette Magalhães e de Iracema Hugot Cerqueira Magalhães, nascido aos 5 dias de dezembro de 1927, em Guaxupé, Estado de Minas Gerais, casado, Professor Livre Docente do Departamento de Biologia do Instituto de Biociências da Universidade de São Paulo, afastado do cargo a partir de março de 1975 até a presente data para exercer o mandato de Reitor da Universidade Federal de São Carlos (MAGALHÃES, 1978, s/p). 
Os textos que pudemos analisar até aqui têm a eficácia de sua manipulação sustentada pelo apagamento das marcas do sujeito e pela ilusão referencial, garantida graças ao simulacro de precisão das informações, como costuma ocorrer em teses de doutorado. O tom não é de familiaridade ou de intimidade, muito pelo contrário. Cria-se um distanciamento entre enunciador e enunciatário e ainda entre o enunciado e a enunciação. É diferente do que encontramos em uma série de outros memoriais, como mostra o trecho citado a seguir:

Muitos acham que nasceram predestinados a grandes feitos. Eu nasci, sem qualquer predestinação para as alturas, em Birigui, uma cidadezinha qualquer. $\mathrm{Na}$ infância, fui um menino comum. Tive uma meninice típica de interiorano: brincava, passeava, freqüentava o grupo escolar. A família era enorme: primos, tios... Sobre todos pairava a figura do nono. Fiz ginásio e clássico. Fui muito bom aluno. Talvez porque em casa me tenham incutido um profundo senso do dever (FIORIN, 1994, p. 8).

Essas são as primeiras palavras do texto de Fiorin. Não se procura esclarecer quem são os tios, os primos, não se nomeia o "nono"; o que parece importar é a relação familiar e afetiva que possuem com o menino nascido em Birigui. Não há a data do nascimento, da entrada no ginásio ou no clássico. Não ficamos sabendo o nome das escolas pelas quais passou. Constrói-se, nesse memorial, a ilusão referencial de maneira peculiar, ou seja, afastando-se da ilusão de que o discurso mimetiza o real e aproximando-se do discurso que põe em cena a memória, aquilo que ficou guardado como recordação. O outrora apresenta-se, nesse fragmento, como o que não é recuperado de forma precisa, acabada, mas isso já havia sido sugerido desde o "Prelúdio", que anunciava os perigos da memória: "A memória é involuntária, não é faculdade da razão, não produz algo estruturado, é seletiva [...]" (FIORIN, 1994, p. 6).

Notamos, no fragmento citado, o emprego da debreagem enunciativa de pessoa - tanto do enunciado quanto da enunciação -, o que contribui para um grau de subjetivação do discurso maior do que o que se encontra em Candido, Moreira ou Magalhães. O efeito de subjetividade é fortalecido pela debreagem enunciativa de tempo. As palavras do narrador remetem inicialmente a um 
tempo anterior ao momento da enunciação, sem estabelecer outros momentos de referência temporal no texto. Apenas a partir de "Na infância", torna-se possível localizar os eventos como concomitantes a esse período bastante vago, no que diz respeito à sua extensão temporal. Em Arrigucci, aparece, além do tempo e das pessoas do sistema enunciativo, o espaço do aqui, o que insere o narrador e o sujeito da narração no mesmo espaço em que estão seu avô Ermelindo e sua avó (a "conterrânea"). O enunciatário pode também viver, pela leitura, a ilusão de fazer parte da cena narrada:

Meu avô Ermelindo, que não cheguei a conhecer, era de uma família de moleiros e se destinava ao seminário, por vontade do pai, quando decidiu escapulir e aventurar-se no Brasil, como intérprete e tradutor. Aqui encontrou por acaso uma conterrânea [...]. Viram-se e casaram (ARRIGUCCI JR., 1990a, p.1).

Em alguns memoriais, a parte dedicada aos "dados pessoais" também passa, na maior parte dos casos, a ser apresentada com o uso da debreagem enunciativa de pessoa e às vezes de tempo e de espaço. Entretanto, a presença desse item torna-se menos constante e também menos padronizada. Além disso, a iconicidade aumenta. Margarida Petter fala do lugar de origem dos avós, dos pais e mesmo de sua própria origem. O enunciatário pode, com isso, criar para si uma imagem menos genérica dessa "personagem".

Dados pessoais:

Sou neta de imigrantes italianos, de mãe e pai do interior paulista; nascida e criada na Mooca. Há trinta anos estou casada com o Nelson e sou mãe do Danilo, agora com 18 anos (PETTER, 2008, p. 5).

É preciso dizer ainda que, fugindo parcialmente da temática mais encontrada nos memoriais da década de 70 da Faculdade de Letras e das décadas de 70 e 80 do Instituto de Biociências, as obras mais novas não se restringem à apresentação da trajetória intelectual e acadêmica, mas rememoram a infância, a vida dos antepassados, a relação do ator biografado com amigos e familiares. Isso já se evidencia nessas primeiras linhas de Petter. O papel temático não é mais apenas o de figura pública (professor, intelectual, pesquisador), como seria de se esperar num discurso pertencente 
à esfera acadêmica e científica, pois há ênfase também nos aspectos pessoais.

Se nos memoriais mais atuais, como o de Fiorin, Arrigucci e Petter, a debreagem de pessoa é quase sempre enunciativa, as debreagens de espaço e de tempo oscilam, como ocorre nas autobiografias literárias em prosa, entre os tempos e espaços enuncivos, para o narrado, e enunciativos, para a narração. Os feitos passados continuam a ser, na maior parte do texto, localizados temporalmente e espacialmente de forma bastante rigorosa; tudo é muito bem "documentado". Afinal, o enunciador precisa convencer a banca examinadora de suas competências e não poderá fazer isso, caso a veracidade das informações apresentadas seja posta em dúvida:

Nos dias 18 e 19 de outubro de 1975, participei do XIV Seminário do GEL, realizado em Araraquara. (377) (FIORIN, 1994, p. 15).

Também nesses memoriais verificamos a predominância do tipo de texto narrativo; mesmo a elaboração das teses e o desenvolvimento do trabalho intelectual são apresentados, geralmente, segundo tal forma de organização textual. É o que se verifica quando Quadros relata a realização de seu doutorado, com o uso do pretérito perfeito, ordenando as diferentes etapas de sua reflexão no tempo:

Partindo, então, da premissa de que o purismo é um fenômeno de preservação de norma, tomei a metalinguagem objeto de documentos históricos do português do Brasil, para provar que o purismo é fato persistente na língua.

Organizei, para isso, a tese em cinco capítulos. Inicialmente, procurei fundamentar teoricamente o trabalho e apresentei a periodização da língua portuguesa do Brasil, que subsidiou a análise a fim de eleger os documentos metalingüísticos estudados (2006, p. 19: grifos nossos).

Entretanto, outros tipos de texto também aparecem e com frequência cada vez maior. Encontramos o injuntivo quando o narrador indica um "como fazer", ao determinar, por exemplo, quais são as mudanças necessárias para que o país se torne mais digno: 
É necessário que ocorra uma verdadeira mudança de postura da comunidade do Instituto, que deve acreditar na real necessidade de formar professores qualificados, contribuindo para a construção de um país mais digno, no qual a educação seja uma prioridade (URSI, 2007, p. 5).

É comum ainda que os memoriais mais atuais sejam finalizados pela apresentação dos planos para o futuro do candidato, o que dá lugar ao tipo preditivo, cuja perspectiva é a da antecipação:

Desta forma, tenho a pretensão de continuar a desenvolver atividades de ensino, pesquisa e extensão [...] (POMPÊO, 2007, p. 10).

No entanto, o tipo textual que ganhou mais espaço nesse novo modelo de memorial é o dissertativo. São inúmeras as vezes em que o narrador interrompe seu relato para analisar o passado, comparar situações, emitir julgamentos. Especialmente no final dos memoriais, deparamos com o narrador fazendo uma avaliação tanto de sua vida, quanto da experiência de narrá-la. Essa sanção pode aparecer mesclada aos planos para o futuro.

Esse é um momento em que fazemos uma análise das experiências vividas. Sinto-me realizada por ter percorrido esse caminho e aprendido muito. Chegar até aqui, só foi possível com a ajuda de muitos [...]. Como escrevi anteriormente, aprendemos juntos, pois o mundo das plantas é um aprendizado contínuo - não há barreiras, não há fim (ANGYALOSSY, 2006, p. 5).

Entretanto, em algumas das passagens em que o passado é analisado, o tipo narrativo continua imiscuindo-se entre as exposições e opiniões. É o que podemos observar em Lafetá, que mostra as ações do próprio narrador, e não, como na maior parte do texto, as do ator do narrado:

Leio que o censo de 50 atribuiu ao município a população de 72.557 habitantes. Vejo, também, que por volta de 1955 esta cifra se elevava para 81.710 habitantes, sendo cerca de 30 mil na cidade e o restante nos distritos. Os números me parecem altos. Minha lembrança é de uma comunidade pequena, onde as pessoas se conheciam pelos nomes de família e se relacionavam cordialmente - apenas divididas pela rivalidade política entre PSD e PR, sempre disputando a Prefeitura. Visão de classe média, talvez, ignorante dos lavradores e vaqueiros 
que, já naquela época, abandonavam as fazendas próximas, o sertão baiano e o Nordeste, e iam se aglomerando em torno da cidade (1999, p. 14).

O narrador faz nesse trecho uma comparação entre o que diz o censo de 50 a respeito da cidade de sua infância e suas recordações. A descrição da cidade no passado ajuda a construir a oposição entre o mundo lembrado e os dados produzidos pelo censo. Após o confronto, o narrador chega a algumas conclusões a respeito do seu modo de enxergar a sociedade local quando criança. Aparentemente temos a dominância da dissertação nessa passagem; informações são confrontadas para a defesa de uma tese: quando menino, possuía uma visão romantizada e típica de classe média. Entretanto, a argumentação é construída como parte das ações - encadeadas como sequência - que o narrador realiza no presente. Tais ações figurativizam o fazer do narrador: ele primeiro lê a respeito do censo de 50, em seguida, vê o que ocorreu em 50, para só depois comparar as informações ao que ficou na memória. O emprego dos verbos no presente pontual ("Vejo" e "Leio") corrobora nossa análise, pois imprime dinamismo aos eventos narrados, criando relações de anterioridade e posterioridade entre eles.

O narrador dos memoriais não apenas "encena" o seu fazer, mas pode também comentá-lo. Num exercício metadiscursivo, reflete sobre a própria escritura. Vemos revelado o sujeito por trás da narrativa; confirma-se que esta não se faz sozinha, o que enfraquece pontualmente a objetividade. É o que lemos nas primeiras páginas do memorial de Negrão:

O fazer um memorial pode ser comparado à montagem de um álbum de fotografias. [...] Vejo a minha tarefa não só como a da pessoa que mostra seu álbum e, ao explicitar o contexto da foto, reconstrói a história do momento paralisado, imprimindo-Ihe dinamicidade, mas também como a do historiador que busca a explicitação das motivações e a explicação do desenrolar dos fatos relatados (2004, p. 4).

Véronique Dahlet (2004) afasta-se ainda mais do efeito de objetividade, ao iniciar o texto com uma discussão sobre o gênero, que é definido, entre outras coisas, como a narrativa do percurso da vida de uma "personagem". 
Com isso, separa-se o narrador do ator biografado, que é apresentado, nesse momento, como entidade fictícia.

A existência de um sujeito que manipula o discurso pode manifestar-se ainda na discursivização do próprio narrar. Negrão, por exemplo, mostra que cabe ao narrador a organização das sequências temporais no enunciado, pois pode antecipar ou postergar o relato de um evento.

Mas calma lá. Narradora pouco experiente que sou, adiantei-me. Quero voltar ao ano de 1977 (NEGRÃO, 2004, p. 14).

A explicitação do manejo do tempo realiza-se ainda de outras formas. Negrão o faz no nível da narração, mas isso ocorre também no do narrado e por meio de outros recursos. A aceleração conferida ao encontro dos avós, seguido de casamento - "Viram-se e casaram" -, em Arrigucci (1990a), exemplifica tal afirmação. Ela é realizada pela elipse da série de fatos que, geralmente, preenchem o intervalo entre o primeiro encontro e o casamento e que, com certeza, faziam parte das expectativas do enunciatário. A ilusão de transparência da linguagem é posta à prova.

Essas "piscadelas" para o leitor, chamando sua atenção para o sujeito que, com fios invisíveis, controla o discurso-enunciado, fazem com que os memoriais se aproximem dos romances autobiográficos. Reforça essa aproximação o fato de o narrador ser representado, em alguns poucos momentos, lembrando-se ou esquecendo-se de seu passado, ou seja, o discurso figurativiza o funcionamento da memória e ela aparece como a porta para um tempo próprio. Essa "encenação", muito comum nas obras autobiográficas de maneira geral, não se faz presente nos memoriais mais antigos.

[...] não me lembro exatamente em que idade decidira por professora de educação Física (DAHLET, 2004, p. 8).

Lembro-me muito bem do clima alegre, no qual a liberdade e a solidariedade eram os principais valores cultivados (URSI, 2007, p. 2).

Vemos, então, que há diferenças bastante marcantes entre os textos analisados e, a partir de seu exame, podemos propor dois modelos de memorial. 
O quadro abaixo resume os aspectos gerais de cada modelo. Esse quadro não deve e não pode ser tomado como normativo, nem mesmo como uma caracterização definitiva do gênero, pois como diz Fiorin, comentando a definição de gênero de Bakhtin:

O acento deve incidir sobre o termo relativamente, pois ele implica que é preciso considerar a historicidade dos gêneros, isto é, sua mudança, o que quer dizer que não há nenhuma normatividade nesse conceito. Ademais, o vocábulo acentuado indica uma imprecisão das características e fronteiras dos gêneros (2006, p. 64).

\section{MEMORIAL (modelo 1)}

\section{Estrutura composicional:}

- efeito de identidade entre enunciador, narrador e protagonista (ator do narrado), criado por diferentes recursos;

- $\quad$ embreagem enunciva de pessoa - da enunciação e do enunciado;

- dominância da debreagem enunciva de espaço e de tempo - da enunciação e do enunciado -, com predomínio do sistema temporal enuncivo pretérito;

- narração retrospectiva da história e em ordem cronológica (ela vai do período mais distante ao mais recente);

○ $\quad$ organização das atividades em forma de lista;

- $\quad$ predomínio do tipo textual narrativo (pequeno emprego de outros tipos);

- texto figurativo (alto grau de densidade semântica na construção de pessoas, tempos e espaços);

- assunção apenas de papéis temáticos ligados à vida pública e profissional por parte do narrador (enunciador);

- divisão do texto segundo diferentes papéis temáticos assumidos pelo candidato (formação: aluno; docência: professor; entre outros);

- apresentação dos dados pessoais na primeira página (nome, filiação, data de nascimento, etc.);

- encerramento do texto com a data e a assinatura do candidato.

\section{Estilo:}

- rigidez do gênero mantida no encontro com o estilo autoral, inclinação ao apagamento dos estilos autorais; 
- utilização da norma culta em registro formal;

configuração do éthos dependente, entre outros aspectos, da relação que o enunciador estabelece com seu passado;

efeito de distanciamento entre enunciador e enunciatário, criado pelo uso do sistema enuncivo de pessoa;

efeito de distanciamento entre sujeito da enunciação e enunciado, criado pelo uso do sistema enuncivo de tempo e de espaço.

\section{Temática}

- memória da vida acadêmica e intelectual.

\section{MEMORIAL (modelo 2)}

\section{Estrutura composicional:}

- efeito de identidade entre enunciador, narrador e protagonista (ator do narrado), criado por diferentes recursos;

- $\quad$ debreagem enunciativa de pessoa - da enunciação e do enunciado;

- dominância da debreagem enunciativa de espaço e de tempo, quanto à enunciação, e da debreagem enunciva de espaço e de tempo, quanto ao enunciado (predomínio do sistema temporal enuncivo pretérito);

- narração retrospectiva da história e em ordem cronológica (ela vai do período mais distante ao mais recente, havendo poucos avanços e recuos);

- $\quad$ possibilidade de apresentar uma lista das atividades em parte separada;

- predomínio do tipo textual narrativo, com grande presença de outros tipos de texto, especialmente os dissertativos;

texto figurativo (alto grau de densidade semântica na construção de pessoas, tempos e espaços);

destaque para os papéis temáticos profissionais do narrador (enunciador), embora ele também assuma papéis pessoais;

- divisão do texto segundo critérios variáveis (há memoriais organizados a partir de mudança espaciais; outros, segundo diferentes papéis temáticos assumidos pelo narrador, etc);

inclinação a apresentar na primeira página os dados pessoais (nome, filiação, data de nascimento, etc.); 

conclusão;

Estilo:

- pequena flexibilização do gênero no encontro com o estilo autoral, inclinação ao fortalecimento dos estilos autorais;

utilização de diferentes normas linguísticas, com dominância da norma culta em registro formal;

configuração do éthos dependente, entre outros aspectos, da relação que o enunciador estabelece com seu passado;

efeito de aproximação entre enunciador e enunciatário criado pelo uso do sistema enunciativo de pessoa;

efeito de aproximação entre sujeito da enunciação e enunciado, criado pelo uso do sistema enunciativo de pessoa;

- efeito de distanciamento entre enunciador e enunciado, criado pelo uso do sistema enuncivo de tempo e de espaço.

\section{Temática}

- $\quad$ memória da vida acadêmica e intelectual, com integração da vida privada.

Cada modelo de memorial foi mais empregado em certas décadas que em outras. Assim, com relação ao período recortado em nosso estudo, temos que o modelo 1 parece mais recorrente na Faculdade de Letras (USP) na década de 70 e no Instituto de Biociências (USP) nas décadas de 70 e 80 . Já o modelo 2 parece ter encontrado maior produtividade a partir do início dos anos 80 na Faculdade de Letras e dos anos 90 no Instituto de Biociências ${ }^{62}$. É

\footnotetext{
${ }^{62}$ Não temos informação suficiente a respeito das décadas anteriores a 1970. Quanto aos memoriais da Faculdade de Letras, tivemos acesso a apenas dois exemplares da década de 70, o de Antonio Candido (1974) e o de Leyla Perrone Moisés (1975). Ambos possuem as características próprias do modelo 1 de memorial. O texto de Leyla Perrone Moisés não se encontrava disponível na biblioteca Florestan Fernandes (FFLCH-USP) nos meses finais da redação da tese, o que impediu sua citação. A partir da década de 80 , encontramos um número maior de memoriais consultáveis, quase todos pertencem ao modelo 2. Na biblioteca do Instituto de Biociências, há em torno de 20 memoriais da década de 70 . O número de exemplares arquivados aumenta conforme as décadas avançam. Salvo engano, todos os textos da década de 70 e 80 que estão na biblioteca do IB apresentam, de forma dominante, as características do modelo 1. A partir do início da década de 90, o modelo 2 se torna mais frequente entre os memoriais que consultamos.
} 
preciso esclarecer, porém, que os dois modelos conviveram nas instituições ao longo de certo período.

No Instituto de Biociências, deparamos, no início dos anos 90, com textos que apresentam elementos característicos de ambos os modelos propostos. Em 1992, encontramos, por exemplo, um memorial que se utiliza apenas de pessoas, tempos e espaços enuncivos (Castrucci) e outro que faz uso também de mecanismos discursivos enunciativos, especialmente com relação à pessoa (Imperatriz-Fonseca).

Desde a tenra idade, a candidata teve o privilégio de viver em ambiente voltado para a educação e as humanidades, pois é filha de uma professora primária e de um professor universitário, integrado desde o início da carreira no grande movimento cultural que consistiu no aparecimento da Faculdade de Filosofia, Ciências e Letras, no contexto da criação da própria Universidade de São Paulo. Essa vivência, desde os verdes anos, com progenitores imbuídos de uma mentalidade educacional, despertou muito cedo na candidata o pendor por atividades de ensino, ao qual, quando se tornou universitária, juntou-se o desejo de pesquisar no campo em que pretendeu especializar-se (CASTRUCCI, 1992, p. 2: grifos nossos).

Iniciei minha vida acadêmica na Universidade de São Paulo, como bolsista da FAPESP, no terceiro ano do curso de Ciências Biológicas. No Departamento de Zoologia, sob orientação do Dr. Paulo NogueiraNeto, dediquei-me ao estudo das abelhas indígenas. (IMPERATRIZFONSECA, 1992, p. 1: grifos nossos).

É interessante observar que o memorial de Castrucci, que se enquadra de maneira mais ampla no modelo 1, possui algumas diferenças com relação ao que vimos em Candido, Moreira ou Magalhães. Castrucci fala brevemente da infância - os "verdes anos" - para mostrar a influência da família em sua formação. Além disso, menciona o "desejo" de pesquisar, o que traz um mínimo de conteúdo passional para o texto.

Um caso que merece ainda ser comentado é o memorial de Angyalossy. Após a "Apresentação", que traz o relato da vida nos moldes do modelo 2, as atividades são listadas por meio de uma embreagem enunciva de pessoa, cujo efeito é de distanciamento e objetividade, mas comentadas por um narrador que diz eu, o que produz os efeitos contrários: de proximidade e de subjetividade. 
Realizou estágio de Pós-Doutorado no Institut für Holzbiologi und Holzschutz [...].

Esse estágio proporcionou-me a possibilidade de conhecer o mais completo Laminário, de referência, de secções anatômicas de casca de espécies arbóreas tropicais [...]. Entrei em contato com o Dr. Parameswaran em 1980 [...] (ANGYALOSSY, 2006, p. 10).

No trecho citado, mantivemos o modo como a fonte é utilizada no memorial. O itálico, que remete à "letra de mão" e, assim ao texto manuscrito, reporta-se à presença de um sujeito que escreve o texto, individualizando-o, enquanto a forma padrão da fonte cria o efeito de impessoalidade. Esses usos reforçam os sentidos já expressos pela discursivização da pessoa. O memorial de Angyalossy, que possui todas as características do modelo 2, traz, portanto, alguns elementos próprios do modelo 1. É a relativa estabilidade dos gêneros que se deixa apreender, mais uma vez, nesses exemplares.

\subsection{0 éthos do memorialista: "aprovado com distinção e louvor"}

Devemos sempre ter em mente que os memoriais são escritos para um concurso na esfera de circulação científica e acadêmica. Essa situação comunicativa parece, em grande parte dos casos, ser determinante do modo como o éthos será construído, uma vez que a projeção de uma imagem de eficiência, de objetividade, de dedicação e de coerência parece fundamental para que o candidato seja bem avaliado. O papel temático que o enunciador busca construir para si é, essencialmente, o de professor-pesquisador. Assim há uma dupla expectativa que o memorial procura atender: a de mostrar a competência tanto para a pesquisa quanto para a docência.

Iniciaremos pelo exame dos memoriais que se enquadram mais no modelo 1, produzidos na Faculdade de Letras e no Instituto de Biociências da USP. Como vimos, eles são escritos, predominantemente, na norma culta, segundo um registro formal, indicando o domínio da variante de prestígio. Com relação ao léxico, é importante ressaltar a reiterada presença de termos técnicos. Essas características conferem ao enunciador uma imagem de competência compatível com as expectativas relativas à situação de 
comunicação, tanto em relação aos conhecimentos exigidos por sua área de atuação, como à própria escritura do memorial. Não bastaria que o narrador afirmasse conhecer bem a área ou saber fazer um memorial. É preciso que seu dizer "comprove" isso, por meio de, entre outros recursos, o largo emprego da metalinguagem própria à sua área de estudo, como neste caso:

Aproveitando a oportunidade oferecida por um convite para a Conferência Internacional de Endocrinologia Comparada em Málaga, Espanha, a candidata visitou o laboratório do Prof. Dr. Lars Josefsson em Copenhagen, Dinamarca, eminente bioquímico que se dedica ao isolamento e caracterização de neuropeptídeos de crustáceos, com o qual já vinha mantendo correspondência há algum tempo. Estabeleceu assim também com o Prof. Josefsson um projeto em colaboração sobre cromatofotropinas de crustáceos [...] (CASTRUCCI, 1992, p. 4).

Mencionar as experiências científicas, as leituras, as aulas frequentadas, as pesquisas ajuda a recriar ao longo do texto o ambiente próprio do professorpesquisador. É então reforçado o pertencimento do enunciador a esse meio, o que se deixa apreender por meio de algumas isotopias figurativas. São recorrentes as figuras ligadas ao universo da pesquisa científica ou ainda do ensino: "biblioteca", "laboratório", "leitura", "grupo de pesquisa", "estudo", "sala de aula", "classe", "experiência", "aluno", "professor", "tarefa", "ciência", "método", "bolsa de estudo", "universidade", "escola", "discente", "docente", "aprendizado", "mestrado", “doutorado", "prova”, avaliação", "estágio", "congresso", etc. A reiteração semântica confere ainda uma imagem de estabilidade e de coerência ao professor, corroborada por outros elementos que serão comentados mais adiante.

Muitas vezes o relato da participação do candidado em grupos e instituições vem acompanhado por elogios a colegas de trabalho, como se vê no memorial de Castrucci, que fala do "eminente bioquímico" com o qual estabelece uma parceria. Como efeito desse tipo de recurso, ocorre a valorização do próprio candidato, de maneira indireta e sutil. Afinal, se ele trabalha com pesquisadores renomados, deve possuir algum mérito. $O$ enunciador valoriza-se sem criar uma imagem de arrogância.

A referência aos professores que fizeram parte da formação dos memorialistas merece ainda outra reflexão. Em quase todos os textos 
estudados, são indicados os professores que foram "marcantes", ou seja, que serviram como uma espécie de modelo para o candidato por motivos variados: a forma de ensinar, o vasto conhecimento, o caráter, etc. São professores que deixaram impressões indeléveis no modo de ser de seus alunos e orientandos, transformando as competências deles. Encontramos, então, o Dr. Erasmo Garcia Mendes, responsável por elevar o nível de interesse de sua orientanda por determinada área, modificando a relação da aluna com o conhecimento. $O$ excerto seguinte traz, dentro do tópico "Formação", os professores apontados como aqueles que "marcaram":

Como aluna do curso de pós-graduação em Fisiologia do Instituto de Biociências, em nível de doutorado, a candidata continuou a trabalhar sob a orientação do Prof. Dr. Erasmo Garcia Mendes, o qual, experiente também no campo da organização funcional dos cromatóforos, estimulou ainda mais o interesse de sua orientanda pela fisiologia das células pigmentares, descortinando-lhe, agora, o horizonte da pesquisa comparativa nessa área (CASTRUCCI, 1992, p. 2)

Professores que marcaram: Jean Maugüé, História da Filosofia (cursos: Hegel, Schopenhauer, Nietzsche, Freud, Max Scheler) e Roger Bastide, Sociologia 1 (cursos: Métodos, Arte e sociedade, Barroco Brasileiro, Sociologia dos mitos) (CANDIDO, 1974, p. 1).

Os memoriais vão criando, assim, uma espécie de genealogia do candidato. Se nos romances autobiográficos é frequente a apresentação da genealogia familiar, nos memoriais encontramos uma genealogia intelectual. Logo, o enunciador constrói para si uma nova origem, diferente da que the impõe o nascimento - deixada quase à sombra nesses textos -, o que o insere na tradição acadêmica em geral, mas ao mesmo tempo também o filia a uma tradição específica. Afinal, nem todos os professores aparecem no texto ou são considerados "marcantes". Reforça-se, assim, o pertencimento do enunciador ao universo acadêmico, ao mesmo tempo em que já se delineia uma tomada de posição diante das diferentes formas de produção de conhecimento.

O narrador dos memoriais, geralmente, analisa sua vida, dividindo-a em fases que recebem depois uma classificação, o que contribui para a criação do éthos do memorialista como o de um professor-pesquisador apto para o 
trabalho numa universidade, já que essa forma de organização retoma uma característica central dos discursos pertencentes a gêneros que circulam na esfera científica e também na didática. O narrador mostra-se assim como alguém capaz de narrar e analisar seu próprio percurso profissional. $O$ memorial do professor Antonio Candido é exemplar quanto a tais características. Ele encontra-se dividido segundo os itens: A. Atividades básicas, B. Atividades docentes, C. Principais cursos breves, conferências, etc., D. Formação de quadros docentes e de pessoal qualificado, E. Atividades complementares. Cada item, por sua vez, subdivide-se em novos itens.

O reiterado emprego de topônimos ("na Universidade de São Paulo"), cronônimos ("em dezembro de 1960") e antropônimos ("Roberto Schwarz") é próprio do gênero, conforme já foi comentado, produzindo o efeito de um fazer metódico, pressuposto à elaboração do texto. Tudo o que se narra é datado, documentado, comprovado, como deve ser em um texto que faz parte do universo acadêmico. Geralmente o relato é ainda todo permeado pela indicação da documentação que acompanha o memorial e serve de prova "inconteste" do que é narrado.

Contratado em dezembro de 1960 para inaugurar na Universidade de São Paulo o ensino de Teoria da Literatura, o candidato se preocupou desde logo em formar uma equipe, que pudesse continuar $e$ desenvolver as atividades da disciplina recém-criada.

O primeiro elemento recrutado, Roberto Schwarz, foi encaminhado com este intuito para os Estados Unidos no fim de 1961. Lá estudou sob a orientação de René Welleck no Departamento de Literatura Comprada (que engloba Teoria da Literatura) da Universidade de Yale, obtendo grau de mestre. De volta, foi nomeado Assistente no fim de 1963 (CANDIDO, 1974, p. 21).

Cópias dos trabalhos publicados, assim como a documentação das atividades seguem anexas, dispostas de acordo com a numeração citada no texto (CASTRUCCI, 1992, p. iii).

Esse detalhamento, que confere alto índice de iconização às figuras, fortalecendo o efeito de objetividade, conecta-se a outros aspectos discursivos. A linguagem possui pouquíssimas marcas de subjetividade, conforme mostra a escassa utilização de adjetivos com semantização mais emocional, como "horrendo", "maravilhoso" ou "amedrontador", e a quase ausência de advérbios 
modalizadores, como "lamentavelmente". A escolha lexical, de um modo geral, reforça a distância estabelecida entre o enunciado e a enunciação, como se nota na expressão utilizada em Candido (1974, p. 21) para se referir a Roberto Schwarz: "elemento recrutado". O termo "elemento", empregado no sentido de "pessoa tomada como componente de um todo social; indivíduo" (Dicionário Houaiss, 2009), e "recrutado", empregado no sentido de "convocado", apresentam Roberto Schwarz de forma bastante impessoal. O uso dominante da pontuação com baixo impacto emocional - marcado pela rarefação de exclamações e reticências, entre outros recursos - corrobora o tom de uma subjetividade contida. Revela-se, assim, um éthos construído segundo o efeito de distanciamento, que não se deixa levar pelos afetos na tomada de decisões acadêmicas. $O$ grupo formado para assumir o ensino de Teoria da Literatura é apresentado como dotado da qualidade objetiva da "eficiência":

A partir de então, na medida das possibilidades de verba e das necessidades de serviço, foram recrutados outros elementos com 0 mesmo cuidado, estando atualmente o grupo em condições de assumir com eficiência a responsabilidade plena dos cursos de graduação e pós-graduação, sendo os seguintes os seus componenetes [...] (CANDIDO, 1974, p. 21).

A minimização da intensidade passional mostra-se ainda na maneira como o recebimento de prêmios, menções ou medalhas é narrado. Faz parte do memorial apresentá-los; em alguns textos encontramos mesmo um tópico, indicado no sumário, dedicado a essa questão: "Prêmios Recebidos e Distinções" (MAGALHÃES, 1978, p. 65). Entretanto, o relato desses prêmios é feito sem que o narrador revele grande envolvimento emocional. Eles são evocados como uma consequência do trabalho realizado, de forma que o enunciador não aparece como alguém que se vangloria de seus feitos. Isso também se verifica com relação a todas as etapas "vencidas" ao longo do percurso acadêmico (concursos, defesas, pedidos de bolsa, etc), sempre narradas com parcimônia no que diz respeito ao uso dos adjetivos ou advérbios que mostrem a avaliação do narrador e/ou do enunciador. 
Quando, afinal, surgiu uma oportunidade para se tornar docente do Departamento de Fisiologia Geral, a candidata prestou um concurso interno de títulos e provas, e conseguiu sua admissão como assistente doutora do referido Departamento, sob o regime de contrato (CASTRUCCI, 1992, p. 3).

Semelhante emprego da linguagem também ocorre quando o texto trata das descobertas e invenções. Especialmente nos memoriais do Instituo de Biociências, a inovação aparece figurativizada de diferentes formas, tornandose um tema recorrente. Embora com uma frequência menor, a inovação também é encontrada nos textos da área de Letras, como no de Antonio Candido (1974, p. 21) que fala da criação da disciplina de Teoria da Literatura na USP. Os semas da incoatividade recobrem uma boa parte dos textos, construindo o simulacro do enunciador como aquele que, se, por um lado, insere-se na tradição, por outro é um iniciador de novas tradições.

Primeiro levantamento das espécies de isópodas da família Serolidae, feito no sublitoral do Estado: 3 espécies novas são descritas (Serolis

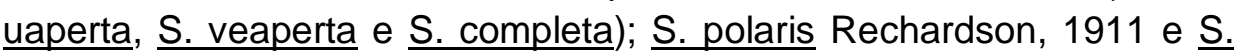
laevis Richardson, 1911 são redescritas e discutidas com base em novos dados morfológicos (MOREIRA, 1971, p. 11).

Até aqui apontamos algumas características de estilo próprias aos memoriais do modelo 1. Entretanto, é preciso lembrar que estamos trabalhando com dois modelos de memoriais e que diferenças significativas podem ser verificadas no modo de construir o éthos em cada um. Uma das principais inovações do modelo 2 é que, nele, o éthos incorpora uma série de características sensíveis. Podemos tomar o termo "sensível" em sua dupla acepção: a que aponta para as paixões, os afetos e a que aponta para o universo perceptivo. Passemos, então, à análise dos textos mais recentes.

Chama a atenção o uso dominante da debreagem enunciativa de pessoa em um texto que circula no meio acadêmico; debreagem enunciativa tanto da enunciação - narrador diz eu - quanto do enunciado - ator do narrado é também designado como um eu. O efeito é de subjetividade. O sujeito por trás da narrativa evidencia-se e ainda revela, em parte, o seu comprometimento e a sua parcialidade em relação ao narrado; afinal, fala de si 
mesmo. Aproxima-se o enunciado da enunciação, assim como o enunciatário do enunciador.

Nasci em uma fazenda de café e desde cedo convivi com o cheiro dos grãos de café secando no terreiro - trago este aroma em minha mente até hoje [...] (ANGYALOSSY, 2006, p. 1).

A debreagem enunciativa está em sintonia com outras mudanças linguísticas verificadas nos memoriais, que contribuem para uma sensibilização maior do éthos. É o caso do emprego de um léxico mais afetivo e sensorial. Revela-se, assim, a presença de um sujeito que está imerso no mundo e o sente, como já se nota no fragmento do texto de Angyalossy, relativo ao "cheiro dos grãos de café", "aroma" que impregnou sua memória. Notamos especialmente o uso de um número maior de adjetivos que expressam qualidades subjetivas ("querido") e avaliações passionais ("incrivel"); algumas vezes são intensificados pelos advérbios ("tão querido", "muito feliz"). Também se tornam mais numerosos os advérbios que revelam como a vida é percebida pelo sujeito que a narra ("freneticamente", "fervorosamente"), os possessivos, que mostram o vínculo do narrador com seu passado ("nosso", "minha"), os verbos e substantivos que remetem ao universo sensorial ou passional ("desejava"). Além disso, as interjeições ("ufa") se fazem mais frequentes e a pontuação é usada de maneira expressiva: a exclamação se torna recorrente no modelo 2.

Todo esse aprendizado não seria possível, sem a presença do nosso querido técnico Antonio Carlos Barbosa [...] (ANGYALOSSY, 2006, p. 5).

E foi assim que conheci a Professora Nanuza Luiza de Menezes!!! (ANGYALOSSY, 2006, p. 1).

Existiam pessoas cuja profissão era estudar, ensinar e fazer pesquisa! Incrível! Era isso que eu queria ser! (URSI, 2007, p. 2)

Foram eles que escolheram o tão querido Colégio de Santa Inês (bairro do Bom Retiro, São Paulo) para minha formação inicial (URSI, 2007, p. 2).

Fiquei muito feliz ao ver a receptividade dos visitantes (Ursi, 2007, p. 9). 
Ufa! 1979 (MATIOLI, 2001, p. 4).

Com o fim do Mestrado e início do Doutorado, comecei a me preocupar freneticamente em conseguir uma ocupação mais segura que aquela proporcionada por bolsas, desejava fervorosamente um emprego (MATIOLI, 2001, p. 5).

Encontramos todos esses elementos lexicais de sensibilização com uma frequência grande nos textos do Instituto de Biociências. Embora menos empregados, esses recursos também aparecem nos memoriais escritos por professores da Faculdade de Letras, como vemos nos excertos citados:

Tudo o que a comissão julgadora não precisava naquele momento era de alguém que ingressasse na universidade como ponte para fazer estágios fora do país. Pude então prometer, aliviadíssimo, que jamais partiria de mim um pedido dessa natureza (TATIT, 2002, p. 61: grifos nossos).

Comecei o curso de mestrado na PUC com muito entusiasmo (QUADROS, 2006, p. 15: grifos nossos).

A menor frequência desses procedimentos não significa que haja uma sensibilização mais fraca do éthos nos textos da Faculdade de Letras, mas apenas que os procedimentos são outros. No caso do éthos do professorpesquisador do curso de Letras, a sensibilização parece resultar principalmente de uma aproximação da linguagem literária, o que é feito por meio de inúmeros recursos, como: recorrência de figuras de linguagem, especialmente, da metáfora; exploração do plano da expressão; estabelecimento de relações semissimbólicas; uso da linguagem em sua função poética. Esses mecanismos também são encontrados nos textos do Instituto de Biociências, mas em gradação menor. $O$ enunciador mostra-se, assim, como um sujeito cuja relação com o trabalho e a vida acadêmica de forma geral é marcada por aspectos subjetivos, mas também como alguém que possui certa competência linguística bastante bem-vinda, especialmente para um profissional da área de Letras, que tem a literatura como um de seus objetos de estudo. Vejamos alguns exemplos. 
Quadros opta por apresentar seus "Dados pessoais" na forma de versos, o que retira a linguagem de seu uso ordinário e é bastante incomum nos memoriais:

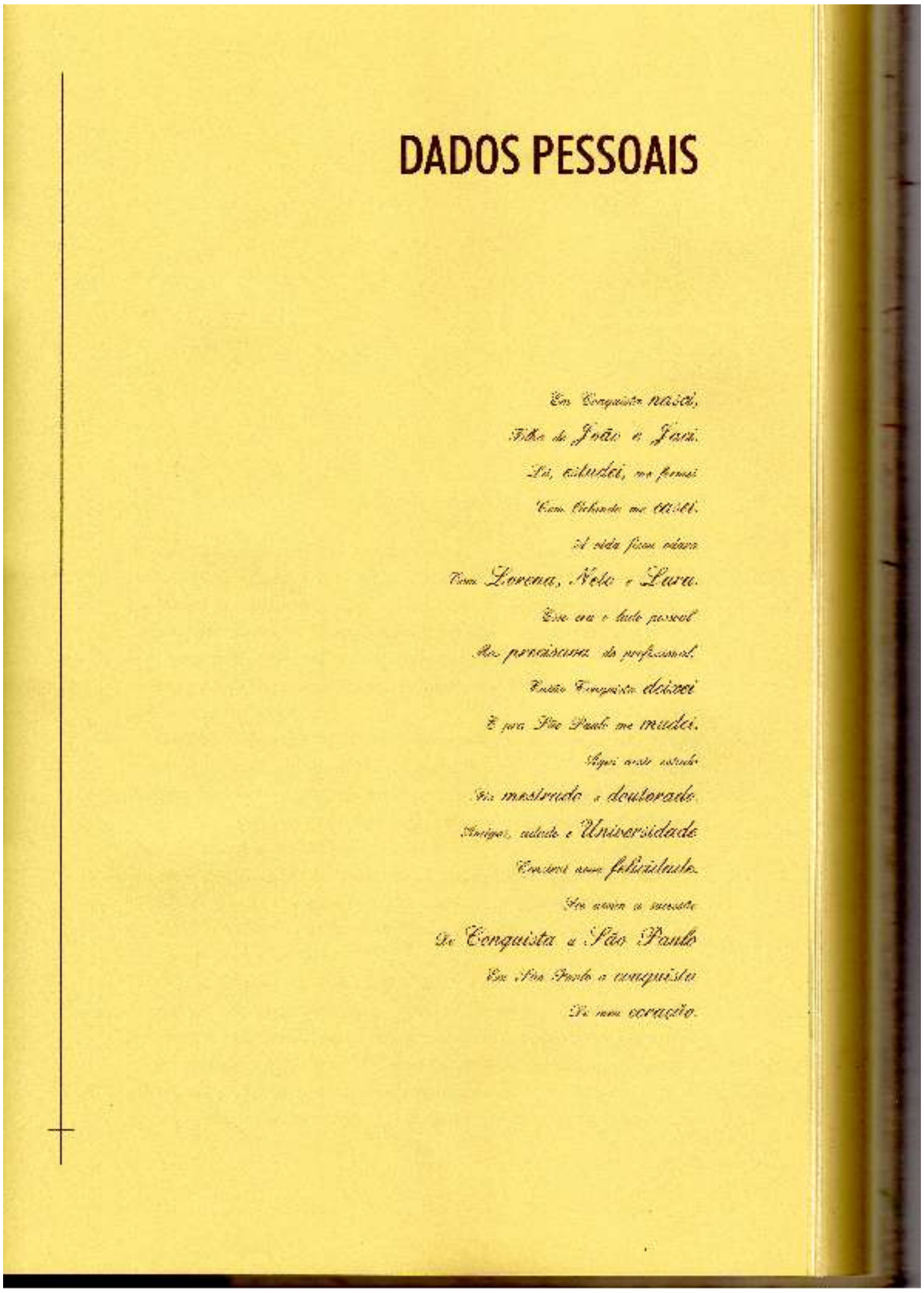

(2006, p. 6) 
O significante é duplamente explorado. A diferença de tamanho das letras imprime certo ritmo ao texto por meio do manejo do plano da expressão visual, chamando a atenção para a materialidade do texto, o que é próprio da obra de arte. A sonoridade é trabalhada pelas rimas emparelhadas (aabb) com exceção dos últimos quatro versos - e pelas rimas internas ("estudei"/ "me formei"). Sempre que há rima, as relações paradigmáticas estabelecidas entre significantes semelhantes são projetadas no eixo sintagmático, caracterizando o que Jakobson (1995) define como a função poética da linguagem: a projeção das relações de similaridade, próprias do eixo paradigmático, no sintagmático.

O poema narrativo, escrito em sua maior parte em redondilhas maiores, remete ao universo da literatura popular, especialmente ao cordel, bastante difundido no Nordeste brasileiro ${ }^{63}$. O relato da trajetória da professora que migra de Vitória da Conquista para São Paulo, em busca da realização profissional, revê a temática do retirante, tão cara a esse tipo de literatura. Assim, não é apenas a forma do conteúdo que nos revela a origem e o percurso de vida do enunciador, mas também a forma da expressão ao permitir o estabelecimento da relação com a literatura de cordel. $O$ emprego da linguagem literária ajuda a compor a imagem do enunciador, revelando suas competências linguísticas e discursivas e ainda individualizando-o. O estilo autoral de Quadros se robustece diante da cena genérica do memorial.

$O$ efeito de subjetividade é garantido, entre outros recursos, pela escolha da fonte - Palace Script MT -, que difere da que é utilizada ao longo do restante do memorial - a Times New Roman, fonte de boa parte dos trabalhos acadêmicos. A Palace Script MT remete ao texto manuscrito. O seu formato arredondado, a continuidade que estabelece entre as letras de uma mesma palavra e a posição inclinada para a direita (a Palace Script MT está em itálico) figurativizam a "letra de mão", manuscrita e peculiar a cada pessoa. Além disso, pelo fato de ser pouco usada, carrega a marca de uma escolha individual. Essa relação é estabelecida em oposição à fonte Times New Roman

\footnotetext{
${ }^{63}$ Reproduzimos o poema: "Em Conquista nasci,/ Filha de João e Jaci./ Lá, estudei, me formei/ Com Orlando me casei/ A vida ficou odara/ Com Lorena, Neto e Lara./ Esse era o lado pessoal/ Mas precisava do profissional./ Então Conquista deixei/ E pra São Paulo me mudei./ Aqui neste estado/ Fiz mestrado e doutorado./ Amigos, cidade e Universidade/ Construí nova felicidade/ Foi assim a sucessão/ De Conquista a São Paulo/ Em São Paulo a conquista/ De meu coração".
} 
que recobre 0 restante do texto. Assim, cria-se a seguinte homologação semissimbólica entre categorias da expressão (no caso, eidéticas) e do conteúdo:

\begin{tabular}{|l|c|c|}
\hline & Palace Script MT & Times New Roman \\
\hline $\begin{array}{l}\text { Forma da } \\
\text { expressão: }\end{array}$ & $\begin{array}{c}\text { arredondado, inclinado, } \\
\text { contínuo }\end{array}$ & retilíneo, vertical, descontínuo \\
\hline $\begin{array}{l}\text { Forma do } \\
\text { conteúdo }\end{array}$ & $\begin{array}{l}\text { efeito de subjetividade } \\
\text { (figura do manuscrito) }\end{array}$ & $\begin{array}{c}\text { efeito de objetividade } \\
\text { (figura do texto datilografado) }\end{array}$ \\
\hline
\end{tabular}

Lafetá conta a sua vida escolar por meio de uma longa enumeração das atividades que realizava, recriando textualmente o movimento redundante da rotina. Os únicos verbos que aparecem estão no pretérito imperfeito com aspecto iterativo; expressam, assim, a duratividade descontínua dos eventos relatados. O efeito é de equivalência entre as diversas atividades (elas poderiam aparecer em ordem diferente, sem prejuízo do sentido) e de repetição. É, assim, evocada a cotidianidade do vivido e seu fraco impacto sobre o sujeito que recorda. A ênfase recai sobre a própria redundância e não sobre cada um dos eventos lembrados. Se as rimas fazem com que relações paradigmáticas estabelecidas entre significantes sejam projetadas no eixo sintagmático, a enumeração faz o mesmo com as relações de semelhança estabelecidas entre os significados, caracterizando também o emprego da linguagem em sua função poética.

Comecei o curso primário no Grupo Escolar Gonçalves Chaves, em 1953. Escola tradicional: professoras severas e disciplinadoras; alfabetização no livro Lili, Lalau e o lobo; hora cívica, comemorações em que recitava poesia (13 de Maio: "Caminheiro que passas pela estrada, /Seguindo pelo rumo do sertão"...); tabuada cantada; aulas de Ciência em que se estudava o esqueleto de uma galinha, a germinação do feijão; História de Minas, assombros e anedotas (Chica da Silva, o Aleijadinho, a Inconfidência), de Montes Claros e do Brasil; redações inspiradas por gravuras que mostravam crianças rosadas, à beira de um riacho límpido, tendo ao fundo um moinho, pretexto para se falar de uma Holanda fantástica, aula de Geografia. Fui bom aluno, cadernos em ordem, deveres feitos, primeiro da classe (LAFETÁ, 1999, p. 14-15). 
Com uma linguagem altamente metafórica, Discini fala da dificuldade que sente em escrever o memorial: "Dói construir a memória". Esse é o início do texto. A metáfora projeta as relações paradigmáticas estabelecidas entre significados (relações de semelhança) na sintagmática do texto, estabelecendo também a função poética. O processo mnemônico, ao ser figurativizado como uma paisagem, é espacializado. O tempo, em sua ação, trança a "vegetação", de onde eclodem jatos de água: a própria memória vindo à tona, relacionada à água por sua fluidez. O medo de deixar o passado emergir concretiza-se como a "ameaça de inundação pela escuridão aquosa". O jogo semântico que se estabelece entre claridade ("terreno batido e claro", "clarões") e escuridão ("sombras", "ensombreadas", "escuros") é a maneira encontrada para opor presente - aquilo que está visível para o sujeito - e passado - o que ficou encoberto pelo tempo -, assim como os estados de alma que despertam cada período: conforto e medo, sucessivamente.

O trabalho com a função poética fica especialmente perceptível quando a narradora fala dos "olhos pingando o agora do agora". A redundância do advérbio de tempo ("agora") intensifica seu aspecto pontual, pois funciona como um divisor da duração. Se o agora recorta uma pontualidade na extensão temporal, o agora do agora, segundo uma lógica concessiva, recorta uma pontualidade dentro da própria pontualidade, fazendo aparecer a temporalidade do instante. Os instantes se sucedem, sem, no entanto, haver continuidade entre eles. O sentido expresso pelo conteúdo é reiterado pela expressão, já que a repetição do advérbio "imita" o movimento do gotejar: durativo e descontínuo.

Dói construir a memória. Dói crer que é possível fazê-lo. Estouram borbotões de toda espécie de água das barrancas mais ensombreadas pela vegetação trançada do tempo. Há ameaça de inundação pela escuridão aquosa. Se se foge, entretanto, para terreno batido e claro, com olhos pingando apenas o agora do agora, há, entre outros, o perigo de ter o olhar bebido pela tristeza das sombras renegadas. Avancemos, então; ou melhor, recuemos. É bom lembrar, aliás, que falar de escuros é também falar de clarões, já que em ambos habita a luz, quer como ausência, quer como presença (DISCINI, 2002, p. 8).

Conforme ilustram os três fragmentos citados (Quadros, Lafetá e Discini), os memoriais, especialmente da Faculdade de Letras, muitas vezes se 
utilizam da linguagem literária. Os efeitos disso para a construção da imagem do enunciador são diversos, variando de texto para texto, o que funda o estilo autoral. Entretanto, em comum, encontramos a projeção do simulacro do escritor: aquele que domina a linguagem verbal e sabe expressar sua individualidade por meio dela.

Contribui também para a mudança na imagem do enunciador dos memoriais o espaço concedido à vida privada e, especialmente, à infância, o que é próprio das obras autobiográficas de maneira geral. Arrigucci recupera as histórias de família ouvidas quando menino; Pompêo fala de quando conhece sua esposa:

Desde pequeno ouço de meu pai e parentes o relato do encontro junto à porteira da Aliança. Narrativas como essa sempre me encantaram. Do lado de minha mãe, a vida da roça, a família muito grande, as caçadas e pescarias de meu avô e de meus tios, tudo se multiplicava em histórias sem fim. Creio que isto constitui o primeiro fato memorável que tenho para contar, agora que se trata de relatar minha formação e minha experiência com a literatura (ARRIGUCCI JR., 1990a, p. 1).

Foi também nesse período que conheci a Viviane, que viria a ser não só minha namorada, mas esposa, mãe do meu filho, minha parceira profissional e a luz que falta na nossa vida solitária (POMPÊO, 2007, p. $5)$.

A inserção de fotografias nos memorias do modelo 2 também aponta para o que estamos chamando de uma sensibilização do éthos, e menos para a contrução da ilusão referencial. É o caso da foto que representa uma paisagem e é antecedida pela reprodução da letra de uma canção do grupo Cidade Negra. Nesse caso, a imagem revela a relação passional que a memorialista possui com seu trabalho, além de dialogar com a canção, ao reiterar a figura do caminho, retomada inúmeras vezes nesse texto: 

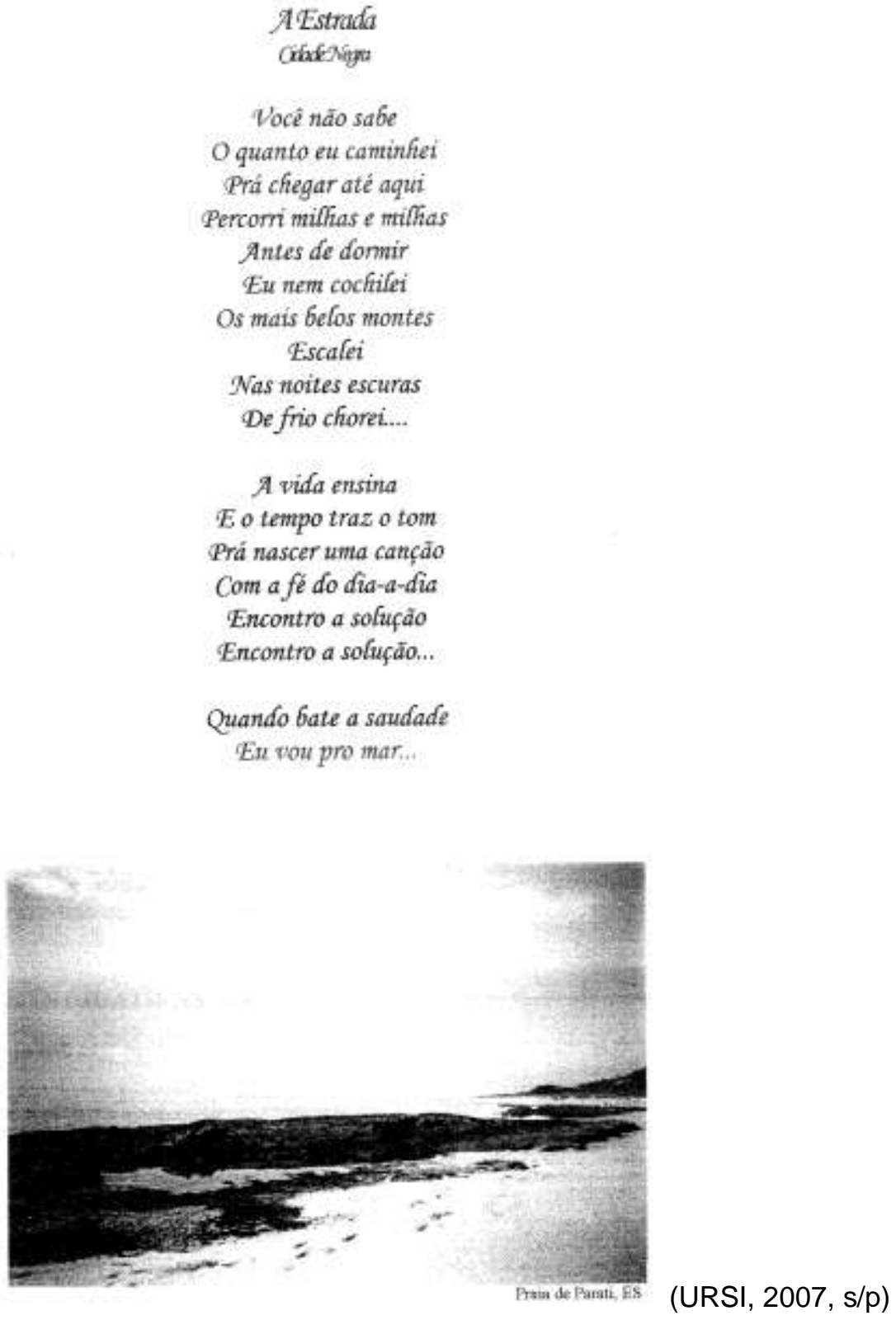

As fotografias, no entanto, constituem um recurso bastante raro. Encontramos, entre os textos pesquisados, apenas dois que trazem imagens, ambos pertencentes a professores do Instituto de Biociências. Em Pompêo, a foto, inserida no item "Dados pessoais" (2007, p. 3), apresenta a família do memorialista: sua esposa e filho. Ela tanto o individualiza, quanto contribui para mostrar que ele reconhece a importância dos aspectos pessoais para o desenvolvimento acadêmico e, em última instância, que ele possui outras dimensões, além das ligadas ao trabalho.

Entretanto, insistimos na ideia de que a temática central continua sendo a vida profissional e intelectual do candidato, já que a esfera pessoal recebe, 
geralmente, foco pequeno e a infância é, em diversos casos, conectada ao desenvolvimento profissional futuro. A esposa de Pompêo, bastante retratada em seu texto, é também bióloga e os dois realizam alguns projetos profissionais juntos, daí talvez o espaço concedido a tal ator. Arrigucci fala do interesse que tinha, quando criança, pelas histórias contadas em sua família, revelando os primeiros indícios de um gosto profundo pela literatura. Neves indica que razões pessoais o fizeram deixar a Amazônia, mas não as explicita. A gravidez da companheira é mencionada por Tatit em meio a um turbilhão de informações sobre as diferentes atividades e compromissos assumidos na mesma época.

Razões pessoais e profissionais fizeram-me decidir deixar a Amazônia, não obstante minha paixão absoluta pelo Museu Goeldi. As razões pessoais não serão tratadas aqui. Falta-me o dom para encontrar palavras apropriadas que de fato possam comunicar a intensidade das emoções pessoais que vivi entre 1988 e 1992 e que me moveram outra vez em direção ao sul do país (NEVES, 2007, p. 12).

Entrei nos anos oitenta em plena ebulição. A idéia de gravar o primeiro disco do Rumo não era mais apenas um desejo, mas uma real necessidade. O mergulho do Brasil em "perpétua" crise econômica, bem como o altíssimo custo e a enorme complexidade de uma gravação naquele tempo, empurravam-nos para uma iniciativa independente com todos os riscos que isso significava. Minha dissertação de mestrado avançava rapidamente embora dispusesse de pouquíssimo tempo de trabalho (não associava pós-graduação com bolsa de estudo e ninguém me havia alertado para essa possibilidade): mantinha de trinta a quarenta alunos de violão durante o ano letivo. Para completar, Rosa Lavelberg, minha companheira desde o início de 1979, esperava nosso primeiro filho (TATIT, 2002, p. 31).

Outra diferença entre os textos do modelo 1 e os do modelo 2 é que, nas páginas finais destes, há, normalmente, uma apresentação dos planos, conforme já foi comentado. O olhar prospectivo é algo que não encontramos muito nas autobiografias literárias (romances e poemas autobiográficos). A primeira conclusão que podemos tirar a partir disso é que a situação do concurso cria como expectativa um candidato que não encerra o trabalho após seu término. Dessa maneira, o enunciador reforça o compromisso que possui com a instituição, ou seja, enfatiza que está modalizado por um não-poder-nãofazer e que continuará trabalhando sempre. Além disso, o planejamento traz 
para o texto a previsibilidade, tão própria do fazer científico, que, ao buscar regularidades, encontra leis que permitem fazer projeções.

No entanto, é pertinente investigar por que os planos não estavam tão presentes nos memoriais do modelo 1, que são finalizados com as últimas atividades realizadas pelo candidato. Se observarmos os trechos do modelo 2 selecionados para a análise, veremos que, no primeiro exemplo, o narrador se apresenta como alguém que deseja algo e, no segundo, como alguém que pretende algo. Nos dois casos, o narrador está mobilizado, então, não só pelo dever, mas também por um querer. Constrói-se o éthos daquele que possui um vínculo passional com seu trabalho, que não consegue deixar de fazer planos para o futuro envolvendo a docência ou a pesquisa, o que vai na mesma direção das demais características levantadas do modelo 2.

E tenho já o tema para ser pesquisado depois disso. Desejo fazer um estudo comparativo entre as vanguardas históricas européias e o Modernismo brasileiro, do ponto de vista da representação da "modernidade". Inspiro-me nos estudos de Walter Benjamin sobre Baudelaire, e quero examinar como certos temas e traços estilísticos, ligados à cidade cosmopolita, aparecem nas vanguardas francesas do início do século e nos modernistas brasileiros. Para isso, estou no momento planejando passar o ano de $1981 \mathrm{em}$ Paris, estudando os movimentos vanguardistas (LAFETÁ, 1999, p. 40).

Desta forma, tenho a pretensão de continuar a desenvolver atividades de ensino, pesquisa e extensão no Depto. de Ecologia (IB, USP), de ampliar as abordagens e parcerias e fomentar a formação de recursos humanos. Viso elevar o nível educacional e de conscientização da população brasileira, mas sem me esquecer das publicações em revistas especializadas de alto nível de impacto. O Depto. de Ecologia pode contar com minha competência e companheirismo, auxiliando nas tarefas rotineiras do dia a dia e nas eventuais (POMPÊO, 2007, p. 10).

É importante observar ainda que, apesar das diferenças entre os dois modelos de memorial, há muitos aspectos da imagem do enunciador que perpassam ambos. Os textos do modelo 2 continuam a ser escritos, predominantemente, na norma culta, confirmando a competência linguística do enunciador e seu lugar de prestígio na sociedade. O registro passa, porém, a ser mais variado. Há textos bastante formais, mas há outros que permitem a entrada de alguma informalidade (ou talvez de um pouco menos de formalidade). Ela pode manifestar-se na escolha do léxico, na sintaxe frasal, no 
modo de empregar a pontuação, o que leva à produção de diferentes efeitos de sentido: de irreverência, de cumplicidade, de intimidade, entre outros. É o que encontramos no memorial de Matioli, em que "maluco" aparece como adjetivo de "ano", o que já demonstra um pequeno grau de informalidade. Além disso, a passagem citada tem início com dois períodos curtos - sendo o segundo construído sem verbos - que introduzem o ano de 1978 de forma abrupta. O enunciatário é convocado, assim, a não mais olhar de fora o relato pormenorizado do passado, mas a vivenciar a chegada repentina daquele "ano maluco", partilhando com o enunciador tal experiência de maneira sensível.

As reticências, após o anúncio da "ironia" que toma a vida do candidato, deixam o espaço necessário para que o enunciatário complete a frase, tornando-se uma espécie de cúmplice do enunciador. O substantivo "penitência", seguido da exclamação, mostra, numa construção informal para um texto acadêmico, os sentimentos do narrador com relação aos caminhos que sua vida tomou. $O$ enunciado é, então, aproximado, por meio de recursos diversos, da enunciação e, assim, do enunciador e do enunciatário.

É interessante notar, entretanto, que o verbo "bombar" é empregado entre aspas. O substantivo "bomba" pode ser encontrado no Dicionário Houaiss (2009) com o sentido de "reprovação em exame", mas é qualificado como "uso informal". O neologismo "bombar" nem mesmo aparece no dicionário. As aspas possuem a função aqui de introduzir o que Authiez-Revuz (1982) chama de heterogeneidade discursiva marcada, separando o que é próprio do discurso do enunciador, do que é voz atribuída a um outro. Com isso, o enunciador demarca bem o lugar de onde fala, o que evidencia os limites que a variação de registro encontra nos memoriais. Afinal, como já dissemos, são textos pertencentes à esfera acadêmica de produção e comunicação.

Era 1978. Ano maluco para mim. Tinha que me formar em Licenciatura e Bacharelado, sendo que havia "bombado" em duas disciplinas: Invertebrados II e Bioquímica. Aliás, aqui uma ironia, alguma parte de minha carreira foi estudar bioquímica de insetos... Penitência! (MATIOLI, 2001, p. 4).

O emprego de termos técnicos também continua a ser grande, conferindo ao enunciador a imagem de competência necessária à situação do 
concurso, como notamos em Angyalossy. No entanto, a maneira como são trazidos ao texto pode variar. Matioli utiliza o símbolo matemático " $n \rightarrow \infty$ " para se referir ao número de vezes que leu determinado livro. O deslocamento do símbolo do discurso matemático para um outro que trata da vida acadêmica gera o efeito de humor e imprime ao éthos alguma leveza e descontração. Esse tipo de "brincadeira" discursiva aparece somente quando o narrador comenta passagens de sua vida, mas jamais quando está tratando de algum trabalho científico. Nesses momentos, o tom é sempre de maior seriedade. Assim, se depreendemos dos memoriais do modelo 2 um corpo menos rígido do que o dos primeiros textos, isso não aponta para a frouxidão, mas antes para a maleabilidade.

Li $n \rightarrow \infty$ vezes a referida coleção e tenho certeza que cada figura e parágrafo estão profundamente inseridos em alguma parte da minha memória (MATIOLI, 2001, p. 3).

No caso da Faculdade de Letras principalmente, a metalinguagem é ainda utilizada em outra situação: a reflexão sobre o gênero memorial acadêmico. O narrador faz de seu próprio texto um objeto de estudo e, assim, deixa ver sua competência no trabalho dentro de sua disciplina. Toma certa distância em relação à narração para poder examiná-la, reforçando a imagem do pesquisador. Ele torna então não somente a sua vida um objeto de análise, mas também a própria narração, concernente ao gênero discursivo.

Memorial é um texto em que são consignados fatos de que se quer lembrar. Esse termo é derivado de memória, a faculdade de conservar e de lembrar estados de consciência passados (FIORIN, 1994, p. 4).

A construção da imagem do pesquisador competente é reforçada também nesse modelo de memorial pela abundância de topônimos ("UFSCar", "Laboratório de Limnologia"), cronônimos ("janeiro de 1984") e antropônimos ("Prof. Dr. Francisco de Assis Esteves"), bem como pela presença das indicações que apontam para a documentação ("Doc.10"). O simulacro de um fazer metódico pressuposto à elaboração do texto não é, então, enfraquecido nos textos do modelo 2. 
$\mathrm{Na}$ UFSCar, em janeiro de 1984, iniciei estágio no Laboratório de Limnologia, coordenado pelo Prof. Dr. Francisco de Assis Esteves (POMPÊO, 2007, p. 5).

Como o concurso seguinte foi realizado apenas em meados do ano de 1976, reunimo-nos aproximadamente durante três anos, três noites por semana, com tarefas a serem cumpridas, dando prioridade aos estudos de Linguística (Doc.10) (DISCINI, 2002, p. 13).

Relato aqui de modo sucinto as principais atividades científicas, didáticas, de extensão e administrativas que desenvolvi até o presente. A documentação pertinente segue em anexo (RODRIGUES, 1996, p. 2).

Também não são menos evidenciadas as descobertas e invenções, introduzidas no texto com 0 aspecto da incoatividade. Especialmente nos memoriais da área de Biociências, o enunciador constrói-se entre a continuidade e a ruptura, conforme já mencionamos. Se, por um lado, mostrase como inserido numa tradição científica e acadêmica, por outro, também cria o simulacro do cientista inventor ou descobridor, que renova a área, deixando entrever a importância de suas contribuições. Há, então, um equilíbrio sutil e bastante tenso que se estabelece entre renovação e manutenção e que parece necessário à construção de uma boa imagem do enunciador.

Compreendi que ir para Abidjan não era uma aventura; eu tinha a missão de trazer para nossa universidade o conhecimento das línguas africanas e deveria implantar essa área de estudos no departamento de lingüística (PETTER, 2008, p. 131).

O trabalho de elaboração de um banco de dados das madeiras brasileiras seguiu, mas sob outro prisma - agora utilizando o computador para armazenar e fornecer dados sobre as mesmas trabalho este pioneiro no Brasil na época (ANGYALOSSY, 2006, p. 2).

Minha pesquisa sobre os primeiros americanos passou a ter a partir de 1998 grande visibilidade midiática, sobretudo após as descobertas efetuadas por mim e por Joseph Powell, da University of New México, sobre Luzia, se não o mais antigo, um dos mais antigos esqueletos humanos já encontrados no continente americano (NEVES, 2007, p. 13).

Eu, em conjunto com o químico Nelson da Silva César Junior, fomos os primeiros a explorar as cavernas areníticas no município de Altinópolis, trabalho apresentado no I Simpósio Paulista de Espeleologial, ocorrido 
na UFSCar, em setembro de 1981, evento organizado pelo GAE (POMPÊO, 2007, p. 4-5).

Como no memorial de Castrucci, nos textos mais recentes os comentários a respeito da participação do candidado em grupos e instituições são, geralmente, mesclados a elogios, que acabam por recair, de forma indireta, sobre o próprio enunciador. É o que notamos quando Pardini fala da "oportunidade" e do "privilégio" de trabalhar no grupo do Dr. Metzger ou quando Neves se refere à "pérola" que pôde "agregar" a seu currículo: "um dos mais importantes paleo-antropólogos de nossos tempos".

Vejo a oportunidade de participar do grupo do Dr. Metzger como um grande privilégio (PARDINI, 2007, p. 6).

O estágio de pré-doutorado que realizei na Califórnia me permitiu, também, agregar a meu currículo uma outra pérola: o de estudar osteologia avançada sob orientação do Dr. Tim White, em Berkeley, um dos mais importantes paleo-antropólogos de nossos tempos (NEVES, 2007, p. 9).

Nesses memoriais, também encontramos os professores que foram importantes e serviram de "modelo" a seus alunos e orientandos, criando ao longo do texto uma genealogia intelectual, conforme já foi comentado. Isso fica bem explícito no texto de Angyalossy, que aponta a Professora Nanuza como um exemplo a ser seguido, ou no de Quadros, quando a narradora, ao agradecer ao Prof. Dino, sugere que aprendeu com ele um modo de estar na Universidade: o da participação. Muda, porém, a maneira como esses professores são apresentados, pois nos memoriais do modelo 2 podem ser figurativizados de modo a revelar o vínculo afetivo que o candidato possui com eles. Angyalossy, algumas páginas antes de dizer que buscava espelhar-se na professora Nanuza, afirma que ela "com um carinho de mãe" cuidava de seus "passos científicos" (2006, p. 1). A maternidade insere-se na isotopia temática da genealogia - Angyalossy vê-se como uma descendente da professora -, mas também serve para qualificar a relação existente entre as duas. A professora é vista como aquela que cuida, protege, dá afeto. 
Tentei espelhar-me na Professora Nanuza, que sempre soube cativá-los com sua forma entusiástica de demonstração de amor à ciência (ANGYALOSSY, 2006, p. 4).

Posso afirmar que o Prof. Dino é responsável por grande parte de minha participação na Universidade de São Paulo, e sou-lhe grata por todo apoio que sempre me deu (QUADROS, 2006, p. 17).

Outro ponto comum aos dois modelos de memorial é o modo como a análise da vida é feita: por meio de uma divisão em fases, etapas, que são nomeadas e classificadas, construindo o éthos do bom analista, como vemos em Walter Neves:

Minha carreira científica pode ser dividida em três grandes fases, coincidentes com três inserções institucionais distintas. A primeira fase cobre o período de 1978 a 1975, e está intimamente relacionada com minhas atividades no extinto Instituto de Pré-História da USP. A segunda corresponde ao período que me dediquei à implantação do Núcleo de Biologia Humana, no Museu Paraense Emílio Goeldi (19861992), e a terceira vai de 1992 ao presente, correspondendo a atividades desenvolvidas à frente do Laboratório de Estudos Evolutivos Humanos, no Departamento de Genética e Biologia Evolutiva, do Instituto de Biociências da USP.

Durante essas três fases transitei três campos distintos de conhecimento, tanto no que se refere à pesquisa, quanto ao ensino e à extensão (NEVES, 2007, p. 6 ).

Em muitos dos memoriais do modelo 2, essa divisão aparece anunciada na "Introdução", na "Apresentação" ou em suas primeiras páginas, informando o leitor a respeito da maneira como está organizado tanto o texto, quanto a vida narrada. Essas páginas iniciais podem ainda apresentar os objetivos do texto, como se faz normalmente em monografias, dissertações, teses, artigos científicos. "Voltar o olhar ao passado, enxergar o presente e vislumbrar o futuro. Eis o objetivo de um memorial" (2007, p. 7), afirma a narradora Marli Quadros, que organiza a sua vida em duas grandes fases. Trata-se de algo que não se encontra nas autobiografias literárias ou pelo menos não com muita frequência. A própria presença de uma "Introdução", tal como elaborada em alguns memoriais, é peculiar ao gênero institucional e estranha às obras autobiográficas de modo geral. Isso porque ela não faz parte da forma composicional de gêneros predominantemente de tipo textual narrativo, mas 
daqueles em que prevalece o dissertativo, dominante nas teses, dissertações e artigos científicos. O mesmo se pode dizer a respeito da seção "Palavras finais" ou "Conclusão", que muitas vezes encerra os memoriais por meio de uma avaliação do que passou. Busca-se nessas partes verificar se os objetivos da vida foram atingidos, e ainda propor os planos futuros. É reforçada, assim, a inserção desse gênero no universo do discurso científico e ainda do enunciador no meio acadêmico.

Voltar o olhar ao passado, enxergar o presente e vislumbrar o futuro. Eis o objetivo de um memorial. E é exatamente com esse intuito que redijo este documento. Lançando um olhar avaliativo sobre o que passou, vejo que a minha história está dividida em fases: a primeira, o início da vida profissional até a definição dos estudos de pósgraduação, e a segunda, a definição e desenvolvimento da carreira universitária. Analisando o passado e o presente, tenho condições de interpretar minha atuação na universidade como professora e pesquisadora para, sempre, projetar o futuro (QUADROS, 2006, p. 7).

Esse trecho conclusivo, próprio à forma composicional de boa parte dos textos científicos, vem acompanhado também de um número maior de passagens em que o texto se organiza segundo o tipo dissertativo. Isso aparece principalmente nos trechos em que o narrador reflete a respeito do seu trabalho, das atitudes tomadas no passado, da escritura do memorial e, mais raramente, da memória, conforme já foi comentado. Podemos tomar como exemplo uma passagem de Arrigucci, em que o narrador interrompe o seu relato para debater sobre o papel do crítico. Nesse trecho, é utilizado o presente gnômico ("é” e "implica”, "resulta”), que apresenta definições como atemporais, enquanto são estabelecidas relações lógicas entre os argumentos, como fica sugerido pelo uso do verbo "implicar".

O crítico, na verdade, é uma personalidade crítica, alguém que capaz de ler e compreender sensível e criticamente o novo, sem reduzi-lo completamente, de modo conformista, apenas ao já sabido. Quer dizer: implica a formação de uma personalidade, o processo lento e difícil da experiência que resulta numa integração complexa dos diversos fatores heterogêneos com que se depara a cada passo (ARRIGUCCI JR., 1990, p. 7). 
Não é apenas o tipo dissertativo que se faz mais presente nos memoriais mais novos, mas também o injuntivo, conforme mostramos. Seu emprego remete à esfera didática e confere ao enunciador o tom professoral. $\mathrm{O}$ enunciador ocupa assim o lugar daquele que detém um saber e ainda um saber que modaliza um fazer-saber, ou seja, ele aparece não apenas como detentor de certos conhecimentos, mas como capaz de transmiti-los.

Isotopias figurativas ligadas ao universo da pesquisa científica ou do ensino perpassam também os dois modelos de memorial. Repetimos que a reiteração semântica reforça uma imagem de estabilidade e de coerência atribuída ao enunciador. Walter Neves (2007) abre e fecha o seu texto falando do Instituto de Pré-História da USP. Matioli (2001) inicia e encerra o seu memorial com as figuras do "experimento" e da "explosão".

A comparação entre o modo de construção do éthos dos dois modelos de memorial permite afirmar que houve mudanças, o que revela que o contrato veridictório também sofreu alterações. Seria possível apontar diversos elementos distintos, relativos a essa transformação, como o aumento da cumplicidade entre enunciador e enunciatário, o que se deve, entre outros fatores, ao emprego de certas estratégias discursivas que criam os efeitos de aproximação e de subjetividade (uso da $1^{\text {a }}$ pessoa, emprego de figuras passionais, etc.). Entretanto, há dois aspectos que merecem maior destaque.

O primeiro diz respeito a uma dimensão do prazer que aparece como exigência desse novo modelo de memorial acadêmico. Conforme mostramos, a imagem do enunciador remete a um sujeito que sente o mundo representado, ou seja, o passado emergente na linguagem. Guiado não apenas por um dever, mas também pelo querer, constrói-se como alguém cuja relação com o trabalho, com a vida profissional, é fonte de prazer. E aqui podemos recuperar o prazer em dois sentidos diferentes, ligados às duas acepções de "sensível", já comentadas.

Parret (2006) mostra que há uma classe de prazeres que, livrando-se da necessidade, conquistaram a autonomia: prazeres lúdicos, prazeres gratuitos. A experiência estética faz parte desse grupo. A outra classe de prazeres está associada à satisfação de uma necessidade. Assim, haveria duas maneiras de sermos afetados: pelas sensações e pelos desejos. Cada uma dessas classes insere-se em uma tradição filosófica diferente. 
Entretanto, o que o autor busca é estabelecer um fundo comum a essas duas formas de prazer. Assim, encontra o corpo como substrato necessário nas duas perspectivas: corpo-desejo e corpo-sensação, duas figuras do que chama de corpo-em-vida. O corpo aproveita tanto os desejos em profundidade (vertical) quanto as sensações de superfície (horizontal), sendo o prazer tributário de ambos, conforme lemos em Parret que afirma ser o prazer a "[...] interface das necessidades e das sensações. E o corpo-em-vida é o nó do corpo-desejo e do corpo-sensação" (2006, p. 142; tradução nossa) ${ }^{64}$.

Além disso, nas duas formas, o prazer é sempre vivido por nosso corpo como não-dor. Parret busca descrever o que chama de "momento essencial do prazer", que seria a vivência de um alargamento do tempo da presença, de maneira que nenhum suplemento de duração possa ultrapassá-lo (condensação temporal), somado a uma difusão corporal, já que é o corpo em sua unidade (e assim totalidade) que vive o prazer: "O prazer em sua plenitude implode e explode, tensividade constitutiva do prazer do corpo-em-vida. Esta é a verdade do prazer" (2006, p. 133; tradução nossa) ${ }^{65}$.

Reconhecemos essas duas formas de prazer colocadas em cena nos memoriais mais recentes. Em alguns, como no de Quadros, o trabalho universitário aparece como realização de um desejo: "uma tendência forte", "uma convocação". A intensidade do querer faz com que o sujeito praticamente perca o domínio de si, como se, cindido em dois, fizesse desse estado passional um destinador que vem tomar, de certa forma, o controle da situação. O "prazer de ter feito algumas pessoas reconhecerem o alfabeto" é a recompensa por buscar o objeto desse querer intenso. O prazer liga-se nesses casos à noção de vocação. Neves também fala do desejo que se impõe ao sujeito, figurativizando-o como "necessidade quase visceral", ou seja, "algo que não se pode evitar" e ainda que está arraigado, que é íntimo (HOUAISS, 2009), no sentido de que perpassa o corpo em toda a sua profundidade. Ursi menciona a descoberta da possibilidade de fazer do estudo e da pesquisa justamente as atribuições do professor universitário - uma profissão. O prazer dessa descoberta é expresso pelas interjeições e pelo adjetivo "incrível".

64 "[...] interface des besoins et des sensations. Et le corps-en-vie est le noeud du corps-désir et du corps-sensation"

65 "Le plaisir dans sa plénitude implose et explose, tensivité constitutive du plaisir d'un corps-envie. Telle est la vérité du plaisir". 
Ainda consigo sentir $\mathbf{o}$ prazer de ter feito algumas pessoas reconhecerem o alfabeto, assinar o próprio nome e ler algumas palavras. Essa era uma tendência forte em minha vida, uma convocação da qual não poderia passar ao largo (QUADROS, 2006, p. 10: grifos nossos).

Como disse anteriormente, a Amazônia cobra uma certa fidelidade regional de seus cientistas. Imagino que isto deve ocorrer em qualquer área do planeta com o mesmo nível de idiossincrasias naturais, sociais e políticas. O fato é que eu, ao final dos anos 1980, estava me tornando a passos largos um amazonista, e eu nunca quis me transformar em qualquer tipo de "ista". Além disso, eu já estava sentindo uma necessidade quase visceral de voltar a dedicar uma boa parte de meu tempo a materiais esqueletais humanos de origem arqueológica (NEVES, 2007, p. 12: grifos nossos).

Existiam pessoas cuja profissão era estudar, ensinar e fazer pesquisa! Incrível! Era isso que eu queria ser! (URSI, 2007, p. 3: grifos nossos).

O período da infância, quase ausente nos memoriais do modelo 1, tornase assim de grande relevância. É possível localizar no passado mais remoto a vontade de pesquisar, de ser professor, de conhecer, de experimentar. Essa vontade estabelece a direção para o percurso do sujeito.

Encontramos também nos memoriais a outra forma de prazer. A relação do sujeito com o mundo é, então, mostrada como pautada por aspectos sensoriais, o que resulta em fruição. Como um bom vinho, o conhecimento do professor acaba por "inebriar" Neves. A satisfação de entrar em contato com um vasto saber é vivida como entorpecimento do corpo (sensação tátil). Angyalossy recorda em tom saudosista o "cheiro dos grãos de café"; a intensidade do aroma é responsável por fazer com que o sujeito no presente possa ainda senti-lo como impressão fixada na memória.

Seu conhecimento quase ilimitado sobre a diversidade social e cultural das populações primitivas, maiormente sobre as populações indígenas brasileiras, me inebriava e foi o trampolim a partir do qual enveredei para os estudos sobre sociedades de caçadores-coletores e sobre sociodiversidade humana em geral, seja via arqueologia, seja via antropologia de populações a nós contemporâneas (NEVES, 2007, p.7). 
Nasci em uma fazenda de café e desde cedo convivi com o cheiro dos grãos de café secando no terreiro - trago este aroma em minha mente até hoje [...] (ANGYALOSSY, 2006, p. 1).

Essa classe de prazeres pode ainda se revelar no emprego de uma linguagem mais literária, que traz para o memorial o fenômeno estético, tão bem explorado por Greimas em Da imperfeição (2002). O semioticista mostra, conforme comentamos, como a experiência estésica rompe a vida representada, operando uma mudança de isotopias, e estabelece uma relação sensorial entre sujeito e objeto.

É o que encontramos em Arrigucci, que apresenta as "imagens" que se alternavam em sua vida de menino: as cidades e a roça. Para recriá-las discursivamente e, assim, promover sua alternância no texto, investe numa forte densidade semântica, dada pela figurativização. Um universo sensorial, e principalmente visual - de claros e escuros - , apresenta-se para o leitor. São Paulo, cidade "cinza", constrasta com o Rio, repleto de "luz". O cromatismo encontra correspondência nos estados de alma do menino: se a ausência de luz pode ser ameaçadora, sua presença provoca o "maravilhamento". O impacto do encontro com as grandes cidades sobre a criança é forte, assim como sobre o sujeito da enunciação, o que se revela principalmente pela descrição muito breve feita das duas metrópoles: privilegiam-se os aspectos sensoriais que parecem concentrar o sentido dado a elas. A metonímia que descreve o Rio ("Rio era então o mar"), por exemplo, intensifica o choque, por meio do uso não-corriqueiro da linguagem e também por apresentar a cidade de maneira tão condensada. Cabe ao enunciatário desdobrar os sentidos aí investidos, desacelerando o impacto sensível causado pela figura de linguagem para chegar à compreensão. Ao encontro com as duas metrópoles opõe-se a vida cotidiana de cidade pequena, a que gera conforto, mas não "alumbramentos". A rotina, no caso das "imagens na roça", é nesse trecho construída pela enumeração, com sua forma redundante. Diversos elementos próprios à linguagem literária podem, então, ser reconhecidos em Arrigucci; a experiência da estesia deixa de pertencer apenas ao ator biografado ou ainda ao narrador recordador para ser compartilhada pelo sujeito da enunciação. 
O Rio era então o mar e a cidade grande, o maravilhamento da luz, em contraste com uma São Paulo cinzenta e meio ameaçadora, mal percebida de passagem pelos quartos de hotel - sobretudo do City Hotel daquele tempo - ou no rebuliço assustador das ruas. Essas imagens se alternavam, em minha vida de menino, com as da roça, do mato e dos rios, do Campo Triste, das caçadas e pescarias, das fazendas de colonos que eu visitava muitas vezes com meu pai, no atendimento aos chamados dos doentes (ARRIGUCCI JR., 1990a, p. 1).

O aspecto sensorial promove uma forma específica de verdade. Para Parret, assim como o sentimento de prazer é sempre um bem, a sensação a ele associada é sempre verdadeira, no sentido de que ela se estabelece como critério de verdade, pois "[...] ela é aquilo por meio do que existe a verdade para nós. Ela é o acesso à realidade" (2006, p. 139; tradução nossa) ${ }^{66}$. O "real" é, então, o que faz sentir, é ele também corporal. A sensação, consequentemente, encontra-se no choque dos corpos: no contato. Partilhada por meio da palavra, reconstruída na figuratividade, a sensação se torna então uma forma de acesso à verdade bastante poderosa. Enunciador e enunciatário creem na verdade das sensações que experimentam por meio do texto, sem precisar de um referente externo que as comprove.

Logo, a incorporação do prazer no texto torna possível outra forma de relação entre enunciador e enunciatário, baseada na partilha daquilo que é da ordem do sensível. O texto é corpo que entra em contato com outro corpo sensível, antes de apelar para aspectos inteligíveis. Entretanto, é preciso ressaltar que a entrada do prazer nos memoriais é realizada de maneira tímida, já que sua recriação discursiva é localizada, pode ser depreendida de algumas passagens espaçadas. Ainda assim sua presença é relevante: indica que o memorial impõe em seu contrato veridictório que o sujeito deve mostrar-se como alguém afetado sensivelmente por seu trabalho para que seja bem avaliado. Isso é também bastante revelador da esfera de circulação da qual faz parte o memorial, o meio acadêmico brasileiro. Seria uma exigência atual do meio acadêmico no Brasil construir o simulacro do cientista, professor e intelectual como alguém que sente prazer em realizar seu trabalho?

O segundo aspecto que merece ser comentado com relação às mudanças no éthos do memorialista é a ênfase que ganhou a construção do

66 “[...] elle est ce par quoi II y a pour nous vérité. C'est-à-dire accès à la réalité”. 
efeito de individualidade. $O$ éthos depreendido dos memoriais revela um sujeito singular, uma vez que cada memorialista passa a diferenciar-se dos demais conforme o tom asséptico, dominantemente voltado aos efeitos de objetividade e de neutralidade, vai sendo enfraquecido, o que se nota mais nas páginas iniciais ou finais dos textos.

Ao compararmos os éthe que podemos depreender dos memoriais do modelo 1, encontramos uma grande semelhança em sua configuração, o que indica que as coerções genéricas se avolumam em relação ao estilo autoral. É diferente do que ocorre com os memoriais do modelo 2. O confronto entre os diversos textos revela uma diferenciação maior entre os éthe depreendidos. Há no modelo 2 uma flexibilização do gênero, que favore o estilo de autor. Existem, porém, limites para essa flexibilização. Não foi abandonada a imagem de eficiência, de competência institucional, mas agrega-se a ela a marca da individualidade, própria a gêneros mais flexíveis que possibilitam a emergência de um estilo autoral. A leitura dos memoriais produzidos nos últimos anos parece revelar que o novo contrato veridictório estabelece que o efeito de individuação, de mostrar-se diferente dos demais, é algo desejável para que o enunciador seja sancionado de forma positiva. Se o sujeito é único, ele pode tornar-se também imprescindível.

A diversificação dos textos é que nos permite fazer tais constatações. Ela, com certeza, está expressa naquilo que o sujeito diz de si. Neves fala de sua independência (poder-não-ser) em relação à comunidade arqueológica brasileira, algo que se repete ao longo de todo o texto. Tatit qualifica suas propostas de estudo como "loucura", algo que está fora das normas, dos padrões. Ursi menciona a surpresa despertada por seu trabalho, ou seja, seu caráter imprevisível, não ordinário:

A existência de ambos sempre me pareceu prova inconteste de que era possível fazer ciência de qualidade no Brasil. Mas percebi logo que, no meu caso, isto só seria possível se eu observasse estritamente um preceito: manter-me absolutamente independente da comunidade arqueológica brasileira (NEVES, 2007, p. 8).

Se hoje tudo isso parece loucura, na época também parecia (TATIT, 2002, p. 19). 
A repercussão foi muito boa e enviei o arquivo com a atividade para vários professores. Também apresentei a atividade em meu último seminário no L.A.M.. Lembro-me de que muitos ficaram surpresos com o tema, pois o esperado seria uma apresentação sobre o trabalho desenvolvido em Curitiba (URSI, 2007, p. 15).

Aquilo que verificamos no "dito" confirma-se no "dizer". A diferença entre os textos aparece já em sua organização. Se tomarmos o sumário dos memoriais do modelo 1 , encontraremos tópicos bem parecidos de um texto para o outro, enquanto nos memoriais do modelo 2 isso varia mais.

Embora a ordem cronológica quase sempre prevaleça, o memorial pode ser dividido e subdividido de maneiras diversas. É possível nomear os tópicos levando em conta os lugares, as cidades ou as instituições por onde o candidato passou: "I. Montes Claros. Família. Primário. Ginásio"; "2. Belo Horizonte. Científico. Clássico", etc. (LAFETÁ, 1999). Outra possibilidade é organizar o texto de acordo com os diferentes papéis assumidos pelo candidato ao longo da vida: estudante ("Formação"), professor ("Cursos ministrados"), pesquisador ("Publicações"), entre outros. Há aqueles que preferem ainda outras formas de divisão, que levam em conta mudanças importantes: "Antes de Abidjan”, "Em Abidjan”, "Depois de Abidjan”, para a professora Margarida Petter, que viveu 6 anos na Costa do Marfim, tornando-se uma linguista especializada em línguas africanas: "A experiência africana foi definitiva e exemplar" (2008, p. 13). A liberdade maior na organização dos textos faz emergir sujeitos singularizados, ou seja, projeta um estilo autoral, a ser confirmado em outras obras dos mesmos autores.

Os nomes escolhidos para cada uma das partes já revelam posições diferentes com relação ao passado e com a vida em geral. A parte dedicada propriamente à narrativa da trajetória intelectual pode ser chamada de Histórico, Diário, Memória, Percurso, Introdução, Relato(s), Perfil profissional, Trajetória de vida, Apresentação, Parte 1, entre outros. Geralmente, o "Diário" possui um tom mais confessional e íntimo; já o tom do "Perfil Intelectual" é o da ciência; o do "Relato" pode ser mais jornalístico; etc. Assim, há memorialistas saudosos, grandiloquentes, assépticos, debochados, contidos, derramados, irônicos. Em Angyalossy, reconhecemos certo saudosismo, o passado é 
reconstruído como período repleto de aromas e cores, como vimos. Já em Neves as ironias e as críticas ajudam a compor um tom mais ácido.

No que se refere à Antropologia Biológica Pré-Histórica, meus esforços, no início, concentraram-se na introdução no país da Nova Antropologia Física, com uma visão populacional e não tipológica da variabilidade humana, mesmo a do passado. A Antropologia Biológica pré-histórica praticada, à época, no Brasil, remetia-se ainda às velhas escolas raciológicas e tipológicas européias do século XIX. Media-se primeiro para pensar depois (na melhor das hipóteses) (NEVES, 2007, p. 7: grifos nossos).

Essa mesma diversidade é encontrada na edição dos textos. Embora não seja intenção deste trabalho analisar a parte gráfica, é inegável que ela corrobora nossas afirmações. É possível variar a escolha de fontes, o espaçamento, a configuração da página, o tamanho dos títulos e subtítulos, entre outros recursos. Com relação às capas, notamos que as de cor preta, vinho ou azul, com letras douradas ou prateadas, remetendo a um éthos mais impassível, a um tom de voz mais solene e a um corpo rígido, deu lugar a algumas outras possibilidades:

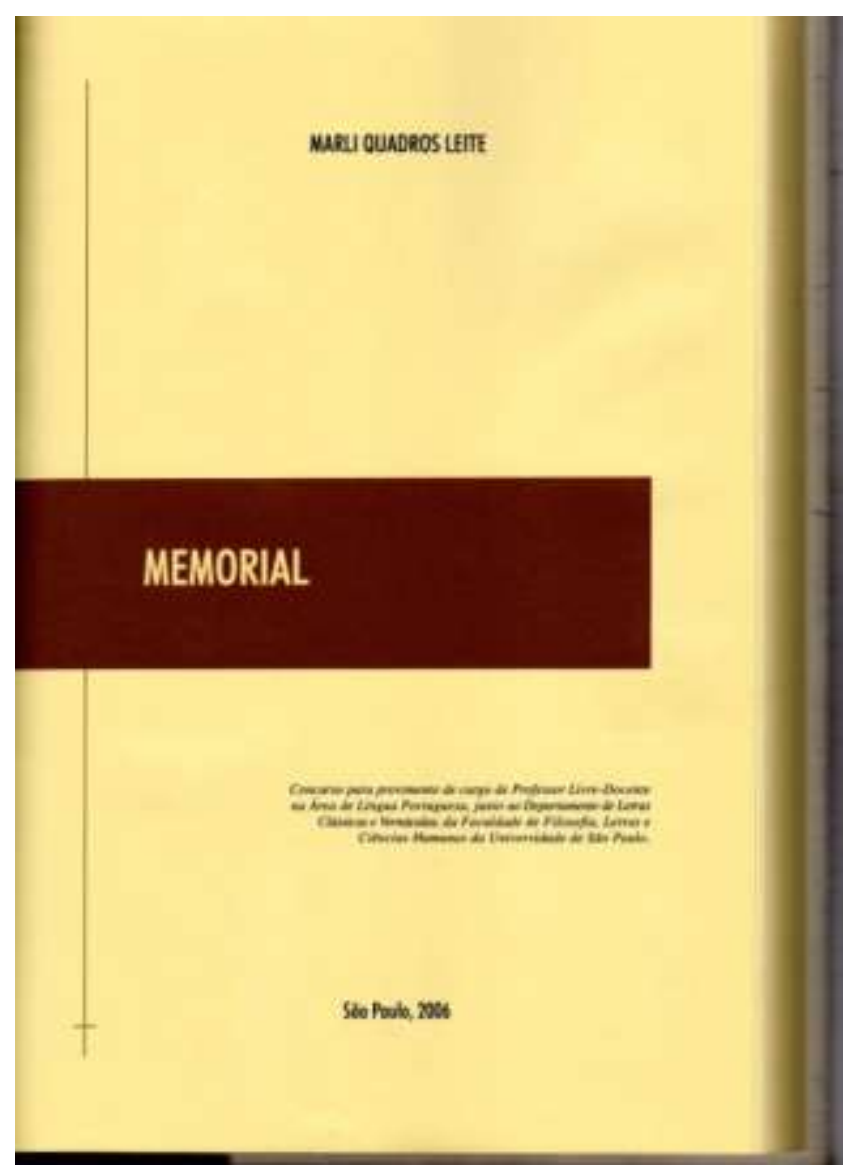


Encontramos variados tipos de papel compondo a capa, o que produz diferentes impressões táteis para o leitor. Além disso, é possível inserir cores, letras em fontes pouco usuais, ilustrações, formas geométricas. A capa do memorial de Quadros (2006) exemplifica bem nossas afirmações.

Nem tudo, no entanto, é diferença. A maior parte das capas exibe as mesmas informações distribuídas na página sempre de forma igual. Na parte de cima, centralizado, encontramos o nome do autor. No meio da página, o título: "Memorial" ou "Memorial acadêmico". Na metade de baixo, à direita, as informações sobre o concurso: "apresentado ao Departamento de Linguística para a obtenção do título de livre-docente na área de Linguística Africana", por exemplo. Encerram a página, a cidade e o ano de realização do concurso, centralizados. Conforme mostraremos no capítulo final, a flexibilização do memorial é bem menor do a que encontramos em obras literárias. Se o ator da enunciação deve mostrar que é único, constituindo-se como efeito de individualidade, não pode deixar de enfatizar que corresponde ao que se espera de um professor-pesquisador, adequando-se a certos padrões. Inclusive, o próprio efeito de individualidade deve ser entendido no trato com as coerções do gênero.

\section{CONSIDERAÇÕES FINAIS: O MEMORIAL ACADÊMICO}

Ao olhar em direção ao passado, o narrador seleciona, filtra, escolhe: a vida narrada pode, então, assumir múltiplos desenhos. Ela pode ser apresentada como o encadeamento de fatos mais planejados. Assim, o sujeito lembrado é mostrado como aquele que sempre teve objetivos claros, que sempre gostou de literatura e de línguas (no caso das Letras) ou que desde pequeno colecionava insetos (o biólogo). Esse é um extremo do que se poderia imaginar encontrar nos memoriais. $\mathrm{O}$ outro, mais raro, é a vida incorporada ao texto como sucessão de acontecimentos inesperados e imprevistos que abalam o sujeito. Cada novo evento faz com que mude de direção, restabeleça objetivos, prioridades, redimensione desejos. 
Numa ponta, está, então, um tipo de enunciado que prioriza as continuidades, aquilo que permaneceu através dos tempos, subsistindo à sua ação corrosiva. O sujeito do narrado é aquele que sabe o que quer desde o início, conseguindo realizar seu "projeto de vida". Na outra, temos aquele que prioriza descontinuidades: mudanças, esquecimentos, interrupções, lapsos. Nada do que é planejado ocorre plenamente. O sujeito do narrado enfrenta uma série de dificuldades, consegue superar algumas ou todas, aproximandose, em certos casos, da figura do herói. O passado pode mostrar-se como um período de grandes feitos.

O que pudemos observar, no entanto, é que a maior parte dos memoriais oscila entre representar continuidades e descontinuidades, para evitar o risco de cair numa vida absolutamente maçante e sem méritos, pois sem desafios, ou num viver desgovernado, desprovido de qualquer sentido. Realizar apenas uma das opções não parece desejável em um concurso. Assim, os estilos de vida representados, por mais diversificados que sejam, submetem-se ao gênero institucional, elaborado para um concurso. Daí os memoriais ficarem num ir e vir entre esses dois extremos, com a dominância da organização mais contínua, ou seja, de uma vida mais guiada pelo exercício.

A dominância do exercício está relacionada ainda ao olhar retrospectivo que o narrador lança para seu percurso intelectual e acadêmico. Como bom cientista ou acadêmico, ele procura encontrar as regularidades escondidas atrás da aparente desordem. Daí o memorial transformar grandes eventos em exercício, diferentemente do que encontramos nos poemas de Manuel Bandeira. Os diversos acontecimentos da vida privada e, principalmente, pública - as viagens, as descobertas, os encontros com novos autores, os resultados ruins nos exames, etc. - são geralmente explicados por uma lógica implicativa, que resgata a inteligibilidade impossível do acontecimento. A vida nos memoriais é vista, predominantemente, como exercício.

A busca de uma identidade (autoconhecimento) do professorpesquisador, por parte daquele que narra, parece estar diretamente ligada a essa maneira de escrever a vida. A identidade é produzida na maior parte dos textos como aquilo que é recorrência, como os traços que se mantêm ao longo do percurso, das mudanças de rumo e de todas as variações. 
Estabelece-se o passado como objeto a ser observado com alguma "imparcialidade", objeto destacado do presente da narração. Não é feito, predominantemente, para o sentir, mas para explicar e ser explicado. A memória e o memorialista se constroem, então, como seres cuja existência parece anteceder a relação que os instaura na escritura das memórias. Afirmamos que "parece anteceder", pois como afirma Geninasca:

O Discurso social tende a subsidiar a ilusão referencial: mas o objeto em si, dotado de uma existência autônoma que ele instaura, é em si mesmo apenas um efeito de sentido ligado à atualização de tal ou tal procedimento discursivo (1997, p. 201; tradução nossa) ${ }^{67}$.

A realidade da memória fundamenta-se em todos os recursos que contribuem para a criação de um efeito de referência. Vale lembrar que o texto é permeado pela indicação da documentação que o acompanha, pelo nome de pessoas e lugares, pelas datas e mesmo por alguns marcos históricos. Todos esses elementos ancoram o que se diz num discurso partilhado e social a respeito do mundo. $O$ detalhamento contribui para a ilusão de que nada escapou. Além disso, o memorial é assinado e datado, o que é reconhecido como a "garantia" de que se diz a verdade. $O$ enunciador compromete-se diante da comunidade científica, assumindo a responsabilidade pelo que é dito.

A realidade do memorialista fundamenta-se, em primeiro lugar, no efeito de identidade entre ator do narrado, narrador e enunciador. A assinatura, o nome na capa, a data, o nome da instituição, os dados pessoais, a lista de obras publicadas, entre outros elementos, confirmam a "existência" das três instâncias. O próprio gênero memorial cria como expectativa e, assim, efeito de sentido uma pessoa "real" que narra seu percurso acadêmico.

Afinal, como já dissemos, estamos tratando de um gênero escrito para um concurso, com a finalidade de convencer a banca examinadora e a comunidade científica em geral das competências do candidato. Não seria possível mostrar as competências adquiridas em uma vida e ao mesmo tempo

67 "Le Discours social tend à accréditer l'illusion référentielle: mais l'objet en soi, doté d'une existence autonome qu'il pose, n'est en lui même qu'un effet de sens lié à l'actualisation de telle ou telle procédure discursive". 
afirmar que tudo não passa de uma construção discursiva. Daí a necessidade de produzir o efeito de realidade nesse gênero.

Essas competências do professor-pesquisador podem ser resgatadas no que diz o memorial. Ele traz as publicações, as etapas vencidas da carreira, as reflexões científicas, os cursos ministrados. Nesse sentido, o memorial funciona como a própria "prova" dessas competências: "A trajetória aqui narrada atesta um processo de amadurecimento em diversos âmbitos", afirma Negrão (2004, p. 95). Mas as competências também são reveladas por meio da escritura: o fazer, a performance. O modo de dizer revela um modo de ser e de estar no mundo: o éthos. No caso dos memoriais, estamos quase sempre diante de um éthos marcado pela paixão da emulação, em menor ou maior grau, ainda que existam momentos de ironia, deboche ou inadequação em relação ao percurso do ator do narrado ou à própria realização do memorial. Como mostra Discini:

[...] temos, na emulação, um sujeito emparelhado àquele actante do nível narrativo, o sujeito em conjunção com o objeto de valor; um sujeito bem sucedido, sancionado positivamente, articulado a uma performance a contento, relativa a certa manipulação sofrida $(2010$, p. 20$)$.

Retomando Greimas e Fontanille (1993), a autora afirma que "[...] 0 julgamento ético transforma um saber-fazer e um poder-fazer do sujeito em 'mérito'” (p. 21). O mérito é apreciado no conjunto de um percurso e não apenas no resultado obtido:

[...] não se esgota na realização da performance, não é reconstruído por pressuposição a partir da competência; aparece como "excedente modal", caracterizando o ser do sujeito aquém ou além da competência requerida pela realização do programa (GREIMAS; FONTANILLE, 1993, p.1 75).

A análise dos memoriais possibilitou verificar as mudanças na constituição do éthos e no próprio contrato veridictório, no que concerne a duas grandes totalidades articuladas, por sua vez, a décadas definidas (modelo 1: década de 70 para a Faculdade de Letras e décadas de 70 e 80 para o Instituto de Biociências; modelo 2: décadas de 80, 90 e 2000 para a Faculdade de Letras e décadas de 90 e 2000 para o Instituto de Biociências). O uso das 
debreagens enunciativas de pessoa, tempo e espaço nos memoriais praticados na Faculdade de Letras a partir dos anos 80 e no Instituto de Biociências a partir dos anos 90, em oposição à enunciva, própria do outro modelo, indica uma transformação bastante relevante. Como já dissemos, a subjetivação aumenta. Além disso, há uma flexibilização do registro e ainda um grande emprego de elementos que revelam um éthos mais passionalizado, como o recorrente uso das interjeições, do léxico de caráter mais afetivo e sensorial, entre outros elementos. Notamos ao longo da análise a busca por fortalecer o efeito de singularidade do éthos nos memoriais do modelo 2 e ainda por tornálo mais sensibilizado, mostrando a relação de prazer que liga o memorialista a seu ofício.

Essas diferenças entre os dois modelos sugerem que houve mudanças na vida acadêmica, no que é ser professor-pesquisador. Os prazeres individuais (querer) começam a ganhar quase o mesmo destaque dos projetos coletivos (dever). A inovação, que nos textos do modelo 1 aparece principalmente no narrado, passa, no modelo 2, a participar da construção do simulacro do professor-pesquisador, que precisa mostrar sua singularidade no meio acadêmico. Assim, reconhecemos no discurso acadêmico algumas características que parecem ser próprias do nosso tempo.

A incorporação de uma linguagem mais sensorial e afetiva e de uma série de outros elementos que contribuem para criar uma imagem de enunciador menos neutro não se realiza, porém, exatamente da mesma forma nos textos da Faculdade de Letras e nos do Instituto de Biociências. Embora não seja nossa intenção diferenciar, neste trabalho, os memoriais produzidos nas duas áreas, pudemos observar, na Faculdade de Letras, a aproximação em relação a uma linguagem mais literária e, no Instituto de Biociências, um emprego mais emotivo ou mais próximo do humor.

Podemos dizer que os memoriais mais recentes procuram restabelecer, no domínio universitário, entre teses e relatórios, um equilíbrio entre o sensível e o inteligível. Entretanto, não se pode esquecer que o memorial acadêmico trata essencialmente da vida profissional do "autor" e que, dentre os diferentes papéis temáticos assumidos pelo enunciador (de pai, de artista, de atleta, entre outros), destaca-se o de professor-pesquisador. É o acadêmico que observa sua vida passada, mais especificamente o acadêmico que enfrenta um 
concurso. Ele está imerso no tempo presente quando se lembra ou se esquece de alguma coisa. Logo, a memória é recriada a partir do que ele experimenta no seu presente. E seu presente, nesse caso, é a situação de prova no contexto universitário. $\mathrm{O}$ enunciador dos memoriais assume, normalmente, o ponto de vista institucional, procurando tornar um pouco mais inteligível o que foi vivido como acontecimento.

Todas essas coerções não significam que não possa haver memoriais que rompam parcialmente o contrato de veridicção estabelecido, mas até o momento não deparamos com nenhum que chegasse ao extremo de uma subversão total dos modelos de previsibilidade instaurados pelo gênero, tornando-se assim um "acontecimento", no que diz respeito a esses modelos. 


\section{CAPÍtULO 4}

\section{ENTRE MEMÓRIAS E GÊNEROS}

Tinha aprendido sem esforço o inglês, o francês, o português, o latim. Suspeito, entretanto, que não era muito capaz de pensar. Pensar é esquecer diferenças, é generalizar, abstrair. No abarrotado mundo de Funes não havia senão pormenores, quase imediatos.

Jorge Luis Borges

"Funes, o Memorioso"

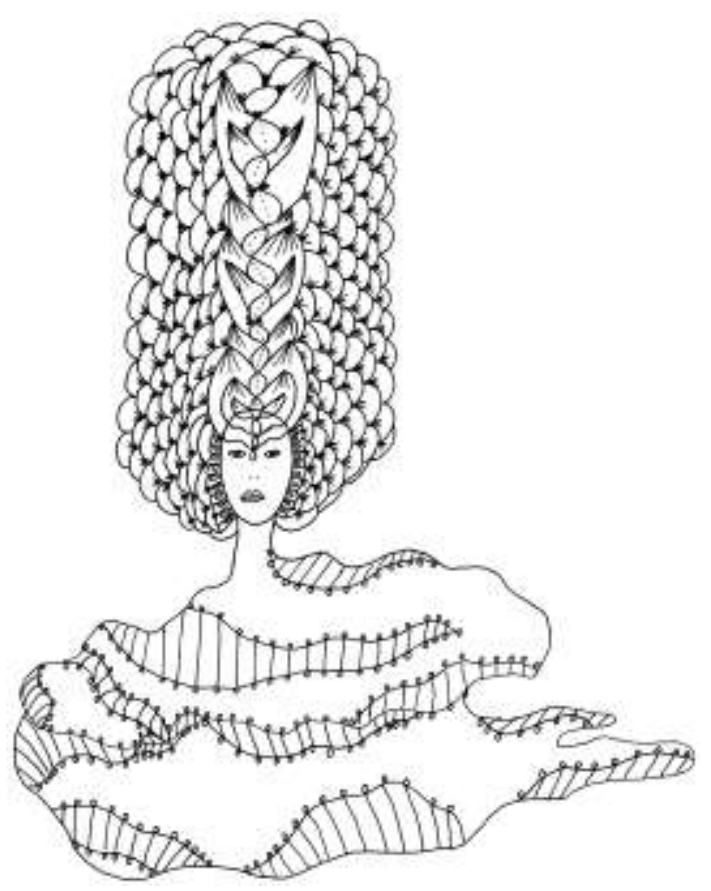


Nos capítulos anteriores, examinamos diferentes gêneros autobiográficos, buscando compreender o funcionamento de cada um e ainda as especificidades de cada texto. Essa análise constitui a base para as reflexões que aqui apresentamos a respeito do discurso autobiográfico em geral. Greimas e Courtés explicam a noção de generalização própria ao procedimento hipotético-dedutivo:

De acordo com o procedimento hipotético-dedutivo a que nos propomos, a generalização deve tomar a forma de construção de um modelo hierarquicamente superior e mais extenso que o fenômeno reconhecido, do qual este não é senão uma variável. [...] O modelo assim construído poderá ser, a seguir, infirmado, confirmado ou modificado [...]. As categorias utilizadas para a construção de tais modelos serão ditas gerais por oposição às categorias universais (2008, p. 227).

É em busca de algumas dessas categorias gerais que partimos agora, com o objetivo de aumentar a inteligibilidade dos discursos autobiográficos, materializados nos exemplares escolhidos em meio à produção brasileira, tanto literária quanto acadêmica. Para ilustrar nossas observações, traremos, de forma comparativa, outras obras autobiográficas, além das analisadas até 0 momento.

\section{OS NÍVEIS DO DISCURSO AUTOBIOGRÁFICO}

As autobiografias literárias em prosa, os poemas de caráter autobiográfico e os memoriais acadêmicos reconstroem na linguagem um passado. Esse passado, mesmo no interior de cada obra, não pode ser visto como único, pois ele é percebido pelos diversos "eus" que com ele se relacionam. Para tratar com maior precisão dessas questões, mostrou-se necessário distinguir diferentes níveis na organização do discurso autobiográfico.

Podemos estabelecer como um primeiro nível aquele que engloba o protagonista ou ator do narrado e o mundo, vistos a partir da maneira como interagem. Esse primeiro nível diz respeito, portanto, à construção do 
simulacro da vida biografada. É nessa etapa que o discurso recupera também os momentos de memorização, ou seja, quando a vida vivida se torna vida lembrada. Podemos formular esta síntese concernente a uma primeira interação:

- Protagonista (ator do narrado) e mundo

Não se pode esquecer, no entanto, que o vivido é apresentado nas obras autobiográficas como memória de alguém: há um narrador que lembra e que relata a vida de outro eu no passado. Logo, é importante observar o modo como esse narrador, no aqui e agora da narração, relaciona-se com sua memória narrada. A distância entre o narrador e sua memória pode ser mostrada como maior ou menor, assim como a separação entre o sujeito do presente e aquele do passado: numa extremidade está a imersão total na memória; na outra, a cisão total. Temos então outro par sintetizador:

- narrador e memória

Tudo isso aparece para o enunciatário como orquestrado pelo enunciador. Além disso, o efeito nas obras autobiográficas é de que a vida relatada é a vida do enunciador (a "minha vida"). Não podemos esquecer, entretanto, que o enunciatário participa da construção do sentido do discursoenunciado autobiográfico:

[...] o enunciatário não é apenas destinatário da comunicação, mas também sujeito produtor do discurso, por ser a "leitura" um ato de linguagem (ato de significar) da mesma maneira que a produção do discurso propriamente dito. O termo "sujeito da enunciação", empregado frequentemente como sinônimo de enunciador, cobre de fato as duas posições actanciais de enunciador e de enunciatário (GREMAS; COURTÉS, 2008, p. 171).

Conforme afirmamos anteriormente, a linguagem faz-ser no presente a imagem de um passado, para que a memória seja presentificada. Desse modo, a memória aparece àquele que se recorda como uma imagem-simulacro do passado; não se pode ignorar, porém, que ela é uma experiência também do 
tempo presente. É ativada, filtrada, selecionada e recriada a partir da experiência presente e ainda é sentida no presente. Mais do que simplesmente mostrar a maneira como a vida foi vivida, os gêneros autobiográficos desvelam a visão do enunciador sobre a vida contada. Para compreender as posições assumidas, é preciso levar em conta então o modo como a memória é construída no texto, pois é ele que nos dará pistas a respeito da enunciação autobiográfica. Marcada por uma intencionalidade, a enunciação é compreendida como "uma 'visada do mundo', como uma relação orientada, transitiva, graças à qual o sujeito constrói o mundo enquanto objeto ao mesmo tempo em que constrói a si próprio" (GREMAS; COURTÉS, 2008, p. 168). Propomos, portanto, um terceiro par sintetizador:

- enunciador e enunciado

O esquema a seguir apresenta os níveis de análise pertinentes na investigação do discurso autobiográfico ${ }^{68}$ :

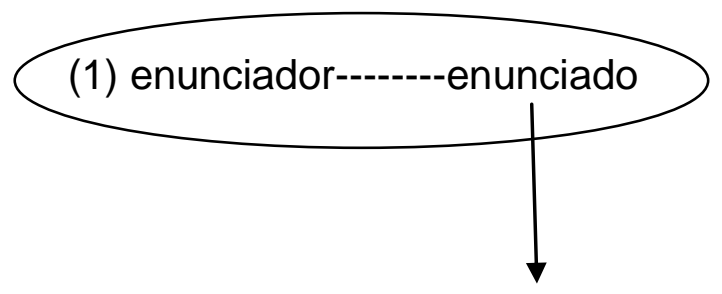

(2) narrador-------memória

(3) protagonista-------mundo

\footnotetext{
${ }^{68} \mathrm{~A}$ linha pontilhada indica relações no mesmo nível e a seta indica a passagem de um nível a
} outro. 
É comum que o nível 3 seja desdobrado, instituindo um nível 3', uma vez que o narrador pode lembrar-se de um momento passado em que se lembrava de um momento ainda anterior, criando diversos tempos passados (anterioridades em relação ao momento em que a memória é ativada), assim como diversos tempos presentes (concomitâncias em relação ao momento em que a memória é ativada).

(1) enunciador-------enunciado

(2) narrador memória

(3) protagonistamemória

(3') protagonista-mundo

Quando o narrador de Baú de ossos, num instante coincidente ao marco "Há bem pouco tempo" - logo, não concomitante, sintaticamente, ao agora da narração - vê o torreão da delegacia, lembra-se de Luís Felipe Vieira Souto. O inusitado da recordação o impele a reconstituir o percurso realizado por sua memória. A rememoração do passado no passado revela que a memória nessa obra é vista como algo dinâmico, que se faz ao longo da vida. Longe de ser dada como acervo fechado de onde se extraem lembranças estanques, ela se apresenta como uma metamemória: 
Às vezes perturbada nos seus encadeamentos, a associação de idéias dói - como sonda metálica mal conduzida fazendo fausse route nos canais do corpo. Há bem pouco tempo tive essa experiência. Chegando, um dia, pela Rua do Catete, à esquina de Pedro Américo, olhei o torreão (hoje derrubado) da Delegacia de Polícia. Ele se destacava sobre a parede clara do arranha-céu, no fundo. Olhando a parede, da representação da parede branca destacou-se com dificuldade, num retumbar de palpitações, numa agonia de tonteira, a lembrança da figura defunta de Luís Felipe Vieira Souto. A mim mesmo espantou a associação que se me afigurou estapafúrdia. Não era. Eu estava seguindo um curso de pensamento que, de tanto repetido, fezme tomar nele o caminho mais curto e pulei da parede, imediatamente, à sombra, ao vulto, a que deveria chegar mediatamente segundo encadeamento regido pelo hábito (BO, p. 293-294).

\section{AS IDENTIDADES DO DISCURSO AUTOBIOGRÁFICO: UMA QUESTÃO DE GRAUS}

O discurso autobiográfico define-se essencialmente por meio do estabelecimento de três efeitos de identidade ${ }^{69}$ :

- (a) protagonista e enunciador;

- (b) narrador e protagonista;

- (c) enunciador e narrador.

Em quase todo o corpus deste trabalho, pudemos observar a criação desses efeitos de identidade dados nos enunciados por meio de menor ou maior força, e ainda por meio de diferentes recursos da sintaxe e da semântica discursivas. Na prosa, seja ela literária, seja acadêmica, notamos que o efeito de identidade entre o protagonista e o enunciador é produzido essencialmente pela repetição no interior da obra do antropônimo que concretiza o enunciador implícito, como já havia observado Lejeune (1996), ao propor a noção de pacto autobiográfico.

Pedro Nava, Pedro ou Pedrinho é o protagonista das Memórias, mas Pedro Nava é também o seu autor, nestas reflexões tratado como projeção

${ }^{69}$ Essas identidades são a marca mais relevante do discurso autobiográfico. Incluem-se nesse discurso os diários, as cartas, os currículos, apenas para ficar no domínio da semiótica verbal, pois seria pertinente verificar o que ocorre, por exemplo, na pintura e na fotografia, com os autorretratos, ou ainda nas semióticas sincréticas, como é o caso dos blogs. 
discursiva. Uma série de outros recursos pode fortalecer essa identidade ou diluí-la. A apresentação da genealogia do ator do narrado, o relato dos momentos em que ele escreve ou publica obras que atribuímos a Pedro Nava (enunciador), a citação de documentos que se reportam à vida do ator do narrado corroboram o efeito de identidade. Em Chove sobre a minha infância (2000), do paranaense Miguel Sanches Neto, são apresentados: o jornal com a notícia da morte do pai, diversas fotografias de família e uma carta da irmã comentando o manuscrito da obra. No caso de Sanches Neto, a incorporação desses enunciados ajuda ainda a criar o simulacro de sinceridade, que caracteriza o narrador nessa obra.

\section{Querido irmão}

Li seu livro emocionada não só por ter participado dos acontecimentos mas porque vejo como a leitura te livrou de um destino que insistia em ficar grudado em nossa família.

Agora compreendo melhor o que se passava em sua cabeça, suas angústias e mesmo este profundo sentimento de orfandade, que definiu sua personalidade. [...]

Durante anos eu guardei um profundo segredo. Mas não há mais sentido em manter você longe da realidade. [...] A verdade é que você não se lembra do pai, ele nos chegou apenas pela única foto e por aquilo que a mãe contava. A mãe sempre foi uma contadora de histórias e soube pôr a ficção na frente do real. Ela não queria que você se revoltasse ao descobrir o lado feio do pai. [...]

No último ano de vida, por estar desesperado, o pai se envolveu com roubo de café nas fazendas da região. Foi assim que ele conseguiu o dinheiro para fazer a maldita viagem em que morreu. [...]

Um beijo de sua irmã,

\section{Carmen Sanches}

(SANCHES, 2000, p. 243-249)

Os elementos mencionados criam um efeito de correspondência com adequação máxima entre o que seria a vida "real" do enunciador e a vida narrada. A relação é construída da seguinte forma: se o efeito de correspondência entre essas duas vidas é dado por um grau máximo de adequação, o protagonista e o enunciador são aproximados. É preciso dizer, no entanto, que a literatura pode utilizar os mesmos procedimentos em obras não autobiográficas. 
Nas vastas Memórias de Pedro Nava, todos os elementos que mencionamos são amplamente explorados, assim como nos memoriais acadêmicos. Permeiam ainda estes últimos as publicações do ator do narrado, sempre mencionadas dentro dos padrões de referência bibliográfica assumidos pela comunidade acadêmica como necessários e suficientes em termos de informação.

Poderíamos imaginar que essa maneira mais "referencial" de construir o passado é própria da prosa autobiográfica, mas Infância, de Graciliano Ramos, contradiz em parte essas afirmações. Encontramos apenas uma única ocorrência do nome "Ramos", empregado para nomear a empresa criada em sociedade pelo pai. Não há fotos e outros documentos que produzam essa espécie de "correspondência" entre a vida narrada e a vida vivida pelo enunciador. Mesmo assim, o leitor consegue estabelecer a relação de identidade, reconhecendo a obra como autobiográfica.

Em Bandeira não encontramos o nome do autor no interior dos quatro poemas selecionados. No entanto, a recorrência de certos antropônimos e topônimos (a Rua da União, a Rosa, Totônio Rodrigues, Recife, etc.), além da repetição de cenas figurativizadas ao longo da obra (a prosa na calçada, as brincadeiras de criança, etc.) como parte da vida do narrador e do ator do narrado, permite fazer a identificação entre $o$ ator do narrado e o enunciador graças à alusão intertextual. Trata-se de um modo singular de criar o discurso autobiográfico, que parece ser próprio da poesia de Bandeira e, muito provavelmente, da poesia em geral.

O efeito de identidade entre narrador e protagonista dá-se, geralmente, por meio do uso do pronome pessoal eu, empregado para designar o narrador e o ator do narrado. Há, então, duas debreagens enunciativas de pessoa, uma da enunciação e outra do enunciado. Reforça essa identificação o fato de o narrador mostrar-se como aquele que evoca seu passado, ou ainda que narra suas memórias ("minha vida"). Quanto mais afetado ele é pelo passado que emerge no presente, mais essa identidade parece intensificar-se, por meio de uma aproximação entre o eu da narração e o eu do narrado. Como vemos, a identidade desliza da sintaxe para a semântica e dela para uma tensividade mensurada em graus. Ecléa Bosi, ao retomar as críticas feitas por Maurice Halbwachs a Bergson, afirma: 
A lembrança é uma imagem construída pelos materiais que estão, agora, à nossa disposição, no conjunto de representações que povoam nossa consciência atual. Por mais nítida que nos pareça a lembrança de um fato antigo, ela não é a mesma imagem que experimentamos na infância, porque nós não somos os mesmos de então e porque nossa percepção alterou-se e, com ela, nossas idéias, nossos juízos de realidade e de valor. O simples fato de lembrar o passado, no presente, exclui a identidade entre as imagens de um e de outro, e propõe a sua diferença em termos de ponto de vista (2001, p. 55).

Nosso intuito não é entrar na discussão a respeito do que é a memória, mas buscar compreender sua representação discursiva nas obras estudadas; ainda assim a observação de Bosi nos dá algumas pistas a respeito da questão das identidades. O que observamos em Bandeira e em outras obras autobiográficas da literatura é o desejo de suprimir a distância entre os tempos. A escrita literária permite que se produza o efeito de que o adulto vê o que 0 menino via, há uma identificação momentânea de pontos de vista, o que reforça o efeito de identidade entre o narrador e o ator do narrado.

Nos versos de "Evocação do Recife", conforme mostramos, o espaço em branco deixado na página recupera a distância do sino que tocava à noite em relação ao lugar onde estava a criança, fazendo com que o narrador reviva essa mesma distância. É como se ele ocupasse outra vez o lugar em que esteve quando era um menino.

Produzem efeito semelhante as embreagens de espaço e de tempo que neutralizam a oposição entre o sistema enunciativo e o enuncivo. Quando aquele é empregado no lugar deste, o narrado invade a narração, na medida em que o passado impregna o presente.

Saio correndo pro quintal pra ver se os filhotes de sabiá estão protegidos no ninho. O sol me cega, passei a manhã toda dentro de casa, preciso fechar um pouco os olhos pra poder ir me acostumando com a claridade. Logo estou subindo no pé de abacate pra ver o ninho (SANCHES, 2000, p. 41-42).

Em Chove sobre a minha infância (SANCHES, 2000), esse procedimento recobre a maior parte do texto. Trata-se de um caso bastante 
peculiar na literatura brasileira. É como se o narrador e o protagonista ocupassem, quase em toda a obra, o mesmo centro dêitico, a partir de onde se estabelecem as relações espaçotemporais. Daí podermos afirmar que esses recursos concernentes ao tempo e ao espaço produzem também um efeito de proximidade relativo à pessoa.

Ao contrário do que encontramos nos gêneros autobiográficos provenientes da esfera literária, nos memoriais acadêmicos, procura-se, predominantemente, estabelecer certo distanciamento entre o narrador $\mathrm{e} o$ ator do narrado, além daquele produzido, em quase todo discurso autobiográfico, por meio do uso de sistemas temporais distintos (o narrador está num agora, enquanto o ator do narrado num então). Nos memoriais do modelo 1 - mais encontrados na Faculdade de Letras (FFLCH-USP) até o início dos anos 80 e no Instituto de Biociências (IB-USP) até início dos anos 90, no que se refere ao período estudado -, esse distanciamento é criado, sobretudo, pela sintaxe discursiva. Em relação à discursivização da pessoa, as embreagens enunciva da enunciação e enunciva do enunciado resultam num efeito de objetividade e de distanciamento que parecia, então, desejável à época:

Contratado em dezembro de 1960 para inaugurar na Universidade de São Paulo o ensino de Teoria da Literatura, o candidato se preparou desde logo em formar uma equipe, que pudesse continuar e desenvolver as atividades da disciplina recém-criada (CANDIDO, 1974, p. 21).

No modelo 2 - mais frequente na Faculdade de Letras (FFLCH-USP) a partir dos anos 80 e no Instituto de Biociências (IB-USP) a partir dos anos 90 -, encontramos, quanto à pessoa, as debreagens enunciativa da enunciação e enunciativa do enunciado que criam, na sintaxe discursiva, o efeito de identidade. No entanto, as fronteiras que separam o eu narrador e o eu narrado, ainda neste segundo modelo, são mantidas com mais ênfase do que no discurso autobiográfico literário. Há poucas embreagens de tempo ou espaço como as que substituem o sistema enuncivo pretérito pelo enunciativo, aproximando o passado do presente da narração. Além disso, os momentos em que as lembranças vêm tomar o presente são mais raros. Prevalece a apresentação do passado como algo cujo acabamento é anterior ao relato. $O$ 
narrador dos memoriais geralmente se mostra não como aquele que se recorda de seu passado, mas como quem pode analisá-lo, a partir de uma lógica implicativa. É como se o narrador relatasse fatos recolhidos não de sua própria memória - subjetiva, cheia de lacunas e incertezas -, mas de um discurso anterior já constituído como verdade ou ainda como realidade para a comunidade acadêmica. Contribui para a criação desse efeito o largo emprego de índices espaçotemporais com função de ancoragem. Além disso, o texto dos memoriais é costurado do início ao fim por indicações aos documentos que o acompanham:

Decidi fazer o trabalho final (Minimémoire) em Sociolinguística, sob a orientação da professora Simone Lafage. A monografia tinha por título "Profil sociolinguistique et réalisations linguistiques des élèves du CM2" (198/216) (PETTER, 2008, p. 15: grifos nossos).

No final do fragmento, somos remetidos à seguinte nota: "A partir dessa referência, os números entre parênteses correspondem à numeração das páginas das pastas de documentos e das publicações" (PETTER, 2008, p. 15).

É necessário enfatizar que esses elementos de ancoragem em dados do "mundo" também aparecem na literatura. Em A menina do sobrado, de Cyro dos Anjos, o passado é atravessado por datas, nomes de ruas e de pessoas, que ajudam a situar a vida biografada numa temporalidade mais amplamente circunstancializada:

A casa da rua Bernardo Guimarães - que me ligava a um passado arcaico e fora do eixo das minhas experiências de 1916 e 1923 incorporara, assim, outro elemento encantatório, uma força nova a atrair-me: as valsas de Chopin e sua pequena intérprete (ANJOS, 1994, p. 276).

E, a 21 de abril daquele ano de 31, Belo Horizonte, com a memória ainda fresca dos ditirambos que os tribunos aliancistas entoavam à democracia e à liberdade, presenciou, maliciosa, ao desfile dos legionários de Chico Campos (ANJOS, 1994, p. 413-414).

O narrador apresenta com riqueza de dados a história da cidade e a do país, que funcionam como referentes de sua própria história: "Fiz uma longa 
digressão. É tempo de mostrar que nexo existe entre a minha modesta biografia e esses acontecimentos da política mineira" (ANJOS, 1994, p. 414).

Falta tratar ainda do terceiro efeito de identidade: entre o narrador e o enunciador. Não é por acaso que deixamos para falar dele por último, uma vez que resulta das identidades anteriores, podendo ser fortalecido por embreagens de pessoa que colocam o narrador como o autor do livro. A assinatura que geralmente encerra os memoriais constitui um dos recursos que produz essa sobreposição de níveis. O leitor não pode dizer se quem assina os memoriais é o narrador ou o enunciador. Nas páginas que abrem as autobiografias literárias em prosa, encontramos muitas vezes esse mesmo recurso. É o que vemos na obra de José Lins do Rego (1987), que, como a de Graciliano, não oferece ao leitor uma imagem idílica da infância. Numa espécie de "prólogo", que antecede o relato da infância propriamente, o narrador/enunciador apresenta o seu "livro de memórias". Encerram essa parte as iniciais do "autor" - ou do narrador -, acompanhadas pelo local e pela data, que ancoram no tempo e no espaço, não o narrado, mas a própria narração.

Chamei de verdes anos os tempos da minha primeira infância. E em livros de memórias procurei reter tudo o que ainda me resta daquela "aurora" que para o poeta Casimiro fora a das saudades, dos campos floridos, das borboletas azuis. Em meu caso, as borboletas estiveram misturadas a tormentos de saúde, a ausência de mãe, a destemperos de sexo. [...] Fiz livro de memórias, com a matéria retida pela engrenagem que a natureza me deu. Pode ser que me escapa a legitimidade de um nome ou de uma data. Mas me ficou a realidade do acontecido como grão na terra. A sorte está em que a semente não apodreça na cova e que o fato não tenha o pobre brilho do fogo-fátuo. É tudo o que espero dos "verdes anos" que se foram no tempo, mas que ainda se fixam no escritor que tanto se alimentou de suas substâncias.

Rio, Janeiro de 1956.

(REGO, 1987, p. 1162)

Por conseguinte, os títulos e subtítulos que trazem figuras e temas relacionados à memória podem reforçar esses efeitos de identidade. A obra é, 
assim, lida como autobiográfica, ou seja, como realizando essas três identidades ${ }^{70}$. Alguns títulos que fazem parte da literatura brasileira confirmam nossas observações: Minhas recordações (REZENDE, 1944); Memórias (CAMPOS, 1947); Segredos da infância (MEYER, 1949); Meus verdes anos (REGO, 1987); Chove sobre minha infância (SANCHES, 2000). Os possessivos, bastante frequentes, enfatizam o vínculo entre o enunciador e a vida biografada.

Parece pertinente, portanto, não observar a questão das identidades nas obras autobiográficas como grandeza discreta, pois é possível que esse efeito seja mais acentuado ou menos em cada texto. Com relação ao efeito de identidade entre narrador e ator do narrado, observamos que ele oscila inclusive no interior de uma mesma obra. Há momentos em que o narrador se mostra como quem se lembra do que narra, sendo afetado pela memória, e há outros em que ele fabrica o passado como fato distante:

Volto, agora, ao Colégio, para anotar que ali já me encontrava em fins de 1910, aos quatro anos, segundo a data que se lê numa fotografia coletiva, tirada com as freiras. Mesclam-se as imagens, em célere desfile: o casarão com o mirante; o pátio de árvores imensas a cuja sombra a gente brincava durante o recreio; Soeur Blanche, pálida e esguia; Soeur Blandine, rechonchuda e risonha; a superiora de ares sobranceiros; o teatro em que fiz papel de borboleta, com enormes asas, a voltear em torno duma barrica... (ANJOS, 1994, p. 45).

Elencamos a seguir alguns recursos empregados para fortalecer (+) ou enfraquecer (-) as três formas de identidade.

\footnotetext{
${ }^{70}$ Isso ocorre apenas se a obra não possuir elementos que, ao longo da leitura, façam o enunciatário desconstruir os efeitos de identidade, sobretudo o que se dá entre enunciador e protagonista. Há muitos romances não autobiográficos que trazem em seus títulos figuras e temas relacionados à memória, como Memórias póstumas de Brás Cubas (2008), de Machado de Assis.
} 
(a) PROTAGONISTA (ATOR DO NARRADO) E ENUNCIADOR

\begin{tabular}{|l|l|}
\hline \multicolumn{1}{|c|}{+} & \multicolumn{1}{|c|}{-} \\
\hline $\begin{array}{l}\text { semelhança entre o nome do enunciador e } \\
\text { o do protagonista }\end{array}$ & $\begin{array}{l}\text { diferença entre o nome do enunciador e } \\
\text { o do protagonista }\end{array}$ \\
\hline $\begin{array}{l}\text { grande recorrência no narrado do nome do } \\
\text { protagonista (se for o mesmo que o do } \\
\text { enunciador) }\end{array}$ & $\begin{array}{l}\text { ausência ou pequena recorrência no } \\
\text { narrado do nome do protagonista (se for } \\
\text { o mesmo que o do enunciador) }\end{array}$ \\
\hline apresentação da genealogia & ausência da genealogia \\
\hline $\begin{array}{l}\text { relato da escritura de obras de autoria do } \\
\text { enunciador }\end{array}$ & $\begin{array}{l}\text { ausência do relato da escritura de obras } \\
\text { de autoria do enunciador }\end{array}$ \\
\hline $\begin{array}{l}\text { incorporação de documentos históricos } \\
\text { (fotos, artigos de jornal, etc.) }\end{array}$ & $\begin{array}{l}\text { ausência de documentos históricos } \\
\text { (fotos, artigos de jornal, etc.) }\end{array}$ \\
\hline $\begin{array}{l}\text { grande repetição de nomes de pessoas, } \\
\text { lugares e de outros elementos figurativos } \\
\text { em obras do mesmo autor }\end{array}$ & $\begin{array}{l}\text { ausência ou pequena repetição de } \\
\text { nomes de pessoas, lugares e de outros } \\
\text { elementos figurativos em obras do } \\
\text { mesmo autor }\end{array}$ \\
\hline
\end{tabular}

(b) NARRADOR E PROTAGONISTA

\begin{tabular}{|c|c|}
\hline+ & - \\
\hline $\begin{array}{l}\text { discursivização da pessoa: } \\
\text { enunciativa da enunciação e } \\
\text { enunciva do enunciado }\end{array}$ & $\begin{array}{l}\text { discursivização da pessoa: } \\
\text { embreagem enunciva da enunciação } \\
\text { e/ou embreagem enunciva do } \\
\text { enunciado }\end{array}$ \\
\hline $\begin{array}{l}\text { discursivização do tempo e } \text { do espaço: } \\
\text { embreagem enunciativa do enunciado } \\
\text { (substituição do sistema enuncivo pelo } \\
\text { enunciativo) }\end{array}$ & $\begin{array}{l}\text { discursivização do tempo e } \text { do } \\
\text { espaço: debreagem enunciva do } \\
\text { enunciado }\end{array}$ \\
\hline $\begin{array}{l}\text { figurativização da rememoração coincidente } \\
\text { com o agora da narração }\end{array}$ & $\begin{array}{l}\text { ausência da figurativização da } \\
\text { rememoração coincidente com } 0 \\
\text { agora da narração }\end{array}$ \\
\hline $\begin{array}{l}\text { narrador afetado pela memória: narrador mais } \\
\text { paciente do que agente }\end{array}$ & $\begin{array}{l}\text { apresentação do passado como } \\
\text { objeto a ser analisado: narrador mais } \\
\text { agente que paciente }\end{array}$ \\
\hline
\end{tabular}

(c) ENUNCIADOR E NARRADOR

\begin{tabular}{|l|l|}
\hline \multicolumn{1}{|c|}{+} & \multicolumn{1}{|c|}{-} \\
\hline $\begin{array}{l}\text { grande recorrência de embreagens de } \\
\text { pessoa que confundem os níveis do } \\
\text { enunciador e do narrador }\end{array}$ & $\begin{array}{l}\text { pequena recorrência ou ausência de } \\
\text { embreagens de pessoa que confundem } \\
\text { os níveis do enunciador e do narrador }\end{array}$ \\
\hline
\end{tabular}

Algumas casas da segunda coluna do primeiro quadro poderiam ter ficado vazias. Acreditamos que, embora a presença de certos elementos possa fortalecer $\mathrm{o}$ efeito de identidade entre o enunciador e o protagonista, o contrário 
nem sempre é verdadeiro. Infância, por exemplo, apresenta-se como as memórias de infância do narrador, em identidade com o enunciador. Sua organização fragmentada, as repetições de certos acontecimentos confirmam nossas afirmações. O fato de nessa obra não serem relatados muitos eventos que extrapolem a vivência do menino (daí a ausência da genealogia, da citação de documentos ou da escritura de obras de autoria do enunciador) apenas reforça que o narrador conta o que sua memória permite, ou seja, somente o que recorda. Isso não enfraquece as três identidades, pelo contrário, elas são fortalecidas, mas por meio de outros procedimentos. É o que observamos também nos poemas estudados de Manuel Bandeira de forma ainda mais acentuada, pois em Bandeira parece revelar-se para o leitor o que o narrador está vendo ou sentindo, no exato momento em que toma a palavra.

\section{A PASSAGEM DO TEMPO}

Para formar o corpus desta tese, escolhemos entre os textos autobiográficos aqueles que traziam um percurso do ator do narrado ao longo do tempo. Sem dar importância à parte "quantitativa" desse tempo - Infância recobre apenas uns dez anos da vida de Graciliano, enquanto as Memórias de Pedro Nava começam muito antes de seu nascimento e chegam até sua mocidade -, selecionamos as obras em que é possível observar então certa duração. Trazemos, portanto, à luz tanto o tempo discursivo dado como cronotópico, como o tempo aspectualizado como duração. Starobinski, procurando definir a autobiografia em relação a outros gêneros autobiográficos, afirma que ela, assim como a biografia, introduz a noção de movimento e de duração:

A biografia não é um retrato, ou, se podemos tomá-la por um retrato, ela introduz a duração e o movimento. A narrativa deve cobrir um segmento temporal suficiente para que apareça o traçado de uma vida (1971, p. 257 ; tradução nossa) ${ }^{71}$.

\footnotetext{
71 "La biographie n'est pas un portrait; ou, si on peut la tenir pour un portrait, elle introduit la durée et le mouvement. Le récit doit couvrir une suite temporelle suffisante pour qu'apparaisse le tracé d'une vie".
} 
No nível tensivo, esse traçado se constrói pelas oscilações entre o acontecimento e o exercício. No nível discursivo, essa noção de duração pode ser recuperada sobretudo por meio da programação temporal, cuja principal característica é constituir-se como:

a conversão do eixo das pressuposições, que representa a ordem lógica do encadeamento dos programas narrativos, em eixo das consecuções, dando lugar assim à exposição temporal pseudocausal das ações narradas (GREIMAS; COURTÉS, 2008, p. 391).

Logo, aquilo que no nível narrativo consiste numa cadeia de pressuposições lógicas é convertido, no nível discursivo, num efeito de cronologia. Greimas e Courtés afirmam ainda que a programação temporal implica "uma medida do tempo em durações (introduzindo, assim, a aspectualização, que transforma os fazeres em processos)" (p. 391).

A programação temporal pode configurar-se no texto de formas diferentes. O primeiro capítulo de Baú de ossos trata da história dos antepassados do lado do pai do narrador e o segundo é dedicado à família de sua mãe. As peripécias narradas nesses dois capítulo se dão "ao mesmo tempo". Isso quer dizer que, embora no texto apareçam umas depois das outras, na ordem da "história" são simultâneas. A simultaneidade acaba quando as famílias se encontram por meio do casamento dos pais de Pedro Nava, e a história passa a ser uma só. Essa organização do texto pode ocorrer pois a programação textual, no quadro da textualização, efetua-se obedecendo às coerções e ainda tirando proveito das liberdades dadas pela natureza linear do texto verbal:

[...] pode-se distinguir uma programação textual propriamente dita (é assim que dois programas narrativos serão necessariamente dispostos em sucessão linear) da programação temporal (disposição dos diversos programas em ordem cronológica): esses dois tipos de programação deixam, entretanto, uma margem estratégica à organização dos discursos e dependem da competência discursiva do enunciador (GREIMAS; COURTÉS, 2008, p. 505). 
Nas obras estudadas, encontramos, na textualização, duas organizações temporais em conflito; chamamos uma de temporalidade dinâmica e a outra de temporalidade estática ${ }^{72}$. A temporalidade dinâmica, que cria o efeito de cronologia e de um tempo que passa, diz respeito à transformação de momentos acabados, pontuais e limitados. Ela funciona, nos discursos da memória, na seguinte direção:

$$
\text { passado } \leftarrow \text { presente }
$$

A temporalidade estática, dimensão própria do durativo temporal, possibilita a ruptura dessa linearidade, ao fazer perdurar os momentos. Ela traz para o presente algo daquilo que se tornou passado, produzindo uma inversão desse eixo temporal:

$$
\text { passado } \rightarrow \text { presente }
$$

Fiorin mostra que "[...] quando ocorre a sucessão narrativa que respeita o desenrolar progressivo dos acontecimentos, eles são em geral temporalizados pelos tempos verbais que indicam concomitância em relação ao momento de referência adotado" (1996, p. 243). Esses tempos podem ser o presente, o pretérito perfeito 2 , o pretérito imperfeito e o presente do futuro. Nas obras estudadas, entretanto, quase que somente o tempo que indica concomitância pontual a um marco temporal pretérito (o pretérito perfeito 2) é adotado com esse intuito, como no trecho em que Fernando, homem temido pelo menino em Infância, entorta os pregos de uma tábua para que as crianças não se machuquem: "Pois um dia a minha convicção se abalou profundamente. [...] Fernando levantou-se, apanhou-a, agarrou um martelo, pôs-se a entortar os bicos agudos, a rosnar. Desleixo. Se uma criança descalça pisasse naquilo? (IN, p. 227). O pretérito perfeito 2 apresenta múltiplos estados ou transformações como sendo sucessivos. Assim, cada nova ação é concomitante a um novo momento de referência que pode ser explicitado ou não.

\footnotetext{
${ }^{72}$ Como veremos, essas duas temporalidades conflitantes não se restringem à textualização, mas podem ser recuperadas também aquém dela.
} 
A preferência pelo pretérito perfeito 2 ocorre porque, em primeiro lugar, há, na maior parte das obras autobiográficas, predominância dos tempos enuncivos (maior em certas obras do que em outras), uma vez que o passado é o tempo forte. Com relação ao sistema enuncivo, notamos que o pretérito imperfeito é utilizado prioritariamente de modo a apresentar os fatos como simultâneos, formando um quadro contínuo, preso a um ponto de referência único. Quando o menino em Baú de ossos assiste, através do gradil do sobrado, ao movimento dos vendedores de rua, os verbos "ver" e "ouvir", no imperfeito, descrevem experiências que não são organizadas numa sequência temporal, criando a temporalidade estática: "Trepado no paredão de pedra e seguro ao gradil, não só eu via todas as cores do céu despencando, como ouvia os ruídos da rua, inseparáveis da impressão luminosa" (BO, p. 298).

Observamos nas obras autobiográficas um desenrolar progressivo dos eventos, determinado por grandes marcos temporais que organizam a ordem desses eventos em sequência, criando o efeito de um tempo que passou. Nos memoriais, servem de marcos temporais que ordenam a sucessão do tempo as viagens, os concursos, as etapas vencidas da carreira acadêmica, as publicações; tudo isso aparece ainda devidamente datado, o que confirma o lugar de cada fato na cronologia. Nas autobiografias literárias em prosa, encontramos viagens, nascimentos, casamentos, mortes, namoros, etc. Todos esses eventos, em ambos os gêneros, são geralmente apresentados pelo pretérito perfeito 2, que Ihes atribui dinamicidade. Os advérbios de tempo têm participação fundamental na criação da cronologia também, pois contribuem para ordenar a sucessão dos fatos. Os advérbios de espaço podem assumir a mesma função, eles sugerem a passagem do tempo por meio da mudança no espaço topológico.

Essa temporalidade dinâmica, que possui aspectualidade perfectiva (dinamicidade, pontualidade, acabamento), é constantemente permeada pela temporalidade estática, durativa e inacabada. As transformações estão, portanto, imersas em momentos em que a vida é descrita com o uso do pretérito imperfeito, oferecendo para o leitor a vida como ela "era": 
O Rio era então o mar e a cidade grande, o maravilhamento da luz, em contraste com uma São Paulo cinzenta e meio ameaçadora, mal percebida de passagem pelos quartos de hotel - sobretudo do City Hotel daquele tempo - ou no rebuliço assustador das ruas. Essas imagens se alternavam, em minha vida de menino, com as da roça, do mato e dos rios, do Campo Triste, das caçadas e pescarias, das fazendas de colonos que eu visitava muitas vezes com meu pai, no atendimento aos chamados dos doentes (ARRIGUCCI JR., 1990a, p. 1).

Não só o recorrente uso do pretérito imperfeito contribui para imobilizar a passagem do tempo, as embreagens também podem produzir tal efeito. As mais empregadas são as que substituem o pretérito perfeito 2 ou o pretérito imperfeito (enuncivos) pelo tempo presente (enunciativo), fazendo com que determinado evento possa vir a ocupar um lugar no presente da narração, o que o liberta da relação de sucessão imposta pela cronologia. Os momentos de rememoração estabelecem ligações entre instantes distantes temporalmente, que não constituem uma progressão linear contínua e dinâmica. São os encontros com o Tio Veloso que permitem ao narrador de $A$ menina do sobrado ligar lembranças separadas por anos:

Noutro capítulo contarei essa escapada, que o Tio Veloso, homem, bonachão, houvera perdoado com um gracejo. O que pede a pena agora é que eu agarre e bote no papel umas lembranças fujonas de 1916, enlaçadas a outras de 1921 e 1923, se não de 1924, ano em que vi pela última vez essa imponente figura, através de quem se poderia reconstituir toda uma época, do mesmo modo como o arqueólogo, por um torso de estátua ou mediante algum utensílio caseiro, consegue vislumbrar civilizações sepultadas sob milênios (ANJOS, 1994, p. 245).

Quando o narrador de Baú de ossos se recorda do momento em que, já adulto e diante da casa em que havia morado, relembra sua infância, há uma espécie de linha transversal que, cortando as várias camadas de tempo que se sobrepõem, une três instantes: o agora da narração, o momento em que o adulto está diante da casa e o tempo da lembrança, quando o narrador era ainda um garoto. Esses momentos não poderiam aparecer juntos caso fossem soberanas as coerções da "passagem do tempo", que substitui um momento pelo seguinte. Em Infância, a temporalidade linear e descontínua é recuperada com grande dificuldade pelo enunciatário. Conforme dissemos, o livro começa 
com a primeira lembrança do narrador, quando era um menino de três anos mais ou menos, e chega até os seus onze ou doze anos. Há, porém, fatos que parecem se repetir em seu interior. Além disso, embora as mudanças de cidade, a passagem pelas escolas e outras transformações na vida da criança e de sua família permitam estabelecer uma sequência, não temos como ter certeza se isso se aplica a todos os capítulos. Não sabemos se os eventos narrados no capítulo 15, por exemplo, ocorreram antes (na ordem da história relatada) que aqueles narrados no capítulo 16. Não há nada que indique isso. O efeito é de que a memória está por trás da textualização, fazendo conexões que extrapolam a cronologia.

Nos memoriais acadêmicos, reencontramos essas duas temporalidades, a dinâmica e a estática, mas a primeira parece imperar. Contamos por amostragem a ocorrência do pretérito perfeito 2 e do pretérito imperfeito em $30 \%$ das páginas das três obras literárias estudadas (Baú de ossos, Galo-dastrevas e Infância) e de três memoriais (MATIOLI, 2008; NEGRÃO, 2004 e PARDINI, 2007) e verificamos que, para elaborar o narrado, o imperfeito é mais usado do que o perfeito 2 nas obras de Pedro Nava e de Graciliano Ramos, enquanto nos memoriais predomina o pretérito perfeito 2. Logo, nos textos acadêmicos estudados, embora a tensão entre as duas temporalidades também se instale, prevalece o efeito de uma passagem "natural" do tempo, reforçando a ilusão de realidade buscada no gênero. Além disso, nos memoriais observamos um número menor de embreagens temporais, subvertendo a linearidade consecutiva. Também são menos frequentes os momentos em que o narrador ou o protagonista aparecem lembrando-se, de maneira explícita, de eventos anteriores a partir de algo que os afetou no presente, ligando assim pontos distantes. Esses momentos não são inexistentes nos memoriais, conforme mostramos, mas sua ocorrência é mais rara.

A suspensão da progressão dos fatos narrados fica a cargo, principalmente, dos momentos de reflexão, quando a relação entre as partes do enunciado é dada pela lógica própria ao tipo dissertativo de texto. Nessas interrupções, o tempo verbal predominante é o presente, de aspectualidade gnômica, cujo momento de referência é ilimitado, englobando inclusive o momento da enunciação (FIORIN, 1998, p. 151). Daí decorre o efeito de 
"verdade absoluta" que se atribui aos enunciados. Dahlet, após contar que o objeto de seus estudos de pós-graduação foi a literatura, analisada sob uma ótica cada vez mais linguística, justifica suas opções:

[...] não é à toa, por exemplo, que um poeta como Mallarmé tenha sido o primeiro a conceituar as "ciências da linguagem". A separação estanque entre ambas as disciplinas não favorece nenhuma delas. Um estudioso em ciências da linguagem (e, aliás, em ciências humanas) se sacrificaria muito se não aproveitasse dessa formidável fábrica de linguagens que constitui a literatura; assim como o estudioso em literatura sofreria, a meu ver, uma redução notável na apreensão do fenômeno literário sem a percepçao daquilo que suscita o escrito, condiciona-o, configura-o e atravessa-o sob a forma de não dito, ambivalência, ambiguidade, e, enfim, contradição (2004, p. 33).

Isso não significa que na literatura autobiográfica não existam momentos em que o relato seja suspenso para que o narrador possa dissertar sobre algum assunto, muito pelo contrário. A obra de Nava está repleta de reflexões a respeito da profissão de médico, do gênero, da própria memória, entre outros assuntos. O narrador, com uma linguagem bastante metafórica, procura compreender o "vaivém" das lembranças. A passagem serve para introduzir a descrição da imagem que emerge do prato de louça, oportunidade para viagens na imaginação, quando garoto:

Uns fatos voltam ao sol da lembrança com a rapidez dos dias para os mundos de pequena órbita. Vivem na memória. Perto do astro-rei, como Vênus e Marte. Há os distantes, como Saturno. Outros, cometas, passam roçando e queimando; depois somem em trajetórias mergulhadas nas distâncias espaciais do esquecimento. Tocam, com suas caudas, galáxias perdidas na mais prodigiosa altura das alturas; voltam, novamente, ameaçando arrasar tudo com o rabo de fogo. Como face de lua, aquele prato imaculado e duro. De ágate. Relutâncias diante do mingau transbordante. Comido aos poucos, iam aparecendo na borda as letras do alfabeto e os números de 0 a 9 (BO, p. 233).

Dos quatro poemas de Bandeira, "Infância" é o que mais sugere ao enunciatário a ideia de uma cronologia. São as indicações de idade, as mudanças espaciais (dadas pelos advérbios de espaço em sequência), os advérbios de tempo e alguns verbos no pretérito perfeito (1 e 2) que permitem 
recuperar a noção de sucessão, menos evidente do que nas obras em prosa, ainda que o poema tenha início com uma lembrança de quando o ator do narrado tinha em torno de 3 anos e termine com ele já aos dez. Em "Evocação do Recife", o efeito de cronologia pode ser depreendido, especialmente, a partir dos seguintes versos: "Um dia eu vi uma moça nuinha no banho/ Fiquei parado o coração batendo/ Ela se riu/ Foi o meu primeiro alumbramento". Esse trecho contribui para inserir a transformação no poema, dada por uma cisão. Antes dele, o menino parecia viver um momento de fusão total com o mundo. É essa primeira separação que o lança numa temporalidade orientada. A partir daí o pretérito perfeito começa a ser mais empregado e a infância vai chegando ao fim. Até mesmo o ponto final após "Meu avô morto.", que recupera o inexorável da morte, contribui para mostrar que o tempo passa. Já a temporalidade estática, que mostra cada momento vivido como inacabado, revela-se por meio do imperfeito, das frases nominais que retiram os eventos do tempo e da construção da memória que parece fazer-se à medida que as lembranças surgem no presente do sujeito recordador. Ela é dominante nos poemas analisados, com exceção de "Infância", que constitui um resumo acelerado da primeira década da vida do menino, enquanto oferece as imagens "paralisadas" do passado.

Em "Profundamente", o emprego repetido do pretérito perfeito cria uma sucessão: os verbos "adormeci", "despertei", "ouvi" compõem, desse modo, uma sequência. Entretanto, o poema, como um todo, vai do mais recente (a noite de ontem) ao mais antigo (quando eu tinha seis anos), revertendo o sentido da progressão temporal, algo que só a memória é capaz de fazer. Além disso, após a leitura da segunda parte, depreende-se um paralelismo entre as duas metades do poema e o advérbio "ontem" passa a poder ser lido como "quando eu tinha seis anos". Dois momentos distintos da vida do narrador são conectados e experimentados como coisa quase única, o que também constitui uma maneira de fazer a temporalidade estática penetrar na dinamicidade da passagem do tempo. Revela-se, com isso, que a memória pode unir momentos separados, como dois passados distintos, trazendo-os simultaneamente à presença do sujeito.

Em "Recife, ainda com Manuel Bandeira, a passagem do tempo (temporalidade dinâmica) é recuperada nos temas e figuras, não há como em 
"Infância" ou "Evocação do Recife" uma programação textual que produza o efeito de cronologia. O poema fala do desaparecimento de uma cidade, de sua transformação ao longo dos anos, mas também da permanência na memória do Recife primeiro. As figuras que remetem à vida numa cidade provinciana e euforizada ("Quando as crianças brincavam no meio da rua") opõe-se àquelas que dizem respeito à cidade moderna, como "arranha-céus". Se o tempo (a "vida") transformou o Recife da infância numa cidade estranha para o narrador, a memória foi capaz de reter a cidade querida. Embora dentro de cada estrofe haja alguma organização em sequência (Tomásia foi alforriada, depois trabalhou como cozinheira por toda a sua vida, depois morreu), não é a cronologia que dita a apresentação dos eventos lembrados nesse poema.

Um Recife ainda do tempo em que o meu avô materno

Alforriava espontaneamente

A moça preta Tomásia, sua escrava,

Que depois foi a nossa cozinheira

Até morrer,

Recife.

Ainda com relação aos poemas, não podemos deixar de mencionar a manutenção de algumas figuras nos quatro textos analisados. Os sintagmas que se repetem ao longo da obra de Bandeira recriam o movimento da memória, revelando a possibilidade de retorno do passado no presente, pelo menos enquanto linguagem poética. Elas resistem às transformações, à passagem do tempo, produzindo a temporalidade estática. Essa forma de recursividade caracteriza o fazer autobiográfico em Bandeira.

Para examinar o que ocorre num nível mais abstrato dos discursos da memória quando essas duas temporalidades entram em cena, podemos partir da categoria presença/ausência, cujas modulações fornecem a primeira modalização das relações entre o sujeito e o objeto tensivos, a modalização existencial. Reproduzimos o esquema já apresentado, que permite visualizar os diferentes modos da existência semiótica: 


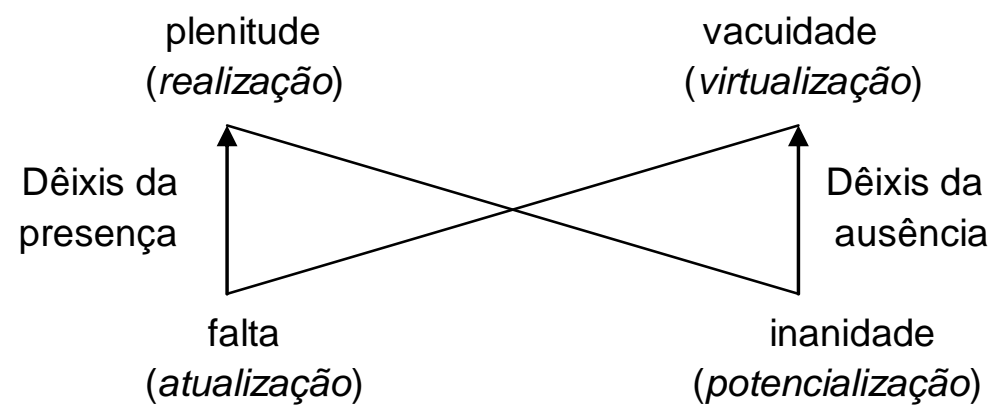

(FONTANILLE; ZILBERBERG, 2001, p 134)

Os discursos autobiográficos dão conta de dois percursos de maneira simultânea. Um deles leva da realização à virtualização, passando pela potencialização, e o outro vai da virtualização à realização, passando pela atualização. Vejamos o primeiro percurso. Ele corresponde a uma perda de densidade existencial de uma grandeza percebida pelo sujeito em seu aqui e agora. Essa direção é que leva à memorização, que podemos entender como uma das formas da potencialização:

Para a semiótica da presença, a memorização supõe, de um lado, o retorno dos dados realizados à condição de norma ou sistema em nosso universo cognitivo. De outro, supõe uma reabsorção da experiência sensível num quadro em que o tempo interno do sujeito, suspenso pelo choque do acontecimento, começa a se recompor até poder se reatualizar em discurso, não mais como agudeza sensorial de sua apreensão direta inicial, mas como inteligibilidade necessária para se tornar também um fato social. Por isso, dizemos que memorização em si corresponde à potencialização, combinando os aspectos átonos e tônicos da acepção do termo (TATIT, 2010, p. 154-155).

Tatit (2010) distingue a potencialização átona de uma potencialização tônica. A primeira diz respeito a uma atividade contínua de assimilação dos hábitos e estereótipos. Esses elementos possuem pequena densidade de presença quando realizados, atonia que mantêm conforme passam pelos diversos modos de presença. Ao serem "armazenados", compõem uma gramática que se realiza sob a forma de hábitos, além de propiciarem a estruturação de novas práticas significantes. 
Já a potencialização tônica diz respeito àquilo que "fora força, tonicidade, em realização" e que se torna "diferença, destaque, em potencialização" (p. 156). Os eventos marcantes podem, ao perder densidade de presença, permanecer na memória, como mostra o semioticista:

Só há uma forma de conservar a presença desse evento excepcional no campo de existência do sujeito: tirá-lo de foco e convertê-lo em potencialização. Ao perder densidade de presença, o acontecimento ganha uma zona pouco mais difusa no interior da extensidade, figurando ao lado de outros acontecimentos que diluem sua carga tensiva. Nesse estado - distensivo - o evento pode durar indefinidamente até que novas condições tornem urgente sua reconvocação (TATIT, 2010, p. 58).

Essas duas formas de memorização (potencialização átona $\mathrm{e}$ potencialização tônica), guardadas as devidas diferenças de quadro teórico, possuem alguns pontos em comum com as duas memórias de que trata Bergson (2006a, p. 91): a memória-hábito - "um hábito do corpo" adquirido por repetição - e a imagem-lembrança - lembrança de um momento único da vida de um sujeito. O filósofo as ilustra com uma lição aprendida de cor. A leitura repetida faz com que a lição possa ser decorada (memória-hábito). Quando reflete, porém, sobre esse processo, conclui: "Cada uma das leituras sucessivas volta-me então ao espírito com sua individualidade própria" (p. 86), está aí o que o autor considera a "memória verdadeira". Bosi recupera as propostas de Henri Bergson:

O passado conserva-se e, além de conservar-se, atua no presente, mas não de forma homogênea. De um lado, o corpo guarda esquemas de comportamento de que se vale muitas vezes automaticamente na sua ação sobre as coisas: trata-se da memória-hábito, a memória dos mecanismos motores. De outro lado, ocorrem as lembranças independentes de quaisquer hábitos: lembranças isoladas, singulares, que constituiriam autênticas ressurreições do passado (2001, p. 48).

Podemos dizer, então, que a memorização, qualquer que seja o seu grau, diz respeito mais ao esquecimento que à lembrança, entendidos esses termos como duas figuras recorrentes do discurso autobiográfico. $\mathrm{Na}$ potencialização átona, as experiências são incorporadas de forma desatenta, 
sem que o sujeito se detenha nelas. O motorista experiente não pode lembrarse de cada uma das operações que deve realizar para dirigir um carro. $\mathrm{Na}$ potencialização tônica, a perda de densidade de presença faz com que determinada grandeza possa ocupar um lugar extenso na memória e, assim, durar. Para que o acontecimento seja memorizado, o sujeito precisa, portanto, "esquecer" a força com que sobreveio.

Por isso, afirmamos que o percurso que vai da realização à virtualização corresponde a um esquecimento gradual, sendo a virtualização o momento em que a grandeza percebida está mais apagada para o sujeito, embora já incorporada a seu sistema de crenças e hábitos. É talvez o processo de memorização que leva Augé a afirmar que o esquecimento é a força da vida da memória, enquanto a lembrança é o seu produto:

É bem evidente que nossa memória ficaria rapidamente "saturada" se nós devêssemos conservar todas as imagens de nossa infância, em particular as da nossa primeira infância. Mas é o que resta que é interessante. E o que resta - lembranças ou vestígios, iremos voltar a isso -, o que resta é o produto de uma erosão pelo esquecimento. As lembranças são esculpidas pelo esquecimento como os contornos da costa pelo mar (AUGÉ, 1998, p. 29; tradução nossa) ${ }^{73}$.

Ao afirmar que nem tudo pode ser lembrado, o antropólogo nos obriga a olhar as relações entre esquecimento e memorização ainda sob outra perspectiva. Retemos em nossa memória a totalidade do passado? Essa é uma questão que os pesquisadores da memória vêm debatendo com bastante afinco. O trabalho do estudioso do discurso consiste, porém, em examinar como isso aparece nos textos analisados. Em Infância, observamos que são selecionados apenas os momentos mais marcantes da vida da criança: as rupturas. Logo, sobre a mistura, age a triagem, pois das numerosas experiências fica apenas o que afetou o menino. $\mathrm{O}$ esquecimento, como figura, recobre essa operação, própria da sintaxe extensiva (ZILBERBERG, 2004, p. 70). Ele é a concretização também de operações que regulam a sintaxe

\footnotetext{
73 "Il est bien évident que notre mémoire serait vite "saturée" si nous devions conserver toutes les images de notre infance, en particulier celles de notre toute première enfance. Mais c'est ce qui reste qui est intéressant. Et ce qui reste - souvenirs ou traces, nous allons y revenir -, ce qui reste est le produit d'une érosion par l'oubli. Les souvenirs sont façonnés par l'oubli comme les contours du rivage par la mer".
} 
intensiva: a atenuação e a minimização (ZILBERBERG, 2006a, p. 95). Para que as grandezas selecionadas possam ser retidas e perdurar, elas perdem intensidade. Também nas demais obras estudadas observamos que o passado se apresenta "aos pedaços". "Não é bem como eu disse antes, que anoitecia aqui, para acordar ali", afirma o narrador em Baú de ossos, "A memória é que suprimia intervalos [...]" (BO, p. 227). Entretanto, nas Memórias de Nava são selecionados e enfatizados, predominantemente, os momentos entre as rupturas, ou seja, a duração. A maneira como os tempos verbais são empregados confirma isso. Enquanto em Graciliano, o pretérito perfeito 2 apresenta fatos que obrigam o menino a mudar suas crenças e seu cotidiano, dados pelo pretérito imperfeito; em Nava, o pretérito perfeito 2, em muitos momentos, é empregado para narrar experiências que exemplificam aquilo que é descrito pelo imperfeito. Além disso, a memória é compreendida como algo que engloba as histórias ouvidas e lidas ao longo da vida, os objetos colecionados, as casas antigas e demais vestígios materiais. Tudo isso compõe o passado lembrado nos longos volumes das Memórias, que criam a ilusão de apresentar o passado em sua totalidade.

Assim, a temporalidade dinâmica concerne ao percurso orientado pelo esquecimento (passado $\leftarrow$ presente). A vida, elaborada como trajeto no discurso autobiográfico, constitui-se pela passagem das diversas grandezas realizadas para a potencialização e a virtualização. Esta é a direção que leva ao enfraquecimento das grandezas no campo de presença do sujeito. No entanto, a saída do modo realizado é o que permite a entrada na memória, sob a forma da memorização, posta "em cena" em diversas passagens:

[...] menino, moreno, tímido, meio sonso que se esgueirava entre os grandes e gostava de ficar pelos cantos olhando tudo, ouvindo tudo, guardando tudo, tudo. Armazenando na memória (seu futuro martírio) os fragmentos de um presente jamais apanhável, mas que ele sedimentava e ia socando quando eles caíam mortos e virados no passado de cada instante (BC, p. 228).

Na memória do doutor gravou-se a figura do primeiro tifento que ele viu depois de sair de Taquaraçu (GT, p. 136). 
Retomemos agora o segundo percurso. Ele leva da virtualização à realização, passando pela atualização, o que corresponde a um ganho de densidade existencial (passado $\rightarrow$ presente). É o que se passa durante a rememoração, embora não seja o vivido que retorna, mas uma imagem, um simulacro, que carrega valores que o sujeito recordador acredita serem semelhantes aos investidos nas experiências passadas. É importante enfatizar ainda que esses valores podem apresentar-se como repulsivos ou atrativos para aquele que se lembra. Não são todos os narradores que se mostram saudosos, é o que comprovam as obras Infância, de Graciliano Ramos, e Meus verdes anos, de José Lins do Rego.

Como dissemos, são os valores que podem voltar a ocupar o campo de presença do sujeito e não o passado em si. As operações sintáticas que constituem as saídas e entradas no campo de presença do sujeito ficam, de certa forma, registradas, pois alteram seu sistema de crenças e valores, assim como suas expectativas. Bergson afirma algo que vai no mesmo sentido, embora em um quadro teórico evidentemente diverso:

Pouco a pouco aparece como que uma nebulosidade que se condensasse; de virtual ela passa ao estado atual; e à medida que seus contornos se desenham e sua superfície se colore, ela tende a imitar a percepção. Mas continua presa ao passado por suas raízes profundas, e se, uma vez realizada, não se ressentisse de sua virtualidade original, se não fosse, ao mesmo tempo que um estado presente, algo que se destaca do presente, não a reconheceríamos jamais como uma lembrança (2006a, p. 156).

Nos gêneros autobiográficos, é a escritura que possibilita a passagem das lembranças ao modo realizado. A narrativa das memórias faz com que o que estava esquecido ou ainda com que aquilo cuja densidade de presença era baixa se realize no discurso. É esta direção, da ausência para a presença, que diz respeito à temporalidade estática e à rememoração. Não é demais dizer que a rememoração é responsável por fazer o passado tornar-se presente e o presente tornar-se futuro, entendido como espera, uma vez que o horizonte de expectativas do sujeito passa a contemplar a realização novamente do simulacro de um evento passado, a fim de que esse sujeito possa entrar outra vez em conjunção com valores desejados: 
O sujeito leva para o cotidiano a memória da experiência marcante e isso altera seu sistema de expectativas, do mesmo modo que as realizações linguísticas imprimem suas marcas no sistema das línguas naturais (TATIT, 2010, p. 57).

Assim como a memorização está sob a égide do esquecimento, na rememoração entra em jogo a lembrança, ou ainda, o lembrar, que podemos compreender como a figurativização do aumento da densidade de presença de determinada grandeza. Logo, nos textos autobiográficos analisados recuperase a tensão, em diversos níveis do percurso gerativo do sentido, entre as faculdades, dadas como figurativização discursiva, que parecem formar a memória: a lembrança e o esquecimento.

\section{A MEMÓRIA-ACONTECIMENTO E A MEMÓRIA DO ACONTECIDO}

A análise do corpus permite propor duas formas discursivas de construção da memória como categoria analítica dos discursos autobiográficos: a memória do acontecido e a memória-acontecimento. A memória do acontecido pode ser aproximada da figura do arquivo, por construir-se discursivamente como algo que parece estar pronto antes mesmo da redação do texto, como dado prévio. Ela fornece legibilidade ao passado, elaborado com o efeito de exaustividade de informações. Faz do passado lembrado, assim como do texto, objeto que deve ser analisado e explicado à distância, e cuja sustentação é fornecida pelo efeito de referência. Já a memóriaacontecimento aparece como construção que se realiza ao longo do texto. Ela é capturada em seu devir, em sua ação de fazer aparecer e desaparecer o passado lembrado. É dinâmica, instável. Não cria a ilusão de acabamento, mas a cada pedaço do passado agarra-se um máximo de engajamento afetivo do sujeito que produz o texto tanto quanto é por ele produzido. A memóriaacontecimento mostra o mínimo com o mais alto grau de força. É importante mencionar ainda que propomos essas duas "memórias" para analisar as relações entre enunciador e enunciatário. 


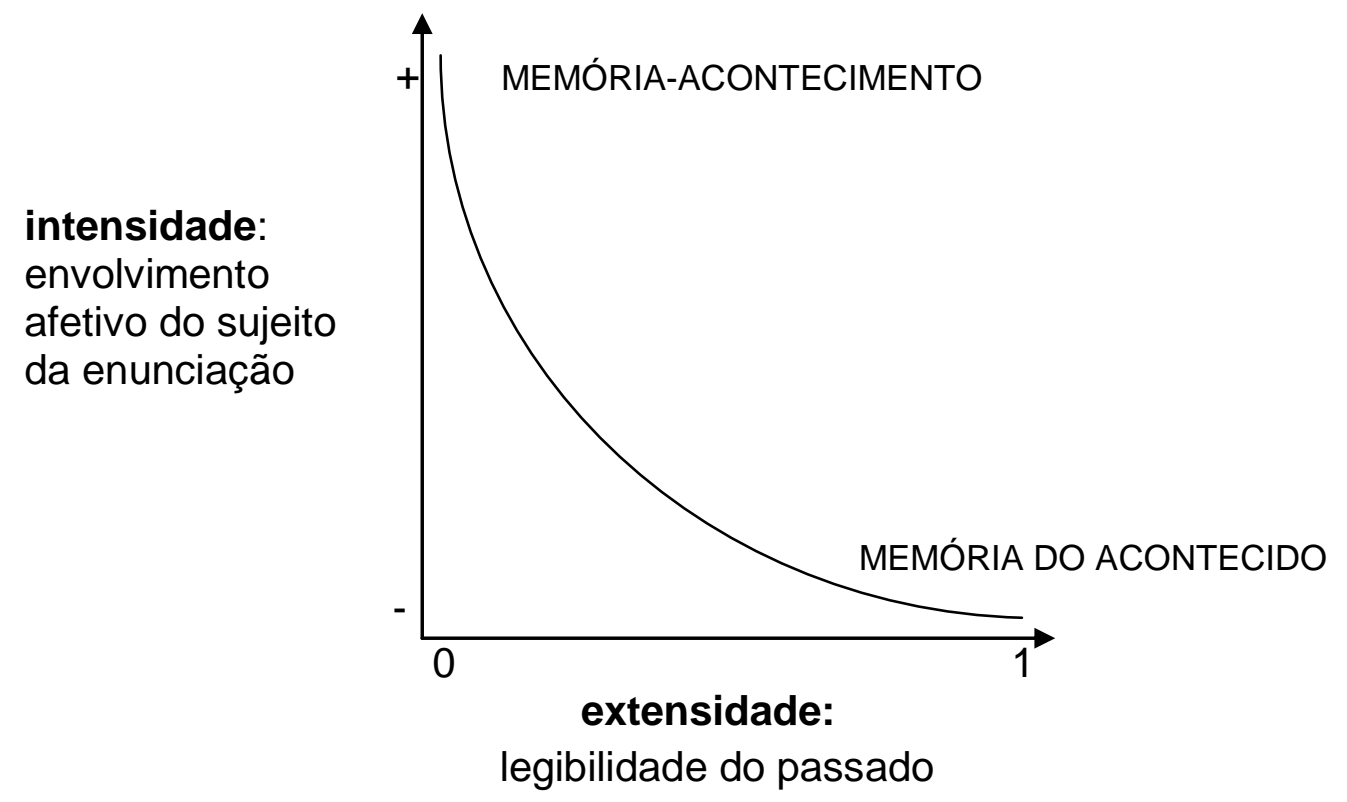

O acontecimento, numa acepção tensiva, pode aparecer em todos os níveis do discurso autobiográfico. No nível em que se dá a interação entre protagonista e mundo, surpresas como nascimentos e mortes podem ser acolhidas como aceleradas e impactantes. No nível da narração, as lembranças, em alguns momentos, parecem invadir de forma abrupta o campo de presença do narrador. Enfatizamos, porém, que a memória-acontecimento e a memória do acontecido concernem à enunciação e, assim, às diferentes formas de interação entre enunciador e enunciatário que encontramos nos gêneros autobiográficos. Retomemos comparativamente a análise dos poemas de Manuel Bandeira, em que predomina a memória-acontecimento, e dos memoriais acadêmicos, em que predomina a memória do acontecido.

Na primeira estrofe de "Profundamente", a festa emerge no poema, por meio de uma coleção de traços sensoriais, conforme mostramos: "estrondos", "rumor", "luzes", "vozes cantigas e risos", "fogueiras acesas" ("Quando ontem adormeci/ Na noite de São João/ Havia alegria e rumor/ Estrondos de bombas luzes de Bengala/ Vozes, cantigas e risos/ Ao pé das fogueiras acesas"). Esses traços só permitem ao leitor reconstruir para si uma "noite de São João" sensível. Não the é dada a possibilidade de precisar o ano ou o local em que a festa ocorreu. A única localização temporal é fornecida pelo "ontem", que estabelece, inicialmente, a anterioridade em relação ao agora da narração. Entretanto, mesmo essa localização de tempo torna-se imprecisa quando o leitor chega à segunda estrofe, o que permite entender tal advérbio como uma 
embreagem e "ontem" passa a ser compreendido como "quando eu tinha seis anos". Tudo se passa como naquelas imagens da gestalt, nas quais vemos mais de um desenho ao mesmo tempo, desestabilizando nossa crença na realidade.

Essa forma fragmentária de apresentar o passado também reencontramos em "Evocação do Recife", "Infância" e "Recife". Especialmente nos dois primeiros, é construída uma sequência de imagens que parecem ser narradas à medida que vêm à memória do sujeito recordador. As marcas de oralidade, o tamanho variado dos versos correspondendo a uma imagem singular do passado, a falta aparente de uma ordem prévia são alguns dos recursos que contribuem para criar a impressão de que as lembranças são narradas conforme emergem. Além disso, o emprego reduzido de conectivos ligando a série de recordações, a abundância de frases sem verbos ou com verbos empregados em suas formas nominais - como em "Corridas em círculos riscados na areia...", ou "Eu, junto do tanque, de linha amarrada no incisivo de leite, sem coragem de puxar" -, a falta de uma ordem explicitada que traga alguma previsibilidade ao discurso fazem com que o sujeito da enunciação (enunciador e enunciatário) também experimente a passagem abrupta de uma lembrança a outra. A leitura é acelerada e impactante.

Outro fator que corrobora a desestabilização da leitura dos poemas diz respeito à sobreposição de pontos de vista, o do narrador e o do menino, observada em diversas passagens. Em "Evocação do Recife", o dêitico "lá" faz com que se sobreponha o narratário a um interlocutário, assim como o narrador ao interlocutor, criando certa ambiguidade actancial: "Do lado de lá era o cais da Rua da Aurora..." ou "Lá longe o sertãozinho de Caxangá".

Soma-se a isso a incompletude com que as cenas são mostradas enfatizam-se os traços sensoriais e afetivos do passado - e a dificuldade que o enunciatário encontra de localizar-se no tempo e no espaço de forma mais precisa. A memória é apresentada em ação, velando e desvelando o passado para o leitor. O próprio poema aparece em Bandeira como parte de uma memória que se forma ao longo de sua obra. A reiteração das figuras não enfraquece a forte impressão experimentada pelo enunciatário; pelo contrário, ela intensifica a apropriação das lembranças narradas, tanto por parte do enunciador quanto por parte do enunciatário. 
O impacto é amenizado apenas parcialmente pela ordem cronológica, depreendida ao final da leitura de "Evocação do Recife" e "Infância". As marcas para recuperá-la são escassas, principalmente no primeiro. Além disso, a localização espacial e temporal - e isso vale para os quatro poemas - é recriada sobretudo a partir da ligação com 0 ator biografado. Não são apresentados lugares históricos, turísticos ou ligados ao poder, mas aquilo que o narrador (enunciador) incorpora como seu. Daí a sequência de negativas que "desbasta" o Recife de seus predicados usuais ("Veneza americana", "Mauritsstad dos armadores das Índias Ocidentais", "dos Mascates"). Essas formas reificadas são vistas no poema como algo que, tendo origem num conhecimento quase institucional da cidade, seja ele científico, seja ele literário, dessemantizou-se pelo "desgaste" discursivo, ao contrário do que ocorre com as formas fixas que remetem a um conhecimento popular da cidade, como os bordões das brincadeiras que encontramos em "Evocação do Recife". Enquanto aquelas gozam de uma assunção fraca por parte do enunciador, estas, tratadas como regeneradoras, são assumidas com intensidade ${ }^{74}$.

Os poemas de caráter autobiográfico parecem propiciar, portanto, a preponderância da memória-acontecimento, que funde tempos, espaços, pessoas, num processo de compactação. Não é apenas o passado que vem à tona, mas a presença de um sujeito no passado. As sensações e emoções são (re)vividas na linguagem pelo enunciador e pelo enunciatário. É este o domínio da experiência sensível. A memória-acontecimento é, então, potência, que pode desestabilizar a diferenciação entre os níveis do protagonista, do narrador e do enunciador. Da mesma forma que a reminiscência cria uma "ilha" no cotidiano daquele que recorda, a memória-acontecimento se instaura como fratura para o sujeito da enunciação, destacando-se do que é rotina.

Já nos memoriais deparamos com outra maneira de organizar o discurso, mais de acordo com a memória do acontecido. A vida lembrada é elaborada de forma a revelar uma coerência que confirma tanto a competência do enunciador, capaz de bem organizá-la enquanto texto, como a do ator do narrado, que é mostrado como alguém que conseguiu viver de forma

${ }^{74}$ É preciso dizer ainda que a incorporação de variantes linguísticas tidas no Brasil como de menor prestígio e assumidas pelo Modernismo como um falar "mais brasileiro" constituía, na época de publicação dos poemas, algo bastante inovador e que também causava surpresa e estranhamento ao leitor. 
harmoniosa, desviando-se pouco de seu programa de busca, iniciado muitas vezes já na infância.

Até aqui estamos falando da enunciação. Quanto ao enunciado, é preciso dizer que nem mesmo nos memoriais a vida se apresenta como algo absolutamente planejado. O imprevisível também tem seu lugar no gênero institucional. Os acontecimentos que abalam o ator do narrado revelam, por um lado, seu heroísmo, pois ele vence os "obstáculos" ou "desafios"; por outro, criam o efeito de realidade próprio ao gênero: a vida é simulada como algo que não se deixa antever por completo.

Grande parte daquilo que ocorre como acontecimento para o ator do narrado, sob o olhar atento e distanciado do narrador, pode receber a exposição implicativa, aproximando-se do que Zilberberg (2007) propõe como exercício. O narrador revela, assim, o pesquisador competente que parece ser. Recuperamos mais uma vez as palavras de Negrão, que, na narração, reconhece aquilo que foi um "grande fracasso" para o ator do enunciado como uma das "causalidades" que tornaram novas conquistas possíveis.

Não conseguir minha primeira opção foi um grande fracasso para mim naquele momento. Hoje, no entanto, vejo meu ingresso na segunda opção como uma das causalidades que mudaram o meu percurso (NEGRÃO, 2004, p. 8: grifos nossos).

Nesses casos, o acontecimento restringe-se ao narrado (nível 3 do esquema), que diz respeito às relações entre o protagonista e o "mundo". A memória no gênero institucional é guiada, geralmente, por uma intencionalidade, pelo dever de tudo explicar, tornando o passado inteligível para o leitor. Além da dominância da lógica implicativa, contribui para aumentar a nitidez do passado, a abundância de topônimos, antropônimos e cronônimos. Tudo é datado. Os atores, sempre apresentados com nome e sobrenome, são mostrados a partir de seu papel temático (professores, alunos, etc.). Os locais das comunicações, dos congressos, das aulas ministradas e frequentadas ancoram-se num endereço que pode ser facilmente reconhecido pelo leitor.

Em meados de 1993, o SENAC me convidou para fazer uma palestra em Salvador, no lançamento do livro África: moda, cultura e tradição, que reunia textos de Fábio Ávila e Fábio Leite (e algumas citações de 
minha tese) (219), sobre fotos do vestuário africano feitas por Maureen Bisilliat em Abijan (PETTER, 2008, p. 24).

As datas e eventos partilhados pela comunidade acadêmica ou mesmo por um grupo maior ordenam as atividades cronologicamente, produzindo o efeito de uma passagem "natural" do tempo, sem fazer fracassarem as expectativas do enunciatário: a sequência organizada gera o conforto de saber o que esperar do próximo item, saber confirmado à medida que o enunciatário avança na leitura do memorial.

Se nos poemas o narrador e o protagonista podem, em diversos momentos, experimentar as mesmas sensações, o que os identifica ainda mais, nos memoriais acadêmicos, podemos, quase sempre, separá-los. Nos memoriais, são poucas as embreagens que, substituindo os tempos enuncivos pelos enunciativos, presentificam o passado, aproximando-o da enunciação. Com relação aos tempos enuncivos, observamos ainda a dominância do pretérito perfeito 2, que mostra os fatos como acabados, sobre o imperfeito, que, ao contrário, faz ver os eventos em sua duração. Isso apenas corrobora a dissociação entre 0 narrador e 0 ator do narrado. $O$ modo de construir os espaços também produz semelhante efeito, já que é o espaço enuncivo que predomina nos memoriais. O passado é relatado como experiência espaçotemporal sem continuidade com o aqui e o agora da narração. Nas reflexões metalinguísticas, quando o narrador fala sobre o gênero ou sobre a escritura do texto, tomando-os como linguagem a ser examinada, acentua-se ainda mais a distância em relação ao ator do narrado: "O fazer um memorial pode ser comparado à montagem de um álbum de fotografias" (NEGRÃO, 2004, p. 4).

A textualização também confirma nossas afirmações. A presença inconstante de um léxico que expressa emoção ou de interjeições, assim como a pontuação e a sintaxe empregadas raramente com efeito poético instauram um narrador cujo simulacro é o daquele que não se deixa envolver pelas memórias. O sujeito do vivido, que experimentou as sensações e emoções, está bem encerrado num tempo pretérito.

Há, contudo, alguns momentos em que o narrador dos memoriais se revela surpreendido por uma lembrança, perdendo o controle da rememoração: 
A primeira lembrança que eu posso registrar com relação ao meu interesse pela área biológica data de 1961, aos quatro anos de idade, ao acompanhar o sofrimento de minha avó Kasemira (materna) que estava com câncer terminal. Prometi solenemente a ela que torna-me-ia um médico para poder curá-la. Desde então ocorre-me uma série de outras memórias relacionadas a esse interesse. Algumas mais marcantes são os experimentos realizados com tatus-bolinha e formigas, sendo alguns deles de natureza sádica como ocorre naturalmente em várias crianças, mas outros de natureza lúdicocientíficas, tais como a construção de labirintos (com jogos infantis de construção que meu pai, que sempre trabalhou com construção civil, gostava de me presentear) para os pobres bichinhos que teimavam em usar as paredes para seu desvencilhamento (MATIOLI, 2001, p. 2).

Nesse caso, o acontecimento irrompe apenas no nível da narração (nível 2), em que se dá a interação entre o narrador e a memória narrada. A organização discursiva do memorial não chega, no entanto, a fazer da obra um acontecimento para o enunciador ou para o enunciatário (nível 1). As lembranças vindas do passado são bem organizadas no relato para o leitor. Não há lacunas a serem completadas. O narrador explica, com certo número de detalhes, as experiências com os insetos, utilizando-se de períodos compostos por subordinação, sem fragmentar a sintaxe ou a semântica do texto. O mundo produzido nos memoriais aparece, geralmente, como se fosse preexistente ao ato de lembrar e ainda de narrar. O narrador teria o papel de contar o que já é dado e confirmado pela documentação anexa ao texto, conforme mostram as indicações: “doc1, “doc2”, “doc3”... Mesmo quando o narrador informa que foi sendo modificado pela experiência da escritura autobiográfica, isso, na maior parte dos casos, não é confirmado por seu "dizer".

É nesse sentido que podemos falar num favorecimento à memória do acontecido nos memoriais acadêmicos examinados: o enunciador "comprova" suas competências para a pesquisa e a docência ao "auscultar" seu passado minuciosamente e de longe. Revelam-se nos memoriais as regularidades escondidas sob o caos aparente. O enunciatário é assim manipulado por meio de estratégias mais da ordem do inteligível. A memória do acontecido reforça os contornos que separam e distinguem os níveis internos do enunciado autobiográfico, promovendo o desdobramento (em oposição à compactação 
dada na memória-acontecimento). Para o sujeito da enunciação, constrói-se como continuidade, não causa desconforto ou estranhamento.

Isso não significa que a memória-acontecimento não possa fazer-se presente nos memoriais. Arrigucci (1990a), com grande concisão, reconstrói no texto a relação que tinha quando menino com o campo e duas grandes cidades, São Paulo e o Rio de Janeiro. O encontro com elas perturba a criança, mas não apenas ela, pois a maneira como a passagem é construída impacta o sujeito da enunciação. Conforme mostramos, a metonímia - "Rio era então o mar" -, que faz caber todas as impressões da criança numa oração curta, causa forte impressão sobre o enunciatário. Podemos afirmar então que a memória-acontecimento se realiza localmente nos memoriais, dominados pela memória do acontecido ${ }^{75}$.

A mesma observação pode ser aplicada aos poemas de caráter autobiográfico. A memória-acontecimento é o elemento global, mas nem por isso elimina por completo a memória do acontecido, que permanece de maneira local ${ }^{76}$. O poema "Infância" procura equilibrar o desconforto produzido sobre o enunciatário pela memória-acontecimento, dando-lhe alguns momentos para a recuperação da inteligibilidade dos versos, embora domine uma poética do impacto e da aceleração. O primeiro verso traz, num sintagma nominal, uma cena sem qualquer ancoragem de tempo ou de espaço, e ainda sem identificação onomástica particularizando os atores. Quem são os ciclistas? 0 que fazem ali? Nos versos seguintes, porém, o enunciatário pode compreender melhor o que se passa: a "corrida de ciclistas" faz parte das memórias do narrador. A idade de "três anos", no verso finalizado por um ponto de interrogação, ainda que ancore o evento de maneira vaga, fornece um pouco mais de estabilidade àquele que percorre o poema. $\mathrm{O}$ mesmo se dá por meio do uso do nome da cidade: "Petrópolis".

\footnotetext{
${ }^{75}$ Essas considerações valem apenas para o modelo 2 de memorial acadêmico. Nos textos do modelo 1, praticamente não encontramos essa maneira de organizar a linguagem e o discurso (ver capítulo 3).

76 Seria necessário comprovar essas afirmações a respeito dos poemas de caráter autobiográfico por meio do exame da obra de outros autores, pois apenas analisamos de forma sistemática os quatro textos selecionados de Manuel Bandeira.
} 
Corrida de ciclistas.

Só me recordo de um bambual debruçado no rio.

Três anos?

Foi em Petrópolis.

Os diversos gêneros que compõem o corpus desta pesquisa podem, então, ser organizados num gradiente que tem num dos extremos os memoriais acadêmicos e, no outro, os poemas de caráter autobiográfico. As autobiografias literárias em prosa e, assim, os romances autobiográficos encontram-se entre as duas pontas, ora tendendo para uma, ora para a outra extremidade, conforme mostraremos a seguir ${ }^{77}$.

\section{intensidade: \\ envolvimento \\ afetivo do sujeito \\ da enunciação}

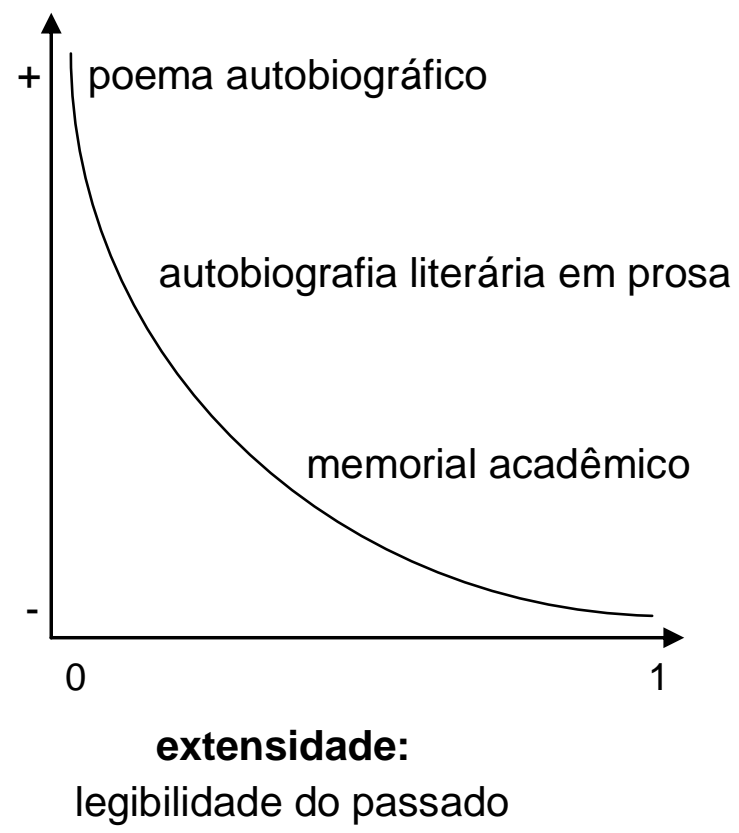

A autobiografia literária em prosa combina de forma mais equilibrada as duas configurações discursivas da memória, mas em cada autor analisado isso aparece de maneira singular. Vejamos como a memória-acontecimento é construída na obra Infância, que começa com a primeira lembrança do narrador:

\footnotetext{
${ }^{77}$ É preciso dizer ainda que o esquema apresentado organiza comparativamente os gêneros com os quais trabalhamos, observados sempre em relação uns aos outros e não de forma absoluta ou isoladamente. A entrada de outros gêneros, como o currículo, que apresenta as atividades em forma de lista e não favorece o surgimento de um estilo autoral, reorganizaria em parte o esquema, pois tal gênero é ainda menos propício à aparição da memóriaacontecimento que o memorial acadêmico.
} 
A primeira coisa que guardei na memória foi um vaso de louça vidrada, cheio de pitombas, escondido atrás de uma porta. Ignoro onde o vi, quando o vi, e se uma parte do caso remoto não desaguasse noutro posterior, julgá-lo-ia sonho. Talvez nem me recorde bem do vaso: é possível que a imagem, brilhante e esguia, permaneça por eu ter comunicado a pessoas que a confirmaram. Assim, não conservo a lembrança de uma alfaia esquisita, mas a reprodução dela, corroborada por indivíduos que lhe fixaram o conteúdo e a forma. De qualquer modo a aparição deve ter sido real. Inculcaram-me nesse tempo a noção de pitombas - e as pitombas me serviram para designar todos os objetos esféricos. Depois me explicaram que a generalização era um erro (IN, p. 9).

Essa é uma recordação rodeada de incertezas. O narrador não sabe datá-la ou localizá-la com precisão, apenas consegue inseri-la, não na cronologia de sua vida, mas na de suas memórias: trata-se da primeira coisa memorizada. Não pode assegurar a "realidade" do evento que originou a lembrança, modaliza-o como possível (poder-ser) e ainda como verossímil (parecer-ser). Em seguida, ele admite que a imagem registrada, na verdade, é fruto de conversas posteriores.

Já temos aí um prenúncio do que será o livro, cuja organização parece imitar o ir e vir da memória. Os capítulos são constituídos a partir de relações associativas, um evento narrado atrai o outro. "Verão" finda com uma reflexão acerca das causas que faziam o pai ser tão violento e o capítulo seguinte, "Um cinturão", mostra-o justamente exercendo toda a sua agressividade. "Padre João Inácio", "O fim do mundo" e "Inferno" tratam de temas ligados de algum modo à religião. Talvez isso explique o fato de serem apresentados numa sequência. Alguns eventos parecem ser narrados mais de uma vez. No capítulo "Meu avô", o narrador conta a respeito de uma viagem feita à fazenda de seu avô, durante a qual nasceu um irmão: "Afinal minha mãe largou choco. Estava pálida, sem ventre, a saia arrastando, fraca e bamba. E amamentava uma criança chorona“ (IN, p. 135). Alguns capítulos depois ("Minha irmã natural"), ele fala do sumiço de um membro da família, no caso, Mocinha, e do aparecimento de outro. Ambos os eventos se passaram ao longo de uma visita à fazenda de seu avô: "O ganho foi representado por um menino chorão, que morreu cedo" (IN, p. 163). Tudo indica tratar-se da mesma viagem, embora não haja qualquer comentário a esse respeito. 
Além disso, nessa obra, o narrador fixa-se principalmente nos momentos vividos pela criança e na percepção que tinha do mundo à sua volta, sem ultrapassar demais os limites de suas experiências. Mesmo sobre os antepassados temos poucas notícias, o narrador fala apenas de bisavós, avós e pais e, ainda assim, sem se alongar muito. Todos esses elementos fortalecem a impressão sobre o leitor de que a matéria dessa obra não é o passado, mas a memória do passado. Isso não significa que o livro não fornece uma visão da sociedade que cercava o menino, apenas não são retratados muitos fatos dos quais ele não participa diretamente ou sobre os quais não teve notícia ainda garoto. A história de seu Afro, que morava com a esposa e um compadre e que só pôde ser compreendida mais tarde, é relembrada mostrando que o julgamento conservador da cidade ficou, de certa forma, impregnado no menino e, depois, no homem, o narrador. Entretanto, é importante notar que, embora o narrador afirme não conseguir livrar-se da visão adquirida quando menino, ele a comenta de forma crítica, criando uma distância entre $o$ adulto e a criança:

Contudo esse julgamento absurdo acompanhou-me. Fixou-se, ganhou raízes. Indigno-me, quero extirpá-lo, reabilitar seu Afro e d. Maroca. Duas pessoas normais. Penso assim. E desprezo-as, sinto-as decaídas. Impossível deixar de senti-las decaídas. Repito mentalmente os desconchavos de padre João Inácio (IN, p. 58).

As determinações da memória impedem uma apresentação absolutamente linear do passado, mas ainda assim é possível notar que a história começa quando a criança tem entre dois ou três anos de idade e termina com ela na pré-adolescência, com aproximadamente onze anos. A cronologia é estabelecida, mesmo que de maneira frágil. Há poucas datas e outros marcos temporais, como acontecimentos históricos, ou a identificação da idade das pessoas. Quando tais recursos são utilizados, sua função principal parece não ser a de ancoragem. $O$ narrador afirma que o pai era muito cético e sem imaginação e que, por isso, durante muito tempo não acreditou em aeroplanos: "Em 1934 considerava-os duvidosos" (GR, p. 55). A data é fornecida mais para intensificar a incredulidade do pai do que para inseri-la numa ordem. Afinal, não sabemos a data de diversos fatos narrados 
antes e depois disso. A passagem do tempo é marcada, sobretudo, pelas mudanças de estação e por alterações climáticas, e também pelos deslocamentos espaciais, mais especificamente, as viagens da família

Ao contrário do que vimos em Baú de ossos ou Galo-das-trevas, para delimitar o momento em que certos eventos se deram, o narrador de Infância usa "um dia", "naquele tempo", entre outros advérbios do mesmo tipo, criando um passado indeterminado semanticamente, mas organizado nuclearmente sob o marco pretérito.

Datam desse tempo as minhas mais antigas recordações do ambiente onde me desenvolvi como um pequeno animal. Até então algumas pessoas, ou fragmentos de pessoas, tinham-se manifestado, mas para bem dizer viviam fora do espaço. Começaram pouco a pouco a localizar-se, o que me transtornou. Apareceram lugares imprecisos, e entre eles não havia continuidade. Pontos nebulosos, ilhas esboçandose no universo vazio (IN, p. 12).

Um dia faltou água em casa (IN, p. 28).

Essa indeterminação semântica do passado, isto é, figurativa, própria de um modo de lembrar e esquecer, também ressoa na construção atorial e espacial. Os sobrenomes, bastante raros, são usados normalmente quando a pessoa era chamada e conhecida por todos por nome e sobrenome. Sua primeira função não parece ser criar a ilusão do real. Os atores são caracterizados principalmente por suas ações e pelas relações que possuem com a criança, com seus familiares e amigos. A casa da família em Buíque é localizada não apenas pela rua onde fica, mas pela vizinhança, embora não seja fornecida muita informação sobre os vizinhos: "A nossa casa era na rua de Palha, junto à de d. Clara, pessoa grave que tinha diversos filhos, um gato, marido invisível" (IN, p. 59).

Todos os recursos apresentados - como a organização que "imita" os movimentos da memória, a indeterminação temporal e espacial, entre outros apontam para uma memória-acontecimento. Resta tratar, portanto, da memória do acontecido, que também compõe Infância. Em algumas passagens da obra, é elaborada uma descrição minuciosa dos espaços, como ocorre em "A vila", capítulo dedicado a uma apresentação de Buíque, no qual o narrador constrói a 
cidade como "um corpo aleijado" (IN, p. 51). Nesse capítulo, ele localiza, sempre em relação ao "corpo", as ruas e locais importantes de Buíque, como a escola, as casas de conhecidos ou pessoas ilustres, o largo, entre outros: a casa de seu Galvão ficava na virilha, a rua da Pedra e a rua da Palha serviam de pernas (uma dobrada, a outra esticada), um dos becos formava o cotovelo. Nesse capítulo, temos também algumas informações mais precisas a respeito do funcionamento e da organização social da vila. São apresentados os grupos familiares mais poderosos e os lugares que frequentavam, o papel desempenhado pelo pai nessa microssociedade, entre outros.

Além disso, embora o livro Infância seja construído como simulacro da memória, o narrador - desta vez, não ao modo do acadêmico, como nos memoriais, mas do literato - estabelece, em muitas passagens, certa distância para narrar o passado. Quando descreve os pensamentos e sensações da criança após ver o ossuário no cemitério, afirma: "Estas letras me pareceriam naquele tempo confusas e pedantes. Mas o artifício de composição não exclui a substância do fato" (p. 191). Em alguns momentos, ele mescla a rememoração ao exercício metalinguístico, como se procurasse controlar as irrupções da memória, nada desejadas, conforme observamos no primeiro capítulo da tese, já que o passado carrega valores disfóricos. Assim, o narrador examina em muitas passagens a maneira como narra o passado, descolandose da matéria narrada, ao criar esse outro nível de linguagem. É preciso dizer que, ao fazer isso, ele também observa a forma como sua própria memória funciona:

Desse antigo verão que alterou a vida restam ligeiros traços apenas. E nem deles posso afirmar que efetivamente me recorde. $O$ hábito me leva a criar um ambiente, imaginar fatos a que atribuo realidade. Sem dúvida as árvores se despojaram e enegreceram, o açude estancou, as porteiras dos currais se abriram, inúteis. É sempre assim. Contudo ignoro se as plantas murchas e negras foram vistas nessa época ou em secas posteriores, e guardo na memória um açude cheio, coberto de aves brancas e de flores. A respeito de currais há uma estranha omissão. Estavam na vizinhança, provavelmente, mas isto é conjectura. Talvez até o mínimo necessário para caracterizar a fazenda meio destruída não tenha sido observado depois. Certas coisas existem por derivação e associação; repetem-se, impõem-se - e, em letra de fôrma, tomam consistência, ganham raízes. Dificilmente pintaríamos um verão nordestino em que os ramos não estivessem pretos e as cacimbas 
vazias. Reunimos elementos considerados indispensáveis, jogamos com eles, e se desprezamos alguns, o quadro parece incompleto (IN, p. 27-28).

Nessa obra, os limites que separam os níveis do discurso autobiográfico não são sempre rompidos. As embreagens de tempo, que presentificam o passado, realizam-se geralmente de forma pontual pelo emprego do advérbio "agora" no lugar de um advérbio enuncivo:

Em noites comuns, para escapar aos habitantes da treva, eu envolvia a cabeça. Isto me resguardava: nenhum fantasma viria perseguir-me debaixo do lençol. Agora não conseguia preservar-me. O tição apagado avizinhava-se com a salmoura que vertia de gretas profundas (IN, p. 98).

Se o narrador e o ator do narrado podem ser identificados por meio da sintaxe discursiva - ambos são designados pelo pronome pessoal eu -, outros elementos mantêm a separação entre eles, como o pequeno emprego das neutralizações temporais. As ironias do narrador também contribuem para distinguir a sua visão sobre o passado da que possuía dos mesmos fatos quando menino. A criança estava mais de acordo com a visão de mundo da família ou ao menos tentava inserir-se nela. No capítulo "Adelaide", a surpresa do menino com relação ao que chama "inversão de papéis", ou seja, com o fato de uma professora negra maltratar sua prima branca, com "alma de proprietária", revela a imersão da criança numa sociedade de valores escravocratas, mesmo após a abolição. O narrador mostra, ironicamente, que, quando era garoto, via como naturais essas relações de poder, sem compreender por que as professoras negras se revoltavam contra sua prima que, a seu ver, não Ihes havia causado nenhum mal. O leitor, porém, compreende que a posição do adulto é outra:

Não me ocorria que alguém manejara a enxada, suara no cultivo do algodão e da cana: as plantas nasciam espontaneamente. [...] Lugar de negro era na cozinha. Por que haviam saído de lá, vindo para a sala, puxar as orelhas de Adelaide? Não me conformava. Que mal Ihes tinha feito Adelaide? (IN, p. 185). 
Outros elementos também possibilitam a distinção entre o menino e 0 adulto. No trecho apresentado a seguir, as reflexões do narrador realizam-se por meio do uso do presente ("penso", "recordo-me"), o que as distingue das sensações vividas pela criança, dadas pelo pretérito imperfeito ("achava-me”, “cerravam-se"):

Achava-me num deserto. A casa escura, triste; as pessoas tristes. Penso com horror nesse ermo, recordo-me de cemitérios e de ruínas mal-assombradas. Cerravam-se as portas e as janelas, do teto negro pendiam teias de aranha (IN, p. 36).

São selecionados nessa obra momentos arrebatadores para o ator do narrado, mas que o narrador deseja apresentar "de longe". Cada capítulo conta, geralmente, uma grande transformação vivida pela criança de forma violenta, sem que ela pudesse estar preparada. Ela se vê obrigada, então, a refazer o seu pequeno mundo a cada instante, não consegue perceber uma lei que lhe permita estabelecer algumas previsões e, assim, agir. Chama-nos a atenção a grande recorrência de experiências de aspecto incoativo: "A primeira coisa que guardei na memória" (IN, p. 9), "Pela primeira vez falaram-me no diabo" (IN, p. 28), "As minhas primeiras relações com a justiça foram dolorosas e deixaram-me funda impressão." (IN, p. 34), "Eu nunca tinha visto um cadáver" (IN, p. 95), "pela primeira vez ri de mim mesmo" (IN, p. 204). As mudanças aspectuais, marcadas pelas primeiras vezes, são responsáveis por dar início a uma nova duração.

Assim, para aquele menino cada acontecimento parece isolado, sem repetição. Já o narrador adulto dá pistas de que o que era antes entendido como gratuidade repete-se sempre dentro e fora da família. O passado é para ele durativo descontínuo. Parecia que mudava o tempo todo, mas na verdade estava sempre igual. A sociedade permanecia patriarcal, violenta, escravocrata.

A narrativa das memórias dota de algum sentido esse universo e ainda constitui um modo de opor-se a ele. O narrador, por meio do relato, adquire o saber-fazer e também o poder-fazer, como ao procurar explicar as atitudes do pai, a partir de seu pertencimento às camadas médias da sociedade: 
Hoje acho naturais as violências que o cegavam. Se ele estivesse embaixo, livre de ambições, ou em cima, na prosperidade, eu e o moleque José teríamos vivido em sossego (IN, p. 31).

Isso não significa que todas as lacunas sejam preenchidas. A obra constitui-se por meio da fragmentação, que é maior em certos momentos, como quando o narrador relembra a violência. O capítulo "Um cinturão" é, nesse sentido, exemplar. $O$ menino apavorado não consegue mover-se ou falar, vive a ameaça do pai como recrudescimento da intensidade e quase anulação da extensidade: "Se o pavor não me segurasse, tentaria escapulir-me [...]. Devo ter pensado nisso, imóvel, atrás dos caixões" (IN, p. 34). Aquilo que foi experimentado como impacto pelo garoto retorna ao campo de presença do narrador, agora como lembrança, mas sem perder a força. A fragmentação textual é a forma encontrada para mostrá-lo aprisionado pela imagem e pelas sensações associadas às horas de horror. É nesses momentos que a memóriaacontecimento aparece em sua integralidade nessa obra. A sequência de orações justapostas e sem ligação, as frases nominais, os substantivos isolados nas frases, o emprego de uma sintaxe da incompletude, as expressões somáticas lançam o acontecimento para o nível da enunciação. Num primeiro momento, o enunciatário não entende com clareza o que se passa, mas pode perceber de forma sensível a raiva experimentada pelo adulto, assim como o medo do menino.

Nesse ponto, torna-se pertinente recuperar a definição proposta por Zilberberg (2006a, p. 233) para o sobrevir, que estabelece uma das maneiras de acesso de uma grandeza ao campo de presença do sujeito, sendo a outra, o pervir. Por corresponder a uma realização súbita do irrealizável, o semioticista afirma que o sobrevir representa uma crise fiduciária radical. Sem qualquer aviso, ele virtualiza as competências modais do sujeito. Nesse caso, observamos que o menino perde a possibilidade de reagir ao pai; o narrador, de certa forma, tem sua voz interrompida; mas também o enunciatário vive momentaneamente uma perda fiduciária ao deparar-se com 0 texto despedaçado, que ele não "consegue" ler num primeiro contato. A obra Infância parece, assim, estar mais próxima dos poemas autobiográficos do que dos memoriais acadêmicos. 
Em Nava, observamos uma situação diferente. Nas obras estudadas do autor - Baú de ossos e Galo-das-trevas -, encontramos muitas passagens em que o narrador revela a sua falta de controle sobre a memória, que sobrevém, no seu presente, como um acontecimento. É o que notamos quando o narrador se lembra de um momento pretérito em que, diante do sobrado da infância, teve seu campo de presença tomado pela reminiscência, como comentamos anteriormente: "[...] tudo, tudo, todos, todos se reencarnando num presente repentino; outra vez palpável, visível, magmático, coeso, espesso e concentrado [...]" (BO, p. 290). Essa passagem dá início ao último capítulo de Baú de ossos, que tem o sobrado como centro da narrativa. Assim todo esse quarto capítulo pode ser compreendido como a "descompressão" do bloco de memória que emerge naquele instante, "rompendo" os níveis do enunciado autobiográfico para atingir o enunciador e o enunciatário. A linguagem poética, dada pela sintaxe "desregrada", pela ênfase em aspectos sensoriais e afetivos e ainda pela exploração do plano da expressão, confere grande aceleração àquelas duas páginas (BO, p. 289-290), que se fazem acontecimento também para o sujeito da enunciação.

Entretanto, geralmente o passado é mostrado em Nava por meio da exaustividade de informações. Vemos isso especialmente nos momentos em que o narrador apresenta uma breve biografia de seus parentes. A história da família mescla-se à do país:

\begin{abstract}
Quando da Proclamação da República seu prestígio subira como foguete. Recebera logo a 15 de novembro um telegrama do Generalíssimo dando conta da queda da Monarquia, ordenando-lhe derrubar a Câmara Municipal, substituí-la por um conselho provisório e que prendesse imediatamente os Barões da Quaresma e do Corregão Velho. Logo o Pareto os meteu no xilindró e por sua própria contra os quais tinha demandas correndo no foro. Logo depois ele fora feito Ministro de Estado mas um mistério envolvia esse fato político. Ficou apenas seis dias à frente de nossas Relações Exteriores, demitiu-se e voltou para Juiz de Fora (GT, p. 153).
\end{abstract}

Há também muitos outros atores biografados, além dos parentes. É o caso de um dos professores de Medicina Legal da época de seu pai, que fez o primeiro ano de Farmácia e o de Medicina na Bahia, antes de mudar-se para o Rio de Janeiro, onde terminou o curso: 
E por falar em Medicina Legal, era também professor da faculdade baiana a essa época, cirurgião de indecorosa história: o Dr. José Pedro de Souza Braga. Nascido a 3 de fevereiro de 1845, formado em 1866, ele foi opositor da seção de cirurgia em 1873, catedrático de Patologia Externa em 1887 e faleceu a 15 de maio de 1898 (BO, p. 90).

O resumo da vida do médico é apresentado antes da narrativa de um "causo", que chegou até mesmo ao conhecimento da imprensa, envolvendo seu casamento malsucedido. Nessa passagem, como em outras, as marcas enunciativas de tempo, espaço e pessoa desaparecem. As datas servem de apoio aos momentos mais marcantes da vida pública do professor. À moda do historiador, o narrador recupera o passado da instituição e de seus membros sem imiscuir-se nele. A ancoragem fornece às informações apresentadas 0 efeito de referência que "garante" a realidade do narrado. O uso predominante do pretérito perfeito 2 confere a essa breve biografia o efeito de acabamento, reforçando inicialmente a distância assumida pelo narrador, devido ao emprego do sistema enuncivo de tempo, espaço e pessoa. $O$ trecho em questão não se mostra então como fruto da atividade da memória, mas como discurso que "copia" o passado tal como foi. Não há expressões somáticas ou qualquer apelo aos sentidos.

Em seguida, o narrador passa a um outro registro para contar o "causo", que, embora tenha vindo a público, faz parte da vida privada do médico. Essa história aparece como fruto da pesquisa realizada pelo narrador de documentos da época, como o jornal Monitor da Bahia, mas também das histórias transmitidas pelo "boca a boca" através das gerações:

Conta-se que o pai da noiva vingou-se primorosamente. Mandou fabricar dois mil grandiosos penicos tendo, ao fundo, o retrato do genro. Esses penicos foram distribuídos por uma população hílare que diariamente cuspia, escarrava, mijava e borrava na beca e na cara do doutor. Mas não se pode deixar de reconhecer o topete do homem que depois de tal escândalo não muda de terra, continua sua carreira clínica e a de professor, impõe-se à população como médico competente e caridoso, aos alunos, como mestre dos mais egrégios (BO, p. 91). 
A presença do narrador não se deixa notar tanto nos dêticos, mas nas avaliações e no tom jocoso que subjaz à narrativa da distribuição dos penicos. De historiador, ele passa a cronista. Parece que, aos poucos, o passado que diz respeito à história das cidades, das instituições brasileiras, dos estados, vai sendo apropriado pelo sujeito. Por fim, ele acaba por apoderar-se daquele universo enuncivo: "Pois meu pai conheceu essa Bahia e esses mestres" (BO, p. 91). A figura do pai e o pronome enunciativo "meu" fazem do passado enuncivo parte da formação do narrador, agora o autobiógrafo. Ele já havia levantado a hipótese de ser talvez "reminiscência baiana" (BO, p. 90) o fato de seu pai ter escolhido fazer sua tese sobre a medicina legal, relacionando assim o incidente do professor às suas opções acadêmicas.

Se, nos memoriais acadêmicos, observamos que o narrador procura criar um distanciamento em relação aos momentos vividos pelo eu do narrado, em Nava encontramos esse movimento feito às avessas. Aquilo que não foi vivido diretamente pelo eu do narrado é tomado pelo narrador - identificado ao enunciador - como experiência que faz parte de sua história, a ponto de, em uma passagem, ele viajar até os tempos de juventude do avô, conforme já mencionamos. Os aspectos sensoriais são destacados, apontando para a possibilidade de a memória tornar presença sensível um passado conhecido por meio dos relatos trocados entre as gerações de uma família:

Somos agora três adolescentes vivendo os banhos salinos que ouvi narrar a Ennes de Souza. Fugas ladeira abaixo até o vindouro de canoas de pesca, a praia idílica e pobre, as gaivotas e as tapenas, nuvens de borboletas caindo nas ondas como flores que despencam, o mar todo crespo, espumoso e aderindo exatamente a cada saliência ou dobra do corpo, amargo ao gosto, ardendo nos olhos do mergulhador. Os peitorais novos em folha empurram-no de encontro ao horizonte (BO, p. 14).

A exaustividade diz respeito também ao modo como a semântica discursiva se constitui na obra de Nava. Se nos instantes de rememoração involuntária, sempre mais raros, o leitor tem acesso inicialmente a certos aspectos do passado, sem conseguir construir sua imagem nítida, não é o que ocorre nos demais momentos de rememoração. Quando o narrador, por meio da lembrança voluntária, passa a enxergar o retrato da mãe de Ennes de 
Souza, cada detalhe da imagem é restituído, oferecendo ao leitor das Memórias uma fotografia verbal do rosto da "matrona". A figuratividade, elaborada por meio de uma exposição minuciosa e por uma linguagem cheia de metáforas e comparações, faz com que a figura se presentifique no texto, apelando para o sensível.

Ignoro o nome da matrona que teve como filhos o neto e seu primo. Mas lembro bem sua figura no quadro a óleo da sala de visitas de Ennes de Souza - que eu seria capaz de repintar de cor. Vejo claramente como se estivesse saindo agora, vivos da moldura oval -0 rosto e o busto meio virados para a esquerda. Vejo o pescoço curto, o porte imperioso da cabeça, os bandos grisalhos realçados pelas rendas pretas da capota de viúva. Os olhos puxados e o olhar perspicaz. $\mathrm{O}$ aquilino brusco do nariz, as maçãs salientes, o queixo forte. $E$ a boca meio funda, entre dois vincos, reta e como que duramente entalhada numa face de pedra. Vejo todos os traços que compunham sua cara quadrada de tapuia já bem diluída e praticamente branca. Vejo o fichu trançado no peito e preso por um camafeu (BO, p. 17).

É possível notar, então, que a obra de Nava parece combinar de maneira conversa a forte intensidade à grande extensidade. $O$ passado, fabricado de maneira detalhada faz-se bastante legível, mas nem por isso é assumido de maneira fraca pelo enunciador. Em cada detalhe fornecido, ele se projeta. Isso também impacta o enunciatário de forma peculiar:

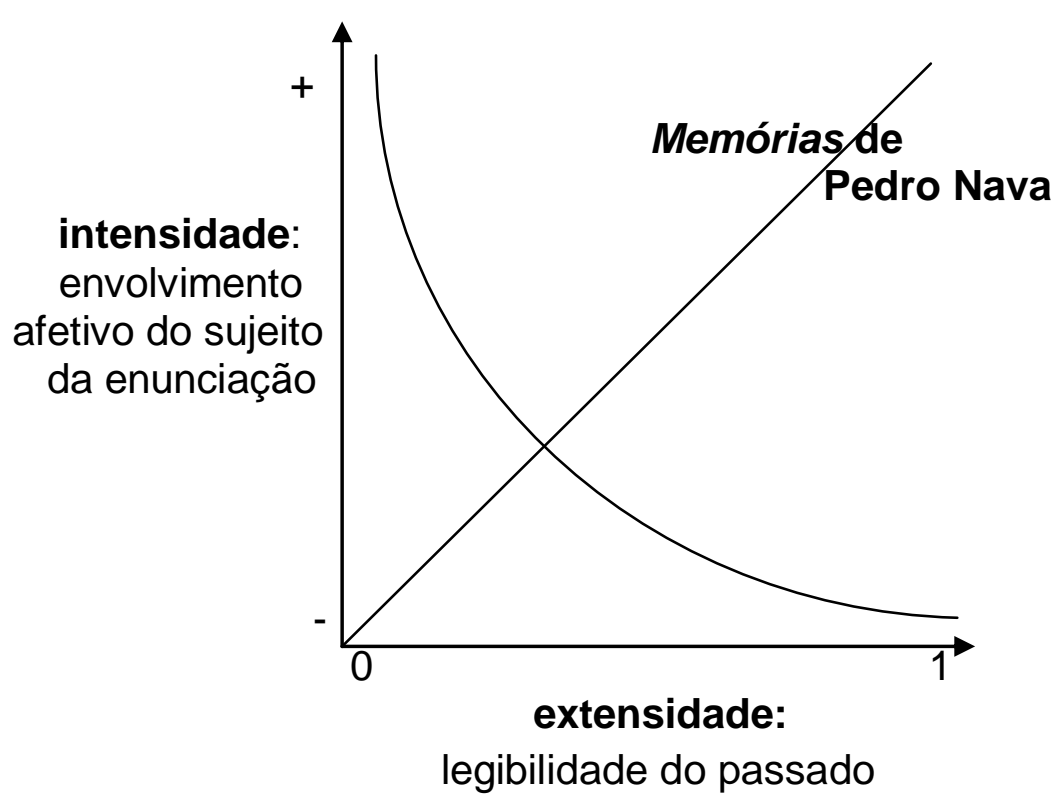


A teoria literária costuma distinguir os gêneros memórias e autobiografia e, geralmente, aponta a obra de Nava como algo que escapa a essa categorização. Isso parece estar ligado, em parte, ao que acabamos de dizer a respeito de Baú de ossos e Galo-das-trevas. Para Lejeune (1971, p. 15), a autobiografia narra a história de uma personalidade, enquanto, nas memórias, o indivíduo é apenas testemunha, seu objeto ultrapassa a vida individual. No mesmo sentido, Gusdorf (1991, p. 260-261) afirma que as memórias privilegiam a relação do sujeito com o mundo e com a história. Geralmente trazem retratos de personalidades importantes, genealogias, descrições das relações sociais. Já a autobiografia apresenta o lado mais privado ou íntimo da vida de um sujeito. Misch (1950, p. 15) também trata dessa questão. Para o autor, nas memórias, a relação entre os sujeitos e o mundo é passiva, já que eles se introduzem, principalmente, como observadores e narradores. Sua participação naquilo que narram é pequena e o que contam sobre sua vida, normalmente, serve apenas para mostrar como se tornaram pessoas notáveis. $\mathrm{Na}$ autobiografia, o centro da história é o eu, problematizado em sua relação com o mundo e consigo mesmo.

Podemos concluir a partir dessas afirmações que as memórias apresentam, geralmente, o percurso de uma figura pública, salientando os aspectos que foram importantes para a obtenção de seu sucesso. Além disso, elas não favorecem o envolvimento afetivo do enunciador, mas a construção de mundo pautada pelo numeroso, no sentido em que exploram de maneira distanciada e abrangente as relações sociais, entre outros elementos. Geralmente, nas memórias, observa-se também grande diversidade de personagens, apresentadas de acordo com os papéis que desempenham na esfera pública. As especulações a respeito do funcionamento da memória ou de problemas ligados à subjetividade recebem menor atenção. A infância também não é enfatizada, pois representa um período em que o sujeito ainda não possui um papel social bem definido. Dessa fase, narram-se quase que somente os pontos relevantes para a explicação direta das vitórias alcançadas no presente. $O$ foco recai sobre a profissão, as relações políticas, a vida de personalidades, a genealogia e tudo o mais que possa servir para valorizar o narrador e o enunciador. 
Já na autobiografia é ressaltada a vida pessoal. Dessa forma, a infância ganha centralidade, assim como os questionamentos a respeito da formação da individualidade, a intimidade, etc. Isso não significa que as relações históricas e sociais sejam deixadas de lado nas obras qualificadas como autobiografias, elas apenas recebem um tratamento diferente daquele dado pelas memórias, pois a ênfase, geralmente, incide sobre o modo específico como sujeito e sociedade entram em contato. Cria-se o efeito de uma história individual e única. $\mathrm{O}$ enunciador seleciona a intensidade das cenas a serem narradas em detrimento da quantidade de referências.

Para herdar essas noções trazidas pelos estudos literários, reconhecemos a possibilidade de concretização da memória no gênero romance autobiográfico, tendendo ora para memórias ora para autobiografia, tal como entendidos pela crítica literária ${ }^{78}$. Gusdorf já chama a atenção para 0 fato de que a tônica na vida individual e a tônica no mundo são dois extremos da literatura autobiográfica, entre os quais se encontram as obras:

O percurso das memórias e aquele da autobiografia não são contraditórios, nem mesmo opostos; eles seriam em princípio concêntricos, o segundo esforçando-se por ficar o mais perto do núcleo do sentido, o primeiro abandonando-se à força centrífuga que projeta sua consciência em expansão de universo" (GUSDORF, 1991, p. 274; tradução nossa) ${ }^{79}$.

A dicotomia se dilui, pois memórias e autobiografia não se opõem, sua diferença é da ordem da gradualidade. Podemos tratá-las como categorias para pensar a prosa literária autobiográfica. As memórias tendem para a memória do acontecido, estão mais perto do gênero institucional, o memorial acadêmico. É o que vemos nas Memórias (1947), de Humberto Campos. Entre os objetivos apontados pelo narrador para contar sua vida, destaca-se:

[...] a demonstração de como pode um homem, pela simples força da sua vontade, desajudado de todos os atributos físicos e morais para a vitória, libertar-se da ignorância absoluta e de defeitos aparentemente

\footnotetext{
${ }^{78} \mathrm{O}$ uso que fazemos do termo "memória" nesta tese é outro.

79 "Le parcours des Mémoires et celui de l'Autobiographie ne sont pas contradictoires, ni même opposés; ils seraient plutôt concentriques, le second s'efforçant de demeurer au plus près du noyau du sens, le premier s'abandonnant à la force centrifuge qui projette la conscience en expansion d'univers"
} 
incorrigíveis, desviando-se dos caminhos que o levariam ao crime e à prisão para outros que poderão conduzir a uma poltrona de Academia e uma cadeira de Parlamento (p. 7-8).

O tom é grandiloquente, a temática distancia-se da vida íntima, as fraquezas, geralmente, são deixadas de lado, a não ser quando, em seguida, é narrada sua superação ${ }^{80}$. O discurso é construído por meio de certa estereotipia, mesmo as paixões são tratadas assim. Destacam-se o orgulho e a autoadulação.

A autobiografia, por sua vez, pode ser pensada como mais próxima da memória-acontecimento, como é o caso de Infância, de Graciliano Ramos, em que se nota a opção pela força, pela intensidade em detrimento do numeroso, da extensidade. Principalmente os momentos de grande impacto são selecionados como matéria de narrativa. No caso da obra de Nava, não nos parece possível afirmar que seja mais autobiografia ou mais memórias, pois tanto dá conta de mostrar a vida a partir do ponto de vista singular do enunciador, como de retratar minuciosamente a sociedade de outros tempos ${ }^{81}$.

\section{CONSIDERAÇÕES FINAIS: A RELAÇÃO ENTRE O ENUNCIADOR E O ENUNCIATÁRIO NO DISCURSO AUTOBIOGRÁFICO}

As noções propostas de memória do acontecido e memóriaacontecimento permitem refletir, no discurso autobiográfico, acerca do contrato enunciativo e, assim, das relações entre enunciador e enunciatário, a partir da tensão que se estabelece entre o sensível e o inteligível. $O$ fato de o texto apresentar-se como autobiográfico, por meio de inúmeros recursos, parece indicar, a princípio, um maior envolvimento afetivo do enunciador. Ele fala do que viveu, o vínculo com o que está dito é então fortalecido simplesmente por

\footnotetext{
${ }^{80}$ Para Antonio Candido (1979), a edição de Memórias de Humberto Campos em 1933 é um marco para o gênero, devido a seu grande sucesso de público. Apesar disso, o crítico qualifica essas memórias como sendo "sinceras e medíocres".

81 "O fato é que as Memórias de Nava aspiram a uma monumentalidade para a qual contribui a intenção premeditada de fazer com sua autobiografia a história de toda uma época, contada nas situações vividas e nos perfis de inumeráveis figuras" (AGUIAR, 1998, p. 30).
} 
tratar-se do discurso autobiográfico. No entanto, para que o efeito desse envolvimento se realize e possa ser reconhecido pelo enunciatário e por ele partilhado sob a forma de empatia, é preciso que o enunciatário reconheça no discurso-enunciado as marcas que fazem com que o texto possa ser considerado autobiográfico. Logo, poderíamos imaginar que o discurso autobiográfico apela sempre e de forma dominante para a afetividade do enunciatário.

Entretanto, não é bem assim. A partir da leitura e análise de inúmeras obras autobiográficas, literárias e acadêmicas, verificamos que seu enunciatário pode ser manipulado por estratégias mais da ordem do sensível (memória-acontecimento) ou mais da ordem do inteligível (memória do acontecido), o que the impõe maneiras também diversas de experienciar 0 texto.

O trabalho estético, mais forte nas obras autobiográficas em que predomina a memória-acontecimento, é uma das estratégias usadas para favorecer o envolvimento sensível e afetivo do sujeito da enunciação. A criação de formas de dizer inovadoras e talvez próprias pode fortalecer o vínculo do enunciador com o discurso, o efeito é de que elas surgem no momento do encontro entre homem e mundo, e não antes disso. Por apresentar-se como um discurso que ressignifica a linguagem, o discurso estético faz ainda com que a ilusão referencial perca a importância em grande parte das obras autobiográficas literárias, especialmente na poesia, pois são criadas outras regras para sua avaliação. A memória do acontecido e a memóriaacontecimento parecem, então, colocar em tensão nas obras autobiográficas dois usos da linguagem, duas racionalidades e ainda duas formas de conhecer e produzir o mundo.

Nas organizações discursivas que chamamos de memóriaacontecimento e memória do acontecido, as interações entre enunciador e enunciatário não são, portanto, iguais. No primeiro caso, a relação privilegia o sensível; enquanto, no segundo, é o inteligível que ganha centralidade. Isso revela que são estabelecidos entre os parceiros da comunicação contratos veridictórios diferentes. Num a verdade é construída essencialmente pelas sensações e emoções; no outro, ela apela mais para o intelecto. 


\section{CONCLUSÃo}

Mas, onde é bobice a qualquer resposta, é aí que a pergunta se pergunta.

João Guimarães Rosa

Grande sertão: veredas

Quando retomamos as análises efetuadas nos capítulos 1, 2 e 3 desta tese, percebemos diferenças no estudo de cada gênero. A escolha da semiótica greimasiana, como base teórica e metodológica desta pesquisa, possibilitou a explicitação das singularidades dos gêneros autobiográficos, pelo exame dos procedimentos específicos usados, por cada um deles, para a construção do sentido.

No momento da análise, o estudioso da linguagem divide, seleciona e hierarquiza, buscando o melhor ângulo de observação do "mundo" já recortado pela própria teoria, o que lhe permite destacar tanto os elementos mais importantes da constituição do objeto quanto aqueles aos quais levam suas indagações e hipóteses. Assim, o efeito de identidade entre enunciador, narrador e protagonista recebeu destaque ao depararmos com Galo-dastrevas, livro que "desarranja" alguns princípios genéricos. Além disso, examinamos, na obra de Pedro Nava, principalmente as relações entre a memória e a estesia, conforme foi tratada por Greimas (2002). Já as relações entre fragmentação e memória, investigadas a partir da noção de acontecimento, foram privilegiadas em Infância, de Graciliano Ramos.

Os modos de existência semiótica permitem tratar de grandezas coocorrentes no discurso segundo os diferentes graus da presença. Pudemos, com isso, mostrar o jogo de fazer aparecer e desaparecer o passado no presente da narração, algo que consideramos central para a produção do sentido nos gêneros autobiográficos e, principalmente, nos poemas de Bandeira. Por fim, chegamos aos memoriais, cuja especificidade é dada pela situação do concurso acadêmico. A noção tensiva de exercício, associada à de estilo e à de éthos direcionaram nosso olhar para os mecanismos responsáveis 
por criar o simulacro de uma vida, até certo ponto, coerente, e ainda a imagem de um enunciador competente para o trabalho acadêmico.

Aproveitamo-nos, então, da "elasticidade" da semiótica, que, sem perder sua vocação para uma teoria geral da significação, permite ao analista realizar inúmeras idas e vindas entre a teoria e o objeto, na busca por adequação e aprendizado. Como ensina Hjelmslev (1975, p. 16), é preciso que haja conformidade entre a teoria e o objeto, sendo o objeto capaz de confirmar ou contrariar a aplicabilidade da teoria. A teoria não pode, portanto, servir de "camisa de força", ela orienta o percurso do estudioso, atribuindo-lhe uma boa parte da competência de que precisa. Enxergamos melhor com ela, assim como a enxergamos também melhor a partir do enfrentamento oferecido pelo objeto, sempre pronto para nos mostrar que tudo poderia ser diferente.

A análise comparativa entre textos de gêneros autobiográficos diversos permitiu investigar, tal como proposto na introdução: a construção das diferentes organizações discursivas da memória, de que emergem interações também diferentes entre enunciador e enunciatário; as relações entre essas interações enunciativas e os gêneros autobiográficos e, ainda, as relações entre tais gêneros e as esferas da comunicação das quais participam.

Os gêneros autobiográficos oferecem simulacros diferentes de "minha vida". Em todos os textos estudados, verificamos que o relato de "minha vida" corresponde à construção de um sentido para essa vida, singularizado em cada texto ou gênero, desde as modulações tensivas, no percurso gerativo do sentido. O "sentido da vida" adquire, então, contornos específicos nos diferentes discursos, delimitando também o que é "falta de sentido" ou "excesso de sentido". No caso dos memoriais, são os picos de tonicidade que parecem ser avaliados como excessivos. A vida é mostrada por meio de uma modulação sem grandes irrupções da intensidade, diferente do que se verificou nos gêneros autobiográficos literários.

A construção desse tipo de percurso revela, nos memoriais, não só a competência do protagonista, geralmente bem sucedido em suas escolhas, mas também do enunciador capaz de oferecer ao enunciatário uma trajetória vista como organizada e direcionada, dentro das coerções genéricas. Logo, o modo como se apresenta o vivido corrobora para a projeção do éthos do enunciador. 
Conforme mostramos, notamos, nos memoriais, uma diferenciação menor de uma obra para outra com relação à configuração do éthos, entendido como efeito de individuação. Nos textos do modelo 1, marcado, entre outros recursos, pela embreagem enunciva do enunciado e da enunciação, o éthos é construído como voz baixa, contida, sem arroubos passionais. Observa-se certa rigidez de corpo, além da frieza e da "neutralidade", efeitos compatíveis com a imagem de professor-pesquisador comprometido com certo tipo de visão da ciência ou dos estudos na área de literatura.

Os exemplares do modelo 2, no qual as embreagens enuncivas de pessoa dão lugar às debreagens enunciativas, revelam um sujeito afetado sensivelmente por seu trabalho e, ainda, um sujeito cujas escolhas profissionais podem ser guiadas também pelo afeto, embora não de forma predominante. As interjeições, as expressões somáticas, a exploração da plasticidade da linguagem, mesmo que não sejam constantes nesses memoriais, fazem-se notar. No lugar do corpo rígido, observa-se um corpo mais maleável, a voz baixa é substituída por algum entusiasmo, e em vez do tom expositivo, marcado pela "neutralidade", encontramos uma postura mais analítica e reflexiva em direção ao passado, ainda que os efeitos de distanciamento e de objetividade sejam, até certo ponto, mantidos.

Há então alguma flexibilização do gênero, se compararmos o modelo 1 ao 2, o que significa que o éthos no modelo 2 deve produzir efeito de maior singularidade em cada texto. Entretanto, se 0 ator da enunciação precisa mostrar que é "único", não pode deixar de enfatizar que corresponde ao que se espera de um professor-pesquisador, adequando-se a certos padrões. É estabelecida uma tensão entre inovação e pertencimento a uma tradição universitária ou científica, que parece impor-se como uma exigência do meio acadêmico.

As diferenças entre os dois modelos de memorial nos levam a concluir que os contratos enunciativos foram parcialmente alterados no meio acadêmico, uma vez que a imagem do professor-pesquisador esperada já não é mais a mesma. Nos dias atuais, parece desejável que o acadêmico se revele como sujeito mais sensibilizado e individualizado. O dever, mais associado aos projetos coletivos, que modaliza o enunciador do modelo 1 - mais frequente na década de 70 na Faculdade de Letras (FFLCH-USP) e nas décadas de 70 e 80 
no Instituto de Biociências (IB-USP) - concorre agora com o querer, mais individual ${ }^{82}$. Podemos ler nessas mudanças aquilo que se costuma qualificar como "ar do tempo" ou ainda como "pós-modernidade"? Tudo indica que sim, embora não seja proposta desta pesquisa desenvolver tal aspecto.

$\mathrm{Na}$ esfera literária, os gêneros são mais flexíveis, o que significa que admitem, no encontro do estilo do gênero, mais coercitivo, com o estilo do autor, mais livre, um leque maior de possibilidades para a projeção do éthos. Isso permite supor que a singularidade nos gêneros autobiográficos literários é buscada com maior vigor. Comparando a obra de Pedro Nava à de Graciliano Ramos, confirmamos essas observações. Em Nava, é como se o enunciador dissesse "eu sou eu porque sou tudo aquilo que me rodeia". Os lugares, os tempos, as pessoas são apresentados com efeito de exaustividade de informação e ainda como extensões do enunciador. Há abundância de adjetivos, enumerações, os períodos expandem-se por mais de uma página, os capítulos são longos; é como se o enunciador evitasse dividir, compartimentar. O corpo é desmedido, o tom de voz parece incorporar diversas possibilidades como o tom ácido, o jocoso, o saudoso, o debochado - e o caráter é moralizante, pois o mundo é dividido, a partir do lugar ocupado pelo enunciador, em "bons" e "maus", e ele se coloca ao lado dos "bons".

É diferente do que vemos em Graciliano Ramos. Embora a análise de apenas uma obra do autor não permita proceder à reconstrução do éthos, ela fornece elementos para verificarmos a flexibilização dos gêneros autobiográficos, quando na esfera literária, e deixa o esboço ou projeção de uma totalidade. Como hipótese, recuperamos uma voz que oscila menos, o tom é mais seco, "enxuto" (uso de frases curtas, menor adjetivação, raridade de interjeições, etc.), compatível com a triagem, que regulamenta o funcionamento de Infância, em seus diversos níveis. O mundo não se divide de forma maniqueísta, o enunciador se mostra um desconfiado.

Outro ponto que usamos para estabelecer as diferentes organizações discursivas da memória e os diferentes contratos enunciativos é a questão do efeito de identidade entre enunciador, narrador e protagonista. Depreendemos os diversos mecanismos sintáticos e semânticos, concernentes ao nível

\footnotetext{
${ }^{82}$ Lembramos que não tivemos acesso a memoriais acadêmicos produzidos antes da década de 70 na Faculdade de Letras ou no Instituto de Biociências.
} 
discursivo, os quais promovem as identidades mencionadas. Tal efeito, já investigado sob outras perspectivas pelos estudiosos que se dedicam a esses gêneros - como Lejeune (1996) e Genette (1991) -, aparece como fundador do discurso autobiográfico. Ao relacionar os diferentes gêneros, percebemos a necessidade de tomá-lo sob o ponto de vista de uma semiótica do contínuo, o que favorece a observação de dessemelhanças mais tênues entre os diversos textos que compõem o corpus desta pesquisa. Foi possível, então, passar do exame da categoria identidade/alteridade, vista de forma discreta, para o exame dos recursos que promovem mais identidade ou menos identidade, ao efetuarem aproximações e distanciamentos entre enunciador, narrador e protagonista.

Apenas para ilustrar, retomamos as relações entre narrador e protagonista. Nos romances autobiográficos, observamos, como um dos procedimentos que contribuem para a manutenção dos contornos que separam essas duas entidades, o uso de sistemas temporais e espaciais distintos para situar o narrador e o protagonista no discurso. Assim, na maior parte dos casos, temos os espaços e tempos enunciativos para o narrador e os espaços e tempos enuncivos para o protagonista. Além disso, os momentos em que a ação da memória é figurativizada por expressões como "eu me lembro de", "nunca esqueci", "sempre me recordo de", entre outras, nota-se o pequeno hiato entre o narrador e o passado. Apesar de dizer "eu", o narrador não é exatamente o mesmo que o protagonista, afinal é capaz de "ver" o protagonista e o mundo que o cercava no passado. No entanto, essas expressões também criam o efeito de que o narrador conta a sua vida (a "minha" vida), ou seja, foi, de certa forma, ele que viveu os eventos narrados num tempo enuncivo; produz-se, assim, a identificação.

Já nos memorais acadêmicos e nos poemas, as expressões que figurativizam a ação da memória escasseiam, mas isso é combinado a outros recursos, o que resulta em efeitos distintos. No caso dos memoriais, a diminuição da frequência com que tais expressões aparecem soma-se a instrumentos discursivos que produzem o efeito de objetividade e de distanciamento. $\mathrm{O}$ eu narrador se torna menos identificado ao eu protagonista, e o rareamento dessas expressões reforça a separação: é enfraquecido o vínculo entre o narrador e o simulacro da vida vivida. Isso torna 
o narrado cada vez mais próximo da ideia de "uma" vida e não de "minha" vida. Nos poemas, ocorre exatamente o contrário. As embreagens temporais e espaciais, substituindo o lá e o então pelo aqui e o agora, as expressões somáticas, a aceleração do conteúdo, entre outros recursos, parecem criar o efeito de que não há diferenças entre o narrador e o protagonista, pois eles vivem e sentem as mesmas coisas em boa parte dos poemas, como se ocupassem o centro do mesmo campo de presença.

É pensando principalmente na relação entre esses três "eus" que podemos falar numa menor compactação nas obras autobiográficas em que predomina a memória do acontecido, do que naquelas em que predomina a memória-acontecimento, pois é como se, nestas, a distinção entre os níveis em que estão o protagonista, o narrador e o enunciador fosse, para o enunciatário, diluída. A compactação somada ao trabalho estético, mais forte nas obras em que prevalece a memória-acontecimento, provoca a surpresa, favorecendo o envolvimento sensível e afetivo do enunciatário. Isso ocorre num primeiro momento, pois a releitura e outros mecanismos de desaceleração podem proporcionar formas diferentes de interação com o texto. Quando impera a memória do acontecido, o enunciatário é levado a aderir ao discurso por meio, principalmente, do inteligível. Ao longo da leitura, ele confirma não apenas as competências do enunciador, mas também as suas próprias, pois é capaz de prever, compreender e reconhecer no texto elementos provenientes de um discurso social no qual se insere.

A partir dessas duas organizações discursivas da memória, pudemos distribuir num gradiente tensivo os diferentes gêneros autobiográficos estudados. Cada gênero tende a favorecer uma combinação específica entre essas duas formas da memória. Assim, verificamos que, nos poemas, a dominância fica, geralmente, por conta da memória-acontecimento. O contrário ocorre com os memoriais acadêmicos nos quais prevalece, na maior parte dos casos, a memória do acontecido. Os romances autobiográficos parecem equilibrar essas duas memórias, como ocorre em Infância, de Graciliano Ramos.

Até agora estamos tratando de uma correlação inversa entre 0 envolvimento afetivo do sujeito da enunciação (intensidade) e a legibilidade da memória (extensidade), sendo que a memória-acontecimento é o encontro da 
intensidade elevada e da extensidade tendendo para a nulidade, enquanto a memória do acontecido resulta da combinação entre a baixa intensidade e a extensidade dilatada. Entretanto, a obra de Pedro Nava surgiu como desafio ao esquema proposto. O passado é elaborado por meio de um detalhamento figurativo. Os elementos trazidos à tona são minuciosamente descritos, por meio da proliferação de adjetivos e locuções adjetivas, que ajudam a torná-los visíveis para o enunciatário. As cenas mostradas ancoram-se, no geral, num tempo e num espaço sociais. Agem nelas atores apresentados por meio da onomástica e cuja descrição desdobra-se em árvores genealógicas, relações familiares e de amizade, dadas a conhecer com um máximo de informações. $\mathrm{Em}$ todos esses elementos, $\mathrm{O}$ enunciador se reconhece e se projeta. $\mathrm{O}$ detalhamento é tamanho, que chega a produzir um efeito poético, renovador de linguagem, o que apela fortemente para a sensibilidade do enunciatário. A obra se constrói, assim, dominantemente por meio de uma correlação conversa entre a intensidade e extensidade: quanto mais da primeira, mais da segunda; quanto menos da primeira, menos da segunda. Trata-se de uma amplificação da memória.

As organizações discursivas da memória indicam, portanto, que há contratos enunciativos diferentes em cada gênero autobiográfico. Não se trata de diferenças que dizem respeito à oposição que normalmente se faz entre "realidade" e "ficção", como dissemos no início do trabalho, mas de interações diferentes entre enunciador e enunciatário. Conforme apontado, na memória do acontecido, propõe-se que o enunciatário se aproxime do texto pelo viés da inteligibilidade. $O$ enunciador oferece uma forma de construir o mundo que cria o efeito do conhecido, o que gera conforto. Na memória-acontecimento, é estabelecido um contrato baseado nos afetos e nas sensações. O enunciatário é "capturado" por meio do susto, do impacto. Procuramos mostrar também que essas relações entre os parceiros da comunicação não são estanques, pois as diferentes organizações discursivas da memória convivem em cada gênero, o que nos autoriza a falar apenas em dominância. Ressaltamos que é justamente a tensão entre essas duas memórias que parece ser fundadora dos gêneros autobiográficos. Naqueles que circulam na esfera literária, predominam os contratos estéticos e passionais; enquanto nos que fazem parte da esfera acadêmica prevalecem os contratos mais fortemente baseados no inteligível. 
Todas essas configurações da memória são responsáveis por fazer o passado lembrado materializar-se diante do sujeito da enunciação. Retomando os modos da existência semiótica, podemos dizer que a escritura autobiográfica realiza ou atualiza o vivido. Disso decorre que os memoriais acadêmicos, os quatro poemas de Bandeira, as Memórias, de Pedro Nava, e Infância, de Graciliano Ramos, podem ser compreendidos como obras que efetuam uma macroembreagem temporal: o passado é presentificado. Elas trazem para o agora da enunciação um simulacro, uma imagem de um então. Daí poderem ser chamadas discurso da memória, pois segundo Santo Agostinho, a memória é o presente do passado; podemos dizer ainda que ela é o passado no presente:

O que agora me aparece como uma coisa líquida e certa é que nem o futuro nem o passado são. Por isso, diz-se de maneira imprópria que os tempos são três, o pretérito, o presente e o futuro. Dir-se-ia de maneira muito mais própria: os tempos são três, o presente do pretérito, o presente do presente e o presente do futuro. Esses últimos estão em nosso espírito e não os vejo em outro lugar. O presente das coisas passadas é a memória, o presente das coisas presentes é o olhar, 0 presente das coisas futuras é a espera (AGOSTINHO, 2001, XX, 26).

A escritura autobiográfica presentifica o passado, mas será que poderíamos ir ainda mais longe e encontrar nela as marcas que a tornam uma antecipação do futuro?

[...] o texto autobiográfico instaura uma dupla relação: em retrospectiva, a relação entre o escritor e seu passado; em prospectiva, a relação entre o escritor e um futuro confundido com a circulação do produto texto (PARRET, 1988, p. 28-29; tradução nossa) ${ }^{83}$.

Toda obra carrega a expectativa do encontro com seu leitor, que comporá, com as páginas lidas, a sua própria memória. É nesse sentido que podemos falar também da memória na linguagem, ou da escritura autobiográfica, não apenas como ponto de chegada, mas de partida, o início de novas lembranças.

83 [...] le texte autobiographique instaure une double relation: en rétrospective, la relation entre le scripteur et son passé; en prospective, la relation entre le scripteur et un avenir confondu avec la circulation du produit-texte". 


\section{BIBLIOGRAFIA}

AGOSTINHO (2001). Confissões. Tradução de Arnaldo do Espírito Santo et alli. Lisboa, Centro de Literatura e Cultura Portuguesa e Brasileira/ Imprensa Nacional/ Casa da Moeda.

AGUIAR, Joaquim Alves de (1998). Espaços da memória. Um estudo sobre Pedro Nava. São Paulo: Edusp.

ALENCAR, José de (1955). Como e por que sou romancista. Salvador: Progresso.

ANDRADE, Eugénio de (1977). Versos e alguma prosa de Luís de Camões. Lisboa: Fundação Calouste Gulbenkian.

ANGYALOSSY, Veronica (2006). Memorial. (Memorial apresentado no concurso de Livre-Docência junto ao Departamento de Botânica) Instituto de Biociências da Universidade de São Paulo, São Paulo.

ANJOS, Cyro dos (1994). A menina do sobrado. Rio de Janeiro/Belo Horizonte: Livraria Garnier.

ARRIGUCCI Jr, Davi (1987). "Móbile da memória". In: Enigma e comentário. São Paulo: Companhia das Letras, p. 67-111.

(1990a). Memorial. (Memorial apresentado no concurso de LivreDocência junto ao Departamento de Teoria Literária) Faculdade de Filosofia, letras e Ciências Humanas da Universidade de Sâo Paulo, São Paulo.

(1990b). Humildade, paixão e morte. A poesia de Manuel Bandeira. São Paulo: Companhia das Letras.

ASSIS, Machado (2008) Obra completa. Rio de Janeiro: Editora Nova Aguilar, v. 2.

AUGÉ, Marc. Les formes de l'oubli. Paris: Éditions Payot et Rivages, 2001.

AUTHIEZ-REVUZ, Jacqueline (1982). Hétérogénéité montrée et hétérogénéité constitutive: eléments pour une approche de l'autre dans le discours. Drlav 26. Paris: Centre de Recherche de l'Université de Paris VIII, p. 91-151.

BAKHTIN, Mikhail (1998). Questões de literatura e estética: a teoria do romance. Tradução de Aurora Fornoni Bernardini et alii. São Paulo: Hucitec.

(2006). Estética da criação verbal. São Paulo: Martins Fontes. 
BANDEIRA, Manuel (org.) (1946). Antologia de poetas brasileiros bissextos contemporâneos. Rio de Janeiro: Zelio Valverde.

(1966). Andorinha, andorinha. Rio de Janeiro: José Olympio.

(1984) Itinerário de Pasárgada. Rio de Janeiro: Nova Fronteira.

(1993) Estrela da vida inteira. Rio de Janeiro: Nova Fronteira.

BARTHES, Roland (1987). Elementos de semiologia. Tradução de Izidoro Blikstein. São Paulo: Cultrix.

BARROS, Diana Luz Pessoa de (1989/1990). Paixões e apaixonados: exame semiótico de alguns percursos. Cruzeiro Semiótico. Porto: Associação Portuguesa de Semiótica, 11-12: 60-73.

Humanitas.

(2002). Teoria do discurso. Fundamentos semióticos. São Paulo:

BARROS, Manoel de (2007). Memórias inventadas. A segunda infância. São Paulo: Planeta.

(2008). Memórias inventadas. A terceira infância. São Paulo: Planeta.

BARROS, Mariana Luz Pessoa de (2006). A arquitetura das memórias: um estudo do tempo no discurso autobiográfico. (Dissertação de Mestrado em Semiótica e Linguística Geral) Faculdade de Filosofia, Letras e Ciências Humanas, Universidade de São Paulo, São Paulo.

BEIVIDAS, Waldir; RAVANELLO, Tiago (2006). "Reflexões sobre o discurso: a linguagem como re-criação do mundo". In: LARA, Glaucia Muniz Proença. Língua(gem), texto, discurso. Entre a reflexão e a prática. Rio de Janeiro/Belo Horizonte: Lucerna/FALE/UFMG, p. 117-135.

BENVENISTE, Emile (1966). Problémes de linguistique générale. Paris: Gallimard, vol. 1.

BERGSON, Henri (2006a). Matéria e memória. Ensaio sobre a relação do corpo com o espírito. Tradução de Paulo Neves. São Paulo: Martins Fontes.

(2006b). Memória e vida. Textos escolhidos por Gilles Deleuze. Tradução de Claudia Berliner. Textos escolhidos. São Paulo: Martins Fontes.

BERTRAND, Denis (2003a). Caminhos da semiótica literária. Tradução do Grupo Casa. Bauru: Editora da Universidade do Sagrado Coração.

(2003b). L'extraction du sens. Instances énonciatives et figuration de l'indicible. Versants. Revue suisse des littératures romanes. Genebra: Éditions Slatkine, no double spécial 44-45, p. 317-332. 
BORBA, Francisco de Silva (2002). Dicionário de usos do português do Brasil. São Paulo: Ática.

BORGES, Jorge Luis (1999). Obras completas. Tradução de Jorge Schwartz et alii. São Paulo: Editores Globo, v. 1.

BOSI, Ecléa (2001). Memória e sociedade. Lembranças de velhos. São Paulo: Companhia das Letras.

CÂMARA, Sandra Cristinne Xavier; PASSEGGI, Maria da Conceição (2008). Memorial acadêmico: investigando sua gênese. In: PASSEGGI, Maria da Conceição; BARBOSA, Tatyana Mabel Nobre (orgs.). Memórias, memoriais: pesquisa e formação docente. Natal/São Paulo: Editora da UFRN/Paulus.

CAMPOS, Humberto (1947). Memórias. Rio de Janeiro: W. M. Jackson.

CANDIDO, Antonio CANDIDO, Antonio (1974). Memorial (Memorial apresentado ao concurso para provimento de um cargo de Professor Titular no Departamento de Linguística e Línguas Orientais) Faculdade de Filosofia, letras e Ciências Humanas da Universidade de São Paulo, São Paulo.

(1979). A literatura brasileira em 1972. Arte em revista. São Paulo: Kairós, n.1, p. 20-26.

(1992). Ficção e confissão. Ensaios sobre Graciliano Ramos. Rio de Janeiro: Editora 34.

CARVALHO, Paulo César de (2005). Fragmentos epistolares de um discurso amoroso: elementos para uma análise semiótica do estatuto do gênero carta de amor. (Dissertação de mestrado) Faculdade de Filosofia, Letras e Ciências Humanas, Universidade de São Paulo, São Paulo.

CASTELO, José Aderaldo (1999). A literatura brasileira. Origens e unidade. São Paulo: Edusp, v. 2.

CASTRUCCI, Ana Maria de Lauro (1992). Memorial. (Memorial apresentado ao concurso para provimento de um cargo de Professor Titular no Departamento de Fisiologia Geral) Instituto de Biociências da Universidade de São Paulo, São Paulo.

DAHLET, Véronique Maria Braun (2004). Memorial. (Memorial apresentado no concurso de Livre-Docência junto ao Departamento de Letras Modernas) Faculdade de Filosofia, Letras e Ciências Humanas da Universidade de São Paulo, São Paulo.

DEUS, João de (1990). Campo de flores. Lisboa: Publicações Europa-América.

DIAS, Gonçalves (1926). Poesias. Rio de Janeiro/Paris: Livraria Garnier. 
DISCINI, Norma (2002). Memorial. (Memorial apresentado no concurso para provimento de um cargo de Professor Doutor no Departamento de Linguística) Faculdade de Filosofia, Letras e Ciências Humanas da Universidade de São Paulo, São Paulo.

(2003). O estilo nos textos. São Paulo: Contexto.

(2009). Semiótica: da imanência à transcendência (questões sobre estilo). Revista Alfa. São Paulo: UNESP, v. 53, n. 2, p. 595-617.

(2010). Da presença sensível. CASA. Cadernos de Semiótica Aplicada. Araraquara: UNESP, v.8, n.2.

DURAS, Marguerite (1984). L'amant. Paris: Les Éditions de Minuit.

FÁVERO, Afonso Henrique. (1999). Aspectos do memorialismo brasileiro. (Tese de doutorado em Literatura Brasileira) Faculdade de Filosofia, Letras e Ciências Humanas, Universidade de São Paulo, São Paulo.

FIORIN, José Luiz (1994). Memorial. (Memorial apresentado no concurso de Livre-Docência junto ao Departamento de Linguística) Faculdade de Filosofia, Letras e Ciências Humanas da Universidade de São Paulo, São Paulo.

(1996). As astúcias da enunciação. São Paulo: Ática.

(1998). Linguagem e ideologia. São Paulo: Ática.

(2005a). "Gêneros e tipos textuais". In: MARI, Ugo; WALTY, Ivete e VERSIANI, Zélia (orgs.). Ensaios sobre leitura. Belo Horizonte: Editora PucMinas, p. 101-117.

(2006). Introdução ao pensamento de Bakhtin. São Paulo: Ática.

(2007a). Paixões, afetos, emoções, sentimentos. CASA. Cadernos de Semiótica Aplicada. Araraquara: UNESP, v. 5, p. 1-15.

(2007b). Semiótica das paixões: o ressentimento. Alfa: Revista de Linguística. São Paulo: UNESP, v. 51, n. 1, p. 9-22.

(2008). Em busca do sentido. Estudos discursivos. São Paulo: Contexto.

FONTANIER, Pierre (1988). Les figures du discours. Paris: Flammarion.

FONTANILLE, Jacques; ZILBERBERG, Claude (2001). Tensão e Significação.

Tradução de Ivã Carlos Lopes, Luiz Tatit e Waldir Beividas. São Paulo: Discurso Editorial/Humanitas. 
GALLE, Helmut; OLMOS, Ana Cecília; (2009). "Apresentação". In: GALLE, Helmut; OLMOS, Ana Cecília; KANZEPOLSKY, Adriana; IZARRA, Laura Zuntini (orgs.). Em primeira pessoa. Abordagens de uma teoria da autobiografia. São Paulo: Annablume.

GENETTE, Gerard (1991). Fiction et diction. Paris: Seuil.

GENINASCA, Jacques (1997). La parole littéraire. Paris: PUF.

GREIMAS, Algirdas Julien (1970). Du sens. Paris: Seuil. (1983). Du sens II. Paris: Seuil.

(1986). De la nostalgie. Actes sémiotiques. Bulletin, 39.

(2002). Da imperfeição. São Paulo: Hacker.

; COURTÉS, Joseph (2008). Dicionário de Semiótica. Tradução de Alceu Dias Lima et alii. São Paulo: Cultrix.

; FONTANILLE, Jacques (1993). Semiótica das paixões. Tradução de Maria José Rodrigues Coracini. São Paulo: Editora Ática.

GUSDORF, Georges (1991). Les écritures du moi. Paris: Garnier.

HAJJI-LAHRIMI, Laïla El (1999). Sémiotique de la perception dans À la recherche du temps perdu de Marcel Proust. Paris: L Harmattan.

HJELMSLEV, Louis (1975). Prolegômenos a uma teoria da linguagem. Tradução de José Teixeira Coelho Netto. São Paulo: Perspectiva.

HOUAISS, Antônio (2009). Dicionário Houaiss da língua portuguesa. Rio de Janeiro: Editora Objetiva.

ILARI, Rodolfo (1996). Memorial. (Memorial apresentado ao concurso para provimento de um cargo de Professor Titular no Departamento de Linguística) Instituto de Estudos da Linguagem da Universidade Estadual de Campinas, Campinas.

IMPERATRIZ-FONSECA (1992). Memorial. (Memorial apresentado ao concurso para provimento de um cargo de Professor Titular no Departamento de Ecologia Geral) Instituto de Biociências da Universidade de São Paulo, São Paulo.

JAKOBSON, Roman (1963). "Deux aspects du langage et deux types d'aphasies". In: Essais de linguistique general. Paris: Les Éditions de Minuit.

(1995). Linguística e comunicação. Tradução de Izidoro Blikstein e José Paulo Paes. São Paulo: Cultrix. 
LAFETÁ, João Luiz (1999). Memorial acadêmico. In: Homenagem a João Luiz Lafetá. São Paulo: Nova Alexandria, p. 13-40.

LANDOWSKI, Éric (2005). Les interactions risquées. Nouveaux Actes Sémiotiques. Limoges, Pulim, n. 101-102-103.

LEJEUNE, Philippe (1971). L'autobiographie en France. Paris: Armand Colin. (1996). Le pacte autobiographique. Paris: Seuil. (2005). Sgnes de vie. Le pacte autobiographique 2. Paris: Seuil.

MAGALHÃES, Luiz Edmundo de (1978). Memorial. (Memorial apresentado no concurso de Professor Adjunto no Departamento de Biologia) Instituto de Biociências da Universidade de São Paulo, São Paulo.

MAINGUENEAU, Dominique (2005). "Ethos, cenografia, incorporação". In: AMOSSY, Ruth (org.). Imagens de si no discurso: a construção do ethos. São Paulo: Contexto, p. 69-92.

MATIOLI, Sergio Russo (2001). Memorial. (Memorial apresentado no concurso de Livre-Docência junto ao Departamento de Biologia) Instituto de Biociências da Universidade de São Paulo, São Paulo.

MELO, Mário (1958). "O busto e o modêlo". Jornal do Commercio. Recife, 12 mar. Crônica da cidade. Disponível em: http://www.cafecolombo.com.br/ Acesso em 28 abr. 2011.

MEYER, Augusto (1949). Segredos de infância. Porto Alegre: Editora Globo.

MISCH, Georg (1950). A History of Autobiography in Antiquity. Londres: Routledge.

MOISÉS, Massaud (1974). Dicionário de termos literários. São Paulo: Cultrix. MOLLOY, Sylvia (1996). Acto de presencia. La escrita autobiográfica en hispanoamerica. México: El Colegio de México/ Fondo de Cultura Económica.

MOREIRA, Plinios Soares (1971). Memorial. (Memorial apresentado no concurso de Livre-Docência junto ao Departamento de Fisiologia Geral) Instituto de Biociências da Universidade de São Paulo, São Paulo.

NAVA, Pedro (2000). Baú de ossos. São Paulo: Ateliê.

(2000). Balão cativo. São Paulo: Ateliê.

(2001). Chão de ferro. São Paulo: Ateliê.

(2003) Beira-mar. São Paulo: Ateliê. 
(2003) Galo-das-trevas. São Paulo: Ateliê.

(2004) O círio perfeito. São Paulo: Ateliê.

(2006) Cera das almas. São Paulo: Ateliê.

NEGRÃO, Esmeralda (2004). Memorial. (Memorial apresentado ao concurso para provimento de um cargo de Professor Titular no Departamento de Linguística) Faculdade de Filosofia, Letras e Ciências Humanas da Universidade de São Paulo, São Paulo.

NEVES, Walter (2007). Memorial (Memorial apresentado ao concurso para provimento de um cargo de Professor Titular no Departamento de Genética e Biologia Evolutiva) Instituto de Biociências da Universidade de São Paulo, São Paulo.

PARDINI, Renata (2007). Memorial. (Memorial apresentado no concurso para provimento de um cargo de Professor Doutor no Departamento de Zoologia) Instituto de Biociências da Universidade de São Paulo, São Paulo.

PARRET, Herman (1988). Le sublime du quotidien. Paris-AmesterdamPhiladelphia: Hadès- Benjamins

(2006). Sutures sémiotiques. Limoges: Editions Lambert-Lucas.

PETTER, Margarida Maria Taddoni (2008). Memorial. (Memorial apresentado no concurso de Livre-Docência junto ao Departamento de Linguística) Faculdade de Filosofia, Letras e Ciências Humanas da Universidade de São Paulo, São Paulo.

POMPÊO, Marcelo Luiz Martins (2007). Memorial. (Memorial apresentado em concurso junto ao Departamento de Ecologia) Instituto de Biociências da Universidade de São Paulo, São Paulo.

POSSENTI, Sírio (1994). Memorial. (Memorial apresentado no concurso de Livre-Docência junto ao Departamento de Linguística) Instituto de Estudos da Linguagem da Universidade Estadual de Campinas, Campinas.

QUADROS, Marli (2006). Memorial. (Memorial apresentado no concurso de Livre-Docência junto ao Departamento de Letras Clássicas e Vernáculas) Faculdade de Filosofia, Letras e Ciências Humanas da Universidade de São Paulo, São Paulo.

RAMOS, Graciliano (2003). Infância. Rio de Janeiro/São Paulo: Record. (2008). Memórias do cárcere. Rio de Janeiro/São Paulo: Record.

REGO, José Lins do (1987). Ficção completa. Rio de Janeiro: José Olympio, v. 2. 
RICOEUR, Paul (2003). La mémoire saisie par l'histoire. Revista de Letras. São Paulo: UNESP, v. 2, n. 43, p. 15-25.

RODRIGUES, Miguel Trefaut Urbano (1996). Memorial (Memorial apresentado ao concurso para provimento de um cargo de Professor Titular no Departamento de Zoologia) Instituto de Biociências da Universidade de São Paulo, São Paulo.

ROSA, Guimarães (2005). Grande sertão: veredas. Rio de Janeiro: Nova Fronteira.

ROSENBAUM, Yudith (1993). Manuel Bandeira: uma Poesia da Ausência. Rio de Janeiro/São Paulo: Imago/EDUSP.

ROUSSEAU, Jean-Jacques (1933). Les confessions de Jean-Jacques Rousseau. Paris: Pleiade.

SANCHES NETO, Miguel (2000). Chove sobre a minha infância. Rio de Janeiro: Record.

SAUSSURE, Ferdinand (1969). Curso de linguística geral. Tradução de Antônio Chelini et alii. São Paulo: Cultrix/Edusp.

SAVIETTO, Maria do Carmo (2002). O intertexto proustiano nas memórias de Pedro Nava. São Paulo: Nankin.

SINGER, Paul (1968). Desenvolvimento econômico e evolução urbana. São Paulo: Companhia Editorial Nacional/ Editora da Universidade de São Paulo.

STAROBINSKI, Jean (1970). Le style de l'autobiographie. Poétique. Paris: Seuil, v. 3, p. 257-265.

TATIT, Luiz (2001). Análise semiótica através das letras. São Paulo: Ateliê. (2002). Memorial. (Memorial apresentado ao concurso para provimento de um cargo de Professor Titular no Departamento de Linguística) Faculdade de Filosofia, Letras e Ciências Humanas da Universidade de São Paulo, São Paulo.

(2010). Semiótica à luz de Guimarães Rosa. São Paulo: Ateliê.

TEZZA, Cristovão (2003). Entre a Prosa e a Poesia: Bakhtin e o Formalismo Russo. Rio de Janeiro: Rocco.

TODOROV, Tzvetan (1981). Os gêneros do discurso. Tradução de Ana Mafalda Leite Lisboa: Edições 70. 
URSI, Suzana (2007). Memorial. (Memorial apresentado no concurso para provimento de um cargo de Professor Doutor no Departamento de Botânica) Instituto de Biociências da Universidade de São Paulo, São Paulo.

VIEIRA, Antonio (2003). Sermões. São Paulo: Hedra.

VOLOCHINOV. Valentin. (1976). Discourse in Life and Discurse in Art (Concerning Sociological Poetics). In: Freudianism. A marxiste critique. Tradução de I. R. Titunik. New York: Academic Press, p. 93-116.

ZILBERBERG, Claude (2004). As condições semióticas da mestiçagem. In: CAÑIZAL, Eduardo; CAETANO, Kati Eliana (orgs.). O olhar à deriva: mídia, significação e cultura. São Paulo: Annablume, p. 69-102.

(2006a) Eléments de grammaire tensive. Limoges, Pulim.

(2006b). Síntese da gramática tensiva. Significação. Tradução de Ivã

Carlos Lopes e Luiz Tatit. Revista brasileira de semiótica. São Paulo: Annablume, n. 25, p. 163-204.

(2007a). De la consistance. Disponível em: http://www.claudezilberberg.net Acesso em: 28 jul. 2008.

(2007b) Louvando o acontecimento. Tradução de Maria Lucia Vissotto Paiva Diniz. Revista Galáxia. São Paulo: n. 13, p.13-28, jun. 
Ilustrações: Flávia Lobo de Felício 